LA-6652-MS

informal Roport

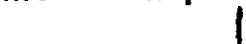

Special Distribution

Issued: Mor 1977

\title{
Uranium Hydrogeochemical and Stream Sediment Reconnaissance in Lincoln and Flathead Counties, Northwest Montana
}

by

Paul L. Aamodt

NOTICE

PORTIONS OF THIS REPORT ARB ILCEOTBLE. It has boen reproduced from the best avallable copy to pormit the braadest possible avallatil1ty.

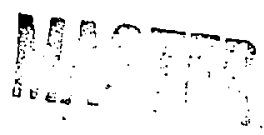


Thle work uns supported by the OS Eanrg Research and Developeat Adedolezration. Divieloe of Urantil Recourcall end Enrtehment. Pragre Cods sosb.

Th1s report was preparad as an account of work sponsored by the Ontted States Govermant. Neither the Daited States dor the United States Enorgy Resenrcb and Development Adatolstration, wor any of thats exployeas, nor any of their coneractors, aubcoutractors, or tbalr employen, ankes any urranty, exprean or Implied, or esaumas any legel liability or rasponstbility for the accuracy, corpleteness, or ugafuldese of any informetion, apparatue, product, or process dieclosed, or represents that 1ts wee would got infrigge privately owned righte. 
LIST OF ILLUSTRATIONS v v

LIST OF TABLES V1

ABSTRACT 1

I. INTRODUCTION 2

Field Sampling 2

Sample Analysis 4

II. GEOGRAPHIC SETTING 4

Climate $\quad 5$

III. HYDFOLOGY 6

IV. GEOLOGY 8

Igneous Rocks in the Area 11

Structural Setting $\quad 12$

Mineral Occurrences in the Area $\quad 12$

Uranium Occurrences in the Area 16

v. GEOCHEMICAL NATURE OF URANIUM 17

VI. STATISTICAL AND EMPIRICAL EVALIIATION OF THE WATER DATA

VII. STATISTICAL AND EMPIRICAL EVALUATION OF THE $\begin{array}{ll}\text { SEDIMENT DATA . } & 25\end{array}$

VIII. SUMMARY AND CONCLUSIONS 33

$\begin{array}{ll}\text { ACKNOWLEDGMENTS } & 36\end{array}$

$\begin{array}{ll}\text { REFERENCES } & 37\end{array}$

APPENDIX A - Summary of Standard Procedures used by the LASL in the US ENDA National Uranium Resource Evaluation Hydrogeochemical and Stream Sediment Reconnaissance

APPENDIX B - Histograms of Uranium Concentrations in: Water and Sediment Samples from Lincoln and Flathead Counties, Northwest Montana

B-I - Raw Data and Log Data Histograms for Uranium in Hater

B-II - Raw Data and Log Data Histograms for Uranium in Sediment 


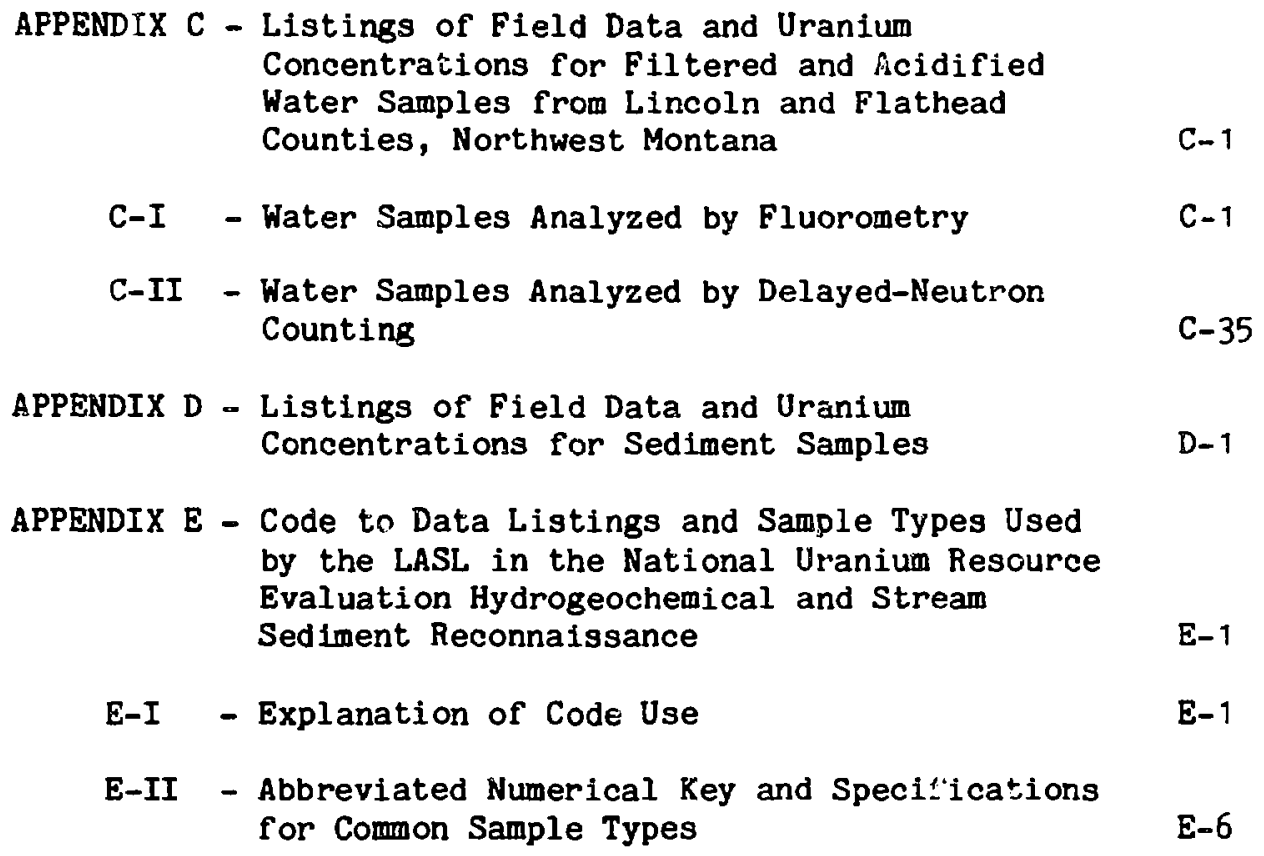


Fig. No.

1. Location of northwest Montana reconnaissance survey area.

2. Major rivers and mountain ranges in northwest Montana.

3. Simplified correlation of Precambrian sedimentary units in northwestern Montana with yost-Precambrian stratigraphy in northwest Flathead County.

4. Tectonic nap--northwest Montana.

5. Mining districts and mineral deposits--northwest Montana.

Plate No.

I. Generalized geology (parts of Lincoln and Flathead Counties), northwest Montana.

Pocket

II. Water and sediment sample locations in Lincoln and Flathead Counties, northwest Montana.

Pocket

III. Graphic plot of uranium concentrations in water samples from Lincoln and Flathead Counties, northwest Montana (overlay).

Pocket

IV. Graphic plot of uranium concentrations in sediment samples from Lincoln and Flathead Counties, northwest Montana (overlay).

Pocket 
Table No.

I. AVERAGE ANNUAL TEMPERATURE AND PRECIPITATION AT SELECTED WEATHER STATIONS IN NORTHWEST MONTANA

FOR THE YEARS 1970-1975

II. SUMMARY OF AVERAGE MONTHLY TEMPERATURE AND

PRECIPITATION AT SELECTED WEATHER STATIONS IN

NORTHWEST MONTANA FOR THE MONTHS OF MAY AND

JUNE 1976

7

III. SUMMARY DESCRIPTIONS OF MAJOR MINING DISTRICTS

IN LINCOLN AND FLATHEAD COUNTIES, NORTHWEST MONTANA

IV. SUMMARY OF URANIUM DATA FOR FILTERED AND ACIDIFIED WATER SAMPLES COLLECTED IN NORTHWEST MONTANA

V. SUMMARY OF URANIUM DATA FOR SEDIMENT SAMPLES

COLLECTED IN NORTHWEST MONTANA

VI. LOCATION NUMBERS AND RELEVANT DATA FOR ISOLATED HIGH AND/OR ANOMALOUS SEDIMENT SAMPLES, NORTHWESTERN MONTANA 
URANIUM HYDROGEOCHEMICAL AND STREAM SEDIMENT RECONNAISSANCE

IN LINCOLN AND FLATHEAD COUNTIES, NORTHWEST MONTANA

by

Paul L. Aamodt

\section{ABSTAACT}

Between mid-May and late June 1976, 3409 water and water-transported sediment gamples were collected from 1781 locations spread over an approximate $17,000-\mathrm{km}^{2}$ area of northwestern Montana. All of the samples were analyzed for total uranium at the LASL, using standardized procedures and rigorous quality controls--the waters by fluorometry and the sediment (and those waters with $>10 \mathrm{ppb}$ uranium) by delayed-neutron counting methods. The 1684 water samples were collected from five sources, including 1582 streams, 44 natural ponds, 41 springs, 14 artificial ponds, and 3 wells. Of the 1725 sediment samples, 1542 were from active streams, 87 were from dry streams, 41 from wet natural ponds, 38 from flowing springs, 14 from wet artificial ponds, and 3 from other sources. All of the field collection, treatment, and packaging of the samples was performed following strict LASL specifications. The uranium concentrations measured in the waters range from undetectable $(<0.2) \mathrm{ppb}$ to $173.6 \mathrm{ppb}$, but average only $0.66 \mathrm{ppb}$. The low uranium concentrations in the waters of this area are thought to be due primarily to a general lack of readily soluble uranium and dilution with spring runoff. Those locations which did have abnormally high uranium were examined more closely, and follow-up rield examinations are recomended in the vicinity of some of these sites. The uranium content of the sediment samples range from $0.5 \mathrm{ppm}$ to 52.2 $\mathrm{ppm}$ and average $4.56 \mathrm{ppm}$. Sample locations with high and/or anomalous uranium values were examined with respect to the local geology, water chemistry, and other relevant factors. A distinct correlation between the high uranium in sediment and epithermal and mesothermal veins associated with nearby faults and folds is evident at several locations. Areas believed to be favorable for follow-up field investigations based on the sediment data are indicated. A correlation between high uranium in water and high uranium in sediment is evident at only a single location, that of a flowing spring. The generally low uranium concentrations in water and moderate concentrations in sediment seem to indicate that most of the uranium that does exist in this area is bound up in resistant minerals. 


\section{INTRODUCTION}

This report describes work done by the Los Alamos Scientific Laboratory (LASL) for the Energy Research and Development Administration (ERDA). The ERDA Grand Junction, Colorado, Office (GJO) is responsible for administering a nationwide Hydrogeochemical and Stream Sediment Reconnaissance (HSSR) as part of their National Uranium Resource Evaluation (NURE) program. The HSSR is designed to identify areas within the continental United States and Alaska having higher than normal concentrations of uranium in surface water, groundwater and waterborne sediment. By identifying such areas, the HSSR will aid in the overall assessment of the nation's energy resources, and in addition, it can provide guidance to the private sector for selecting promising areas for future uranium exploration.

The LASL is responsible for completing the HSSR program throughout the Rocky Mountain states of New Mexico, Colorado, Wyoming, and Montana and the state of Alaska. This report covers an area of approximately $17000 \mathrm{~km}^{2}$ in extreme northwestern Montana, which is generally bounded by latitude $48^{\circ}$ north on the south, the Canadian border on the north, the Idaho state line on the west, and the western boundary of Glacier National Park and longitude $113^{\circ} 30^{\prime}$ on the east. Fig. 1 shows the location of the survey area and the b.undaries of the three 1:250 000-scale National Topographic Map Sories (NTMS) sheets which, taken together, cover 1t. Plate I, in the rear pocket, is a geologic base map of the area and is provided for use in evaluating the reported data in relation to the local geology. The appropriate NTMS sheets (Sandpoint, Kalispell, and Cut Bank) can be used in conjunction with the translucent overlays, Plates II, III, and IV (also at a scale of 1:250 000), in the rear pocket, as base maps for identifying drainages, access, relief, etc., in the report area. A few locations sampled near, but just outside, the study area are included to provide overlap and a basis for comparison with areas to be surveyed later. Although this area is not noted for uranium mineralization, its geologic similarity to uraniferous areas farther west (around Spokane, Washington) was considered when selecting it for this survey.

\section{Field Sampling}

During the period from May 18 to June 26, 1976, 1781 locations Ehroughout the northwestern Montana study area were sampled for water and/or water transported sediment by field personnel employed by a commercial firm under contract to the LASL. The sample locations, sample treatments, and field 


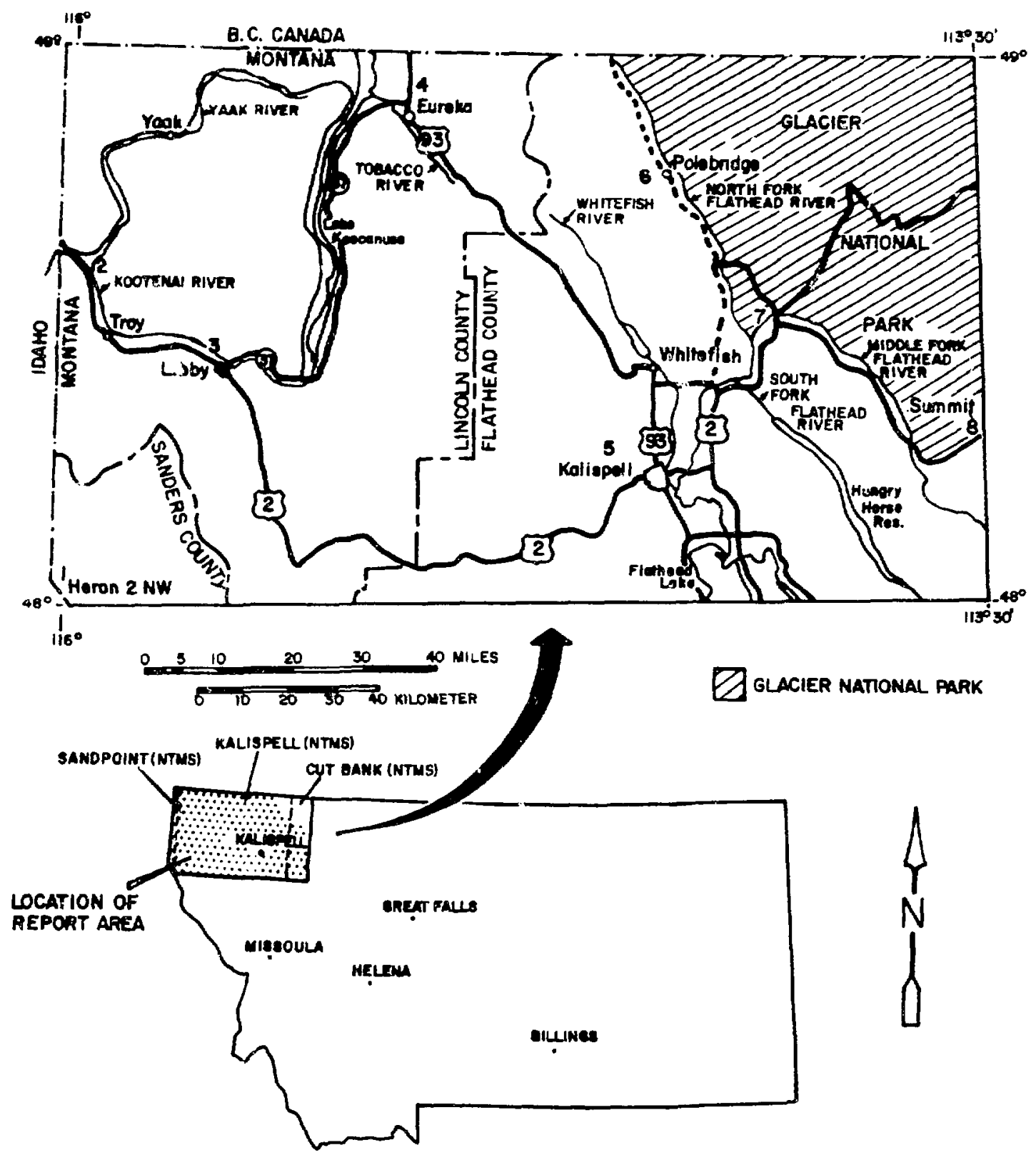

Fig. 1. Location of northwest Montana reconnaissance survey area. 
procedures were as specified by the LASL and are briefly described in Appendix A. All samples and field measurements were taken using equipment and materials furnished by the LASL. Throughout the survey, every effort was made to standardize each operation so that the resulting data would be intercomparable to the greatest extent possible.

\section{Sample Analysis}

Upon delivery to the LASL, all samples were inventoried and then distributed to two LASL analytical laboratories for analysis. All of the water samples were initially analyzed by fluorometry, and those found to exceed 10 parts per billion ( $\mathrm{ppb}$ ) uranium (the upper limit of detection without recalibration of the fluorometer) were also analyzed by a delayedneutron counting (DNC) technique. A comparison of the uranium in waters analyzed by both fluorometry and DNC has shown that the two analytical methods as used at the LASL are comparable. ${ }^{1}$ All of the sediment samples were analyzed for uranium in the parts per million (ppm) range, using the DNC method. Both of the analytical procedures used are described in more detail in Appendix A and in LASL HSSR Quarterly Progress Reports. ${ }^{2-8}$ In addition, a report describing the fluorometric method utilized at the LASL is available from the ERDA GJO and other ERDA repositories. ${ }^{9}$ As with the field procedures, all of the analytical work was performed using standard techniques and stringent controls to assure maximum accuracy and precision of the uranium data. Histograms for the uranium concentrations measured in the water samples, both combined and separated as to source, and for the sediment samples, likewise combined and separated as to source, are presented in Appendix B.

\section{GEOGRAPHIC SETTING}

The report area includes nearly all of Lincoln County and the western three quarters of Flathead County, both in extreme northwestern Montana. The primary industries in this part of Montana are lumbering, ranching, agriculture and tourism. The combined population of Lincoln and Flathead counties is approximately 60 000. The largest towns are Kalispell, Whitefish, and Columbia Falls in Flathead County, and Libby and Troy in Lincoln County. Approximately $80 \%$ of the land in the survey area lies within the boundaries of the Kootenai and Flathead National Forests, and the remaining land is either privately held ( $15 \%)$ or state owned $(\sim 5 \%)$. 
The study area lies cotaliy within the Northern Rocky Mountain Province, ${ }^{10}$ which is characterized by parallel, north- and northwesttrending mountain ranges separated by long deep valleys (Fig. 2).

The Dountains stard 2200 to $2700 \mathrm{~m}$ in height, while the valleys are comonly 600 to 1200 above sea level. Most of $t$ a major topographic features in northwestern Montana are related to regional faulting, continental and alpine g.aciation, and stream erosion. The mountains are covered with dense forests of pine, tamarack, and fir, while the valleys, except where cleared for agriculture or other purposes, are covered with both evergreen and deciduous trees and shrubs.

\section{Climate}

The climate of northwestern Montana is generally classified as a modified maritime type being dominantly influenced by the Pacific Ocean. ${ }^{11}$ Although the cemperature and precipitation are normally controlled by Pacific weather, there are times during the winter months when extremely cold, continental

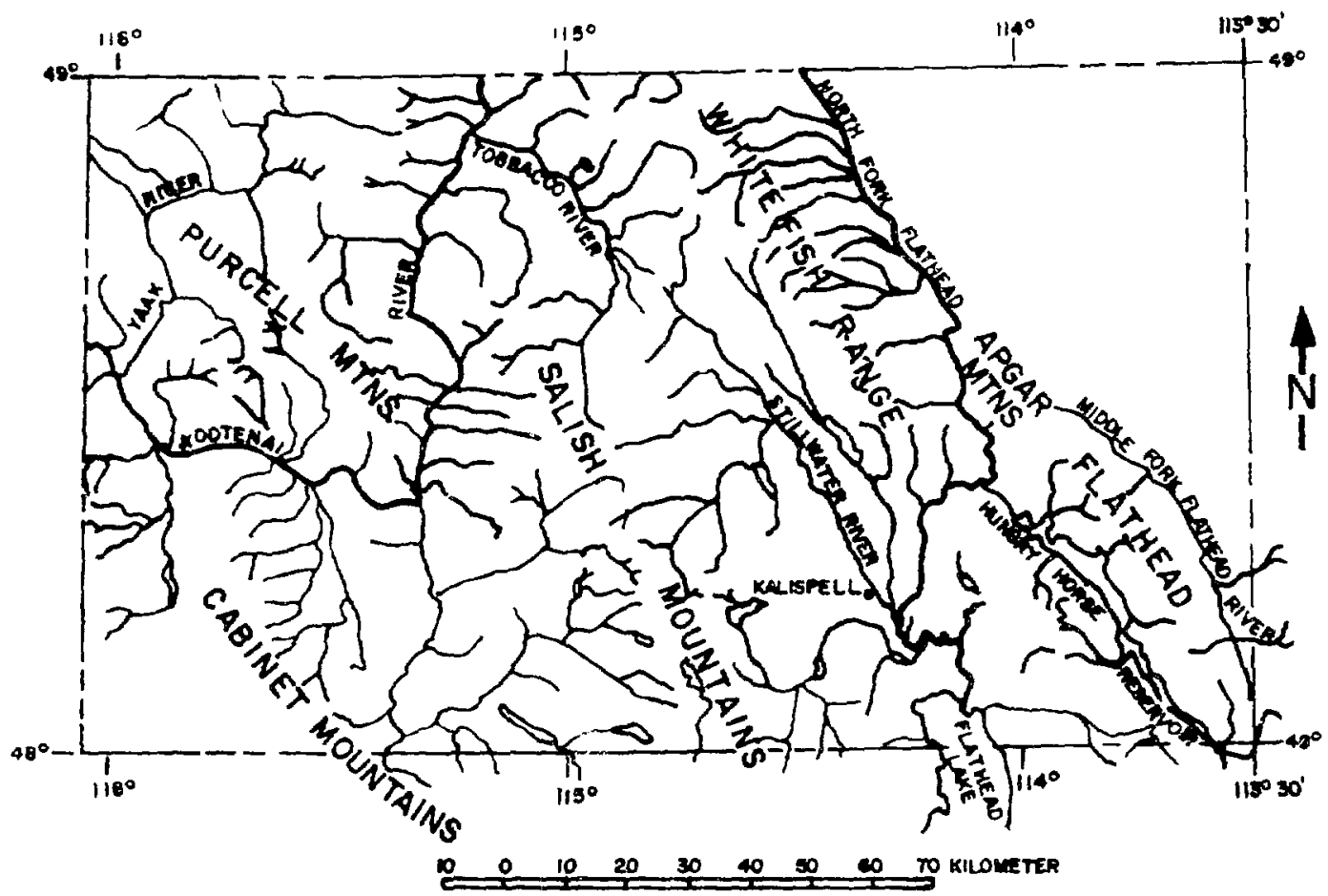

Fig. 2. Major rivers and mountain ranges in northwest Montana. 
weather will penetrate from the east, causing relatively brief intervals of extreme cold. The average annual temperature range is from about $7^{\circ} \mathrm{C}$ in the valleys to less than $2^{\circ} \mathrm{C}$ in the higher elevations. Summers are typically warm and sunny, while the winter months are cool and cloudy. Annual precipitation: ranges from $36.3 \mathrm{~cm}$ in the Kalispell valley to more than $100 \mathrm{~cm}$ in the mountainous areas, large:.y as a result of heavy winter snowfall. Table I summarizes the average annual temperature and precipitation for selected weather stations throughout the study area for the years 1970 through 1975. Table II sumarizes the temperature and precipitation at these stations during the months in 1976 that the field sampling was performed. For easy reference, the number to the left of each station name in Table II corresponds to the same number on Fig. 1 .

\section{HYDROLOGY}

Water draining the mountainous regions in Lincoln and Flathead counties flows into the valleys via many short and relatively steep tributaries to the primary streams and rivers. The metasedimentary Belt rocks, the predominant bedrock lithology in the region, are typically dense and impervious. Consequently, groundwater availability in the mountains is generally limited to those areas where the bedrock is fractured, fissured, or faulted. In the larger intermontane valleys, considerable thicknesses of glacial material (till, moraine, and outwash) have been deposited, and in these areas groundwater is plentiful. Recharge takes place along the flanks of the mountains where the glacial deposits pinch out, and discharge is primarily into the streams, pivers, and lakes on the valley floor. In the more populated valleys, a considerable amount of groundwater is pumped from wells for domestic and agricultural use. 11

Streams and lakes are numerous throughout the area, being fed by heavy winter snow accumulations and moderate summer rains. Many of the numerous small lakes in the area were formed as impoundments behind glacial moraines deposited as the alpine and continental ice sheets retreated. The major intermontane valleys contain well developed (mature) river drainages fed by streams draining the mountain slopes to the west and east. Two large reservoirs, the Hungry Horse, in Flathead County, and Koocanusa, in Lincoln County, are contained by dams. Hungry Horse Dam is on the South Fork of the Flathead River, northeast of Kalispell, while Lake Koocanusa is formed behind 


\section{TABLE I}

AVERAGE ANNUAL TEMPERATURE AND PRECIPITATION AT SELECTED WEATHER STATIONS IN NORTHWEST MONTANA FOR THE YEARS $1970-1975^{2}$

Average Annual Temperature $\left({ }^{\circ} \mathrm{C}\right)$ Average Annual Precipitation (cm)

Station $\quad \underline{1970} 197119721973 \quad 1974 \quad 1975 \quad 1970 \quad 1971 \quad 1972 \quad 1973 \quad 1974 \quad 1975$

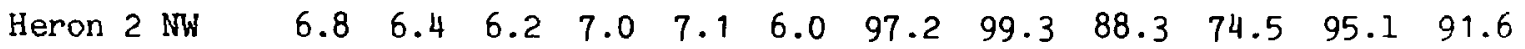

$\begin{array}{lllllllllllll}\text { Troy } 18 \mathrm{~N} & 5.9 & 6.1 & 5.8 & 6.1 & 6.0 & 5.3 & 80.5 & 99.4 & 92.1 & 89.8 & 116.8 & 103.7\end{array}$

$\begin{array}{lllllllllllll}\text { Libby Dam } & 6.1 & 6.7 & 6.2 & 6.6 & 7.4 & 6.1 & 41.7 & 48.0 & 42.5 & 28.9 & 38.4 & 42.7\end{array}$

$\begin{array}{lllllllllllll}\text { Eureka R.S. } & 6.6 & 7.0 & 6.2 & 7.3 & 8.3 & 6.6 & 32.8 & 34.0 & 34.9 & 23.8 & 26.6 & 33.6\end{array}$

Kalispel1 A.P. $\begin{array}{llllllllllll}5.6 & 5.7 & 5.5 & 6.7 & 6.8 & 5.3 & 44.1 & 41.8 & 37.2 & 30.1 & 35.5 & 43.1\end{array}$

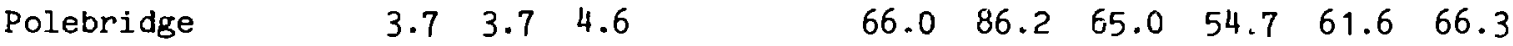

$\begin{array}{lllllllllllll}\text { West Glacier } & 5.3 & 5.2 & 4.9 & 6.0 & 6.2 & 4.8 & 89.9 & 91.8 & 80.4 & 64.2 & 75.0 & 82.7\end{array}$

$\begin{array}{llllllllllllll}\text { Summit } & 1.9 & 1.4 & 2.6 & 2.1 & 0.7 & 114.7 & 108.4 & 110.9 & 75.6 & 7.08 .0 & 103.3\end{array}$

a See Ref. 12 .

TABI,E II

SUMMARY OF AVERAGE MONTHLY TEMPERATURE AND PRECIPITATION AT

SELECTED WEATHER STATIONS IN NORTHWEST MONTANA FOR

THE MONTHS OF MAY AND JUNE $1976^{\mathrm{a}}$

No.

on

Fig.

1 Station

1. Heron $2 \mathrm{NW}$

2. Troy $18 \mathrm{~N}$

3. Libby Dam

4. Eureka R.S.

5. Kalispell A.P.

6. Polebridge

7. West Glacier

8. Summit

$\overline{\text { See Ref. } 12}$.
MAY 1976

$\frac{\text { Temperature }\left({ }^{\circ} \mathrm{C}\right)}{\text { Ave. Ave. Potal }}$ Ave. High Low (cm)

$\begin{array}{llll}11.6 & 20.7 & 2.4 & 4.75\end{array}$

$\begin{array}{llll}11.3 & 20.6 & 2.1 & 4.57\end{array}$

11.8

21.6

$2.1 \quad 2.72$

10.2

22.7

$3.6 \quad 3.20$

$3.9 \quad 4.55$

$0.1 \quad 5.03$

$\begin{array}{llll}11.1 & 20.0 & 2.2 & 7.19\end{array}$

7.8

15.3

$0.2 \quad 5.21$
JUNE 1976

Temperature $\left({ }^{\circ} \mathrm{C}\right) \quad$ Total Ave. Ave. Precip. Ave. High Low (cm) $\begin{array}{llll}12.6 & 20.2 \quad 4.9 & 5.84\end{array}$

$\begin{array}{llll}12.3 & 20.1 & 4.6 & 5.49\end{array}$

$\begin{array}{llll}12.9 & 20.8 & 5.1 & 2.26\end{array}$

$\begin{array}{llll}13.9 & 21.8 & 5.9 & 4.93\end{array}$

$\begin{array}{llll}13.3 & 20.2 & 6.8 & 4.29\end{array}$

$\begin{array}{llll}10.2 & 17.9 & 2.5 & 6.10\end{array}$

$\begin{array}{llll}12.4 & 19.2 & 5.7 & 8.36\end{array}$

$\begin{array}{llll}8.9 & 15.1 & 2.8 & 6.10\end{array}$ 
Libby Dam on the Kootenai River, east of Libby. Flathead Lake, south of Kalispell, was originally impounded behind glacial material but is now controlled by a dam at its southern end. Detailed information about the water resources of Lincoln and Flathead Counties is available in a water resources survey report issued by the Montana State Engineer's Office. 11

The waters of nurthwester Montana are generally classified as a calcium bicarbonate type having a dissolved-solids range of between 50 and 500 ppm. Various water chemistry measurements taken at selected river and stream sites in this part of Montana are available in the US Geological Survey (USGS) Water Supply Papers published by the US Government Printing Office, Washington, DC, as annial reports, entitled, Quality of Surface Waters of the United States (year), Parts 12-16. Included in these reports are data on water temperature, flow rate, sediment load, hardness, dissolved solids, $\mathrm{pH}$, specific conductance, silica, iron, calcium, magnesium, sodium, potassium, bicarbonate, carbonate, sulfate, chloride, fluoride, nitrate, and boron. Although the measurement sites are almost all located on the primary streams and rivers in northwest Montana (which were usually not sampled for the HSSR), the surface water chemistry is quite uniform throughout the area, and therefore the data are generally representative of the smaller streams as well.

\section{GEOLOGY}

The following brief descriptions of the geology, structure, mineral districts, and mines in Lincoln and Flathead counties have been compiled largely from a report by W. M. Johns, published in $1970 .^{14}$ other references are cited where appropriate.

Nearly all of northwestern Montana is underlain by thick sequences of Precambrian metasedimentary rocks broadly classed as the Belt supergroup. The Belt strata have been divided into four major subdivisions, which, in ascending order, are the pre-Ravalli, Ravalli, Piegan, and Missoula groups. The lower (pre-Ravalli and Ravalli) and the upper (Missoula) groups are composed primarily of clastic material (originally clay, silt, and sand) altered to argillite, siltite, and quartzite. The middle (Piegan) group is predominantly carbonate (limestone and dolomite) with the clastic content increasing near the upper and lower contacts. The carbonate sequence is thought to have been deposited in shallow to moderate water depths during repeated encroachments of a westerly sea. The total thickness of the Belt 
supergroup in northwestern Montana has not yet been determined. However, the maximum measured thickness of combined sections is $2 n 400 \mathrm{~m}$, measured at two exposures near Alberton, Montana, just south of the survey area. 15 Incomplete sections measurej elsewhere in northwest Montana range from 12200 $\mathrm{m}$ (in western Lincoln County) to $6100 \mathrm{~m}$ (in the Mission Mountains southeast of Flathead Lake). ${ }^{16}$ The names and general stratigraphic relationships of important subunits within the Belt supergroup in northwestern Montana are shown in Fig. 3, along with a generalized post-Precambrian stratigraphic section for units in the northern Whitefish Mountain Range, northwestern Flathead County.

Paleozoic rocks occur at only a few places within the survey area. Cambrian, Deyonian, Mississippian, and Pennsylvanian-Pemian rocks have been mapped at a few localities in western Lincoln County and northern Flathead County. The Cambrian, Devonian, and Mississippian rocks are predominantly carbonates (limestones and dolomites) and interbedded shales. The basal Cambrian unit is a light gray to brown, medium-grained, quartzitic sandstone. The Pennsylvanian-Permian rocks are well-sorted, fine-grained quartzite, exposed in the northern part of the Whitefish Range near the Canadian border.

Mesozoic rocks are exposed both in the Whitefish Range, and in the Swan Range, south of Hungry Horse Reservoir. Included in the Mesozoic strata are limestones, dolomites, and shales of Jurassic and Cretaceous age. Triassic siltstones and shales, which underlie Jurassic limestone and shale elsewhere in Montana, have not been identified within the survey area.

Cenozoic rocks are exposed in the Northfork and Sout'ufork valleys of the Flathead River, northeast of Kalispell. These limited outcrops include arenaceous shales, vari-colored sandstones, and minor conglomeratic facies. Lignite beds having up to $10 \mathrm{~m}$ of aggregate thickness occur in the Tertiary strata (Kishenehn $\mathrm{fm}$ ) in the Northfork valley. Lignite beds have also been identified in Tertiary strata in the Southfork and Middlefork valleys of the Flathead River.

Quaternary deposits are distributed in all of the intermontane valleys of northwestern Montana. Glacial deposits consisting of till, moraine and outwash material, and lacustrine clay and silt are especially prevalent in the northern valleys and canyons. Hecent alluvium is commonly distributed along the drainages of present day rivers and streams. 


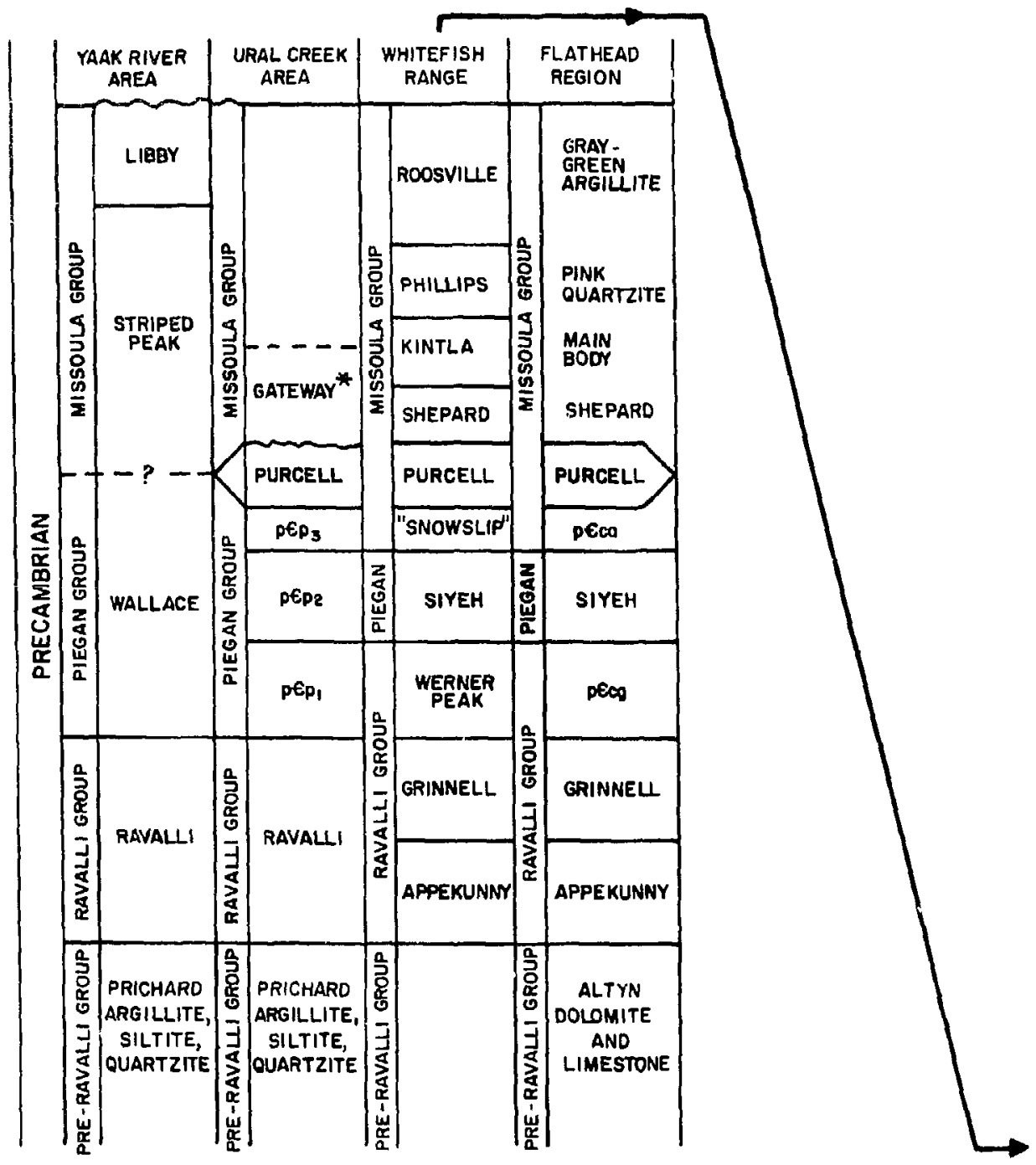

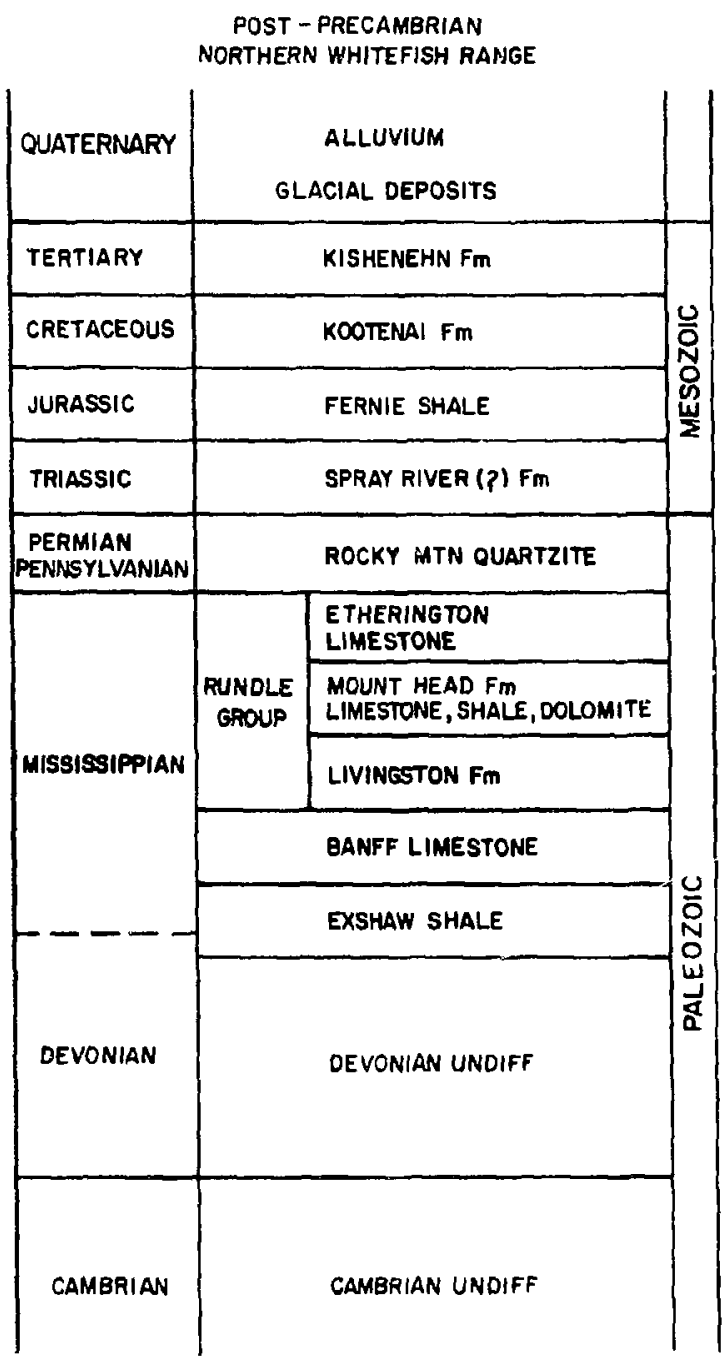

GATEWAY* - DESCRIBED GY SHELOON (1961) AS EQUIVALENT SHEPARD FORMATION

Fig. 3. Simplified correlation of Precambrian sedimentary units in northwestern Montana with post-Precambrian stratlgraphy in northwest Flathead County. 
Igneous Rocks in the Area

During late Precambrian and Mesozoic-Cenozoic times, the Belt strata were invaded by a variety of extrusive and intrusive rock types. The Purcell lava (andesite and basalt) was extruded during late Precambrian time as two broad sheets across a large area west of what is now Glacier National Park and extending north into Canada. The Purcell flows generally thicken to the north and west, being as much as $225 \mathrm{~m}$ thick in a section measured near Eureka, Montana. East a d west of the Eureka area the Purcell lava ranges from 100 to $140 \mathrm{~m}$ in thickness. Other basic rocks occur as intrusive dikes and sills at various localities in Lincoln and Flathead Counties. In Lincoln County they are compositionally described as equivalent to metagabbro, hornblend gabbro, amphibolite, and metadiorte. In Flathead County, near Giacier Park, they are described as being metagabbros, but farther south, equivalent intrusives are classified as quartz diorites. The age of these intrusives has not been definitely determined; however, early investigators assigned the more basic units (diorites) to the Precambrian, probably being equivalent to the Purcell lava. The diabasic dikes and sills have been tentatively assigned to the Cretaceous due to their proximity and structural relationship to granitic stocks and dikes of that age described below.

During Late Cretaceous (Laramide) time, diastrophic stress and its subsequent release created the Northern Rocky Mountains. During this period of mountain building, the Precambrian metasediments were intruded by many granitic dikes and stocks. The exposed areas of wost of these intrusive bodies are quite limited within the survey area, but farther to the south and southeast, large plutons of Laramide age (Idaho and Boulder Batholiths) are exposed. The intrusive bodies are notable, because nearly all of the significant mining districts in Lincoln and Flathead counties are associated with them. Descri $i_{i}$ tions of the intrusive bodies are provided in reports by Gibson ${ }^{17,18}$ and Gibson, et al. 19-21 Additionally, the report by Johns ${ }^{14}$ synthesizes most of the available information on these bodies in considerable detail. Finally, the USGS has conducted airborne geophysical surveys over parts of Lincoln and Flathead Counties, and the resulting aeromagnetic maps $\left(\mathrm{GP}-830^{22},-682^{23},-683^{24}\right.$, and $\left.-684^{25}\right)$ are useful for locating the larger intrusive areas and fault zones, and also for identifying lithologies having relatively high percentages of magnetite.

Volcanic intrusive and extrusive rocks of Tertiary age occur just south of the survey area and approximately $20 \mathrm{~km}$ west of Flathead Lake. They are 
the host rocks for important silver and lead deposits in the Hog Heaven mining district. The volcanics have been classified as porphyritic andesites, latites, andesitic tuffs, and basalts and are exposed over a $250-\mathrm{km}^{2}$ area. ${ }^{26}$ A few of the streams draining the Hog Heaven district flow northward and enter the study area along its south-central borcier.

\section{Structural Setting}

Structurally, northwestern Montana is comprised of an ancient anticlinorium (the Purcell anticlinorium, initially formed in Late Precambrian) 27 of north-northwest-trending folds and faults, which during the Laramide orogeny underwent further folding, extensive block faulting, and thrusting. 22 During Tertiary time, additional, but less extensive, movement took place along some of the major fault systems in the area. The primary tectonic features of northwestern Montana are shown in Fig. 4.

Precambrian strike-slip fault movement has been documented along the western part of the Lewis and Clark line, southwest of the survey area, by Hobbs, et al. ${ }^{28}$. Harrison has indicated evidence for Precambrian movement along the Hope fault, which cuts across the extreme southwestern corner of the survey area. ${ }^{15}$ subsequent, block faulting during late Mesozoic time resulted in the formation of the Purcell trench, the Libby trough, and the Rocky Mountain trench, all of which are graben structures. ${ }^{15}$ During this same period, the Montana "disturbed belt," which trends to the northwest along the eastern boundary of the survey area, and the Kootenai "mobile telt," west of the surve; area in Idaho and Washington, were developing. In addition to the gross structural features mentioned, there are numerous other faults, fissures, and joints which are related, either in time or space, to these larger structures. Many of them are described in considerable detail in the 1970 report by Johns. ${ }^{14}$ It is important to recognize that most of the intrusive rock occurrences, which are the hosts for nearly all of the economically important mineral deposits in northwest Montana, are associatec with structural features.

Mineral Occurrences in the Area

Since the late 1800 's, sporadic mining in eight districts within the survey area has produced several million dollars worth of silver, lead, gold, 


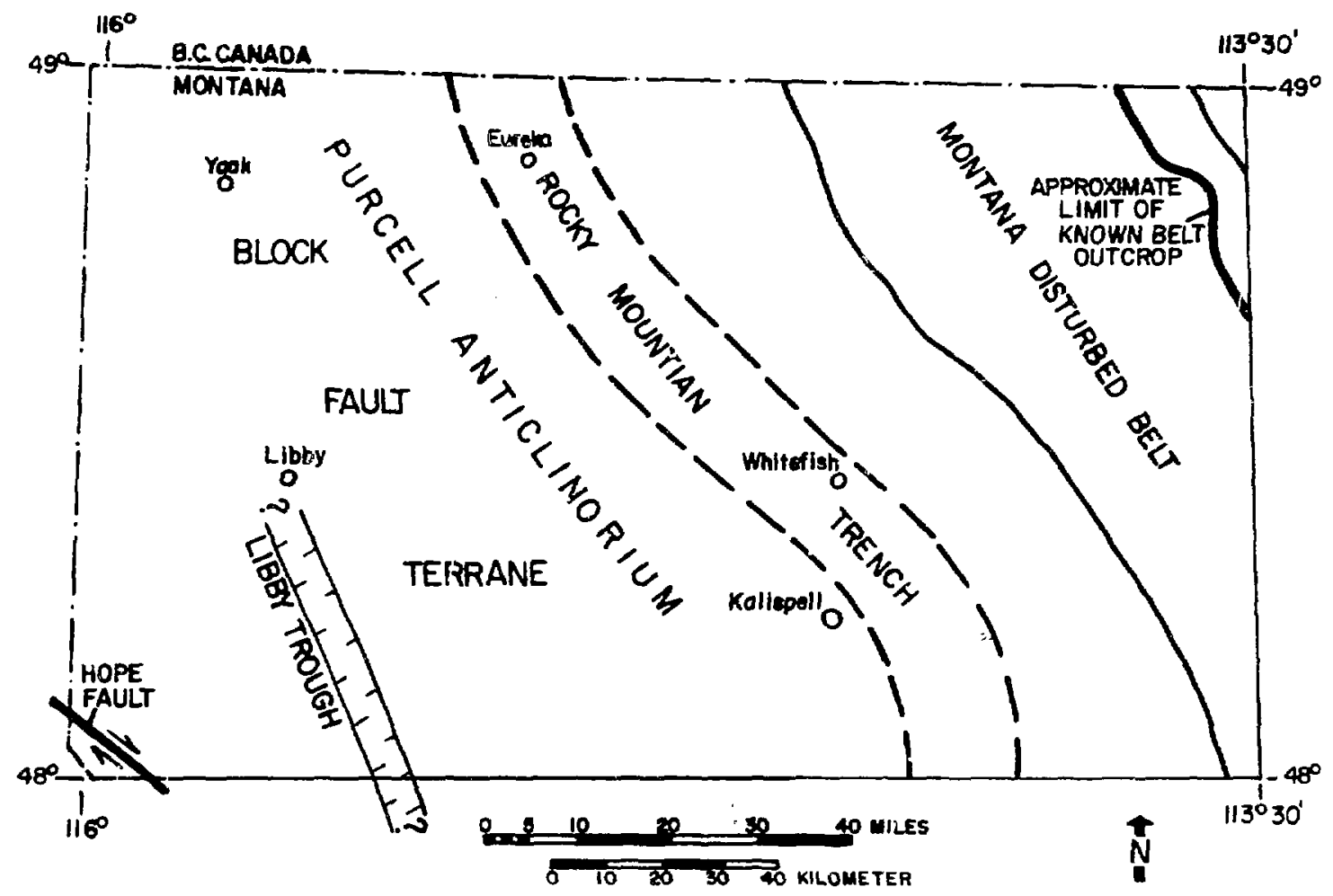

Fig. 4. Tectonic map--northwest Montana.

zinc, and copper, as well as a small amount of tungsten. Most of this ore was produced or originated (in the case of placer deposits) from mesothermal and epithermal veins filling fissures and fractures associated with large faults and folds. Placer gold his been recovered from several stream beds in the western part of the survey area (Lincoln County), and a few streams in the eastern part (Flathead County). The value of the gold and minor quantities of silver produced from placer deposits has been relatively small when compared to the direct production from veins. Non-metallic minerals, in order of decreasing economic importance within the area, include vermiculite, barite, coal, tremolite (asbestos), talc, and limestone. Of these, only the first three have been mined to any significant extent, and only vermiculite is actively produced at present. The locations of mineral producins districts in the study area are given in Fig. 5, and summary descriptions of the major ones are provided in Table III. 


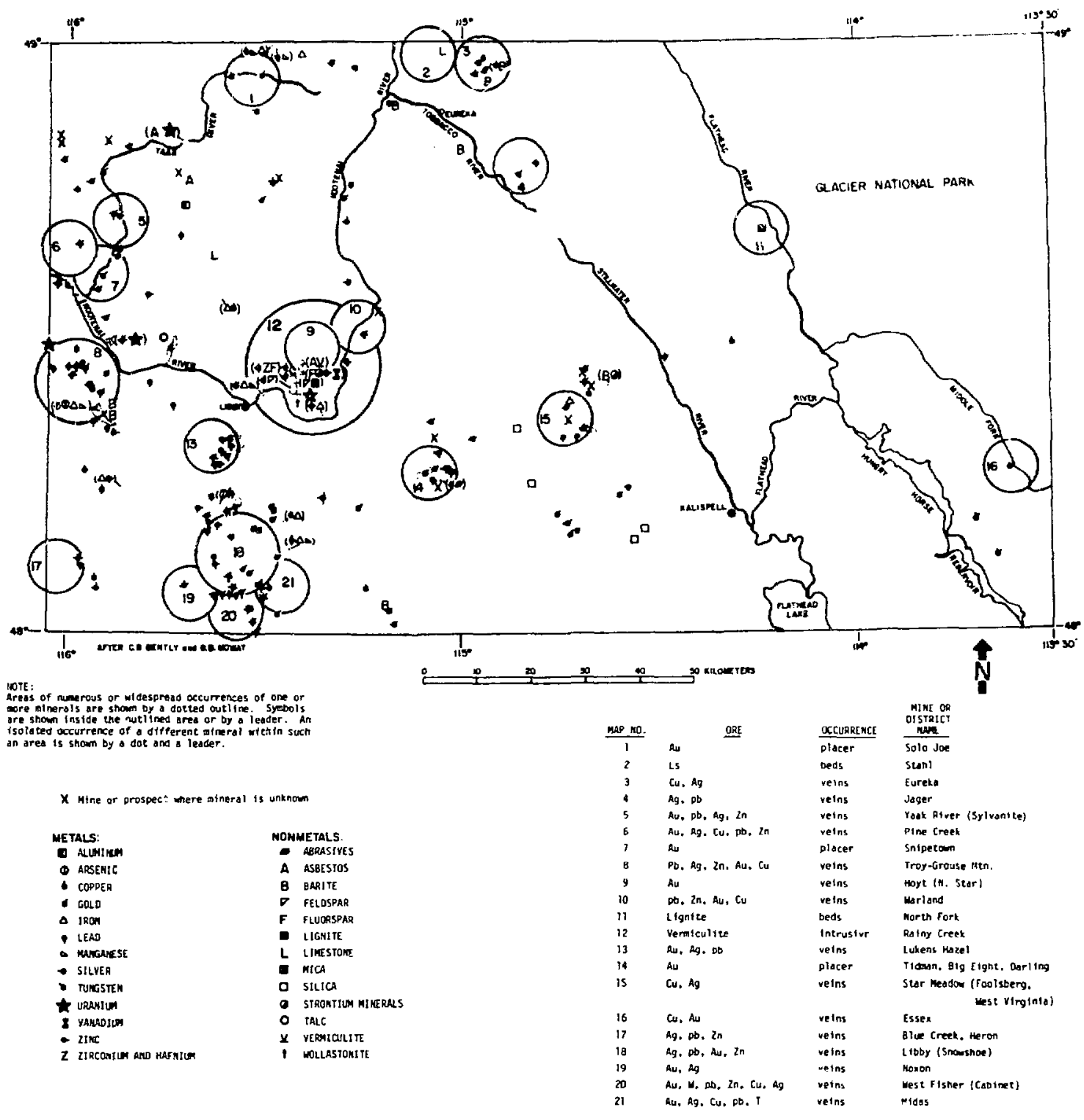

Fig. 5. Mining districts and mineral deposits--northwest Montana. 


\section{SUMMARY DESCAIPTIONS OF MAJOR MINING DISTRICTS \\ IN LINCOLN AND FLATHEAD COUNTIES, NORTHWEST MONTANA ${ }^{a}$ \\ (With reference to locations as shown on Fig. 5)}

\section{Lincoln County}

Libby District (Nos. 18 and 19 on Fig. 5)--Located on the western flanks of the Cabinet Mountains approximately $35 \mathrm{~km}$ south of Libby. Mines in the district have produced lead, silver, and gold (largely from the Snowshoe Mine). Ore occurs in replacement veins in shear sones and faults in Precambrian argillite.

Troy District (No. 8 on Fig. 5) --Located in the northwest Cabinet Mountains approximately $10 \mathrm{~km}$ southwest of Troy. Mines in the district have produced lead, zinc, copper, and some gold and silver (most prior to 1930). Barite veins also occur in the area. Ore is from replacement veins and fillings in metadiorite dikes cutting Precambrian argillite.

West Fisher District (Nos. 20 and 21 on Fig. 5)--Located near the headwaters of the West Fisher River approximately $40 \mathrm{~km}$ south of Libby. Gold, silver, and small amounts of tungsten and sulfide minerals have been produced from quariz veins cutting Precambrian argillite and quartzite of the Prichard Formation.

Sylvanite District (No. 5 on Fig. 5) --Located in the Purcell Mountains, on the west side of the Yaak River, approximately $30 \mathrm{~km}$ north of Troy. Gold, lead, silver, and zinc have been produced from vein filled fissures.

Warland District (No. 10 on Fig. 5) --Located a few $\mathrm{km}$ northeast of Warland in the Salish Mountains.

a See Ref. 29 .
Gold, copper, lead, and zinc have reportedly been mined from quartz veins cutting a syenite stock.

Rainy Creek District (No. 12 on Fig. 5)--Located approximately 15 km northeast of Libby in the Purcell Mountains (Vermiculite Mountain). Large open pit vermiculite mine produces up to 500 tons of concentrate per day from the Rainy Creek Pluton. Other minerals known to occur in the biotite-magnetite-pyroxenite and syenite pluton include tremolite (amphibole asbestos), chalcopyrite, bornite, sphalerite, fluorite, pyrite aegirine, rutile, and calcite. Feldspar, biotite, magnetite, apatite, and pyroxene have been described as being possible future resources.

\section{Flathead County}

Star Meadows District (No. 15 on Fig. 5)--Located approximately 40 $\mathrm{km}$ northwest of Kalispell and west of Tally Lake. Silver, gold, and copper are associated with quartz and siderite veins in faults cutting Precambrian argillite.

Hog Heaven District (not shown on Fig. 5)--Located approximately $5 \mathrm{~km}$ south of the survey area and $25 \mathrm{~km}$ west of Flathead Lake, in the Salish Mountains. Silver and lead are mined from dikes and plugs intruding volcanic rocks, from replacement deposits in the volcanics, and from fumarole holes penetrating Precambrian metasediments adjacent to the igneous bodies. 


\section{Uranium Occurrences in the Area}

Production of uranium or associated radioactive minerals is not known in northwestern Moniana. There are, however, a few locations within or adjacent to the survey area where notable, but minor, occurrences of radioactive minerals have been identified. These local areas having known or suspected uranium mineralization are described below.

In Lincoln County, approximately $10 \mathrm{~km}$ west of the town of Troy, Montana; the Oro Mine is located near the headwaters of Ruby Creek. The mine is developed in a quartz vein cutting a metadiorite dike which strikes $N 40^{\circ} \mathrm{W}$. The ore consists of galena, anglesite, chalcopyrite, and pyrite in quartz. Vuggy material within the vein contains abundant iron oxides ( $3.3 \%$ iron) and assays 5.1\% lead. It also has minor amounts of silver and traces of gold, copper, and zins. At least one assay showed $0.5 \%$ nickel in disseminated ore from this locality. 14 In a reconnaissance of the Oro Mine, it is reported that the detectable radiation levels along the quartz veins are locally four to ten times nigher than the regional background. 30 The specific radioactive minerals are not identified at this location.

A second location having radioactive mineralization in Lincoln County is situated approximately $7 \mathrm{~km}$ east of Libby $3.5 \mathrm{~km}$ southwest of Vermiculite Mountain), in the Rainy Creek district. Twelve claims along two parallel quartz-bearing shear zones have been explored. The westerly shear zone (Raven group) contains galena, cerussite, chrysocolla, malachite, and tremolite. The easterly zone (Lucky Mac group) is located approximately $0.4 \mathrm{~km}$ to the east, and contains (in addition to quartz) galena, fluorite, and sparse radioactive autunite (calcium uranium phosphate). The radioactivity was detected in bulldozer cuts and pits and has been traced along the shear zone for some 500 m. Although selected vein samples have assayed as high as $17.0 \%$ lead and $7.5 \%$ zirconium oxide, and show a trace of silver, no production has been reported from the Lucky Mac group. 14

Approximately $9 \mathrm{~km}$ east of Libby and on the southern contact of the Vermiculite Mountain pluton, scintillometer readings made in the mid-1950's indicated local radioactivity. Trenching exposed a diorite dike locally stained with iron and copper oxides and containing pyrite crystals up to 0.6 $\mathrm{cm}$ in size. Samples from two locations along the $0.8-\mathrm{km}$ exposure of the dike showed traces of copper, silver, and zinc, and up to $0.2 \%\left(\mathrm{U}_{3} \mathrm{O}_{8}\right)$. It has been speculated that the dike and surrounding country rock (Wallace fm) 
contain sparse amounts of autunite. The Kennedy group, as the above claims are known (due to their proximity to Kennedy Gulch), have not been developed beyond tine few prospect trenches mentioned. ${ }^{14}$

A fourth radioactive mineral area where autunite has been reported is located approximately $0.8 \mathrm{~km}$ northwest of $\mathrm{Yaak}$, in the northwestern corner of the study area. This occurrence, staked as the Esther May claims in 1946, is associated with a $7.6-\mathrm{cm}$ thick syenite vein exposed in a small exploratory pit. The clains have not been developed except for the shallow pit and several expleratory drill holes. The Esther May claims were originally staked on the basis of the tremolite (asbestos) in small veins in the area. 14

A fifth area described as having minor uranium mineralization is shown on Fig. 5 as being $5 \mathrm{~km}$ north-northeast of Troy. No other information about the mineralization at this location was found, and no other occurrences of radioactive minerals in northwestern Montana were noted in the literature. It seems likely, however, that similar but yet unidentified occurrences might exist here, particularly in association with the acidic intrusive rocks. The following sections present a brief evaluation of the survey results, which it is hoped will provide some useful direction for those making a more thorough study of these data.

\section{v. GEOCHEMICAL NATURE OF URANIUM}

There are numerous written reports on hydrogeochemical and stream sediment reconnaissance methods of prospecting for uranium which show that properly designed surveys can be a valuable tool, both for regional resource assessment and as a guide for exploration. 31 The reasons for this, while complex, are basically founded in the fact that uranium is an oxyphile element readily dissolved in and transported by circulating waters under a wide range of natural conditions. 32 It is also easily adsorbed, over a wide $\mathrm{pH}$ range, on certain clays, organics, and other carbonaceous matter with which the waters come into contact. 33 Because all natural surface and ground waters do carry uranium in solution in greater or lesser amounts, depending on numerous chemical and physical conditions, they provide an excellent sample medium with which to delineate favorable and unfavorable areas for uranium enrichment. 34,35 Additionally, fine grained, organic rich, water transported sediment provides a complementary sample medium in regions where surface waters are plentiful. 
Sowe of the more important chemical factors which act to control the solubility of uranium in water are $\mathrm{pH}$, specific conductance, Eh, and alkalinity. Of these, $\mathrm{pH}$ and specific conductance, which can be quickly and easily determined in the field, were measured in this survey and are included in the data listings of Appendixes $C$ and $D$. Some of the physical factors acting to control the uranium contents in both water and sediment include the geology, geochemistry, and hydrology of an area, the availability of soluble uranium, the residence time of the waters, the amount of colloids, clays, and organic matter in the water and sediment, the water temperature, the seasonal climate, the weather, and the relationship between surface and ground waters. $36-38$

Summarized below are some of the important relationships of the chemical and physical parameters provided in the data listings of Appendixes $C$ and $D$ to uranium contents as measured in water and sediment.

$\mathrm{pH}$ - Uranium is soluble over a wide range of $\mathrm{pH}, 32$ and it is only when extreme high or low values are encountered that it becomes important to interpretation. ${ }^{39}$ As $\mathrm{pH}$ decreases, uranium content increases. 36,40

Specific conductance - An increase in total dissolved solids (approximated by specific conductance) will usually be accompanied by an increase in uranium in natural vaters. $38,41-44$

Equivalent uraniem - A measurement of surface radioactivity (uranium and thorium daughter prodicts) at each location is provided for use alone, or with NURE airborne radiometric results when they become available. An abnormally high value is indicatjue of local radioactive mineralization. 45

Temperature - The temperature of the water may influence the measured concentration of uranium to some extent since it controls the rate of certain chemical reactions and biological activity. 36,39

Geology - Uranium content is generally higher in waters draining certain lithologies (such as acid igneous types). ${ }^{46,47}$ oxidizing groundwaters of ten circulate in highly fractured, fissured, and faulted terrains and can act to introduce dissolved uranium into the surface waters in favorable areas. $33,34,36,38,48-50$

Organics - The organic content can be crudely approximated from the water description, bottom sediment description, density and type of local vegetation, and water temperature as recorded at the time of sampling. High organic content tends to rapidly adsorb uranium from water and correspondingly 
increase uranium in sediment. 38,51 In heavily vegetated terraines, short dispersion trains in stream water, and to a lesser extent in sedirent, can therefore result. 33,42

Relief - Surface waters draining mountainous regions tend to have relatively short dispersion trains of uranium. 52,53

Weather - Seasonal climatic and weather conditions tend to change the uranium concentrations in surface waters and, to some extent, in sediment. $33,36,37,54$ During periods of rapid snowmelt and high runoff, the normal uranium concentrations may be diminished by a factor of 1 to 3 times, due to dilution. Following periods of drought, the uranium content in rainwater runoff has been found to sharply increase for a brief period. 40,54,55 In standing waters, where evaporation is prevalent (lakes and ponds) the uranium content tends to increase. 37,56 Hydrogeochemical surveys should be completed over a short period of time to minimize the influence of seasonal change 49,57

Contaminants - The identification of potential sources of contamination, such as metal mines, dump residues, and acid mine waters, can be important to making a correct interpretation of the uranium data. $40,52,58$ The use of uranium-rich phosphate fertilizers might increase the uranium concentration of waters in certain agricultural areas. 59

\section{STATISTICAL AND EMPIRICAL EVALUATION OF THE WATER DATA}

The following section presents basic statistical data for the urantut analyses of water samples from northwestern Montana. All of the sample locations mentioned are designated by number (with the first two digits dropped) on the overlay of Plate II, and the uranium concentrations in water are graphically portrayed on the overlay of Plate III. A summary of the uranium data for all of the water samples combined, as well as for the various individual source types, is provided in Table IV.

of the total of 1684 water samples reported from within the survey area, 821 were found to have less than detectable concentrations of uranium $<0.2$ ppb). All waters analyzed by fluorometry were done in duplicate, with the values shown being the average of the two determinations. Occasionally, one split of a sample would result in a concentration at or slightly above the detectable limit, while the other was below the limit. In such cases, the lower concentration of uranium $(<0.2 \mathrm{ppb})$ was arbitrarily assigned a value of 
SUMARY OF URANIUM DATA FOR FILTERED AND ACIDIFIED WATER SAMPLES

COLLECTED IN NORTHWEST MONTANA

$\begin{array}{lcccc}\begin{array}{l}\text { Sample } \\ \text { Source }\end{array} & \begin{array}{c}\text { No. of } \\ \text { Samples }\end{array} & \begin{array}{c}\text { Range } \\ \text { (ppb) }\end{array} & \begin{array}{c}\text { Mean } \\ \text { (ppb) }\end{array} & \begin{array}{c}\text { Standard } \\ \text { Dev.(ppb) }\end{array} \\ \begin{array}{lccl}\text { All waters } \\ \text { Stream waters }\end{array} & 1684 & 0.10-173.60 & 0.66 & 4.53 \\ \text { Natural pond waters } & 1582 & 0.10-22.00 & 0.47 & 1.12 \\ \text { Spring waters } & 44 & 0.10-173.60 & 5.16 & 26.24 \\ \text { Artificial pond waters } & 41 & 0.10-31.40 & 2.95 & 6.62 \\ \text { Well waters } & 14 & 0.10-5.45 & 1.18 & 1.79\end{array}$

$0.1 \mathrm{ppb}$, and then it and the higher value were averaged. Values for water in the data listings of Appendix $C$ which are between 0.1 and $0.2 \mathrm{ppb}$ were arrived at in this nanner. Because of the high number of very low concentrations (<0.2 ppb), it is alnost certain that the statistical distribution for the uranium in waters is skewed somewhat toward the high side (i.e., had the actual low concentrations been aeasured, the mean value (M) for the whole population might be slightly lower than it is when these low concentrations are arbitrarily assigned a value of $0.1 \mathrm{ppb}$ ).

There are probably severai reasons for so many of the water concentrations being below 0.2 ppb uranium. The most important ones are believed to be seasonal dilution, rapid transit times of the stream waters, and quite possibly a general lack of leachable uranium in this area of Montana. It has beer shown that there is a discernable decrease in the amount of dissolved uranilim in surface waters at higher latitudes, ${ }^{38}$ and this may also be reflected in the numerous low concentrations in northwestern Montana waters.

When evaluating uranium results from mixed water sample populations (different source types), it is important to recognize that they are usually not directly comparable. Several reasons for this are alluded to in the previous section on the geochemical nature of uranium. The results of the 
analyses of water samples from northwestern Montana indicate that they are somewhat more statistically comparable than would normally be expected. Only the natural pond waters and spring waters, which have populations of 44 and 41 samples respectively, have notably higher mean values and larger standard deviations $(\sigma)$ from the mean than the other sample types. In both cases, these statistical values (Table IV) are skewed to the high side due to the existence within the populations of a few very high urantum concentrations.

In the case of the natural pond waters, if the two highest uranium concentrations ( 173.60 and $23.50 \mathrm{ppb}$ ) are removed, the mean for the remaining 39 samples is $0.71 \mathrm{ppb}$, which is very close to $0.66 \mathrm{ppb}$, the mean for all of the water samples combined. The range of these 39 samples is 0.10 to 7.25 ppb, which is well within two standard deviations from the mean for all of the water samples combined.

For the spring waters, it is necessary to remove the six highest values $(31.40,25.20,19.10,5.93,5.72$ and $4.02 \mathrm{ppb})$ to bring the mean of the remaining 35 down to $0.83 \mathrm{ppb}$, close to the mean for all samples. If only the three highest values are dropped from the spring waters, the mean fur the remaining 38 samples is $1.20 \mathrm{ppb}$ uranium. This probably indicates that the spring water population does in fact have a slightly higher average uranium concentration than the other sample types. This is not unexpected, inasmuch as groundwaters generally have been found to contain somewhat higher concentrations of dissolved uranium. ${ }^{1}$ For the purpose of a gross interpretation of these data, the difference between the statistical results for the total water population and the small spring water population is not believed to be so great as to require separate evaluations. The histograms provided in Appendix B, however, do separate the uranium data on the basis of sample type (with the exception of three well water samples which were not plotted) and the results portrayed there can be used for making separate and more refined evaluations, if desired. Histograms for both the raw data and log-data distributions are included in Appendix B, but no attempt has been made here to establish which distribution (if either) better represents the data for purposes of interpretation. It should be noted that the concentration intervals used for the histograms in Appendix B were selected arbitrarily on the basis of the range of uranium concentrations and not on the statistical distribution from the mean value, as used on plates III ari IV in the rear pocket. 
In a uranium HSSR study of samples from the Estancia Valley, New Mexico, by 0lsen, published earlier in $1977,{ }^{60}$ the uranium cencentration in waters (grouped by source type) appeared to have a Poisson-like distribution (where $M$ $\approx$ yariance). The differences between the mean concentration values and the variance from the mean for all samples combined, and for each grouping by source type, indicates that the northwestern Montana waters probably do not possess a Poisson-type uranium distribution as was indicated for the samples in the New Mexico study. Here again, however, the large number of very low uranium concentrations ( $<0.2 \mathrm{ppb}$ ) may be effectively masking or altering the true statistical distribution, and thus any conclusions derived solely from a statistical treatment of these data are only tentative.

The question of just what constitutes an anomalously high (or low) concentration of uranium in natural waters is difficult to determine, particularly in regional surveys where background concentrations can change from area to area within the region. A simple and reasonably effective guide which is commonly used to select anomaly cutoffs is based on the statistical distribution of the results. Some geochemists use $M+2 \sigma$ (or the high side of the $95 \%$ confidence limit) as the anomaly threshold in hydrogeochemical prospecting, shile others use $M+3 \sigma$ (the high side of the $99 \%$ confidence limit). 61 The uranium concentrations plotted graphically on Plate III are differentiated, to the extent possible, using full and half deviations from the mean for all of the samples combined. This was done so that investigators wishing to use either of the above statistical values (or an intermediate one) as anomaly thresholds could do so directly.

There are eight water samples having measured uranium concentrations greater than $14.25 \mathrm{ppb}$, which is the anomaly threshold, using $M+3 \sigma$, for all northwest Montana water samples combined. These eight, plus one additional sample having $12.90 \mathrm{ppb}$ uranium, are all listed in Appendix $\mathrm{C}-1$ as waters analyzed by delayed-neutron counting (DNC). Three of these anomalous uranium concentrations are in spring waters which apparantly emanate from Precambrian Belt metasedimentary rock (Plate I). The water from sample location No. 303365 (LASL) was collected $29 \mathrm{~km}$ northwest of Kalispell (Lat. $48^{\circ} 13^{\circ} 26^{\prime \prime}$, Long. $\left.114^{\circ} 26^{\prime} 00^{\prime \prime}\right)$. Agricultural activity was noted on the field data form at this location, but contamination from fertilizers, or other sources which might cause the high uranium concentration ( $31.40 \mathrm{ppb})$, is not known. A sediment sample taken at this same location, and described in the following 
section, measured $16.60 \mathrm{ppm}$ uranium, which is greater than three standard deviations above the mean for all of the sediment samples combined. The combination of anomalous uranium in both the water and sediment samples collected at this site might well warrant additional investigation. The two other anomalous spring waters (LASL Nos. 303761 and 303778) were collected at separate locations, each approximately $45 \mathrm{~km}$ west of Kalispell. Sample location No. 303761 (25.20 ppb uranium) is situated just north of Fisher River (Lat. $48^{\circ} 07^{\prime} 54^{\prime \prime}$, Long. $114^{\circ} 55^{\prime} 02^{\prime \prime}$ ). The site is shown on Plate $I$ as being Quaternary alluvium (possibly underlain by Precambrian Ravalli quartzite or argillite). A large fault trending to the north and northwest is mapped just west of the location. No possible sources of contamination or other abnormal conditions were noted on the field data form for this location. In the Pleasant Valley Creek drainage, about $7 \mathrm{~km}$ north of the location just mentioned, spring water from location No. 303778 was collected in an agricultural area on the north side of the valley (Lat. $48^{\circ} 11^{\prime} 27^{\prime \prime}$, Long. $114^{\circ}$ 55'21"). This site is also mapped on Plate I as covered by Quaternary alluvium and is probably underlain by Precambrian Ravalli metasedimentary bedrock. The fault described as passing to the west of location No. 303761 , discussed above, passes just to the east of location No. 303778 . It is concelvable that both springs are actually closer to the fault than indicated on the geologic base map (PIate I), and, if so, they may be reflecting mineralization associated with the fault. Sediment samples collected at these two locations do not show corresponding high uranium contents.

Three stream water samples were found to contain more than $14.25 \mathrm{ppb}$ uranium. Two of these samples (LASL Nos. 304722 and 304724 ) were collected in a single drainage, a tributary of Wolf Creek, located approximately $55 \mathrm{~km}$ west of Kalispell (Lat. $48^{\circ} 16^{\prime} 31^{\prime \prime}$, Long. $115^{\circ} 03^{\prime} 23^{\prime \prime}$ and Lat. $48^{\circ} 16^{\prime} 05^{\prime \prime}$, Long. $115^{\circ} 02^{\prime} 10^{\prime \prime}$, respectively). This tributary drains the western slope of Surprise Hill, which is mapped on Plate I as Precambrian Pritchard quartzite. Location No. 304724 (22.00 ppb uranium) is located $\sim 2 \mathrm{~km}$ upstream from No. 304722 ( $19.80 \mathrm{ppb}$ uranium). Agricultural activity was noted in the vicinity of both of these sample locations, but actual contamination due to the use of uranium-rich phosphate fertilizers, or other causes, was not confirmed. It is also notable that $\sim 5 \mathrm{~km}$ to the northeast, on Little Wolf Creek, stream water samples taken at location Nos. 304737 and 304739 also have somewhat higher uranium concentrations ( 5.48 and $5.98 \mathrm{ppb}$ uranium respectively) than other 
surface waters in the area. Little Wolf Creek drains the northern slopes of Surprise Hill, as well as mountainous areas to the north and east. The third stream water sample (No. 303381) having an anomalous concentration of uranium (19.80 ppb) was collected from a small easterly flowing stream at Kila (Lat. 48 $07^{\prime} 1^{\prime \prime}$ ", Long. $\left.114^{\circ} 28^{\prime} 05^{\prime \prime}\right)$. The sample was collected in an area mapped as Quaternary alluvium near its contact with the Precambrian Sireh limestone and dolomite (Plate I). Again, agricultural activity was noted at this location, but none of the other field data appear unusual.

Using the mean plus three standard deviations to define the anomaly threshold, two natural pond water samples are found to have anomalous uranium concentratons. One is from a pond located just below Lake Rogers (No. 303905, Lat. $48^{\circ} 03^{\prime} 47^{\prime \prime}$, Long. $\left.114^{\circ} 36^{\prime} 54^{\prime \prime}\right)$. This site is described on the field data form as being a muddy, stagnant pond, but no contamination is noted. The geology here is mapped as Quaternary glacial material and it is probably underlain at depth by Precambrian quartzite and/or argillite (Ravalli $\mathrm{fm}$ ). The measured uranium concentration of $23.50 \mathrm{ppb}$ may be partly a result of evaporative concentration. Also, the specific conductance of 605 mhos/cm measured at the site is somewhat higher than nomal for this area. The second anomalous natural pond water sample, No. 303361 (Lat. $48^{\circ} 10^{\prime} 42^{\prime \prime}$, Long. 114 21'50"), has the highest measured uranium concentration of any water sample collected in this survey, $(173.60 \mathrm{ppb})$. The sample location is $4 \mathrm{~km}$ southwest of Kalispell and just north of Foy Lake. The surface geology at the location is mapped as Quaternary glacial material (underlain by Precambrian Piegan metasedimentary bedrock). Contamination due to urbanization is indicated on the field data form, but even more significant is the very high specific conductance of the water, $>5000 \mu \mathrm{mhos} / \mathrm{cm}$, which appears to be the key to explaining the high uranium content. Note that the specific conductance listed in Appendix C is simply $5000 \mu \mathrm{mhos} / \mathrm{cm}$, not $>5000$ as it should be. Normally, the LASL-furnished conductivity meters can measure to 50,000 umhos/cm, using a xl0 range extender insert, but in this case the field notes indicate that the sampler did not bring along the necessary part to make the higher reading. Considering the urban location of the pond, its high specific conductance, and the absence of other high uranium concentrations nearby, the measured uranium content in the water from this site is probably less significant than it first appears. However, a follow-up investigation to determine the uranium source here would certainly seem appropriate. 
There are no other anomalously high concentrations of uranium (using the $M+3 \sigma$ cutoff) in water samples from this area of Montana. However, there is a general trend of increased uranium concentrations (higher background level) in waters sampled in proximity to and south-southeast of the Vermiculite Mountain pluton, east of Libby. These locations are nearly all underlain by Precambrian Wallace metasedimentary rocks (undifferentiated argillites, dolomites, and limestones). Structurally, the area includes a large northwest-trending fault, roughly paralleling the Fisher River Valley. West of the primary fault is a synclincal fold, faulted along its northwesttrending axis. The significance of the relatively high uranium concentrations in the waters of this area is not known.

VII. STATISTICAL AND EMPIRICAL EVALUATION OF THE SEDIMENT DATA

The following section presents basic statistical data for the uranium analyses of waterborne sediment samples from northwestern Montana. There were a total of 1725 locations sampled for sediment in the survey area, and the statistical results, by source type, are summarized in Table $V$, below.

T'ALE V

SUMMARY OF URANIUM DATA FOR SEDIMENT SAMPLES COLLECTED IN NORTHWEST MONTANA

\begin{tabular}{|c|c|c|c|c|c|c|}
\hline Source & \multicolumn{2}{|c|}{ Treatment } & No. & $\begin{array}{l}\text { Range } \\
\text { (ppm) }\end{array}$ & $\begin{array}{l}\text { Mean } \\
\text { (ppm) }\end{array}$ & $\begin{array}{l}\text { Standard } \\
\text { Dev. (ppm) }\end{array}$ \\
\hline All sediment & $\begin{array}{l}\text { Dried } \\
\text { Sieved }\end{array}$ & $\begin{array}{l}\leq 100^{\circ} \mathrm{C} \\
-100 \text { mesh }\end{array}$ & 1725 & $0.50-52.20$ & 4.56 & 3.25 \\
\hline Wet stream sediment & $"$ & " & 1542 & $0.50-52.20$ & 4.56 & 3.11 \\
\hline Dry stream sediment & $"$ & $"$ & 87 & $0.80-17.60$ & 3.86 & 2.28 \\
\hline $\begin{array}{l}\text { Wet natural pond } \\
\text { sediment }\end{array}$ & n & $"$ & 41 & $1.40-26.00$ & 5.99 & 5.63 \\
\hline Wet spring sediment & $"$ & $"$ & 38 & $1.40-33.90$ & 5.19 & 6.30 \\
\hline $\begin{array}{l}\text { Wet artificial pond } \\
\text { sediment }\end{array}$ & $"$ & " & 14 & $2.10-6.20$ & 3.52 & 1.21 \\
\hline Dry spring sediment & $"$ & $"$ & 2 & $1.90 \& 2.60$ & -- & -- \\
\hline $\begin{array}{l}\text { Dry natural pond } \\
\text { sediment }\end{array}$ & $"$ & " & 1 & 2.40 & - & -- \\
\hline
\end{tabular}


Included in this total are samples from 1542 wet streams, 87 dry streams, 41 wet natural ponds, 38 wet springs, 14 wet artificial ponds, 2 dry springs, and 1 dry natural pond. The uranium concentration for each individual sediment sample is given in Appendix D, where it should be noted that Type 99 designates the dry spring samples. An explanation of the designators used for all other sample types collected is given on the last page of Appendix E.

A.ll of the sediment samples were analyzed by DNC as described in Appendix A. The measured uranium contents range from a low of $0.50 \mathrm{ppm}$ to a high of $52.20 \mathrm{ppm}$. The mean uranium concentration for all of the samples combined is $4.56 \mathrm{ppm}$, and the stanciard deviation from the mean is $3.25 \mathrm{ppui}$. Statistical distributions, both for raw uranium data and log uranium data for all of the samples combined and for the individual groups of samples by source type, are presented as histograms in Appendix B-II. The sample locations are again designated by number (with the first two digits dropped) on the overlay of Plate II, and the uranium concentrations found in the various samples are plotted graphically on the overlay of Plate IV.

For purposes of the following discussion, an anomaly threshrid value of $M$ $+3 \sigma(14.31 \mathrm{ppm})$ as determined for all samples combined is used. On this basis, there are 28 samples which can be considered anomalous. Twenty of these are from wet streams, four are from wet natural ponds, three are from wet springs, and one is from a dry stream. For the most part, these anomalous samples occur at isolated locations scattered throughout the survey area. Consequently, only those locations where an obvious clustering of high values occur on Plate IV will be discussed here. This does not mean that the other high concentrations are insignificant, but only that their significance is difficult, if not impossible, to establish on the basis of available data. Except where there is evidence of contamination, follow-up studies at these isolated high uranium locations, including geologic and geochemical checks, might prove worthwhile. These isolated high-uranium sediment locations are listed in Table VI at the end of this section, along with some brief comments about each.

There are two sediment samples from sites located near Kilbrannon Lake, approximately $14 \mathrm{~km}$ north of Troy, which have anomalous uranium contents. Sample location No. $303860^{\circ}$ (Lat. $48^{\circ} 35^{\prime} 50^{\prime \prime}$, Long. $115^{\circ} 53^{\prime} 08^{\prime \prime}$ ) is a wet spring having sediment with a measured uranium content of $33.9 \mathrm{ppm}$. Approximately $1.5 \mathrm{~km}$ south of the spring is location No. 303859 (Lat. $48^{\circ}$ 
35'12", Long. $\left.115^{\circ} 52^{\prime} 48^{\prime \prime}\right)$, a stream providing sediment with a uranium content of $20.2 \mathrm{ppm}$. These two locations are on separate tributaries, both of which enter O'Brian Creek a few kilometers to the south. The geology at both sites is mapped on Plate I as Precambrian Ravalli quartzite and argiliite, undifferentiated. A northwest-trending fault is projected to pass just to the southwest of both locatjons. Furthermore, uranium mineralization is indicated in the literature at a iocation approximately $10 \mathrm{~km}$ downstream. $^{29}$ An adequate description f this mineralization was not found; however, in this area it is probable that it is associated with fissure filling veins, possibly along the above mentioned fault. The anomalous uranium content of sediments from location Nos. 303860 and 303859, upstream, may also be caused by local mineralization along the fault zone, but a field check is needed for verification of this.

A second stream drainage where a pair of high uranium concentrations in sediment occur is on Keeler Creek, near the western boundary of the study area. Samples taken at location Nos. 303990 (Lat. $48^{\circ} 20^{\prime} 13^{\prime \prime}$, Long. $115^{\circ}$ $57^{\prime} 36^{\prime \prime}$ ) and 303991 (Lat. 48 $20^{\prime} 04^{\prime \prime}$, Long. $115^{\circ} 58^{\prime} 36^{\prime \prime}$ ) have measured uranium contents of $11.9 \mathrm{ppm}$ and $22.7 \mathrm{ppm}$ respectively. Possible contamination due to logging activity near site No. 303990 was noted as a comment on the field data form (and listed in the appropriate column of the data listing as being a possible source of contamination "other" than that for which a specific code number is provided). The specific conductance of the water at these sites is very low, 17 and $10 \mu m h o s / c m$ respectively, and the $\mathrm{pH}$ is also quite low, being reported as $5.2 \mathrm{pH}$ units at both sites. The low $\mathrm{pH}$ of the water would indicate a slight 1 y enhanced capacity to dissolve and transport soluble uranium, and thus the low uranium content of the water at both sites (0.1 ppb) and the high uranium content in the sediment might be explained by the uranium being bound up (possibly in resistate minerals) in the sediment. The lithology at both sites is mapped on Plate I as Precambrian Ravalli fm, quartzite and argillite, undifferentiated. Additionally, there are numerous quartz veins filling fractures in this general area and they too might contribute a substantial quantity of resistate detritus into the local drainages. It is also probable that the vein material contains relatively high uranium mineralization compared to the country rock.

Granite Creek, which flows to the northeast from Big Loaf Mountain, is iocated approximately $15 \mathrm{~km}$ south-southwest of Libby. The core of Big Loaf 
Mountain is mapped on Plate $I$ as a granite stock, and several mines or prospects are indicated on the topographic maps of the area. Gold, silver, and lead minerals have been mined from vein deposits in this vicinity (see No. 13 on Fig. 5). Sediment samples from location Nos. 304643 (Lat. 48 $16^{\prime} 49^{\prime \prime}$, Long. $\left.115^{\circ} 41^{\prime} 20^{\prime \prime}\right), 304645$ (Lat. $48^{\circ} 17^{\prime} 22^{\prime \prime}$, Long. $115^{\circ} 40^{\prime} 43^{\prime \prime}$ ), 304646 (Lat. $48^{\circ} 17^{\prime} 26^{\prime \prime}$, Long. $115^{\circ} 40^{\prime} 26^{\prime \prime}$ ), and 304647 (Lat. $48^{\circ} 17^{\prime} 45^{\prime \prime}$, Long. $115^{\circ}$ $\left.39^{\prime 4} 40^{\prime \prime}\right)$ have measured uranium contents of $10.5,28.2,7.7$ and $10.9 \mathrm{ppm}$ respectively. The water data from these sites are similar to those from Keeler Creek discussed above (low pH, conductivity, and uranium), and it is probable that the uranium in the Granite Creek sediment is also tied up in resistate minerals. The possibility of contamination from recreational activity in Granite Creek Canyon was noted on the field data forms, but its true significance is unknown.

Sample No. 304165 (Lat. $48^{\circ} 24^{\prime} 34^{\prime \prime}$, Long. $115^{\circ} 21^{\prime} 40^{\prime \prime}$ ), collected in a stream drainage on the southeast flank of Vermiculite Mountain approximately $14 \mathrm{~km}$ east-northeast of Libby, had a measured uranium content of $15.8 \mathrm{ppm}$. Since uranium mineralization was noted in the literature at other places on Vermiculite Mountain (Rainy Creek District), this high content of uranium in sediment might be indicative of local mineralization upstream. The only suspect source of contamination noted at location No. 304165 is from logging activity. Samples collected elsewhere on Vermiculite Mountain (including a dry stream sediment sample from location No. 304681 ( $4.0 \mathrm{ppm} \mathrm{U}$ ), in Kennedy Gulch, downslope (?) from an intrusive dike containing some radioactive minerals) generally contain the normal range of uranium for the whole study area.

Three stream sediment samples collected from Warland Creek, approximately $25 \mathrm{~km}$ northeast of Libby, all have uranium concentrations notably higher than the average for this area, although none were above the anomaly threshold of $M$ $+3 \sigma$. The samples from location Nos. 304893 (Lat. $48^{\circ} 30^{\prime} 10^{\prime \prime}$, Long. $115^{\circ}$ $09^{\prime} 57^{\prime \prime}$ ) with $10.8 \mathrm{ppm}$ uranium, 304894 (Lat. $48^{\circ} 30^{\prime} 19^{\prime \prime}$, Long. $115^{\circ} 12^{\prime} 40^{\prime \prime}$ ) with $10.7 \mathrm{ppm}$ uranium, and 304895 (Lat. $48^{\circ} 30^{\prime} 12^{\prime \prime}$, Long. $115^{\circ} 1^{\prime} 5^{\prime \prime}$ ) with $11.3 \mathrm{ppm}$ uranium were collected along a $6 \mathrm{-km}$ stretch of the creek. Possible agricultural contamination was noted at location Nos. 304894 and 304895 , both downstream from No. 304893. Bedrock along Warland Creek is mapped on Plate I as Precambrian Pritchard quartzite. The stream channel follows along the eastward extension of a long fault which trends to the west and northwest 
across the Purcell Mountains. The corresponding bater samples from Warland Creek had relatively low uranium concentrations $(<0.42 \mathrm{ppb})$. The $\mathrm{pH}$ and conductivity readings were typical for wate:s in this general region ( $\mathrm{pH}$ between 6.1 and $6.6 \mathrm{pH}$ units; conductivit; <100 $\mu \mathrm{mhos} / \mathrm{cm}$ ). The bottom sediment at each location is described as gravel, and there is no indication that the sediment from any of these loca'ions contained excessive organic material (which might increase the uranium contents somewhat, as described previously).

Two sediment samples collected in the Dry Fork Creek drainage, approximately $35 \mathrm{~km}$ east of Libby, have anomalous uranium concentrations. The sample from location No. 304747 (Lat. $48^{\circ} 22^{\prime} 01^{\prime \prime}$, Long. 115 $02^{\prime} 16^{\prime \prime}$ ) had a measured uranium content of $17.60 \mathrm{ppm}$. This sample was collected from a dry stream bed which drains to the southwest into Dry Fork Creek. Approximately 2 km to the northwest of this site, on Dry Fork Creek itself, a wet stream sediment sample having $16.6 \mathrm{ppm}$ uranium was collected at location No. 304748 (Lat. $48^{\circ} 22^{\prime} 28^{\prime \prime}$, Long. $115^{\circ} 03^{\prime} 4^{\prime \prime}$ ). The geology at both sites is mapped as Quaternary glacial deposits (Plate I), probably overlying Precambrian Pritchard quartzite. A north-trending fault is projected to pass very close to location No. 304747 and just to the east of No. 304748. Detritus from vein material weathered from fissures within the fault zone may account for the high uranium concentrations at these two locations. However, a field check is needed for confirmation.

Three streams draining a mountainous area north and northwest of Dahl Lake (about $40 \mathrm{~km}$ west of Kalispell) provide sediment samples with relatively high uranium contents. A sediment sample taken from a stream which flows directly into Dahl Lake from the north (location No. 304712, Lat. 48 $09^{\circ} 45^{\prime \prime}$, Long. $\left.114^{\circ} 48^{\prime} 35^{\prime \prime}\right)$, shows a uranium content of $15.0 \mathrm{ppm}$. About $8 \mathrm{~km}$ to the northwest, a stream sediment sample collected on a tributary of Pleasant

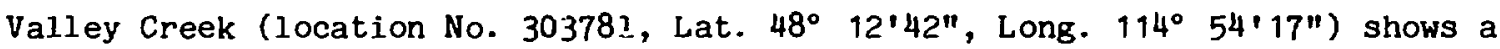
uranium content of $14.7 \mathrm{ppm}$. About $4 \mathrm{~km}$ north of this location, on Coniff Creek, there are three additional sample locations where the uranium concentrations in stream sediment are notably above average for this general

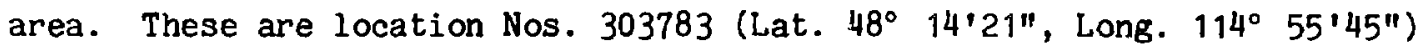
with 13.9 ppm uranium; 303784 (Lat. $48^{\circ} 14^{\prime} 67^{\prime \prime}$, Long. $114^{\circ} 52^{\prime} 47^{\prime \prime}$ ) with 10.8 ppm uranium; and 303785 (Lat. $48^{\circ} 14^{\prime} 14^{\prime \prime}$, Long. $114^{\circ} 56^{\prime} 19^{\prime \prime}$ ) with $10.8 \mathrm{ppm}$ uranium . All of these locations are in drainages originating on Pleasant 
Valley Mountain, an anticlinal structure mapped as Precambrian Ravalli quartzite and argillite, undifferentiated (Plate I). Possible contamination due to agricultural activity was noted at all five locations. Even so, the source of uranium in these sediment samples is again most likely mineralized veins cutting the local country rock, but this cannot be verified without a field check.

Approximately 15 to $20 \mathrm{~km}$ west of Flathead Lake, along ;he southern boundary of the study area, there are four stream sediment sample locations which have notably high uranium concentrations (Plate IV). These locations, Nos. 303394 (Lat. $48^{\circ} 03^{\prime} 21^{\prime \prime}$, Long. $14^{\circ} 25^{\prime} 36^{\prime \prime}$ ) with 10.8 ppm uranium; 303396 (Lat. $48^{\circ} 01^{\prime} 55^{\prime \prime}$, Long. $114^{\circ} 24^{\prime} 44^{\prime \prime}$ ) with $15.7 \mathrm{ppm}$ uranium; 303397 (Lat. $48^{\circ}$ $00^{\prime} 51^{\prime \prime}$, Long. $114^{\circ} 24^{\prime} 15^{\prime \prime}$ ) with $13.4 \mathrm{ppm}$ uranium; and 303398 (Lat. $48^{\circ} 00^{\prime} 04^{\prime \prime}$, Long. $114^{\circ} 26^{\prime} 32^{\prime \prime}$ ) with $12.0 \mathrm{ppm}$ uranium, are located on Wild Bill Creek and a tributary which runs nearly parallel to it on the east. Both creeks originate on Blacktail Mountain and flow northward toward Smith Lake. On the southern slope of Blacktail Mountain, about $8 \mathrm{~km}$ southeast of Wild Bill Creek (just south of the map toundary), is a local mining area (Jumbo, Big Four, and Mosher mines) where lead, silver, and copper have been mined from northwesttrending veins that cut Precambrian Ravalli quartzite and argillite. ${ }^{12}$ Geologically, the Wild Bill Creek sample area is very similar to the mining area to the south. The lithology and structure shown on Plate I continue to the southeast through the mineralized area. It is possible that mineralized veins equivalent to those in the mining area also occur in the vicinity of Wild Bill Creek. If so, they could be the source of the increased uranium contents in sediment from that area. Possible contamination due to agricultural activity was noted at all locations except No. 303394, though it is doubtful that this is affecting appreciably the uranium content of the sediment sample. The $\mathrm{pH}$ and specific conductance values of the stream waters were all within normal ranges for this area, (i.e., $\mathrm{pH}<6.0$; conductivity between 20 and 530 jmhos $/ \mathrm{cm}$ ).

A sediment sample taken from a pond at location No. 303387 (Lat. $48^{\circ}$ $07^{\prime} 47^{\prime \prime}$, Long. $114^{\circ} 26^{\prime} 22^{\prime \prime}$ ), below Smith Lake (about $10 \mathrm{~km}$ downstream from the Wild Bill Creek locations), has a uranium content of $24.7 \mathrm{ppm}$. This location is described as being a marshy area, with the sediment being rich organic muck. The site is also described as being within a recreational area. The pH of the water is 6.5 , which is typical of this region, while the conductivity 
of $650 \mu \mathrm{mhos} / \mathrm{cm}$ is slightly above average. The water is described as algal. The high uranium content of the sediment at this location is quite possibly the result of adsorptive concentration in the organic-rich sediment.

Approximately $10 \mathrm{~km}$ due north of Smith Lake is a spring, at sample location No. 303365 (Lat. $48^{\circ} 13^{\prime} 26^{\prime \prime}$, Long. $114^{\circ} 26^{\prime} 00^{\prime \prime}$ ), which has anomalous uranium in both the sediment $(16.6 \mathrm{ppm})$ and the water $(31.4 \mathrm{ppb})$. As mentioned in the previous section, this is the only location in the survey area having high concentrations of uranium in both the water and sediment samples. The location is along a fault contact between Precambrian Lower Piegan argillite and/or quartzite and Precambrian Ravalli, quartzite and argillite, undifferentiated (Plate I). The site is described as densely vegetated with nearby agricultural activity. The spring sediment is described as a gray mud, and an above-average content of clays and/or organics, if present, could account for the high uranium content of the sediment. The $\mathrm{pH}$ (7.2 pH units) and conductivity $(625 \mu \mathrm{mhos} / \mathrm{cm})$ are slightly higher than usual for the area, but still not abnormal, particularly for groundwater. The temperature of the water was $13.2^{\circ} \mathrm{C}$. It is also possible that uranium mineralization along the fault (at an unknown depth) is being reflected at the surface here in both the water and sediment. A follow-up investigation at this site and along the northwest-trending fault is definitely suggested by these data.

East of Flathead Lake, in Flathead Valley, there are seven stream locations with anomalous, or notably high, uranium concentrations in the sediment. Each of the streams have their headwaters in the Swan Range to the east. The sample location Nos. 303502 (Lat. $48^{\circ} 00^{\prime} 38^{\prime \prime}$, Long. $113^{\circ} 55^{\prime} 38^{\prime \prime}$ ) through 303506 (Lat. $48^{\circ} 03^{\prime} 2^{\prime} 7^{\prime \prime}$, Long. $113^{\circ} 58^{\prime} 10^{\prime \prime}$ ) and 303509 (Lat. $48^{\circ}$ 06'21', Long. $113^{\circ} 56^{\prime} 31^{\prime \prime}$ ) are all shown on Plate $I$ as being in an area of alluvial cover. Their headwaters are in an area of Precambrian argillites and quartzites comprising the Grinnell and Appekuny formations. One small fault, trending to the northeast, is mapped near location No. 303509 on Wolf Creek. Possible contamination sources were not noted in the field data at any of these sites. The recorded pH ranges from 4.8 at location No. 303509 to 5.8 at No. 303503 , and the specific conductance of the waters is between $44 \mu \mathrm{mhos} / \mathrm{cm}$ at location No. 303504 and $88 \mu \mathrm{mhos} / \mathrm{cm}$ at No. 303505. The uranium content of the sediment from these locations ranges from a lo: of $5.0 \mathrm{ppm}$ at location No. 303506 to $40.7 \mathrm{ppm}$ at No. 303504 , on Schmidt Creek. The source of the uranium 
in the sediments of these streams is unknown, but an examination of the geology in the area of their headwaters in the Swan Range is certainly called for. The high uranium content of the pond sediments from location Nos. 303322 (Lat. $48^{\circ} 09^{\prime} 3^{\prime \prime}$, Long. $114^{\circ} 04^{\prime} 4^{\prime \prime}$ ) with $26.0 \mathrm{ppm}$ uranium and 303337 (Lat. $48^{\circ} 05^{\circ} 35^{\prime \prime}$, Long. $\left.114^{\circ} 04^{\circ} 23^{\prime \prime}\right)$ with $15.1 \mathrm{ppm}$ uranium might also be a reflection of mineralization farther east in the Swan Range.

A group of four sediment samples from locations along Emery Creek and its tributaries, which flow generally south from Desert Mountain into Hungry Horse Reservoir, has uranium contents above the average for this area even though not anomalous, using the $M+30$ threshold. These locations, Nos. 303093

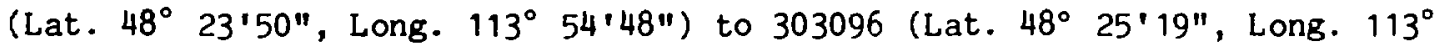
56'06"), have uranium contents ranging from $5.6 \mathrm{ppm}$ at No. 303093 to $9.8 \mathrm{ppm}$

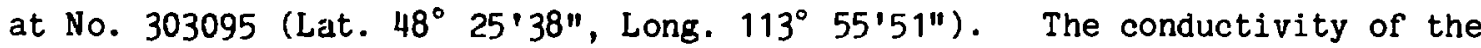
water reported at location No. 303095 (224 $\mu$ mhos/cnil) is 5 to 10 times higher than reported at the other sites, but it is unlikely that this would cause an increase in the uranium content of the sediment. The corresponding water samples from these locations all have uranium concentrations below $0.2 \mathrm{ppb}$. Enery Creek follows a fault separating Precambrian Grinnell argillite on the east from Missoula argillite and quartzite on the west. Uranium mineralization associated with the fault is again a distinct possibility in this area.

The last remaining locality in which several sediment samples from a single drainage system within the survey area have notably high uranium concentrations is along Yakinikak Creek, about $25 \mathrm{~km}$ east of Eureka and $10 \mathrm{~km}$ south of the Canadian border. The geology in this area is complex, with three Precambrian formations, the Roosville, Phillips, and Kintla, exposed. Jumerous faults also occur in the vicinity and one, which trends northward, is followed by the two headwater branches of Yakinikak Creek. At these sample locations, Nos. 304814 (Lat. $48^{\circ} 54^{\prime} 49^{\prime \prime}$, Long. $114^{\circ} 37^{\prime} 42^{\prime \prime}$ ) to 304819 (Lat. $48^{\circ} .53^{\prime} 20^{\prime \prime}$, Long. $\left.114^{\circ} 41^{\prime} 00^{\prime \prime}\right)$, the uranium in sediment ranges from a high of $15.1 \mathrm{ppm}$ (No. 304814) to a low of $8.7 \mathrm{ppm}$ (No. 304819). No possible contaminants are indicated at any of these locations, and the water $\mathrm{pH}$ and conductivity values are normal for the region. Here again, detritus from mineralized veins along the fault is indicated as the probable source of the higher uranium concentrations in the stream sediment. A follow-up field reconnaissance in the upper reaches of Yakinikak Creek might verify both the source and extent of the mineralization in this drainage. 
In addition to the localities in northwestern Montana providing two or more sediment samples with noteworthy uranium content and discussed above, a number of others are found where only a single, isolate:. 1. igh-uranium sediment sample is in evidence. These latter sites are listed in Table VI, along with their location numbers and other relevant data.

\section{SUMMARY AND CONCLUSIONS}

Natural water and waterborne sediment samples were collected at a density of about 1 per $10 \mathrm{~km}^{2}$ over a $17000-\mathrm{km}^{2}$ area in Lincoln and Flathead Counties, northwest Montana. Sample collection was carried out during a six-week period between mid-May and late June 1976. A total of 1781 locations were sampled, with 1684 water samples and 1725 sediment samples, for a total of 3409 samples in all being collected. All of the water samples were filtered through a $0.45-\mu$ membrane filter and acidified to a $\mathrm{pH}$ of $u$ with $8 \mathrm{~N}$ reagent-grade $\mathrm{HNO}_{3}$. All of the sediment samples were dried at $\leq 100^{\circ} \mathrm{C}$ and sieved to retain the -100 mesh fraction for analysis.

Geographically, northwest Montana is dominated by northwest-trending ranges and intermontane valleys. The area is heavily forested, and streams and rivers, fed primarily by winter snows, are numerous. The temperate climate is classified as a modified maritime type, and precipitation is fairly uniformly distributed throughout the year. Geologically, Precambrian Belt metasediments are the predominant bedrock in the area, and these are complexly folded and faulted. Igneous dikes and stocks, of ten related to major structural features, are common. Quartzitic replacement veins filling fractures and fissures along fault zones and fold axes are also common, particularly in the western part of the survey area. Gold, silver, zinc, and copper have beem mined from local placers and vein deposits at a number of places. Vermiculite and associated non-metals are currently mined from a small intrusive pluton in Lincoln County. At least five minor occurrences of radioactive mineralization are noted in the literature on the area, and all are associated with mesothermal or epithermal veins in western Lincoln County.

The water samples were analyzed either by fluorometry (those $\leq 10 \mathrm{ppb}$ uranium) or by DNC (those $>10 \mathrm{ppb}$ uranium). The measured uranium concentrations in the waters range from $<0.2 \mathrm{ppb}$, the lower detection limit of the fluorometric method as used at the LASL at the time, to $173.6 \mathrm{ppb}$. The highest uranium content in water is in a natural pond sample having the 
TABLE VI

LOCATION NUMBERS AND RELEVANT DATA FOR ISOLATED HIGH AND/OR

ANOMALOUS SEDIMENT SAMPLE, NORTHWESTERN MONTANA

\begin{tabular}{|c|c|c|c|c|c|c|c|c|c|}
\hline $\begin{array}{l}\text { LOCATION } \\
\text { NOL } \\
\end{array}$ & LATITUDE & LOMGITUDE & $\begin{array}{l}\text { TOTAL } \\
\text { UFAMIIM } \\
\text { PPQDI } \\
\end{array}$ & 래 & 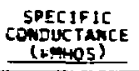 & DRAIHAGE: & GEOLOGY & GoNIAMINANIS & $\begin{array}{l}\text { PROBABEE } \\
\text { URANIUM } \\
\text { SOURCE. }\end{array}$ \\
\hline 305102 & $48^{\circ} 18^{\prime} 02^{\prime}$ & $115^{\circ} 4 y^{\prime} 31^{\circ}$ & 44.2 & 5.9 & 98 & Riverside Crean & LiNMAPPED & $m a$ & Unknowir \\
\hline 303197 & $48^{\circ} 36^{\prime} 59^{\prime \prime}$ & $114^{\circ} 17^{\prime} 34^{\circ}$ & 17.7 & 6.5 & E.5 & Talbutare of HIG CREEK & PEK, NU FAULT & $N / A$ & $\begin{array}{l}\text { VEIN DETRITUS FROM } \\
\text { FAULT IONE }\end{array}$ \\
\hline 303245 & $48^{\circ} 15^{\prime} 5 n^{*}$ & $114^{\circ} 06^{\circ}+40^{\prime \prime}$ & 22.1 & 4.5 & 40 & $\begin{array}{l}\text { UWMAMED STREAM ELOWING } \\
\text { WEST OFF BLAIN HOUNTAIN }\end{array}$ & PEG, IW FAML: & $1 / 4$ & $\begin{array}{l}\text { VEIR DETRITUS FRIM } \\
\text { FAULT ZONE }\end{array}$ \\
\hline 303338 & $48 \cdot 01 \cdot 38=$ & $14^{\circ}\left(13^{\prime} 4 F^{\prime \prime}\right.$ & 11.5 & $E .=$ & PF.S & $\begin{array}{l}\text { UWNAMED CREEK FLOWINIS } \\
\text { WEST INTO F LATHEAD LAKE }\end{array}$ & $\begin{array}{l}\text { PERU, H I NE } \\
\text { FAULTS }\end{array}$ & nürstC HL tURE & $\begin{array}{l}\text { YEIN DI IRITUS FROM } \\
\text { FAULT ZONE }\end{array}$ \\
\hline 303420 & $18^{\circ} 28^{\prime} 28^{\prime}$ & $114^{\circ} 10^{\circ} 56^{\circ}$ & 17.3 & 6.3 & Es & HeADWATERs IlaskillL CREek & $O G-P E_{G}$ & RECREATION & UNKMOWN \\
\hline 303483 & $48^{\circ} 411^{\prime} 12^{\circ}$ & $114^{\circ} 46^{\circ} 27^{\circ}$ & 15.7 & 5.3 & $15 \pi$ & $\begin{array}{l}\text { LWNAMED CAEEK SOUTHEAST } \\
\text { OF TFICKEY LAKE }\end{array}$ & PEG, NW FAULT & $N / A$ & VEIN DETRITUS (?) \\
\hline 303649 & $48^{*} 28^{\prime} 30^{\circ}$ & $115 \cdot 31 \cdot 0 !^{*}$ & 11.6 & f.k & 118 & Iaibutary of Pipe Creek & PEW, HH FAULT & AgRiculture & VEIN EETRITUS \\
\hline 303728 & $48^{\circ} 06^{\prime} 23^{\prime \prime}$ & $115^{\circ} 10^{\circ} 49^{\circ}$ & 12.7 & $E . j$ & 110 & $\begin{array}{l}\text { WWHNMEd CREEK nORTH OF } \\
\text { HORSE SHOE LAKE }\end{array}$ & $\begin{array}{l}\text { AG-PEW-PESP, } \\
\text { FAULTS }\end{array}$ & $H / A$ & VEIN DETRITUS \\
\hline 373750 & $48^{\circ} 06^{\prime} 25^{\prime}$ & $114^{\circ} 52^{\prime}$ of ${ }^{\prime}$ & 14.0 & 6.1 & 125 & $\begin{array}{l}\text { WNMAMED TRIBUTART OF } \\
\text { FISHER RIVER }\end{array}$ & $\begin{array}{l}\text { Gg-pEAy, } \\
\text { NanticLime }\end{array}$ & AGRICUL TURE & VEIM DETRITUS (?) \\
\hline 303759 & $48^{\circ} 02^{\prime} 00^{\prime \prime}$ & $114^{\circ} 55^{\prime} 1 y^{*}$ & 16.7 & - & - & meGregor CREex & DG-PERU & $N / A$ & UNKHOWN \\
\hline 303770 & $48^{\circ} 044^{\prime} 00^{\prime \prime}$ & $115^{\circ} 02^{\prime} 42^{\prime}$ & 13.3 & $6 .+$ & 223 & $\begin{array}{l}\text { LIMMAMED PQND OH STREAM } \\
\text { WORTH OF PHOMPSON LAKES }\end{array}$ & PEW, NH FAULT & $\because / A$ & $\begin{array}{l}\text { HIGH ORGANIC CON- } \\
\text { TENT ?? VI VEIN } \\
\text { DETRITUS (?) }\end{array}$ \\
\hline 303816 & $48^{\circ} 37^{\prime} 33^{\prime}$ & $114^{\circ} 31^{\prime} 34^{\prime}$ & 15.3 & $3 . n$ & SOS & IRIBUTARY OF SWIFT CAEEK & $\begin{array}{l}\text { PEG-PEAP-PES, } \\
\text { WW FAULT }\end{array}$ & Pecreation & VEIN DETRITUS \\
\hline 303824 & $48^{\circ} 34^{\prime} 40^{\circ}$ & $114^{\circ} 33^{\prime} 37^{\prime}$ & 15.1 & 6.5 & 173 & Pond mear lazy CREex & QG, MH FAULT & RECREATION & 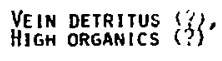 \\
\hline 303837 & $48^{\circ} 43^{\prime} ? y^{\prime}$ & $114^{\circ} \div 3 \cdot 46^{\circ}$ & $5,2.2$ & $E .0$ & $2 \mathrm{~F} \theta$ & Stillmater Caeek & peg, mil fault & Recreation & VEIN DETRITUS \\
\hline 303907 & $48^{\circ} 02^{\prime} 35^{\circ}$ & $114^{*} 39^{\circ} 01^{*}$ & 25.2 & b. 3 & Ino & $\begin{array}{l}\text { SPAIMG SOUTHMEST OF LAKE } \\
\text { ROGER5 }\end{array}$ & 舦-PERU, & AGRICULTURE & $\begin{array}{l}\text { MINERAL IZED GROUND } \\
\text { WATER ALONG FAULT } \\
\text { ZONE }\end{array}$ \\
\hline 303915 & $48^{\circ} 05^{\circ} 47^{\prime \prime}$ & $114^{\circ} 41^{\circ} 07^{\circ}$ & 13.2 & 6.4 & 33? & 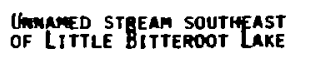 & Q GG & AGRICULTURE & UnKwown \\
\hline 303931 & $48^{\circ} 08^{\prime} 38^{\circ}$ & $114^{\circ} 34^{\circ} 33^{\circ}$ & 14.9 & 6.8 & $25 n$ & $\begin{array}{l}\text { LWNAMED STREAM ENTERIMG } \\
\text { LONE LAKE }\end{array}$ & $\begin{array}{l}\text { PES, NH \& HE } \\
\text { FAULTS }\end{array}$ & AgRICULTURE & VEIN DETRITUS \\
\hline 304031 & $48^{\circ} 38^{\prime} 19^{\prime \prime}$ & $115^{\circ} 43^{\circ} 23^{*}$ & 12.9 & 5.1 & 29 & Seventeen Mile Creek & PEW & Pecreation & VEIN DETRITUS (?) \\
\hline 304137 & $48^{\circ} 01^{\prime} 13^{\prime \prime}$ & $115^{\circ} 54^{\circ} 22^{\circ}$ & 15.8 & 5.5 & 26 & Ta1Butanar of ELK CREEK & PEW & LOGGING & VEIN DETRITUS (?) \\
\hline 304149 & $48^{\circ} 29^{\circ} 26^{\circ}$ & $115^{\circ} 30^{\circ} 50^{\circ}$ & 11.3 & 5.1 & 20 & Taidutani of Quartz Creek & $r_{G}-P E L$ & $M / n$ & VEIN DETRITUS (?) \\
\hline 304188 & $48^{\circ} 23^{\prime} 00^{\prime \prime}$ & $115^{\circ} 15^{\circ} 44^{*}$ & 12.5 & 5.7 & 117 & Buin Creek & PERU & $N / A$ & VEIW DETRITUS (?) \\
\hline 304198 & $\left.48^{\circ} 25^{\prime}\right) ?{ }^{\prime}$ & $115^{\circ} 12^{\circ} 38^{\circ}$ & 12.1 & 5.7 & 47 & Canyon Cr.EEK & PERU, NH fault & $N / A$ & VEIN DETRITUS \\
\hline 304652 & $48^{\circ} 42^{\prime} 41^{\prime}$ & $116^{\circ} 02^{\circ} 46^{\circ}$ & 12.2 & 6.0 & 43 & Pime 〔reek & 照-PEH, FALT & AgRICUL TURE & VEIN DETRITUS \\
\hline 304751 & $48^{\circ} 21^{\prime} 57^{\prime \prime}$ & $115^{\circ} 15^{\prime} 55^{*}$ & li.5 & 3.7 & 35, & Dunm CREEK & PERU & N/A & VEIN DETRITUS (?) \\
\hline 304833 & $48^{\circ} 44^{\prime} 22^{\prime \prime}$ & $114^{\circ} 23^{\prime} 10^{*}$ & 12.9 & 3.5 & 65 & Mopam Creek & PEPH, F FAULT & N/A & VEIN DETRITUS (?) \\
\hline 304911 & $48^{\circ} 16^{\prime} 13^{\prime}$ & $114^{\circ} 39^{\circ} 42^{\prime \prime}$ & 11.3 & 6.5 & 355 & Headmater logan Caeek & PES, ME FAULT & II/A & VEIH DETRITUS (?) \\
\hline
\end{tabular}

"As shom on appaophiate nims $Z^{*}$ smeEt.

b As shohin amd described on Plate $I$. 
highest specific conductance ( $>5000$ umhos) of any site sampled in northwestern Montana. There are 821 water samples with uranium contents <0.2 ppb, and, in order to treat the results statisifcally; these samples are arbitrarily assigned a value of $0.1 \mathrm{ppb}$. On this basis, the mean uranium value for all water samples combined is $0.66 \mathrm{ppb}$. After dropping the two or three highest values from each sample type (source) population, only the spring waters show a significantly higher mean uranium value ( $1.2 \mathrm{ppb})$ than that of all types combined. This greater average uranium content in groundwater corresponds to findings of other investigators in other areas. The results from the water samples do not directly define any of the five known or suspected uranium locations, but this can be explained by any one of several circumstances:

A. The known radioactive mineralization is quite localized and low grade.

B. The known radioactive minerals in the area are associated with quartzitic veins and are likely to be largely of primary type or bound up in resistates.

C. Water samples from the vicinity of the reported radioactive veins are typically several kilcmeters or more downstream.

D. Dilution of the sample waters by mixing with snowmelt or tributary stream waters from unmineralized areas would limit the extent of any local uranium haloes in northwestern Montana.

Nevertheless, the analysis of water samples did result in identification of several areas where above average uranium concentrations in the waters are clustered. A few of these localities appear to be good candidates for follow-up investigations.

All of the sediment samples collected in northwestern Montana were analyzed for total uranium, using DNC. The measured concentrations range from 0.5 to $52.2 \mathrm{ppm}$ and, taken together (all sources combined), have a mean uranium content of $4.56 \mathrm{ppm}$. Using an anomaly cutoff equivalent to the mean value plus three standard deviations $(M+3 \sigma), 28$ samples were found to be anomalous. For the most part, these anomalous samples come from isolated locations scattered throughout the survey area. There are, however, several local areas which have clusters of sediment samples with significantly higher than average uranium concentrations. In almost every case, the sediment samples having high concentrations of uranium are found to have come directly from, or very close to, major fault zones or fold axes. The association of 
the high uranium in sediment with structures which are often interlaced with veins indicates that vein detritus might well be the source of the uranium in the water-transported sediment. Furthermore, the generally low uranium content in the local waters would seen to support the premise that most of the uranium is bound up ir resistate gangue minerals, such as quartz, which are a major constituent or many veins in the area.

An areal evaluation of the sediment sample data from northwestern Montana indicates that there are several localities where sediments with above average uranium concentrations cluster. Field investigation along structural lineaments and near intrusive bodies upslope from these areas is suggested by the data as holding greatest promise.

\section{ACKNOWLEDGMENTS}

The author gratefully acknowledges the help and encouragement of the following groups and individuals without whose suppost this report would not have been possible: the LASL Analytical Chemistry Group, CMB-1, who performed the fluorometric analyses of the water samples; the LASL Research Reactor Experiments Group, $\mathrm{P}-2$, who performed the delayed neutron counting of the sediment samples; the LASL Energy Systems and Statistics G،oup, Q-12, who were resfonsible for data storage and control, statistical treatments, and graphic plots. Special thanks goes to the following members of the LASL Applied Geochemistry Group, I-5: Patricia O'Rourke and Judy Wilkinson for their help in editing and typing the text, John Tubb for preparing all of the figures and piates included in the report, and Robert R. Sharp, Ir. for his critical review and helpful suggestions. 
1. Sharp, R. R., Jr. and Aamodt, P. L., 1976, Uranium concentrations in natural waters, South Park, Colorado, GJBX-28(76), US ERDA, Grand Junction, $\mathrm{CO}, 34 \mathrm{~F}$.

2. Sharp, R. R., Jr., 1976, Hydrogeochemical and stream sediment survey of the National Uranium Resource Evaluation program, the Rocky Mountain states of New Mexico, Colorado, Wyoming, and Montana and the state of Alaska, April-June 1975, GJBX-19(76), US ERDA, Grand Junction, C0, 48 p.

3. Sharp, R. R., Jr. and Morris, W. A., 1976, Hydrogeochemical and stream sediment survey of the National Uranium Resource Evaluation program, the Rocky Mountain states of New Mexico, Colorado, Wyoming, and Montana and the state of Alaska, July-September 1975, GJBX-25(76), US ERDA, Grand Junction, $\mathrm{CO}, 47 \mathrm{p}$.

4. Sharp, R. R., Jr. and Aamodt, P. L., 1976, Hydrogeochemical and stream sediment survey of the National Uranium Resource Evaluation program, the Rocky Mountain states of New Mexico, Colorado, Wyoming, and Montana and the state of Alaska, October-December 1975, GJBX-38(76), US ERDA, Grand Junction, $\mathrm{CO}, 86 \mathrm{p}$.

5. Sharp, R. R., Jr., Morris, W. A., and Aamodt, P. L., 1976, Hydrogeochemical and stream sediment survey of the National Uranium Resource Evaluation program, the Rocky Mountain states of New Mexico, Colorado, Wyoming, and Montana and the state of Alaska, January-March 1976, GJBX-39(76), US ERDA, Grand Junction, CO, 56 p.

6. Morris, W. A. and Aamodt, P. L., 1976, Hydrogeochemical and stream sediment reconnaissance of the National Uranium Resource Evaluation program, the Rocky Mountain states of New Mexico, Colorado, Wyoming, and Montana and the state of Alaska, April-June 1976, GJBX-65(76), US ERDA, Grand Junction, CO, 25 p.

7. Morris, W. A., 1977, Hydrogeochemical and stream sediment reconnaissance of the National Uranium Resource Evaluation program, the Rocky Mountain states of New Mexico, Colorado, Wyoming, and Montana and the state of Alaska, July-September 1976, GJBX-12(77), US ERDA, Grand Junction, CO, $22 \mathrm{p}$.

8. Aamodt, P. L., Hansel, J. M., Jr., Minor, M. M., and Beckman, R. J., 1977, Hydrogeochemical and stream sedilient reconnaissance of ine National Uranium Resource Evaluation program, the Rocky Mountain states of New Mexico, Colorado, Hyoming, and Montana and the state of Alaska, October-December 1976, GJBX-20(77), US ERDA, Grand Junction, CO, 27 p.

9. Hues, A. D., Henicksman, A. L., Ashley, W. H., and Romero, D., 1977, The fluorometric determination of uranium in natural waters at the Los Alamos Scientific Laboratory, Los Alamos, NM, GJBX-24-77, US ERDA, Grand Junction, $\mathrm{CO}, 11 \mathrm{p}$. 
10. Fenneman, N. M., 1931, Physiography of the western United States, McGraw-Hill Book Co., New York, NY, pp. 183-224.

11. Montana State Engineers Office, 1965, Water resources survey, Flathead and Lincoln Counties, Montana, Parts I and II, Helena.

12. US Department of Commerce, 1970-1976, Climatological Data, Montana, Annual Summaries 1970-1976, NOAA, Environmental Data Service, v. 73-79, no. 13 (in each case), Ashville, NC.

13. US Geological Survey and Montana Bureau of Mines and Geology, 1963, Mineral and water resources of Montana, US Govt. Print. Off., Washington, DC, 166 p.

14. Johns, W. M., 1970, Geology and mineral deposits of Lincoln and Flathead Counties, Montana, Bull. 79, Montana Bureau of Mines and Geology, Butte, $182 \mathrm{p}$.

15. Harrison, J. E., 1Si2, Precambrian Belt basin of northwestern United States: It's geometry, sedimentation, and copper occurrences, Geil. Soc. Am. Bull., v. 83, pp. 1215-1240.

16. Harrison, J. E. and Grimes, D. J., 1970, Mineralogy and geochemistry of some Belt rocks, Montana and Idaho, USGS Bull. 1312-0, Washington, DC, $49 \mathrm{p}$.

17. Gibson, R., 1934, Gold-quartz veins south of Libby, Montana, USGS Circ. 7. Washington, DC, $25 \mathrm{p}$.

18. Gibson, R., 1948, Geology and ore deposits of the Libby quadrangle, Montana, USGS Bull. 956, Washington, DC, $131 \mathrm{p}$.

19. Gibson, R., Campbell, I., and Jenks, W. F., 1938, Quartz monzonite and related rocks of the Libby quadrangle, Montana, and the effects on them of deuteric processes, Am. Jour. Sci., v. 35, pp. 345-369.

20. Gibson, R. and Jenks, W. F., 1938, Amphibolization of sills and dikes in the Libby quadrangle, Montana, Am. Mineralogist, v. 23, pp. 302-313.

21. Gibson, R., Jenks, W. F., and Campbell, I., 1941, Stratigraphy of the Belt Se:'ies in Libby and Trout Creek quadrangles, northwestern Montana and northern Idaho, Geol. Soc. Am. Bull., v. 52, pp. 363-379.

22. Kleinkopf, M. D., Harrison, J. E., and Zartman, R. E., 1972, Aeromagnetic and geologic map of part of northwestern Montana and northern Idaho, USGS Geophysical Investigations Map GP-830, Washington, DC.

23. US Geological Survey, 1969, Aeromagnetic map of the Libby and Mt. Pend Oreille quadrangles, Lincoln and Sanders Counties, Montana, and Bonner County, Idaho, Geophysical Investigations Map GP-682, Washington, DC.

24. US Geological Survey, 1969, Aeromagnetic map of the Thompson Lakes quadrangle, Lincoln, Sanders, and Flathead Counties, Montana, Geophysical Investigations Map GP-683, Washington, DC. 
25. US Geological Survey, 1969, Aeromagnetic map of the McGregor Lake-Tally Lake area, Flathead and Lincoln Counties, Montana, Geophysical

Investigations Map GP-684, Washington, DC.

26. Johns, W. M., Smith, A. G., Barnes, W. C., Gilmour, E. H., and Page, W. D., 1963, Geologic investigations in the Kootenai-Flathead area, northwest Montana, No. 5, Western Flathead County and part of Lincoln Jounty, Montana Bureau of Mines and Geology Bull. 36, 68 p.

27. White, W. H., 1959, Cordilleran tectonics in British Columbia, Bull. Am. Assn. Petr. Geol., v. 43, pp. 60-100.

28. Hobbs, S. W., Griggs, A. B., Wallace, R. E., and Campbell, A. B., 1965, Geology of the Cour d' Alene district, Shoshone County, Idaho, USGS Prof. Paper 478, Washington, DC, 139 p.

29. Bentley, C. B. and Mowat, G. D., 1967, Reported occurrences of selected minera?s in Montana, USGS Mineral Investigations Resource Map MR-50 Washington, DC.

30. Vhay, J.S., 1951, Reconnaissance examination for uranium at six mines and properties in Idaho and Montana, USGS/AEC, TEM-30A, Tech. Info. Ser., Oak Ridge, TN, $21 \mathrm{p}$.

31. Sharp, R. R., Jr., 1977, The LASL approach to uranium geochemical reconnaissance, paper (LA-UR-77-1122) presented at the March 1977 Symposium on Hydrogeochemical and Stream Sediment Reconnaissance for Uranium in the United States, sponsored by the ERDA GJO and Bendix Field Eng. Corp., Grand Junction, CO, 21 p.

32. Grimbert, A. and Loriod, R., 1968, Geochemical prospecting for uranium, AEC-tr-7579 (trans. from French), US AEC, Tech. Info. Center, Springfield, VA, $38 \mathrm{p}$.

33. Doi, K., Hirono, S., and Sakamaki, Y., 1975, Uranium mineralization by ground water in sedimentary rocks, Japan, Econ. Geol., v. 70, pp. 628-646.

34. Fauth, H., 1973, Hydrogeochemical reconnaissance prospecting (with discussion), Uranium Exploration Methods, IAEA, 1972, Vienna, pp. 209-218.

35. Brown, B. W., 1971, Geochemistry and ore exploration, Geochemical Exploration, Spec. Vol. 11, Canadian Inst. Min. Met., pp. 113-115.

36. Fix, P. F., 1956, Geochemical prospecting for uranium by sampling ground and surface waters, Proc. UN Int. Conf. on Atomic Energy, 1955, v. 6, pp. 788-79\%.

37. Germanov, A. E., Batulin, S. G., Volkov, G. A., Lisitsin, A. K., and Serebrennikov, V. S., 1958, Some regularities of uranium distribution in underground water, Proc. 2nd UN Int. Conf. on Atomic Energy, Geneva, v. 2, pp. 161-177. 
38. Dyck, W.. 1975, Geochemistry applied to uranium exploration, Geol. Surv. Canada Paper 75-26, Info. Canada, Ottawa, pp. 33-47.

39. Ostle, D. and Ball, T. K., 1973, Some aspects of geochemical surveys for uranium (with discussion), Uranium Exploration Methods, IAEA, 1972, Vienna, pp. 171-187.

40. Ostle, D., 1954, Geochenical prospecting for uranium, Min. Mag., v. 9, pp. 201-208.

41. Scott, R. C. and Barker, F. B., 1958, Radium and uranium in ground water of the United States, 2nd UN Int. Conf. on Atomic Energy, 1958, v. 2, pp. 153-157,

42. Dall'Aglio, M., 1971, A study of the circulation of uranium in the supergene environment in the Italian Alpine Range, Geochem. et Cosmochim. Acta, v. 35, pp. 47-59.

43. Illsley, C. T., Bills, C. W., and Pollock, J. W., 1958, Some geochemical methods of uranium exploration, Proc. 2nd UN Int. Conf. on Atomic Energy, Geneva, v. 2, pp. 126-130.

44. MacDonald. J. A., 1969, An orientation study of the uranium distribution in lake waters, Beaverlodge District, Saskatchewan, Colorado School of Mines Quarterly, v. 64, pp. 357-376.

45. Whitehead, N. E. and Brooks, R. R., 1969, A comparative evaluation of scintillometric, geochemical, and biogeochemical methods of pruspecting for uranium, Econ. Geol., v. 64, pp. 50-56.

46. Boyle, R. W., 1969, Uranium, subsection in: Elemental associations in mineral deposits and indicator elements of interest in geochemical prospecting, Geol. Surv. Canada Paper 68-58, Queen's Printer, Octawa, pp. 21-23.

47. US Atomic Energy Commission and Geological Survey, 1956, Techniques for prospecting for uranium and thorium, Proc. UN Int. Conf. on Atomic Energy, 1955, v. 6, pp. 752-755.

48. Cameron, E. M. and Allen, R. J., 1973, Distribution of uranium in the crust of the northwestern Canadian shield as shown by lake-sediment analysis, Jour. Geochem. Expl., no. 2, pp. 237-250.

49. Boyle, R. W., Hornbrook, E. H. W., Allen, R. J., Dyke, W., and Smith, A. Y., 1971, Hydrogeochemical methods--application in the Canadian Shield, Geochemical Exploration in the Canadian Shield, State of the Art--Water, Canadian Min. Met. Bul1., v. 64, pp. 60-71.

50. King, J., Tauchid, M., Frey, D., and Basset, M., 1976, Exploration for uranium in southwestern Anatolia--a case study, Paper SM/208/06, presented at Int. Symp. Expl. of Uranium Ore Deposits, IAEA, Vienna, 22 p. 
51. Dyck, W., Dass, A. S., Durham, C. C., Hobbs, J. D., Pelchat, J. C., and Galbraith, J.H., 1971, Comparison of regional geochemical uranium exploration methods in the Beaverlodge area, Saskatchewan, Geochemical Exploration, Spec. Vol. 11, Canadian Inst. Min. Met., pp. 132-150.

52. Murakami, Y., Fujiwara, S., Sato, M., and Ohashi, S., 1958, Chemical prospecting of uranium deposits in Japan, Proc. 2nd UN Int. Conf. on Atomic Energy, Geneva, v. 2, pp. 131-139.

53. Chamberlain, J.A., 1964, Hydrogeochemistry of uranium in the Bancroft-Haliburton Region, Ontario, Geol. Surv. Canada Bull. 118, Queen's Printer, Ottawa, 19 p.

54. Wodzicki, A., 1959, Geochemical prospecting for uranium in the lower Buller Gorge, New Zealand, NZ Jour. Geol. Geophys., v. 2, pp. 602-612.

55. Peacock, J. D., 1961, Uranium in British surface and underground waters, Nature, v. 191, pp. 1189-1190.

56. Lopatkina, A. P., 1964, Characteristics of migration of uranium in the natural waters of humid regions and their use in the determination of the geochemical background for uranium, Geochem. Int., no. 4, pp. 788-795.

57. Saukoff, A. A., 1956, Radiohydrogeological method in prospecting for uranium deposits, Proc. UN Int. Conf. on Atomic Energy, 1955, Geneva, v. 6, pp. 756-759.

58. Lovering, T. S., Lakin, H. W., Ward, F. M., and Canney, F. C., 1956, The use of geochemical techniques and methods in prospecting for uranium, USGS Prof. Paper 300, 1955, Washington, DC, pp. 659-665.

59. Boberg, W. W. and Runnells, D. D., 1971, Reconnaissance study of uranium in the South Platte River, Colorado, Econ. Geol., v. 66, pp. 435-450.

60. Olsen, C. E., 1977, Uranium hydrogeochemical and stream sediment pilot survey of the Estancia Valley--Bernalillo, Santa Fe, San Miguel, and Torrance Counties, New Mexico, GJBX-21(77), US ERDA, Grand Junction, CO, 32 p. and appendixes.

61. Wainerdi, R. E. and Uken, E. A., 1971, Modern methods of geochemical analysis, Plenum Press, New York, NY, 397 p. 


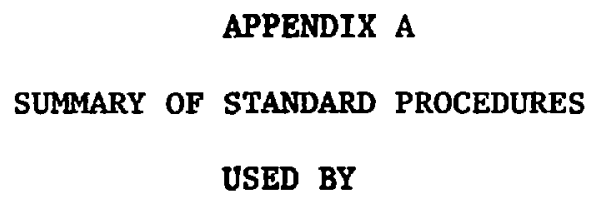

THE LOS ALAMOS SCIENTIFIC LABORATORY (LASL)

IN THE

US ENERGY RESEARCH AND DEVELCPMENT ADMINISTRATION (ERDA)

NATIONAL URANIUM RESOURCE EVALUATION (NURE)

HYDROGEOCHEMICAL AND STREAM SEDIMENT RECONNAISSANCE (HSSR)

(PAGES A-1 THROUGH A-4) 


\author{
SUMMARY OF STANDARD PROCEDURES \\ USED BY \\ THE LOS ALAMOS SCIENTIFIC LABORATORY (LASL) \\ IN THE \\ US ENERGY RESEARCH ARD DEVELOPMENT ADMINISTRATION (ERDA) \\ NATIONAL URANIUN RESOURCE EVALUATION (NURE) \\ HYDROGEOCHEMICAL AND STREAM SEDIMENT RECONNAISSANCE (HSSR)
}

\title{
I. FIELD PROCEDURES
}

Water Sampling

Hater samples are taken directly from the source wherever possible, filtered through a 0.45 -micron membrane filter into one each, prewashed and sealed, 41-ml reactor "rabbit" and 25-ml vial (both polyethylene), and both are then acldified to a $\mathrm{pH} \leq 1$ with $8 \mathrm{~N}$, reagen srade, HNO ${ }^{\text {. All }}$ sample containers are doubly labeled with preprint:, adhesive labels carrying the same sample location number preprinted on the field data form. Springs are sampled as near to their point of eberyence as possible; stream waters are taken from fast-flowing current ares from the bank; ponds (including small lakes and reservoirs) are sampled (rom just below the surface, away from the bank; and well waters are taken near the wellhead if the well is pumping or from a holding tank if not.

Sediment Sampling (Wet or Dry)

Enough fine-grained, organic-rich, water-transported sediment to yield a composite sample of $25 \mathrm{~g}$ after processing (as indicated below) is taken from beneath the water level (where water exists) at three closely atjacent spots at each location. This is done with a polyethylene scoop, after the water sample (if any) is taken. The sediment is put into a new, clean, and originally sealed, rip-top polyethylene bag and properly double-labeled for delivery (with the field data form) to the contractor's drying facility. After drying at $\leq 100^{\circ} \mathrm{C}$, each sample is sieved through stainless steel sieves to -100 mesh. The -100 mesh fraction is put into a prewashed, 25-ml polyethylene vial, appropriately double-labeled (using labels from the data form), and sealed for shipment to the LASL.

\section{Field Measurements}

The air temperature, taken in the shade at the time of sampling, is recorded to the nearest whole degree centigrade. The water temperature is measured in the source water and recorded to the nearest one-half degree centigrade. All temperature measurements are made with quality, precalibrated thermometers. The pH of the source water is measured with a calibrated, portable $\mathrm{pH}$ meter or multi-range $\mathrm{pH}$ paper, and recorded to the nearest one-tenth of a pH unit. The specific conductance ( $\mu \mathrm{mho} / \mathrm{cm})$ of the source water is measured with a calibrated, temperature compensated $\left(25^{\circ} \mathrm{C}\right)$ portable meter after the attached sample cup has first been rinsed three times in the source water. The scintillometer readings, taken on a flat, dry spot within a few meters of the sample location, are measured with a portable scintilloweter. Two readings are recorded, the first with a radiation shield in place (blocking out ground radiation), and the second with the shield removed. The readings (in counts/s) are converted by computer to give the equivalent uranium (eU) value set forth in the data listing. 


\section{Field Observations}

These represent the best subjective judgment of the field sampler on location, and include very general descriptions of the local bedrock, sediment, water, vegetation, terrain, weather, possible contaminants, and water well configuration, if applicable.

\section{Sample Location Verification}

Each contractor is supplied field maps with the desired sample types and locations symbolically premarked at the LASL. The maps are normaliy USGS Quadrangles (either $7.5^{\prime}$ or $1^{\prime}$ ), but where not available, Forest Service, State Highway, or other reasonably detailed maps are provided. As each location is sampled, a unique sample location number, preprinted on transparent adhesive labels provided with the identically numbered field data forms, is pasted over the precisely marked site on the field map. The latitude and longitude of each location is computed by the sampling contractor. Every location is later checked (and corrected if necessary) at the LASL by overlaying computer produced location plots on the fleld maps used. The latitudes and/or longltudes are corrected if the overlay locations are displaced by more than $300 \mathrm{~m}$ from the locations marked on the fleld maps. When a desired location cannot be sampled as specified, an alternate sample type or location as near as possible to the original one is picked, and the new sample type and/or location is/are marked on the field map and properly labeled as above.

\section{ANALYTICAL PROCEDURES}

Hater Samples Analyzed for Uranium By Fluorometry

In a controlled laboratory environment, a NaF (98\%)-LiF (2\%) flux pellet is prepared and placed on a platinum dish. The $25-\mathrm{m}$ ? water vial is vigorously shaken and a $0.25-\mathrm{ml}$ aliquot of water is withdrawn and dropped onto a flux pellet, then evaporated under a heat lamp. The sample flux is then heated until fused. After it cools, it is excited with ultra-violet radiation in the fluorometer, and the measured fluorescence is read, recorded, and put through a computer routine using standards and blanks run at the same time to obtain the uranium concentration. Water samples which have uranium concentrations in excess of $10 \mathrm{ppb}$ (the upper limit of detection of the fluorometry system without recalibration) are reanalyzed using the delayed neutron counting technique described below.

Water Samples Analyzed for Uranium by Delayed Neutron Counting (DNC)

Only waters with $>10$ ppb uranium are assayed using DNC. Samples taken in the 4l-ml rabbits are thoroughly cleaned (exterior) before analysis. Samples received in 25-ml vials (used exclusively in some of the early work) are transferred to clean, labeled, 4l-ml rabbits before being analyzed. Each water sample is weighed, and its weight (less that of the rabbit) and location number are recorded. The rabbits are then loaded into a 25-sample transfer clip. The reactor pneumatic transfer system and background radiation levels are checked, and the system is calibrated using four standards. The transfer clip is installed on the pneumatic feed line, and the count control is set (typically, a 60-s irradiation, a 3n-a delay, and a 60-s count is used, but 
this can be changed to accormodate abnormally high or low uranium concentrations). The samples are cycled through the system and the uranium concentration is automatically measured, computed in ppb, and entered into the data base.

\section{Uranium Analysis of Sediment Samples}

All sediment samples are analyzed for total uranium by DNC. A split of each sample (dried and sieved as described) is transferred to a clean 4-ml rabbit, weighed (less the tare), and recorded along with the appropriate location number. Tho readied rabbits are loaded into a 50-sample transfer clip. The reactor prieumatic transfer system and background radiation levels are checked, and the system is calibrated as above. The transfer clip is installed and the count control is set (typically, a 20-s irradiation, a 10-s delay, and a 20-s count is used). The samples are cycled through the system and the uranium concentration is automatically measured, computed in ppm, and entered into the data base. 
APPENDIX B

HISTOGRAMS OF URANIUM CONCENTRATIONS

IN WATER AND SEDIMENT SAMPLES FROM LINCOLN AND FLATHEAD COUNTIES, NORTHWEST MONTANA

\author{
APPENDIX B-I \\ RAW DATA AND LOG DATA HISTOGRAMS \\ FOR URANIUM IN WATER \\ (PAGES B-2 THROUGH B-6)
}

\begin{abstract}
ALL CONCENTRATIONS SHOWN ARE TOTAL URANIUM IN
PARTS PER BILLION (PPB) FOR FILTERED AND ACIDIFIED SAMPLES

ANALYZED BY FLUOROMETRY IF $\leq 10 \mathrm{PPB}$ OR

DELAYED NEUTRON COUNTING IF $>10 \mathrm{PPB}$
\end{abstract}



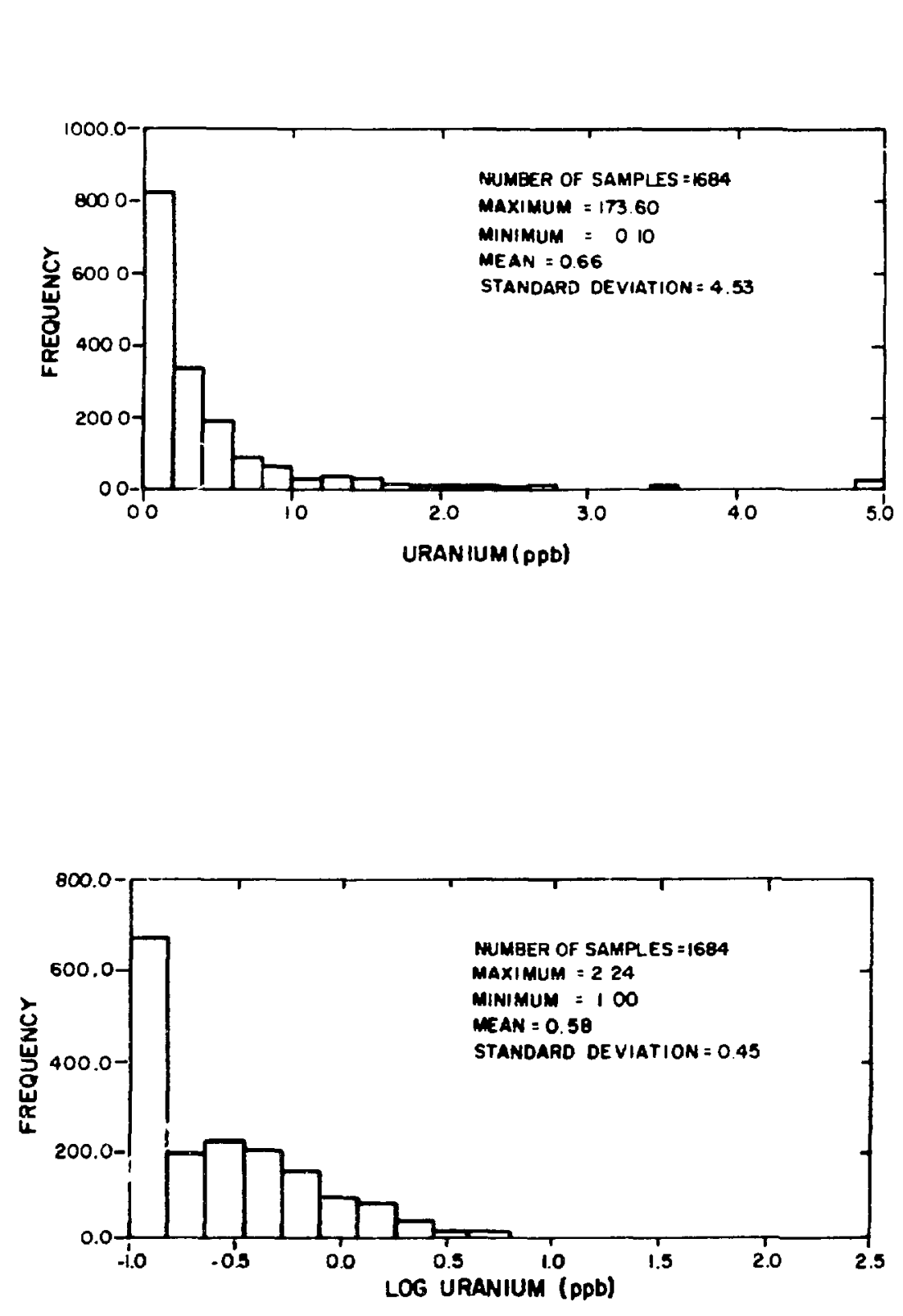

\begin{tabular}{rrr}
\multicolumn{2}{c}{ Range } & Frequency \\
\cline { 2 - 2 }-1.00 & -0.82 & 671 \\
-0.82 & -0.64 & 193 \\
-0.64 & -0.46 & 220 \\
-0.46 & -0.28 & 199 \\
-0.28 & -0.10 & 151 \\
-0.10 & 0.08 & 95 \\
0.08 & 0.26 & 80 \\
0.26 & 0.44 & 38 \\
0.44 & 0.62 & 13 \\
0.62 & 0.80 & 14 \\
0.80 & 0.98 & 1 \\
0.98 & 1.16 & 1 \\
1.16 & 1.34 & 3 \\
1.34 & 1.52 & 4 \\
1.52 & 1.70 & 0 \\
1.70 & 1.88 & 0 \\
1.88 & 2.06 & 0 \\
2.06 & 2.24 & 1
\end{tabular}




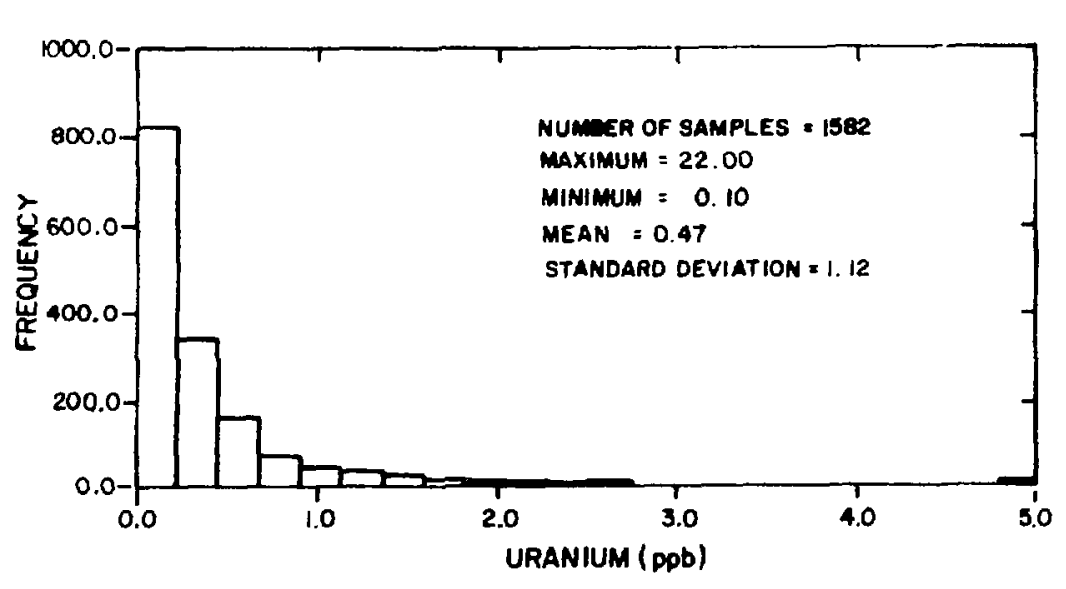

\begin{tabular}{rrr}
\multicolumn{2}{c}{ Rarge } & Frequency \\
\hline 0.0 & 0.2 & 824 \\
0.2 & 0.5 & 342 \\
0.5 & 0.7 & 166 \\
0.7 & 0.9 & 73 \\
0.9 & 1.1 & 46 \\
1.1 & 1.4 & 34 \\
1.4 & 1.6 & 26 \\
1.6 & 1.8 & 15 \\
1.8 & 2.1 & 9 \\
2.1 & 2.3 & 8 \\
2.8 & 2.5 & 6 \\
2.5 & 2.7 & 9 \\
2.7 & 3.0 & 3 \\
3.0 & 3.2 & 2 \\
3.2 & 3.4 & 1 \\
3.4 & 3.7 & 3 \\
3.7 & 3.9 & 0 \\
3.9 & 4.1 & 1 \\
4.1 & 4.3 & 0 \\
4.3 & 4.6 & 1 \\
4.6 & 4.8 & 3 \\
4.8 & 22.0 & 10 \\
& &
\end{tabular}

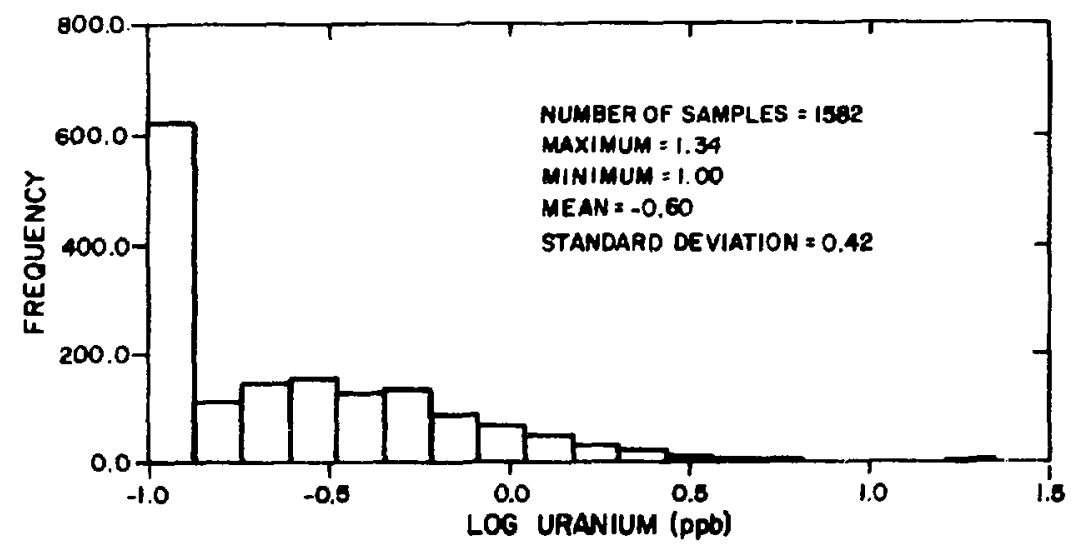

\begin{tabular}{ccc}
\multicolumn{2}{c}{ Range } & Frequency \\
\hline-1.0 & -0.87 & 619 \\
-0.87 & -0.74 & 113 \\
-0.74 & -0.61 & 145 \\
-0.61 & -0.48 & 151 \\
-0.48 & -0.35 & 126 \\
-0.35 & -0.22 & 132 \\
-0.22 & -0.09 & 88 \\
-0.09 & 0.04 & 69 \\
0.04 & 0.17 & 54 \\
0.17 & 0.30 & 34 \\
0.30 & 0.43 & 25 \\
0.43 & 0.56 & 11 \\
0.56 & 0.69 & 6 \\
0.69 & 0.82 & 5 \\
0.82 & 0.95 & 0 \\
0.95 & 1.08 & 0 \\
1.08 & 1.21 & 1 \\
1.21 & 1.34 & 3
\end{tabular}

URANIUM IN WATER FROM STREAMS ONLY 


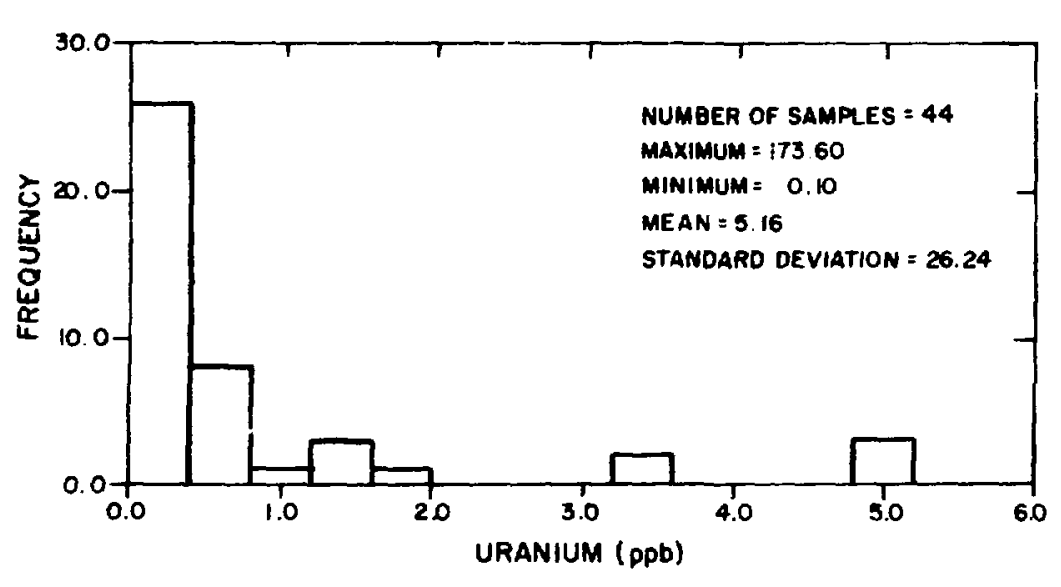

\begin{tabular}{rrr}
\multicolumn{2}{c}{ Range } & Fri wericy \\
\hline 0.0 & 0.4 & 26 \\
0.4 & 0.8 & 8 \\
0.8 & 1.2 & 1 \\
1.2 & 1.6 & 3 \\
1.6 & 2.0 & 1 \\
2.0 & 2.4 & 0 \\
2.4 & 2.8 & 0 \\
2.8 & 3.2 & 0 \\
3.2 & 3.6 & 2 \\
3.6 & 4.0 & 0 \\
4.0 & 4.4 & 0 \\
4.4 & 4.8 & 0 \\
4.8 & 173.6 & 3
\end{tabular}

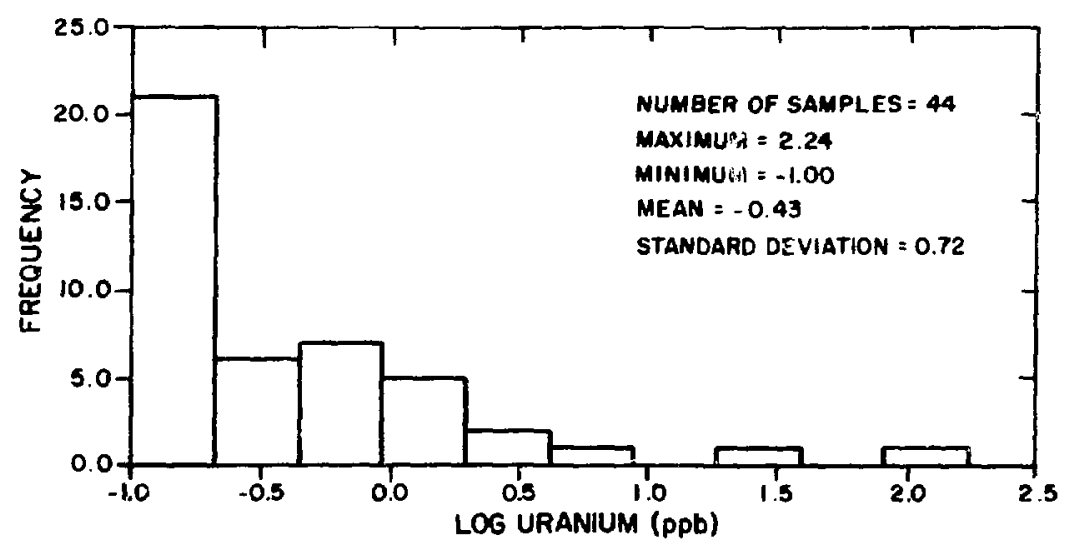

\begin{tabular}{rrr}
\multicolumn{2}{c}{ Range } & Frequency \\
\hline-1.00 & -0.68 & 21 \\
-0.68 & -0.35 & 6 \\
-0.35 & -0.03 & 7 \\
-0.03 & 0.30 & 5 \\
0.30 & 0.62 & 2 \\
0.62 & 0.94 & 1 \\
0.94 & 1.27 & 0 \\
1.27 & 1.59 & 1 \\
1.59 & 1.92 & 0 \\
1.92 & 2.24 & 1
\end{tabular}

URANIUM IN WATER FROM NATURAL PONDS ONLY 


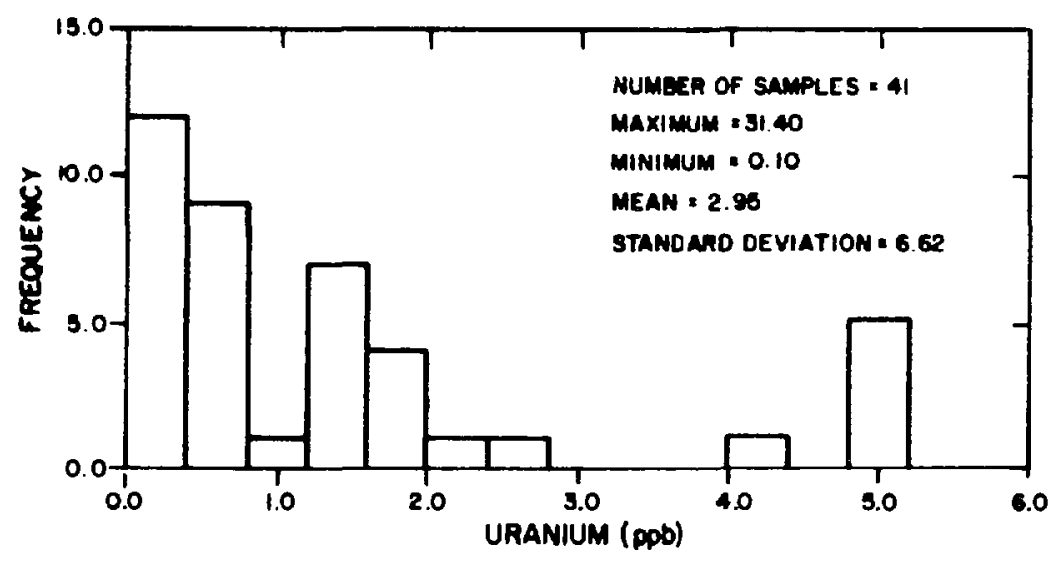

\begin{tabular}{rr}
\multicolumn{2}{c}{ Range } \\
\hline 0.0 & 0.4 \\
0.4 & 0.8 \\
6.8 & 1.2 \\
1.2 & 1.6 \\
1.6 & 2.0 \\
2.0 & 2.4 \\
2.4 & 2.8 \\
2.8 & 3.2 \\
3.2 & 3.6 \\
3.6 & 4.0 \\
4.0 & 4.4 \\
4.4 & 4.8 \\
4.8 & 31.4
\end{tabular}

Frequency

12
9
1
7
4
1
1
0
0
0
1
0
5

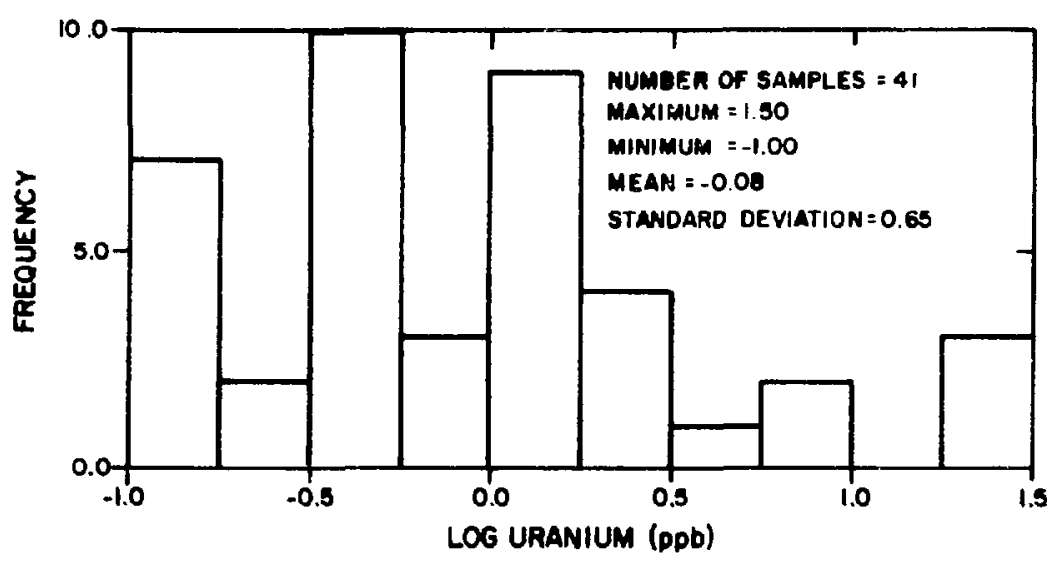

\begin{tabular}{rrr}
\multicolumn{2}{c}{ Range } & Frequency \\
\hline-1.00 & -0.75 & 7 \\
-0.75 & -0.50 & 2 \\
-0.50 & -0.25 & 10 \\
-0.25 & -0.00 & 3 \\
-0.00 & 0.25 & 9 \\
0.25 & 0.50 & 4 \\
0.50 & 0.75 & 1 \\
0.75 & 1.00 & 2 \\
1.00 & 1.25 & 0 \\
1.25 & 1.50 & 3
\end{tabular}

URANIUM IN WATER FROM SPRTNGS ONLY 


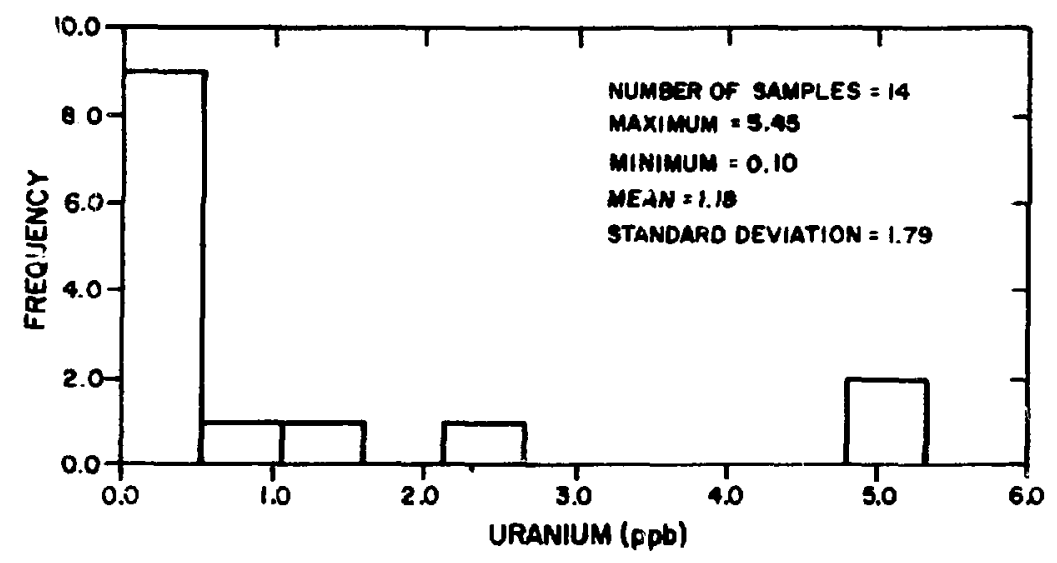

\begin{tabular}{lll}
\multicolumn{2}{c}{ Range } & Frequency \\
\hline 0.0 & 0.5 & 9 \\
0.5 & 1.1 & 1 \\
1.1 & 1.6 & 1 \\
1.6 & 2.1 & 0 \\
2.1 & 2.7 & 1 \\
2.7 & 3.2 & 0 \\
3.2 & 3.7 & 0 \\
3.7 & 4.3 & 0 \\
4.3 & 4.8 & 0 \\
4.8 & 5.4 & 2
\end{tabular}

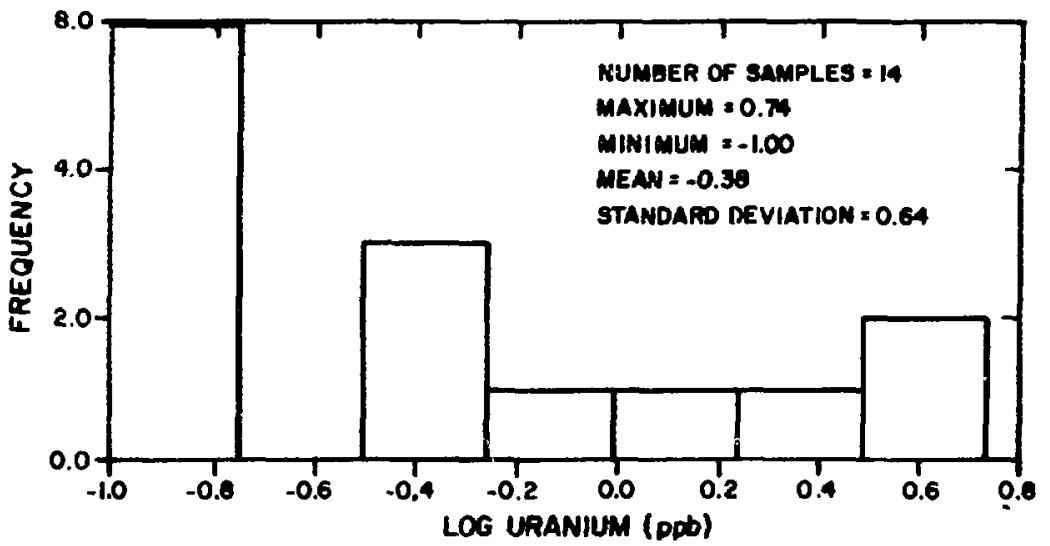

\begin{tabular}{rrr}
\multicolumn{2}{c}{ Range } & Frequency \\
\hline-1.00 & -0.75 & 6 \\
-0.75 & -0.50 & 0 \\
-0.50 & -0.26 & 3 \\
-0.26 & -0.01 & 1 \\
-0.01 & 0.24 & 1 \\
0.24 & 0.49 & 1 \\
0.49 & 0.74 & 2
\end{tabular}




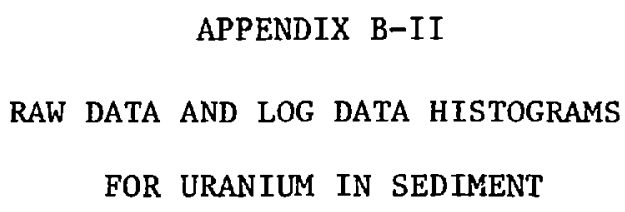

(PAGES B-8 THROUGH B-13)

\section{ALL CONCENTRATIONS SHOWN ARE TOTAL URANIUM IN \\ PARTS PER MILLION (PPM) FOR DRIED AND SIEVED (I00 MESH FRACTION) \\ SAMPLES ANALYZED BY DELAYED NEUTRON COUNTING}




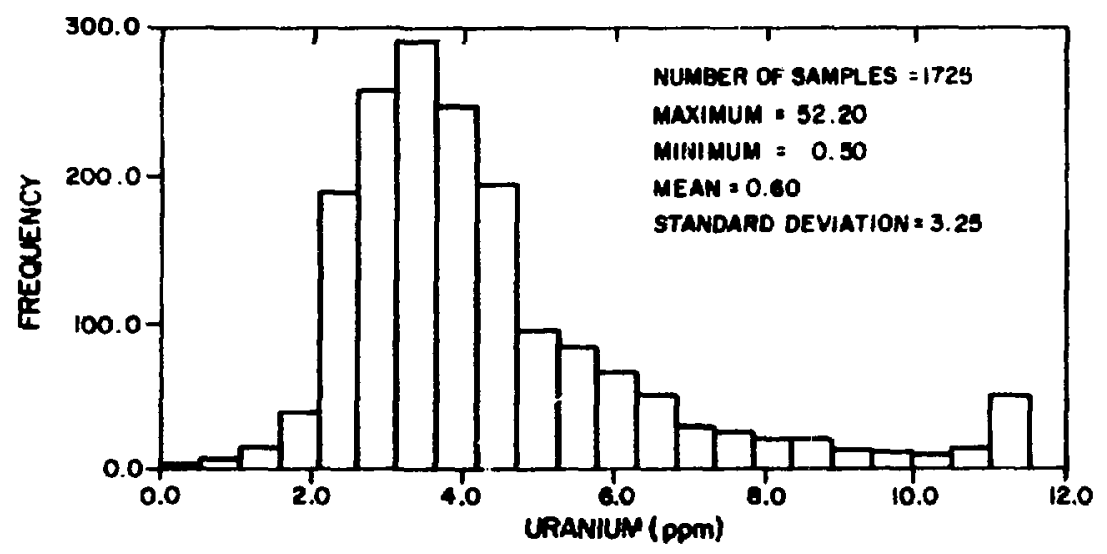

\begin{tabular}{rrr}
\multicolumn{2}{c}{ Range } & Frequency \\
\hline 0.0 & 0.5 & 1 \\
0.5 & 1.0 & 5 \\
1.0 & 1.6 & 15 \\
1.6 & 2.1 & 37 \\
2.1 & 2.6 & 189 \\
2.6 & 3.1 & 256 \\
3.1 & 3.7 & 291 \\
3.7 & 4.2 & 247 \\
4.2 & 4.7 & 196 \\
4.7 & 5.2 & 96 \\
5.2 & 5.8 & 84 \\
5.8 & 6.3 & 67 \\
6.3 & 6.8 & 51 \\
6.8 & 7.3 & 29 \\
7.3 & 7.9 & 26 \\
7.9 & 8.4 & 20 \\
8.4 & 8.9 & 20 \\
8.9 & 9.4 & 12 \\
9.4 & 10.0 & 11 \\
10.0 & 10.5 & 9 \\
10.5 & 11.0 & 13 \\
11.0 & 52.2 & 50 \\
& &
\end{tabular}

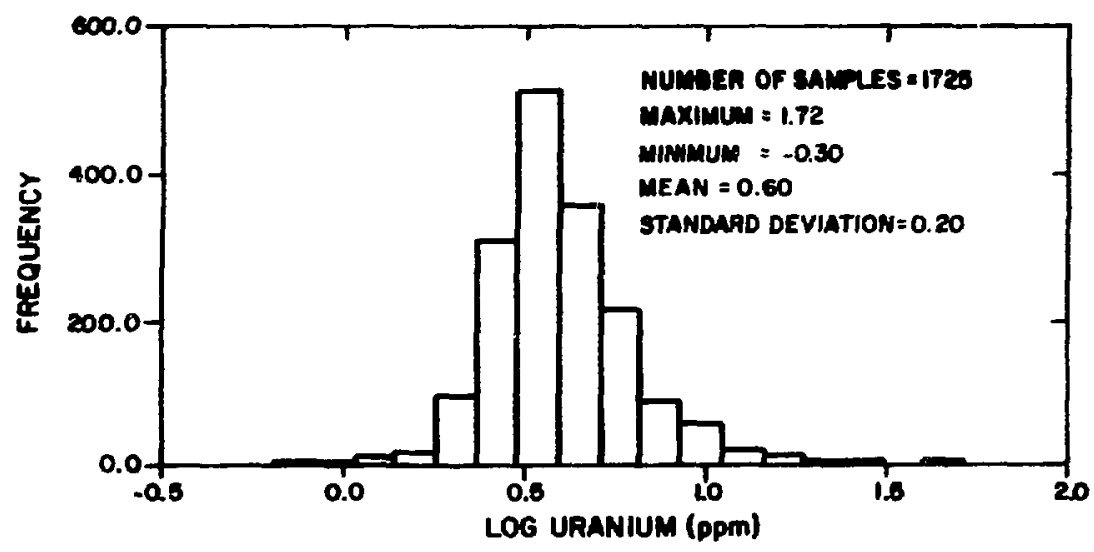

\begin{tabular}{rrr}
\multicolumn{2}{c}{ Range } & Frequency \\
\hline-0.30 & -0.19 & 1 \\
-0.19 & -0.08 & 2 \\
-0.08 & 0.04 & 3 \\
0.04 & 0.15 & 11 \\
0.15 & 0.26 & 19 \\
0.26 & 0.37 & 95 \\
0.37 & 0.48 & 311 \\
0.48 & 0.60 & 510 \\
0.60 & 0.71 & 357 \\
0.71 & 0.82 & 217 \\
0.82 & 0.93 & 89 \\
0.93 & 1.04 & 60 \\
1.04 & 1.16 & 22 \\
1.16 & 1.27 & 16 \\
1.27 & 1.38 & 4 \\
1.38 & 1.49 & 4 \\
1.49 & 1.61 & 1 \\
1.61 & 1.72 & 3
\end{tabular}




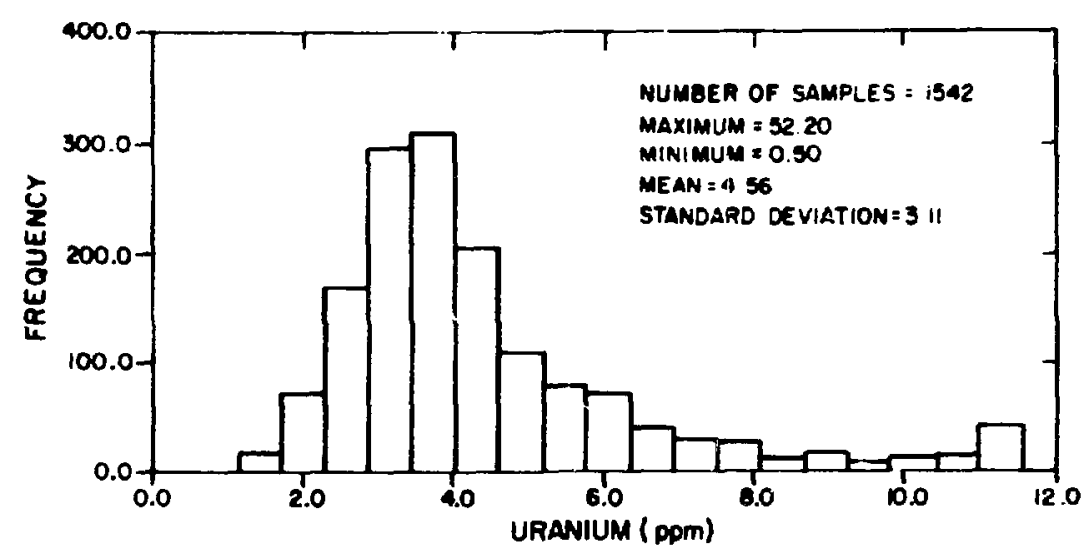

\begin{tabular}{rrr}
\multicolumn{2}{c}{ Range } & Frequency \\
\hline 0.0 & 0.6 & 1 \\
0.6 & 1.2 & 4 \\
1.2 & 1.7 & 20 \\
1.7 & 2.3 & 73 \\
2.3 & 2.9 & 171 \\
2.9 & 3.5 & 295 \\
3.5 & 4.1 & 310 \\
4.1 & 4.6 & 205 \\
4.6 & 5.2 & 110 \\
5.2 & 5.8 & 77 \\
5.8 & 6.4 & 72 \\
6.4 & 6.9 & 41 \\
6.9 & 7.5 & 30 \\
7.5 & 8.1 & 28 \\
8.1 & 8.6 & 12 \\
8.6 & 9.2 & 18 \\
9.2 & 9.8 & 10 \\
9.8 & 10.4 & 11 \\
10.4 & 11.0 & 13 \\
11.0 & 11.5 & 41 \\
& &
\end{tabular}

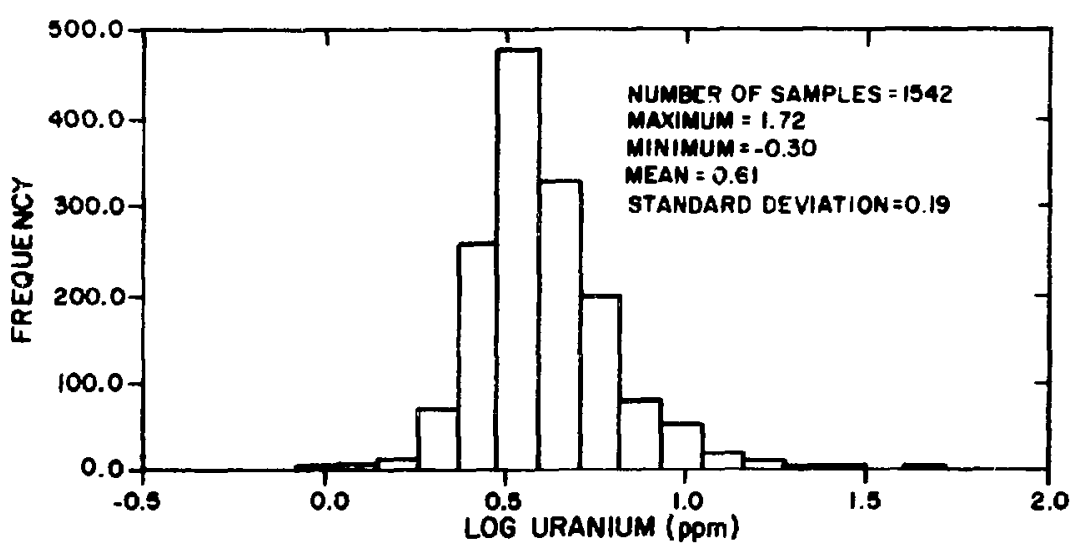

\begin{tabular}{rrr}
\multicolumn{2}{c}{ Range } & Frequency \\
\cline { 2 - 2 }-0.30 & -0.19 & 1 \\
-0.19 & -0.08 & 1 \\
-0.08 & 0.04 & 3 \\
0.04 & 0.15 & 8 \\
0.15 & 0.26 & 14 \\
0.26 & 0.37 & 71 \\
0.37 & 0.48 & 260 \\
0.48 & 0.60 & 478 \\
0.60 & 0.71 & 329 \\
0.71 & 0.82 & 201 \\
0.82 & 0.93 & 81 \\
0.93 & 1.04 & 54 \\
1.04 & 1.16 & 21 \\
1.16 & 1.27 & 12 \\
1.27 & 1.38 & 3 \\
1.38 & 1.49 & 2 \\
1.49 & 1.61 & 0 \\
1.61 & 1.72 & 3
\end{tabular}

URANIUM IN SEDIMENT FROM WET STREAMS ONLY 


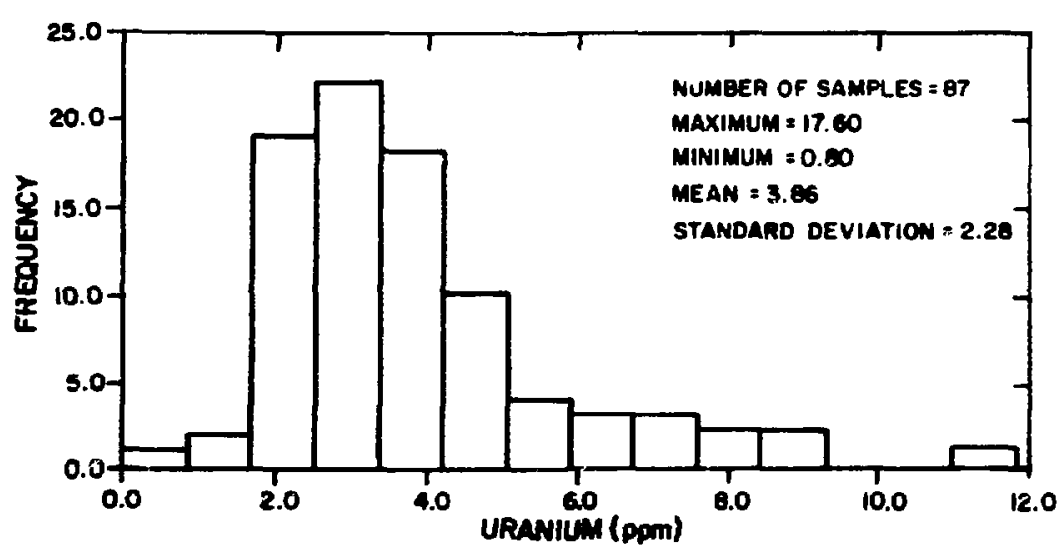

\begin{tabular}{rrr}
\multicolumn{2}{c}{ Range } & Frequency \\
\hline 0.0 & 0.8 & 1 \\
0.8 & 1.7 & 2 \\
1.7 & 2.5 & 19 \\
2.5 & 3.4 & 22 \\
3.4 & 4.2 & 18 \\
4.2 & 5.1 & 10 \\
5.1 & 5.9 & 4 \\
5.9 & 6.8 & 3 \\
6.8 & 7.6 & 3 \\
7.6 & 8.5 & 2 \\
8.5 & 9.3 & 2 \\
9.3 & 10.2 & 0 \\
10.2 & 11.0 & 0 \\
11.0 & 17.6 & 1 \\
& &
\end{tabular}

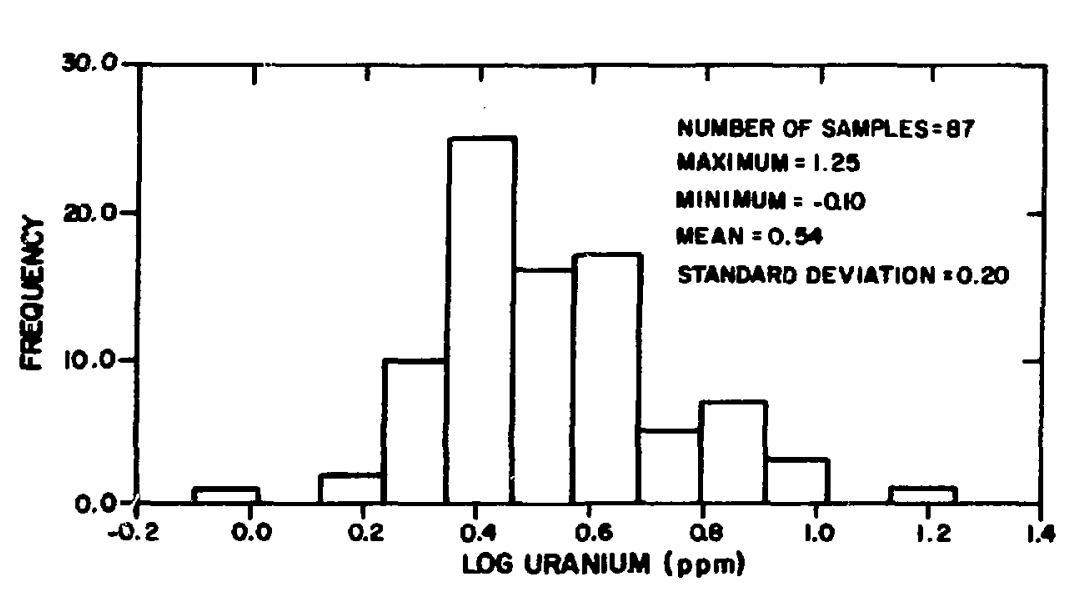

\begin{tabular}{rrr}
\multicolumn{2}{c}{ Range } & Frequency \\
\hline-0.10 & 0.01 & 1 \\
0.01 & 0.13 & 0 \\
0.13 & 0.24 & 2 \\
0.24 & 0.35 & 10 \\
0.35 & 0.46 & 25 \\
0.46 & 0.57 & 16 \\
0.57 & 0.69 & 17 \\
0.69 & 0.80 & 5 \\
0.80 & 0.91 & 7 \\
0.91 & 1.02 & 3 \\
1.02 & 1.13 & 0 \\
1.13 & 1.25 & 1
\end{tabular}

URANIUM IN SEDIMENT FROM DRY STREAMS ONLY 


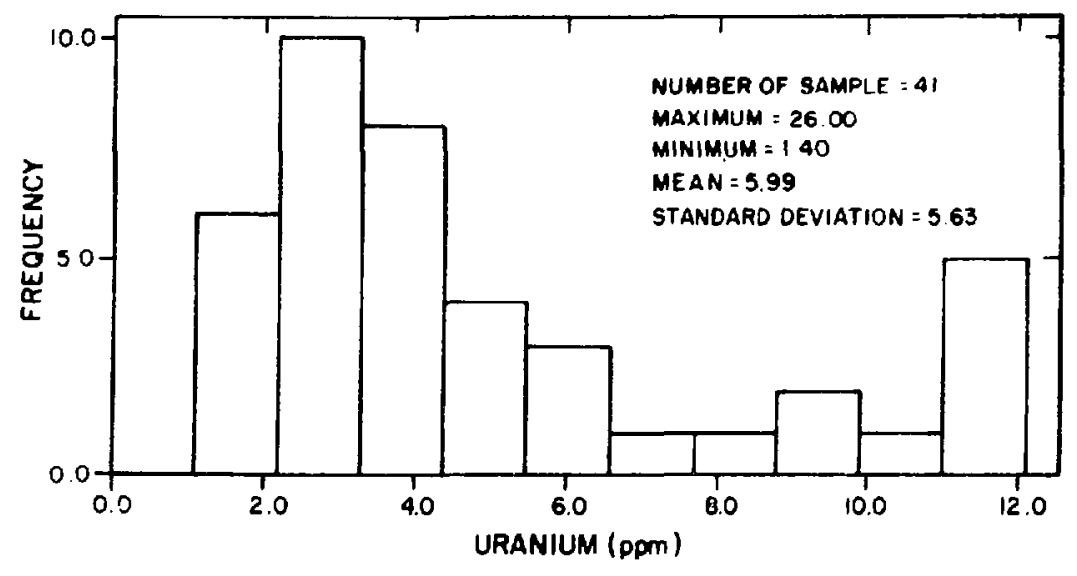

\begin{tabular}{lrr}
\multicolumn{2}{c}{ Range } & Prequenr \\
\hline 0.0 & 1.1 & \\
1.1 & 2.2 & 6 \\
2.2 & 3.3 & 10 \\
3.3 & 4.4 & 4 \\
4.4 & 5.5 & 4 \\
5.5 & 6.6 & 3 \\
6.6 & 7.7 & 1 \\
7.7 & 8.8 & 1 \\
8.8 & 9.9 & 2 \\
9.9 & 11.0 & 1 \\
11.0 & 12.1 & 5
\end{tabular}

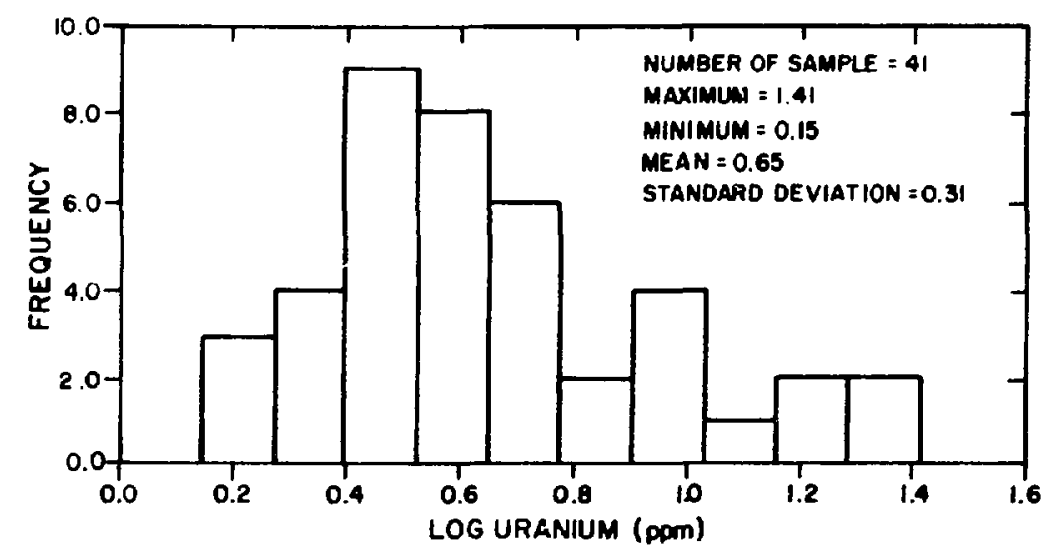

\begin{tabular}{ccc}
\multicolumn{2}{c}{ Range } & \multicolumn{2}{c}{ Frequency } \\
\hline 0.15 & 0.27 & 3 \\
0.27 & 0.40 & 4 \\
0.40 & 0.53 & 9 \\
0.53 & 0.65 & 8 \\
0.65 & 0.78 & 6 \\
0.78 & 0.91 & 2 \\
0.91 & 1.03 & 4 \\
1.03 & 1.16 & 1 \\
1.16 & 1.29 & 2 \\
1.29 & 1.41 & 2
\end{tabular}

URANIUM IN SEDIMENT FROM WET NATURAL PONDS ONIYY 


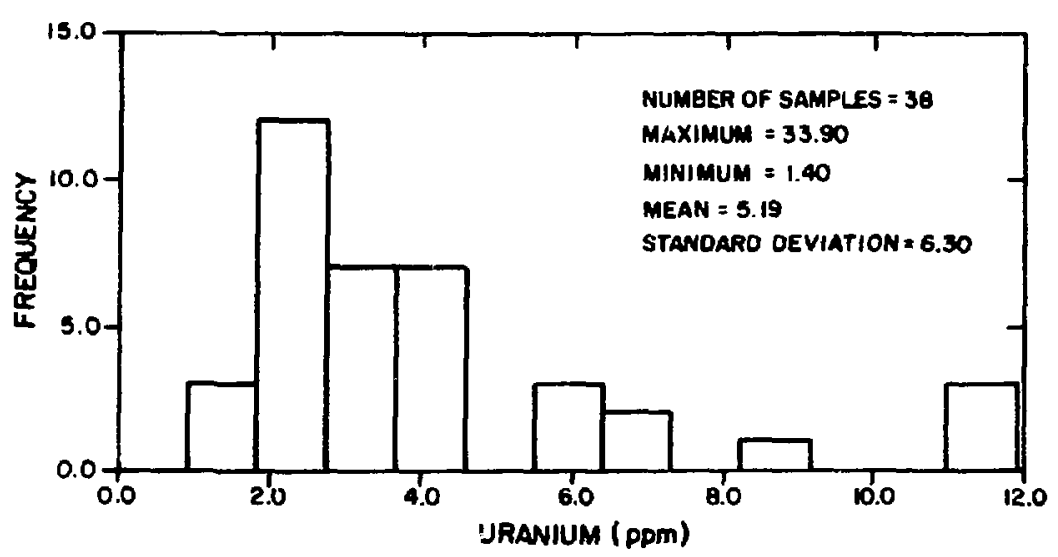

\begin{tabular}{rrr}
\multicolumn{2}{c}{ Range } & Frequency \\
\hline 0.0 & 0.9 & 0 \\
0.9 & 1.8 & 3 \\
1.8 & 2.7 & 12 \\
2.7 & 3.6 & 7 \\
3.6 & 4.5 & 7 \\
4.5 & 5.5 & 0 \\
5.5 & 6.4 & 3 \\
6.4 & 7.3 & 2 \\
7.3 & 8.2 & 0 \\
8.2 & 9.1 & 1 \\
9.1 & 10.0 & 0 \\
10.0 & 11.0 & 0 \\
11.0 & 33.9 & 3
\end{tabular}

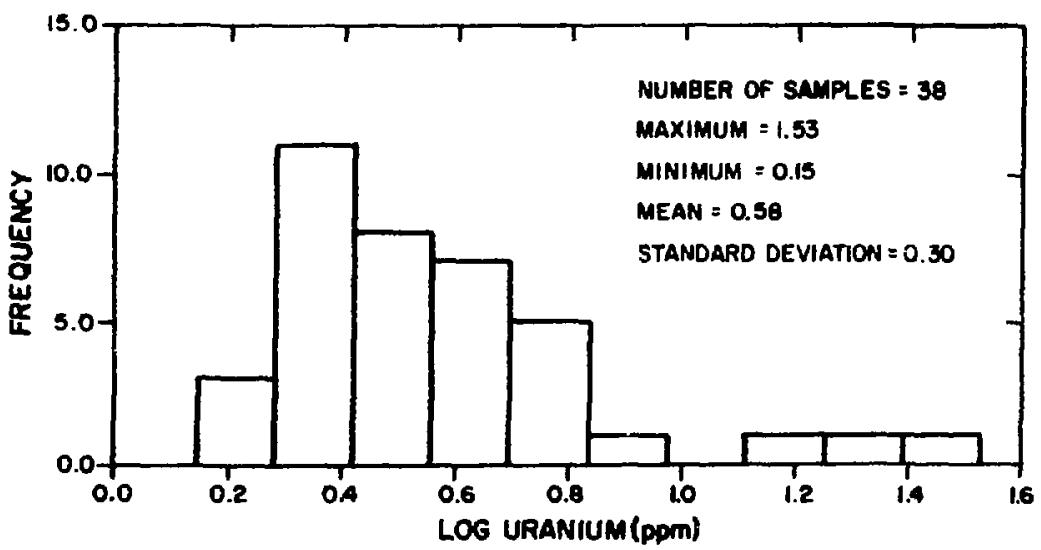

\begin{tabular}{lrr}
\multicolumn{2}{c}{ Range } & Frequency \\
\hline 0.15 & 0.28 & 3 \\
0.28 & 0.42 & 11 \\
0.42 & 0.56 & 8 \\
0.56 & 0.70 & 7 \\
0.70 & 0.84 & 5 \\
0.84 & 0.98 & 1 \\
0.98 & 1.11 & 0 \\
1.11 & 1.25 & 1 \\
1.25 & 1.39 & 1 \\
1.39 & 1.53 & 1
\end{tabular}




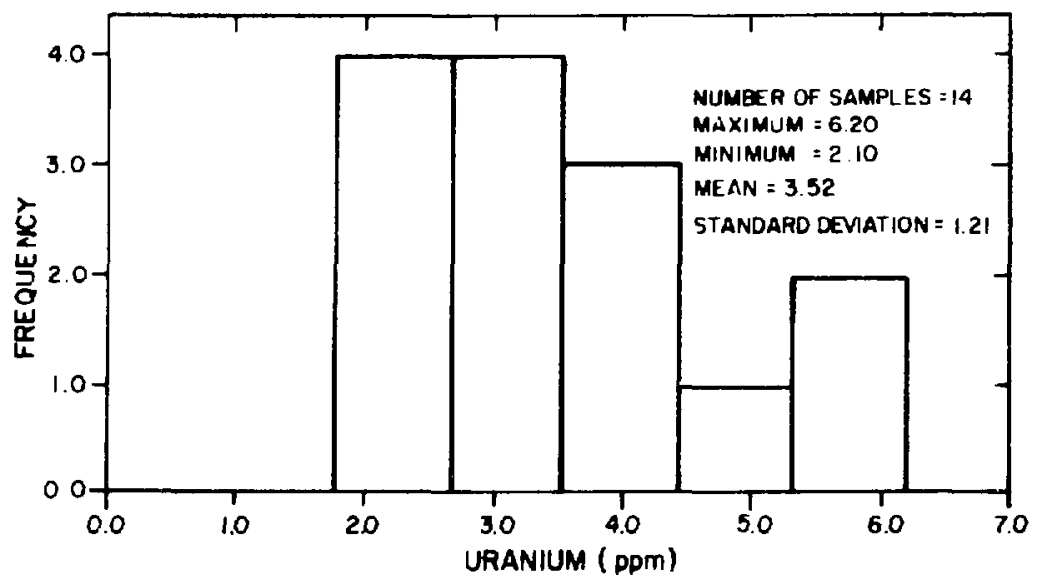

\begin{tabular}{ccc}
\multicolumn{2}{c}{ Range } & Frequency \\
\hline 0.0 & 0.9 & 0 \\
0.9 & 1.8 & 0 \\
1.8 & 2.7 & 4 \\
2.7 & 3.5 & 4 \\
3.5 & 4.4 & 3 \\
4.4 & 5.3 & 1 \\
5.3 & 6.2 & 2
\end{tabular}

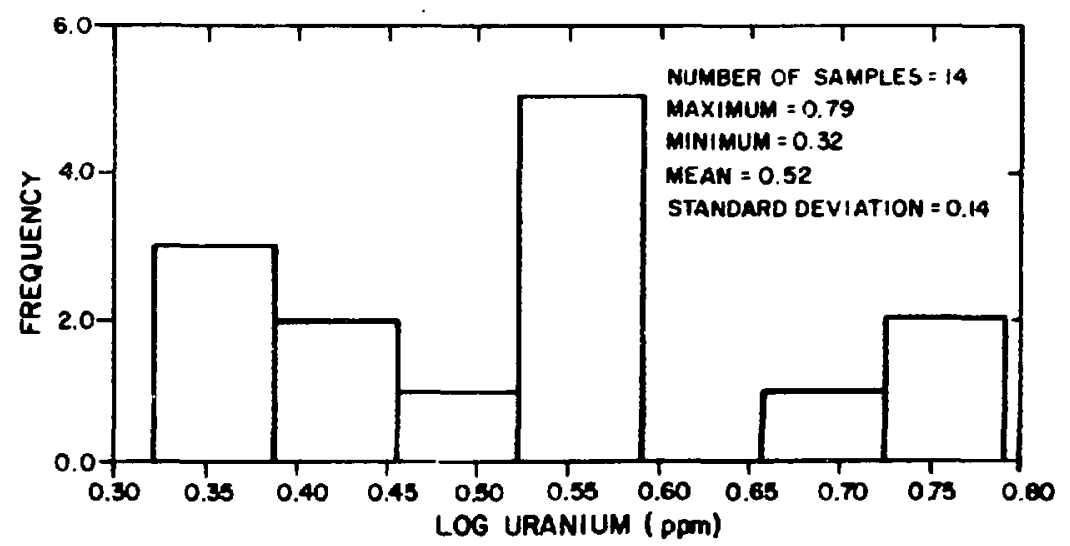

\begin{tabular}{lll}
\multicolumn{2}{c}{ Range } & Frequency \\
\hline 0.32 & 0.39 & 3 \\
0.39 & 0.46 & 2 \\
0.46 & 0.52 & 1 \\
0.52 & 0.59 & 5 \\
0.59 & 0.66 & 0 \\
0.66 & 0.73 & 1 \\
0.73 & 0.79 & 2
\end{tabular}

URANIUM IN SEDIMENT FROM WET ARTIFICIAL PONDS ONLY 


\author{
APPENDIX C \\ LISTINGS OF FIELD DATA AND URANIUM CONCENTRATIONS \\ FOR \\ FILTERED AND ACIDIFIED WATER SAMPLES \\ FROM \\ LINCOLN AND FLATHEAD COUNTIES, \\ NORTHWEST MONTANA \\ APPENDIX C-I \\ WATER SAMPLES ANÄYZED BY FLUOROMETRY \\ (PAGES C-2 THROUGH C-34)
}

(See Appendix E for codes to listings) 


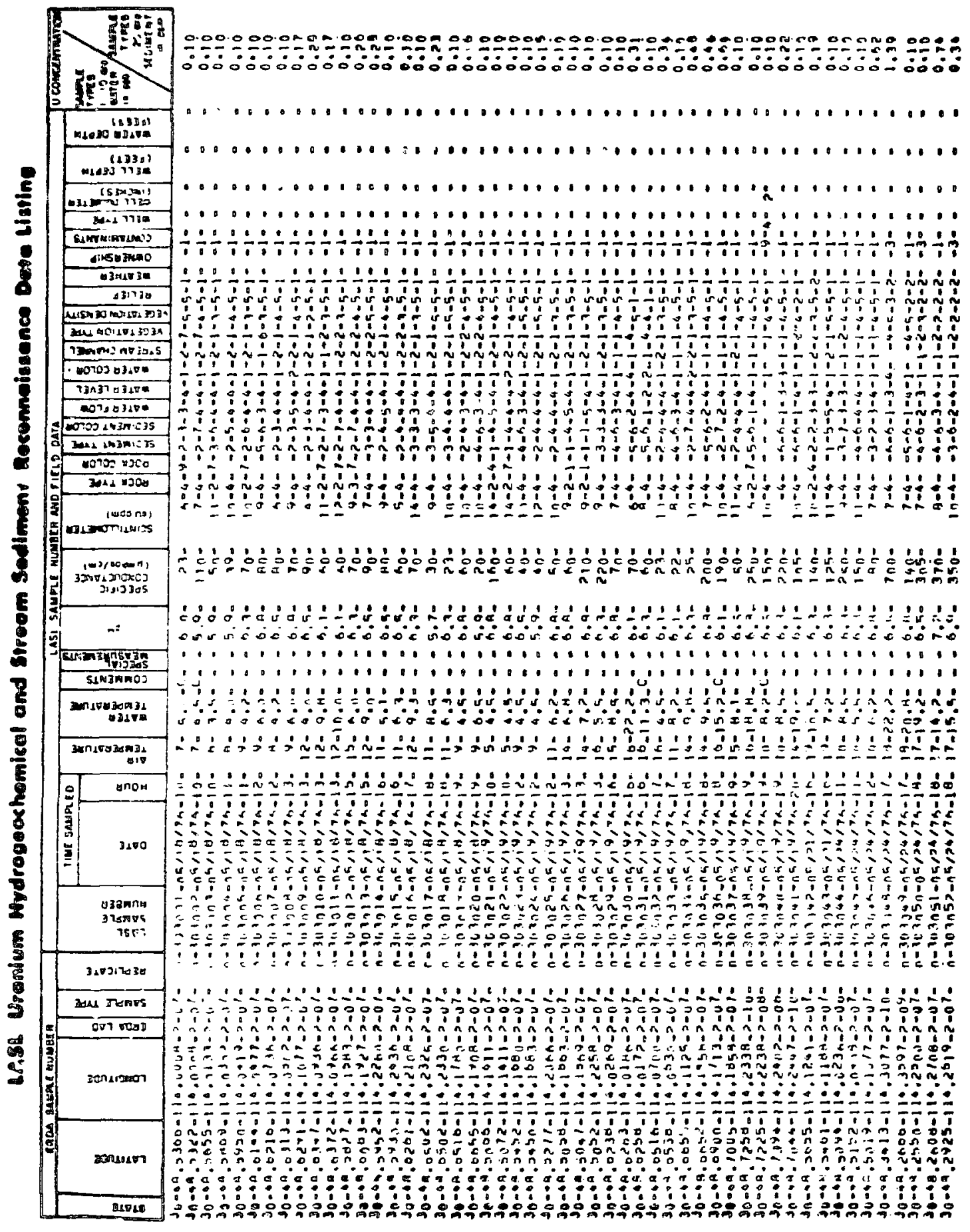


LAst Uronium Hydrogeoxhomica: and Streem Sodimeat Roconnoissonce Date Listing

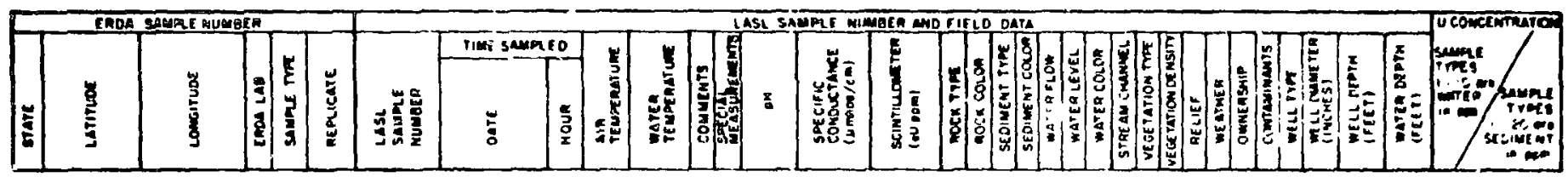

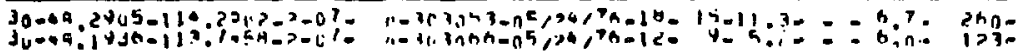

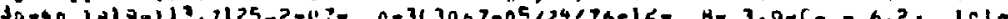

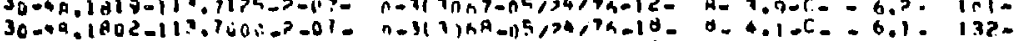

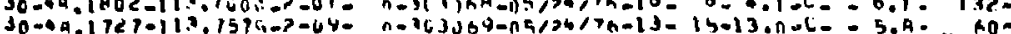

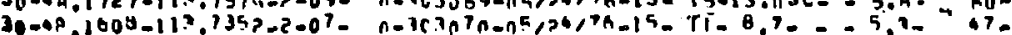

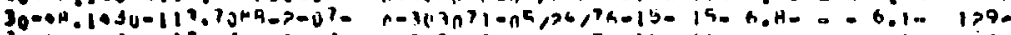

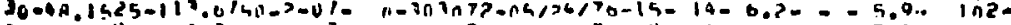

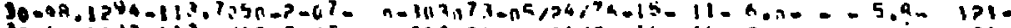

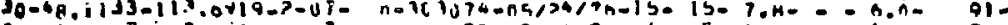

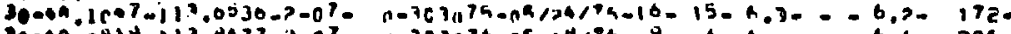
P0.0.01

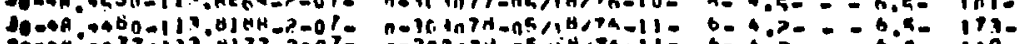

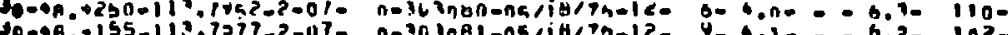

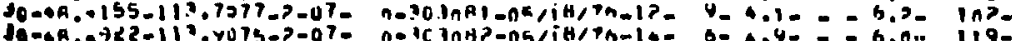

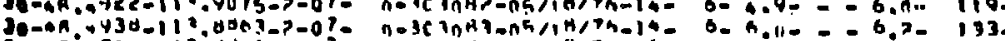

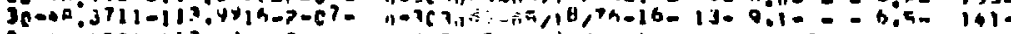

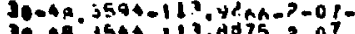

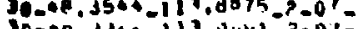

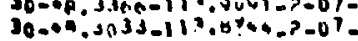

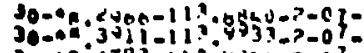
$30-46: 3797-119 ; 4041-7-070$ $30-0$. $3+13-119.4111-7-07-$ $30-0.5012-119,4131-2-01=$

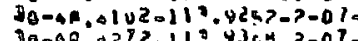

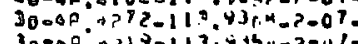

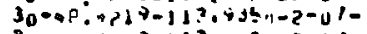
Bocsp.j602-1119803k-3-01:30-0,.J711-113.0300-5-07$30-4 h .3 n 14-113 \cdot 4127=3-07=$

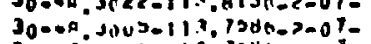

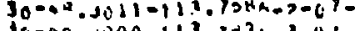

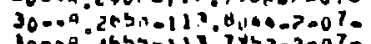
$30-92.25 b 5-111.14320-07-$

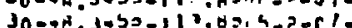

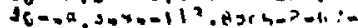

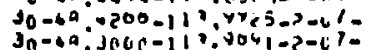

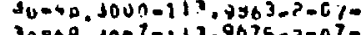

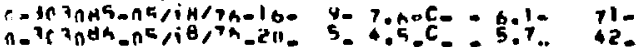

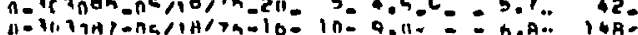

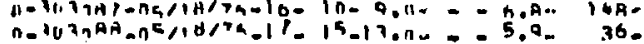

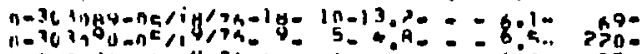

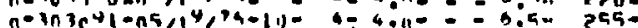

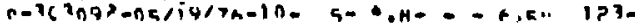

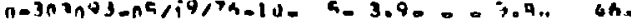

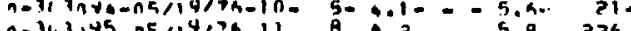
nal,

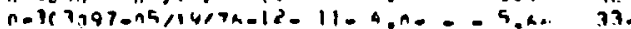

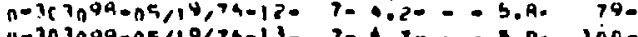
n-1ninga-n5/19/7h-13- 7- A.1- - 5.90 1no-

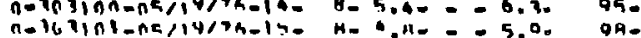

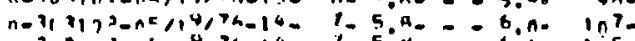

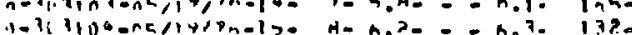

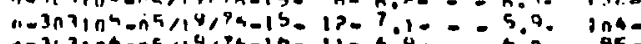
C

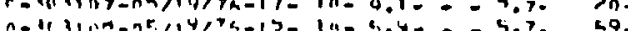

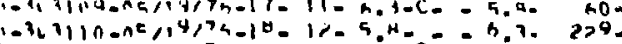

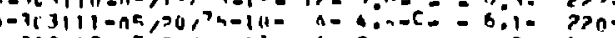
$1-30111 ?=05 / 50 / 74-110$ - $3.4=-6.7 .170-$

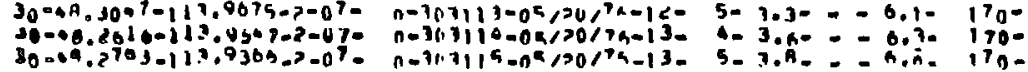
$11-2-7-2-7-4-4-1-2-1-5-5-2--1=0$

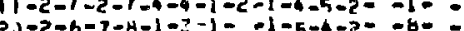
$1>-5=1-5-1-4-4+1-2-1-4-5-5-1=$

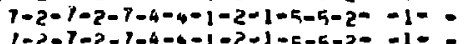
$1-2-7-2-7-4-4-1-2-1-5-5-5-=10=$

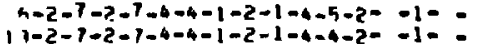
$1 \geq-2-1-2-1-4-4-1-2-1-5-4-2=-2-=$ $1>-2-7-5-1-4-3-1-7-1-4-5-1-3-1-=$

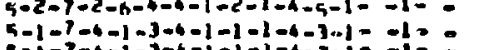
$17-2-7-1-1-5-4-1-2-1=4-5-10-10=$

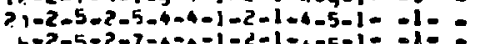
$11-2-5-2-7-4-4-1-2-1-4-5-1=-1=$ $7-1-1-5-6-3-4-2-1-1-4-4-1-=1$
$11-1-1-7-7-4-4-2-2-1-4-4-1--1=$ $11-1-1-7-7-4-4-2-2-1-4-4-1-010$
$17-2-7-2-7-4-9-1-2-1-4-4-1--10$ $13-2-7-2-7-4-4-1-2-1-4-4-1=-1:=$
$1-2-4-3-4-3-4-1-2-1-4-4-1=-10$ $11-1-1-4-1-2-3-1-2-1-6-4-1--1-=$ $11-1-1-4-6-2-3-1-2-1-5-5-1=-1=0$
$4-1-1-4-1-3-4-1-2-1-3-2-1=-1=$

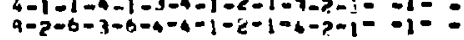
$7-2-7-7-7-4-4-1-2-1-4-7-1-1-1-$

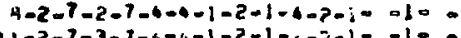

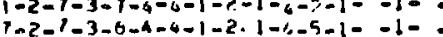
$1=2-7-3-7-4-4-1-2-1-4-3-1=-1-=$ $11-2-4+3-4-5-4-1-2+1-7-5-1=-1=$ $110-2+4-3-6-6-6-1-2-1=3-5-1=-1=$
$10-2-4-3-4-4-4-1-2-1-1-5-10-10=$ $19-2-7-3-7-4-4-1-2-1-5-5-1--10:$ $14-2-1-7-7-3-4-1-2-1-4-5-1=-1-=$

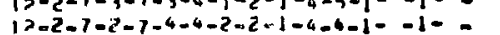

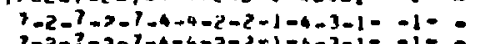

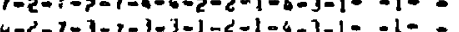

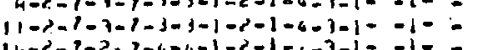
$5+1-1-4-1+3-4-1-2-1-7-?-1=-1=$
$4-1-1-1-7-4-4-1-2-1-4-5-6=-1=$ $17=1-1=3-7-4-4-1-2-1+n-5-3--1=$

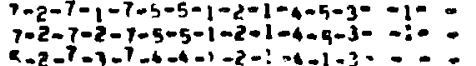




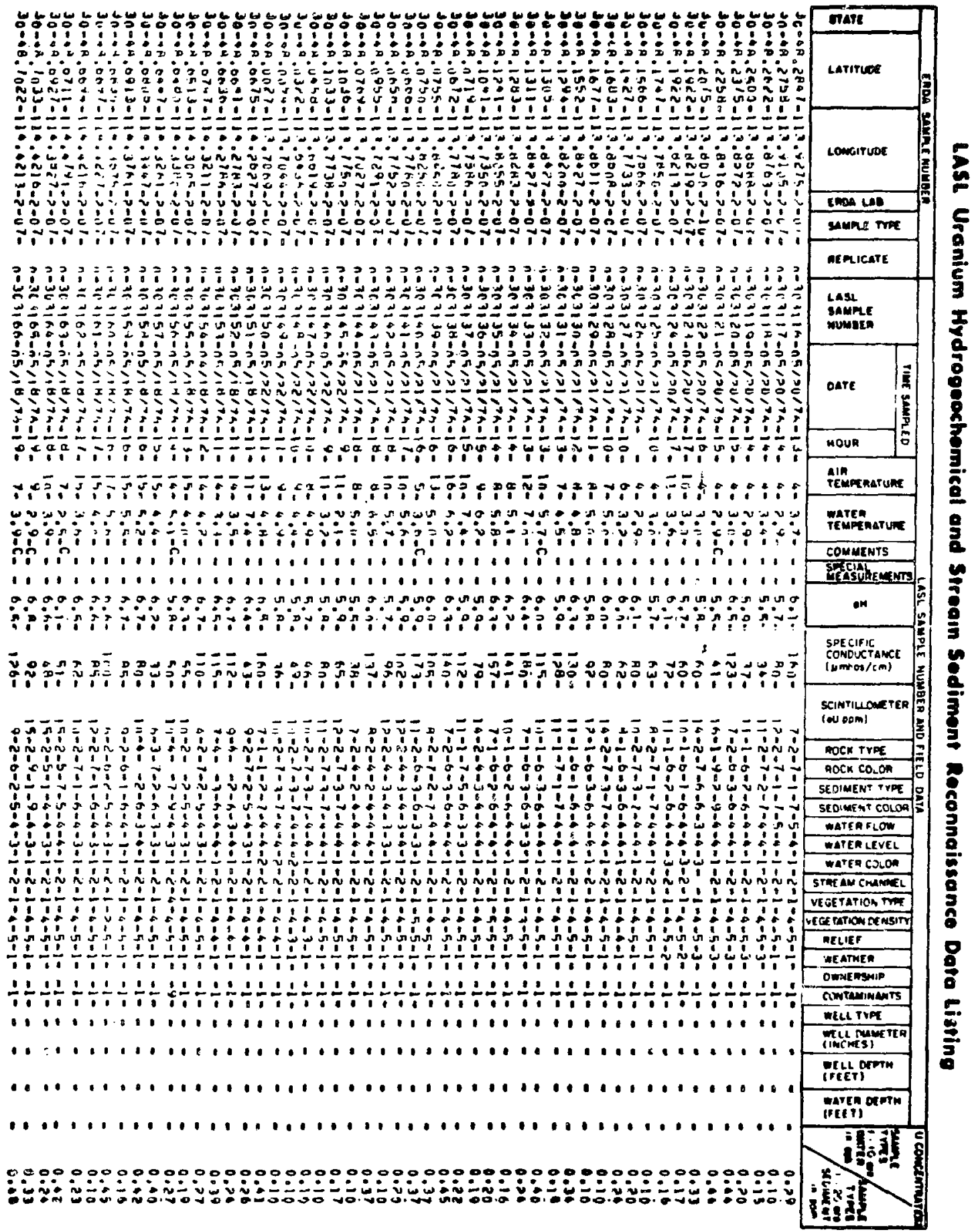




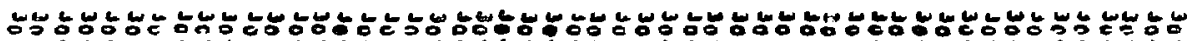

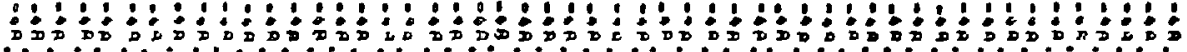

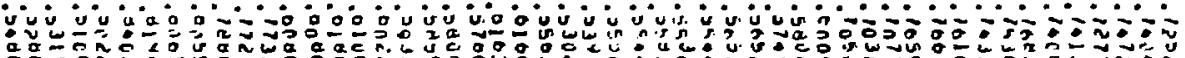
a

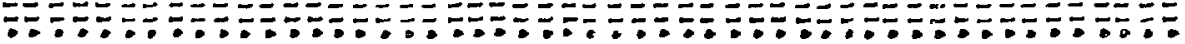
o : :

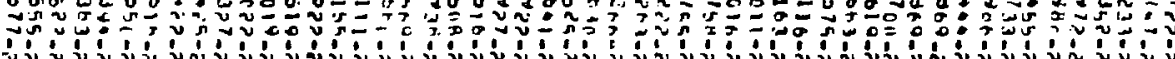

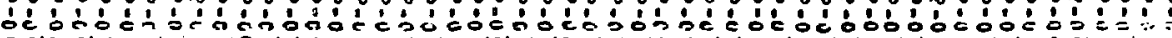

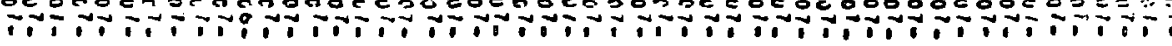

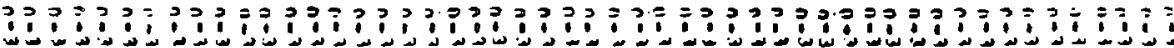

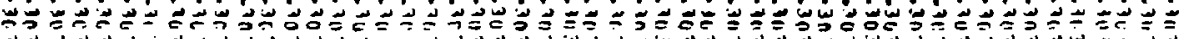

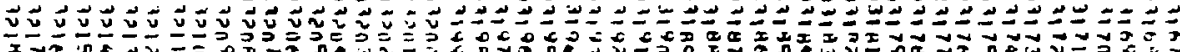

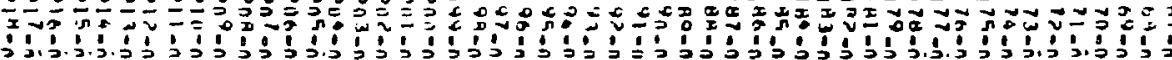

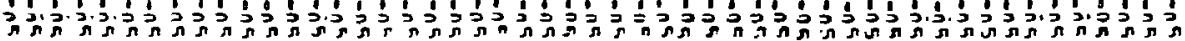

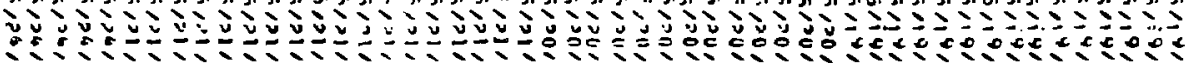

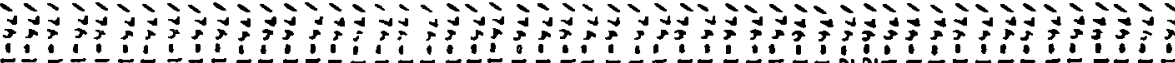

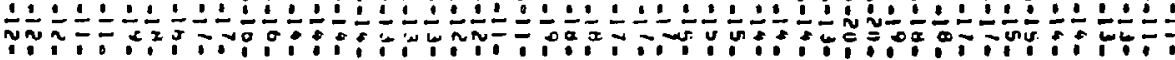

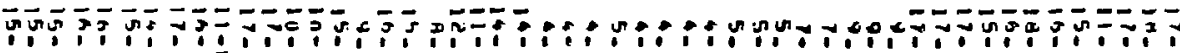

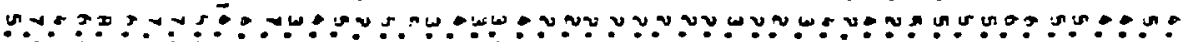

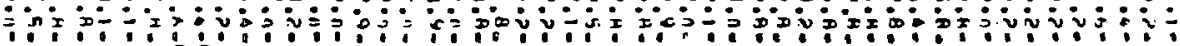

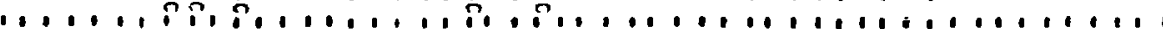

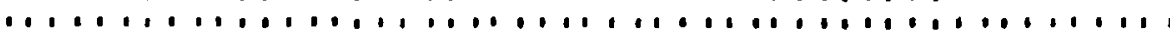

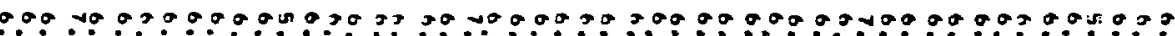

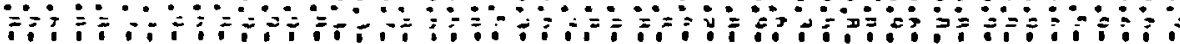

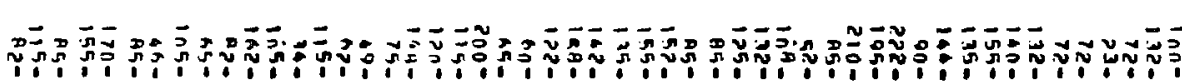

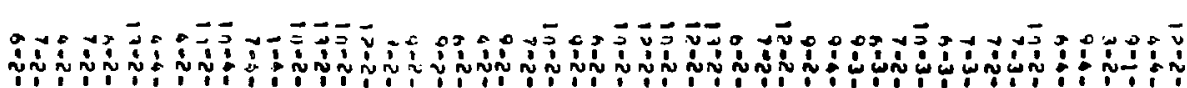

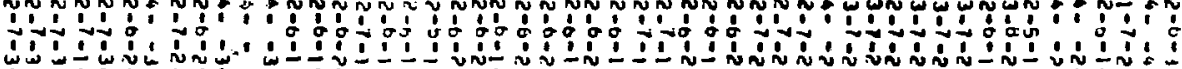

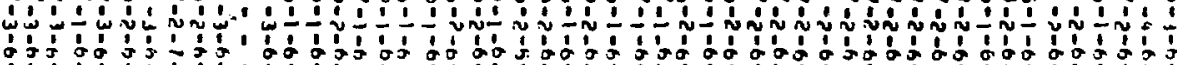

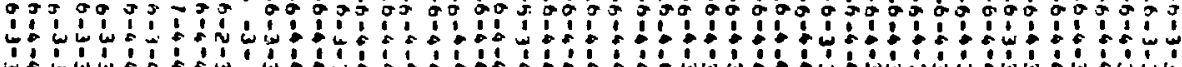

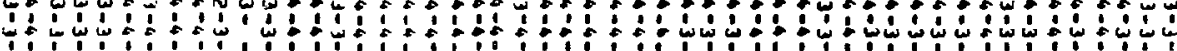

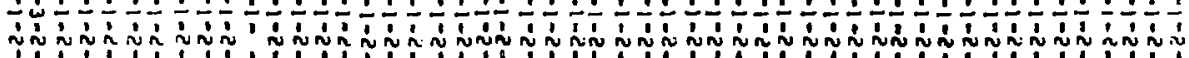

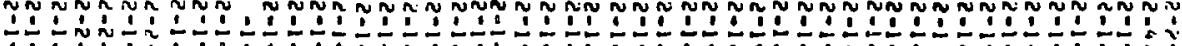

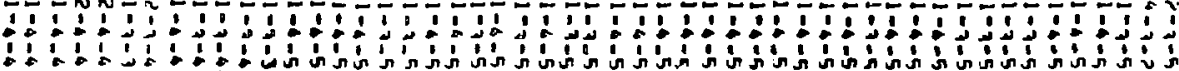
:

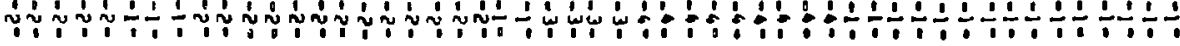

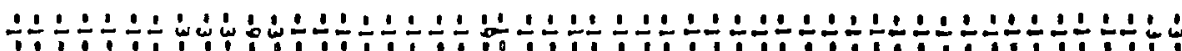

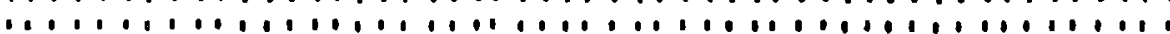
$, \ldots, \ldots, \ldots, \ldots, \ldots, \ldots, \ldots, \ldots \ldots, \ldots \ldots, \ldots, \ldots, \ldots, \ldots, \ldots, \ldots \ldots \ldots, \ldots \ldots$

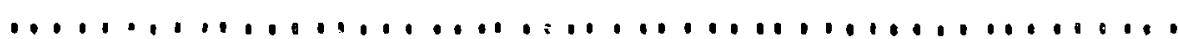

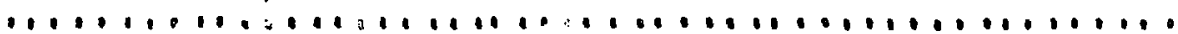
000900009000090000009090900900009000090000900900000

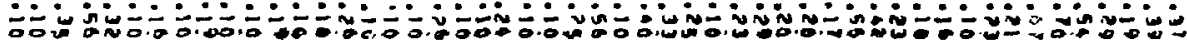

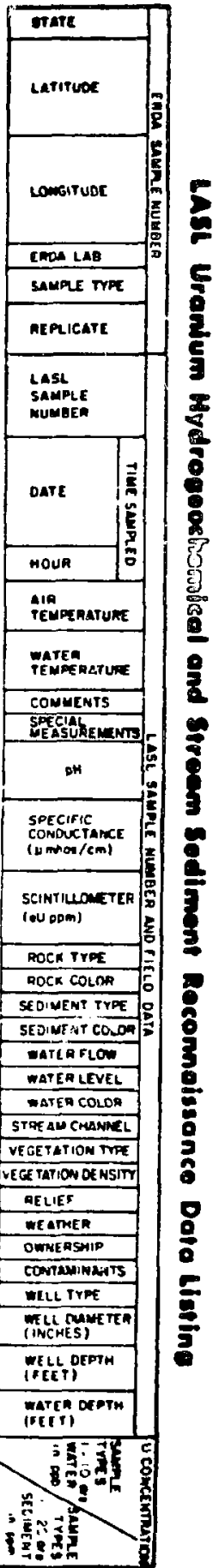




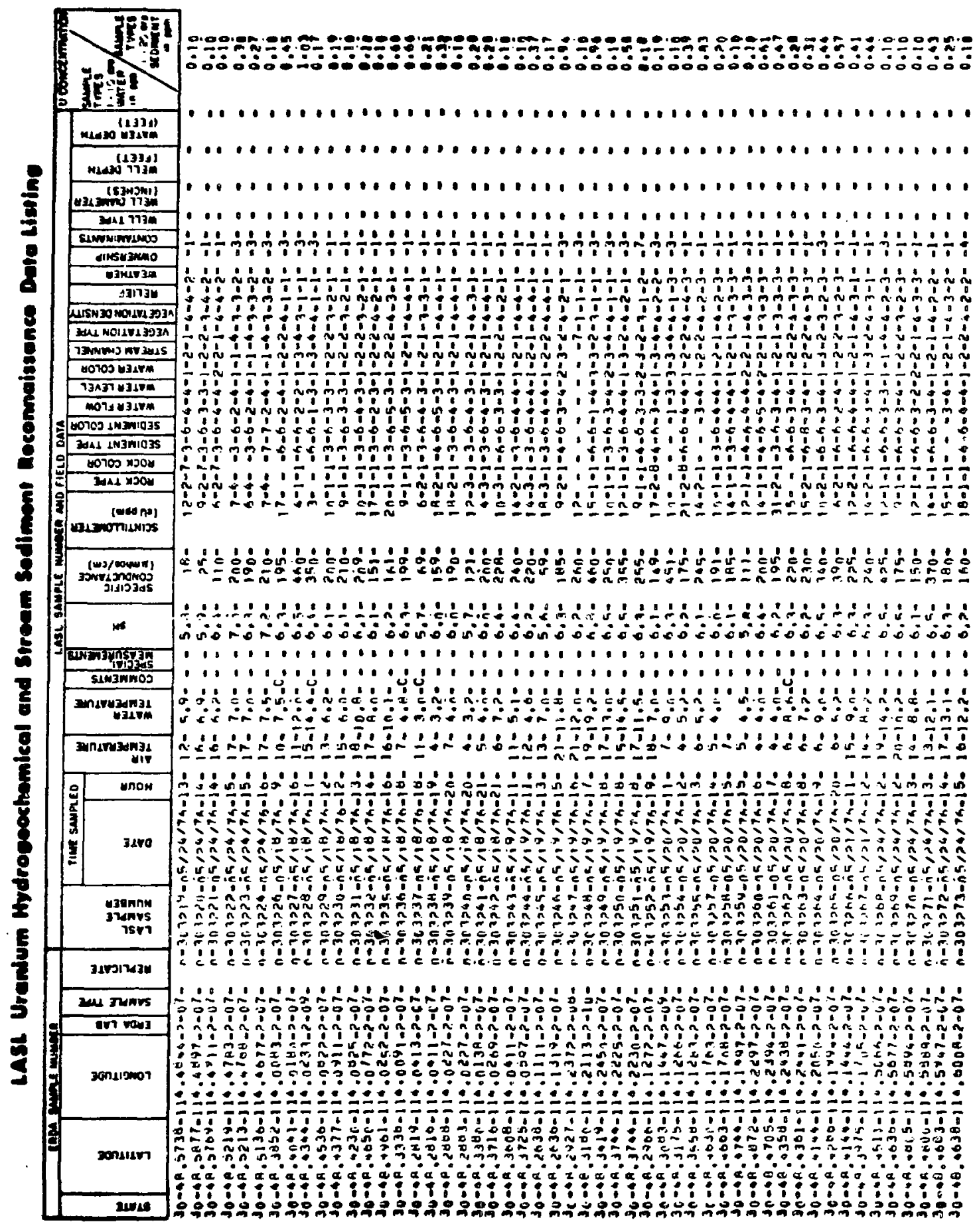




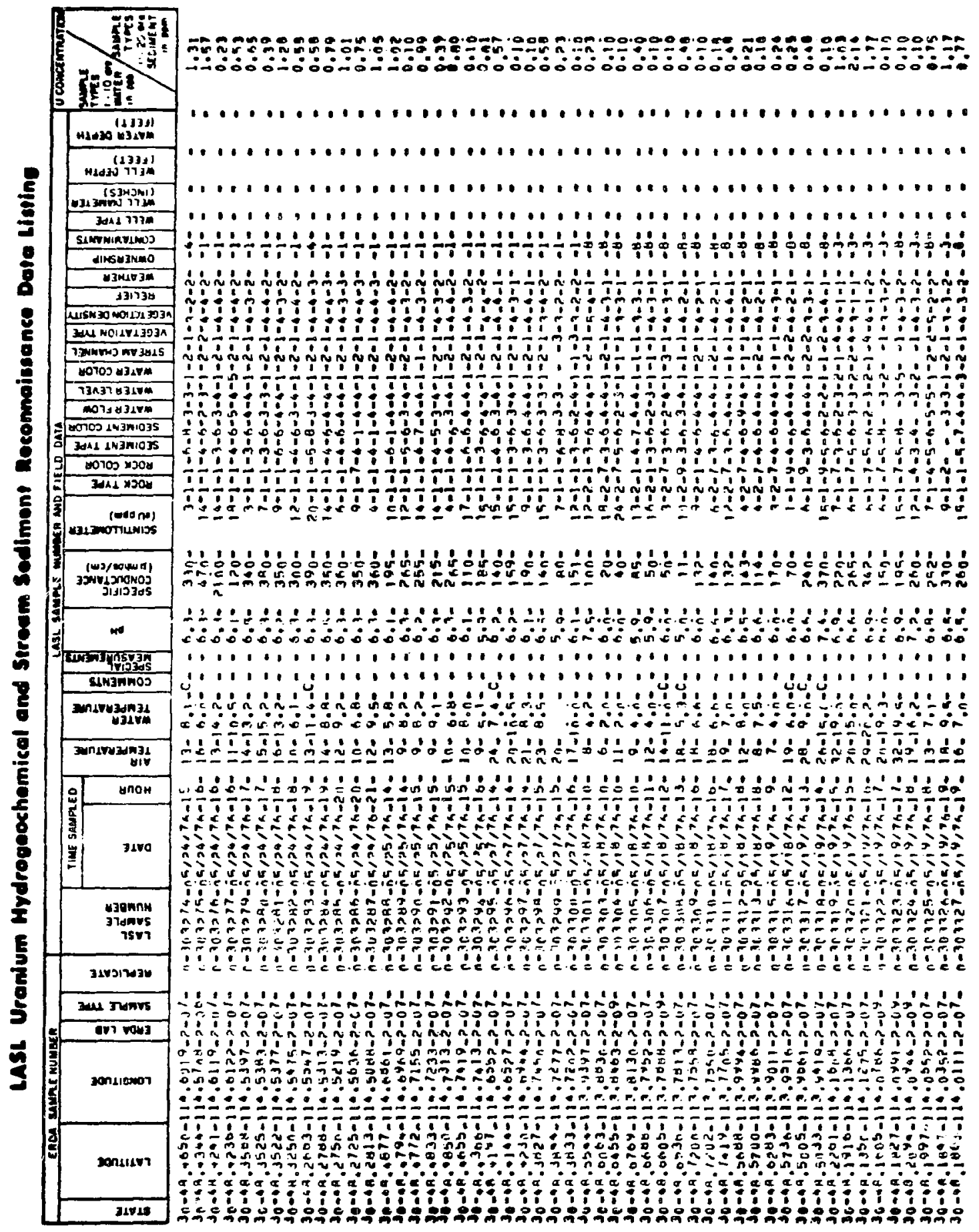


LASL Uranium Mydrogecchemical and Streem Sediment Reconnaisanance Date Listing

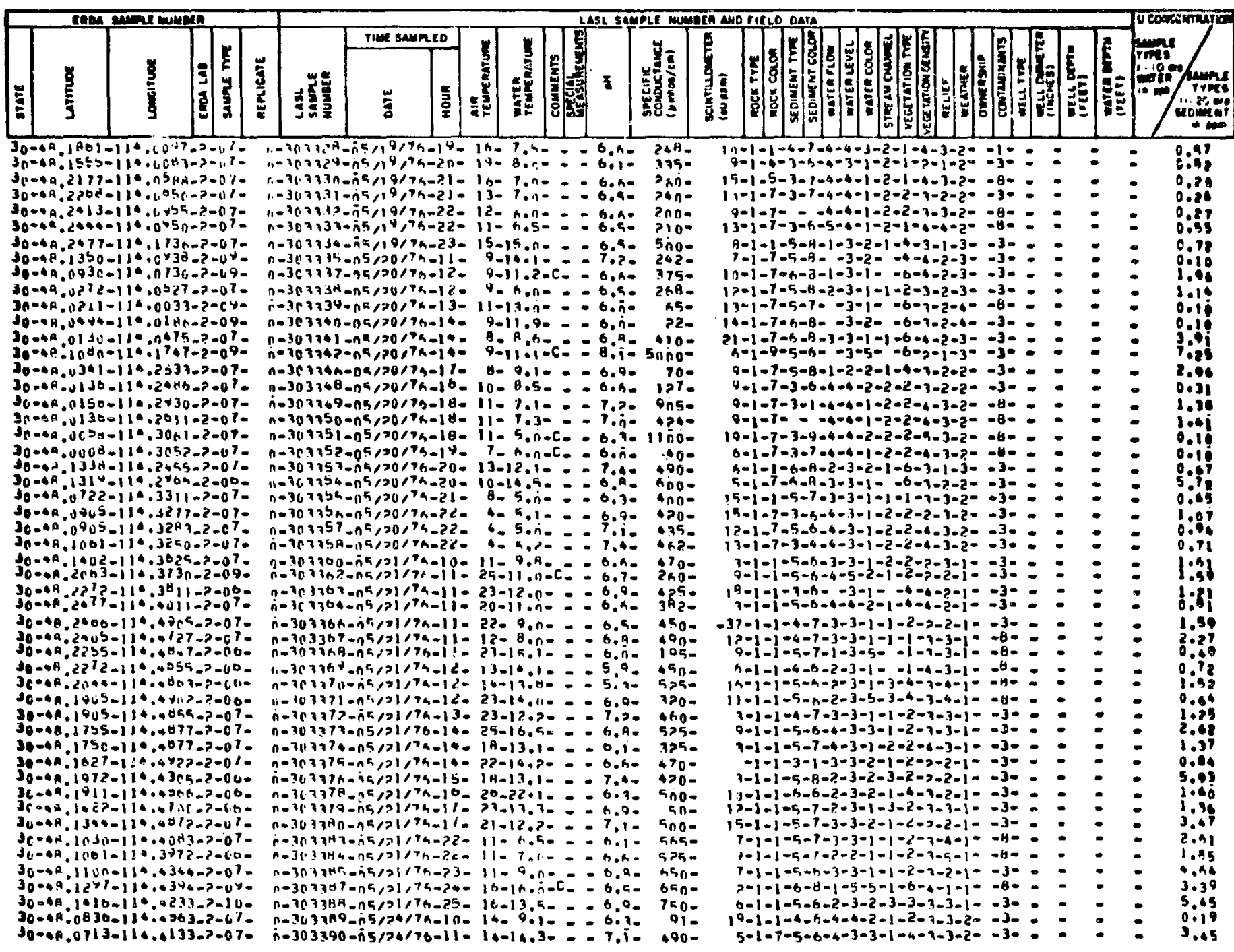




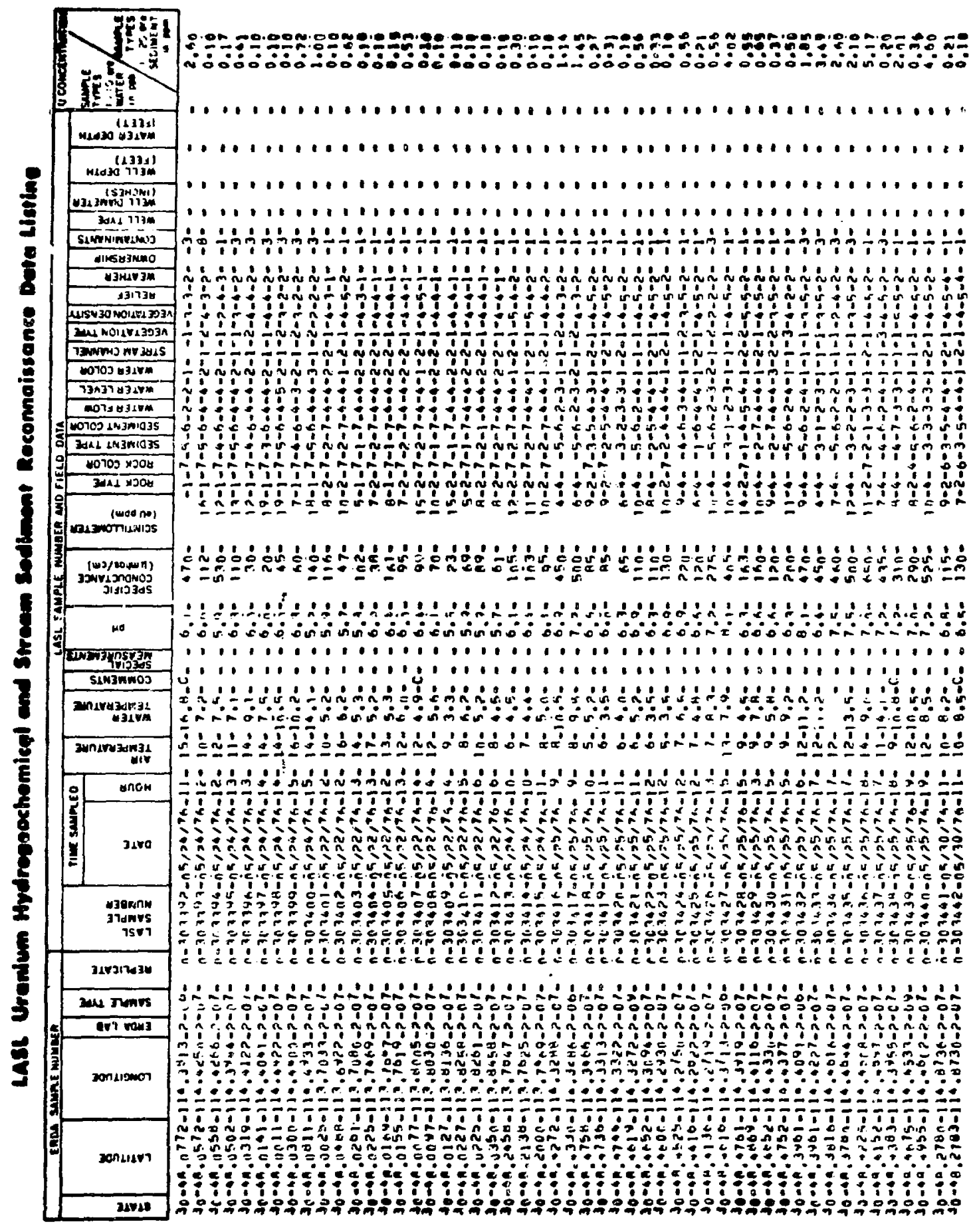




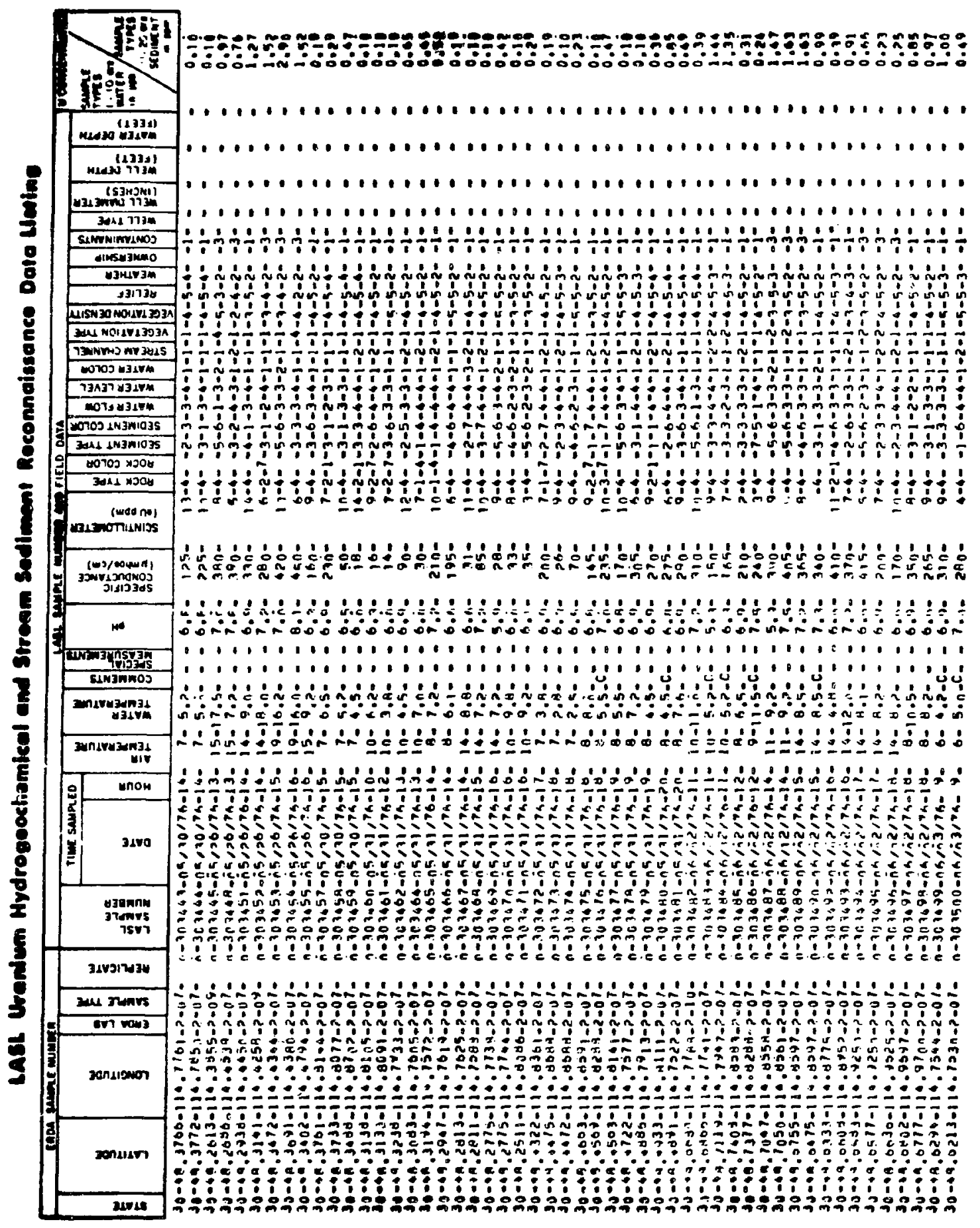




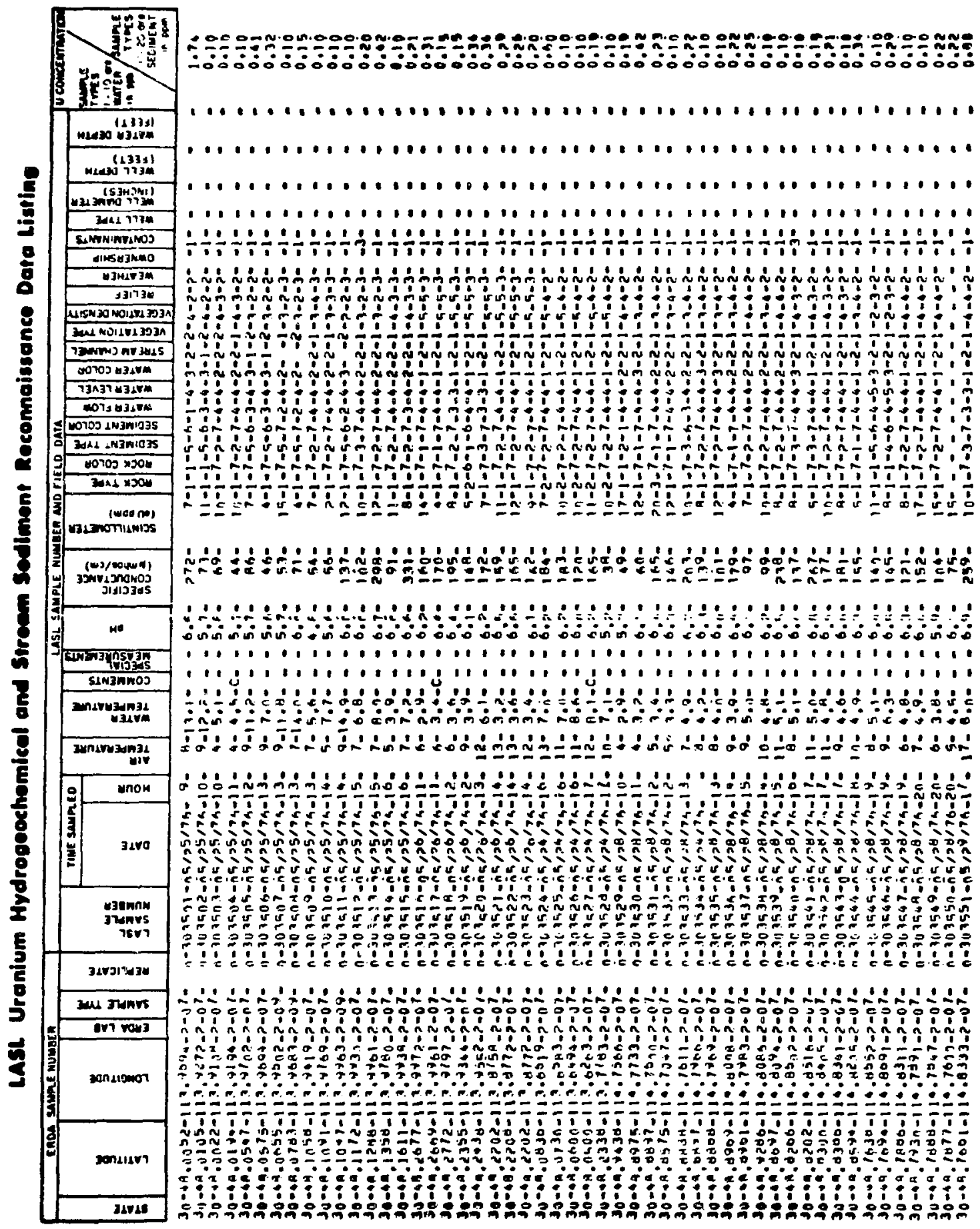




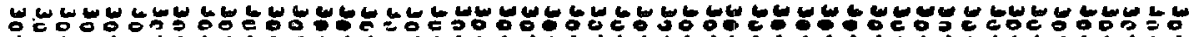

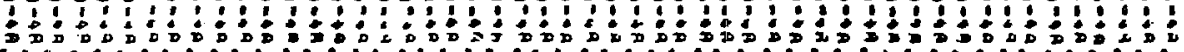
a a

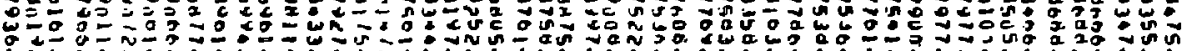

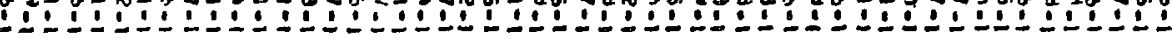

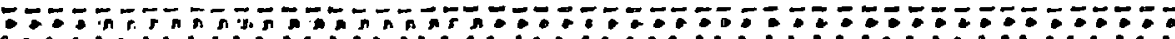

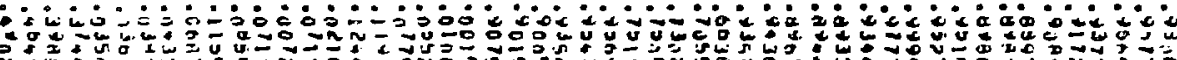

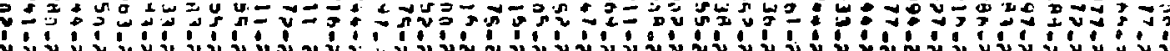
ó

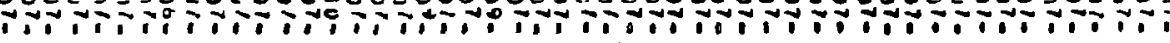

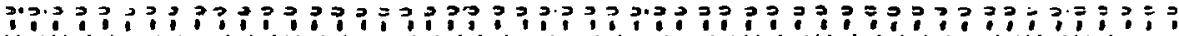

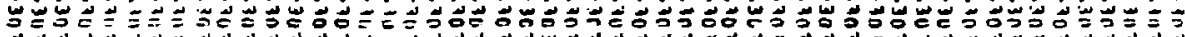

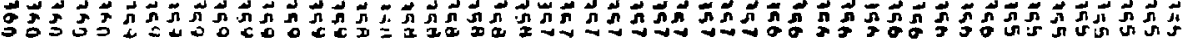

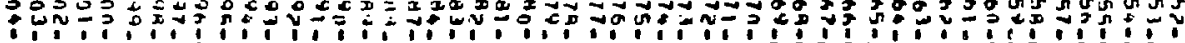

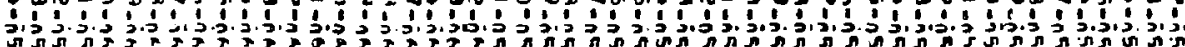

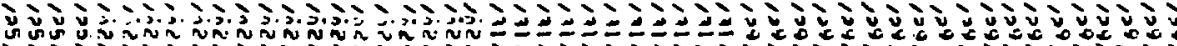

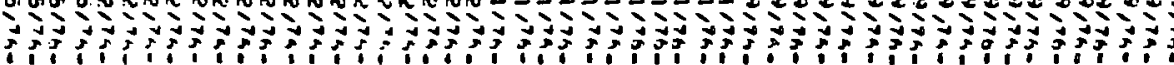

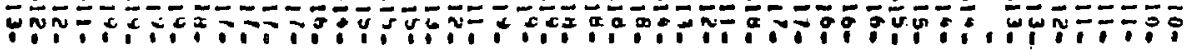

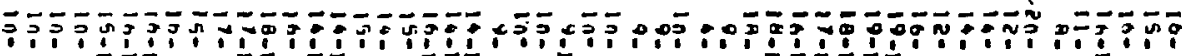
: 1:

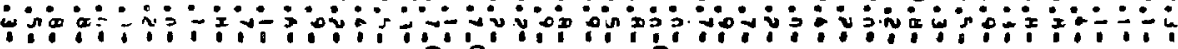

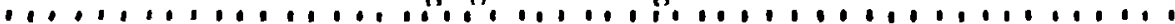

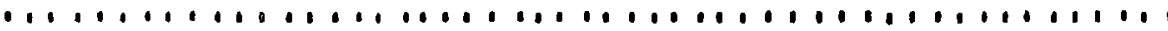

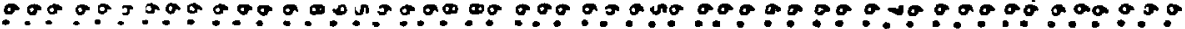

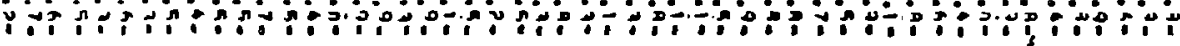

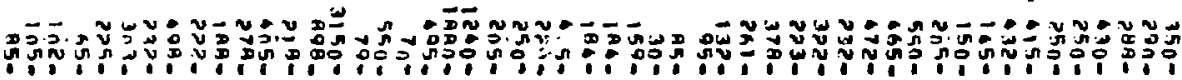

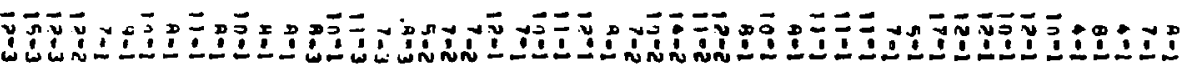
4

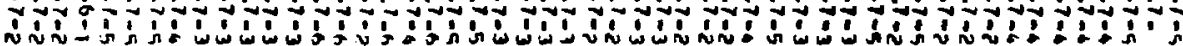

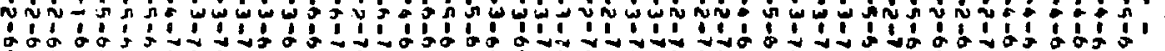
1:

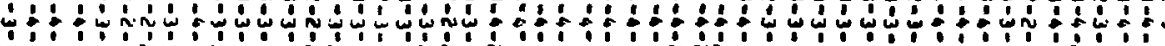

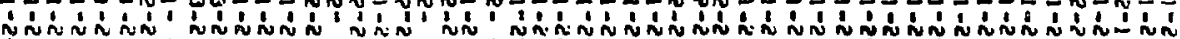

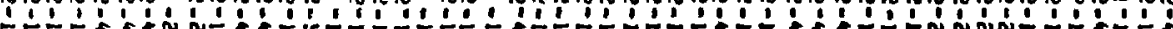

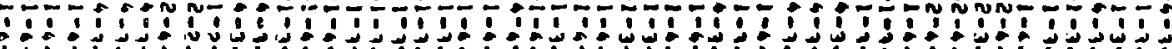

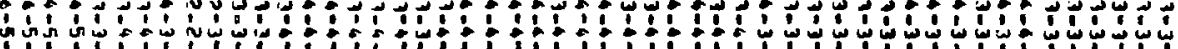

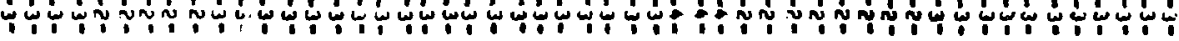

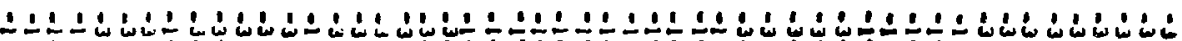

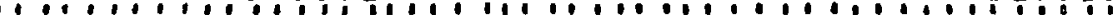

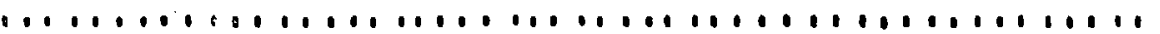

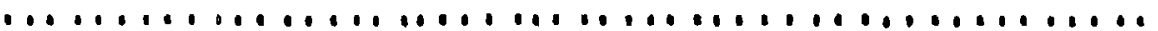

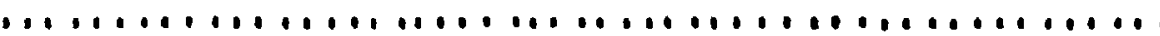

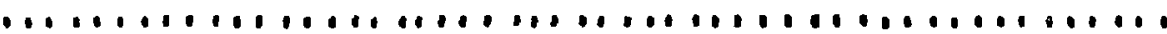

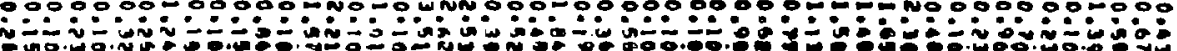

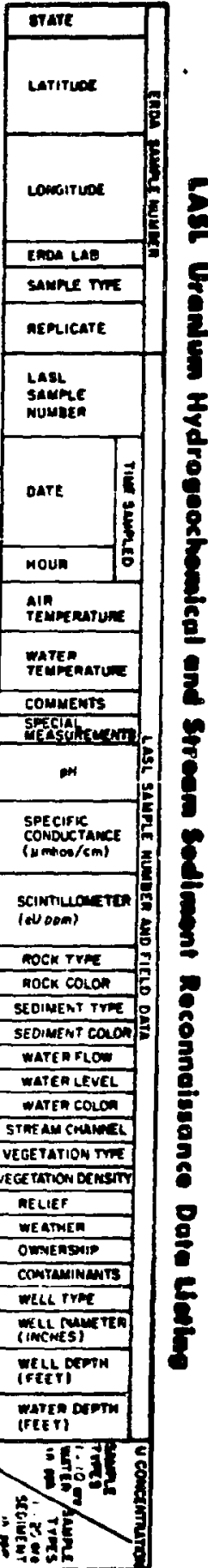




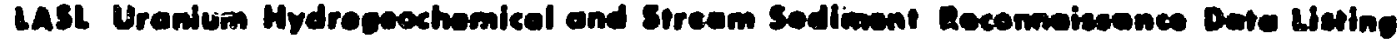

\begin{tabular}{|c|c|c|c|c|c|c|c|c|c|c|c|c|c|c|c|}
\hline \multirow[b]{3}{*}{ ह } & \multirow[b]{3}{*}{$\frac{5}{3}$} & \multirow{3}{*}{ 旁 } & & & \multirow[b]{3}{*}{ 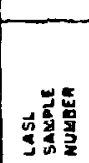 } & \multirow{2}{*}{\multicolumn{2}{|c|}{ TIME SAMPLEO }} & \multirow{3}{*}{\multicolumn{2}{|c|}{ 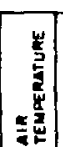 }} & \multirow{3}{*}{ 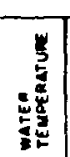 } & \multirow{3}{*}{ 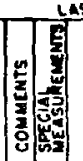 } & & & \\
\hline & & & & & & & & & & & & & & \multirow{2}{*}{ 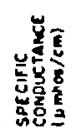 } & \\
\hline & & & & & $\frac{\pi}{\tilde{d}}$ & & & 9 & & & & & & & \\
\hline
\end{tabular}

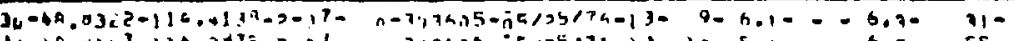

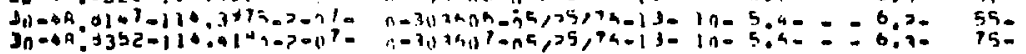

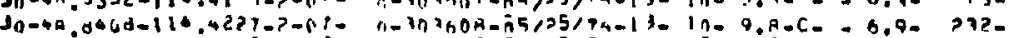

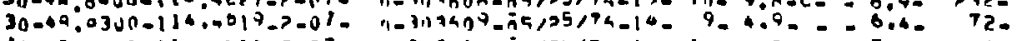

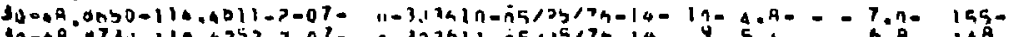

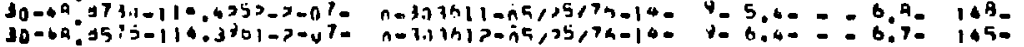

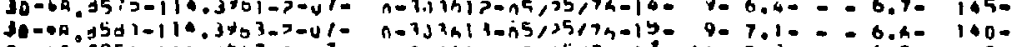

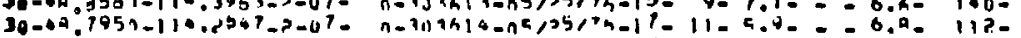

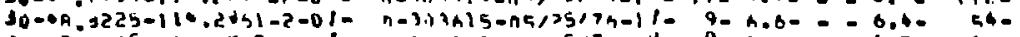

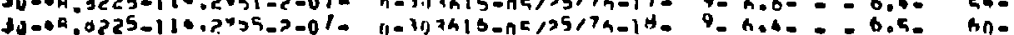

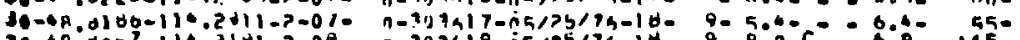

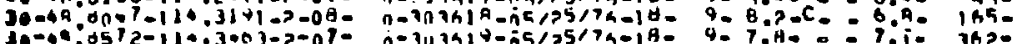

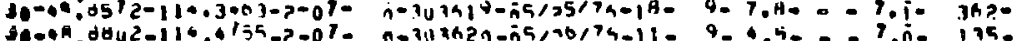

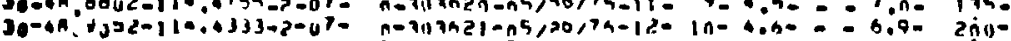

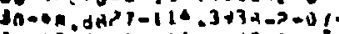

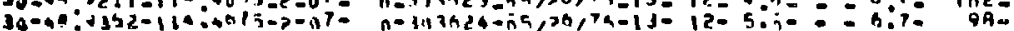

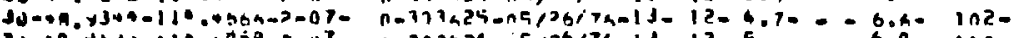

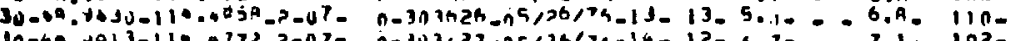

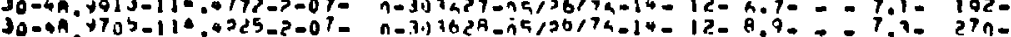

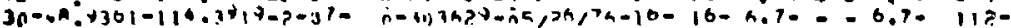

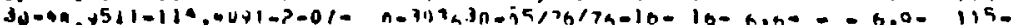

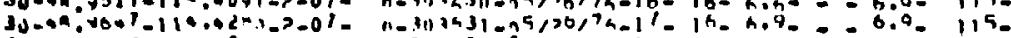

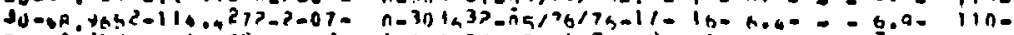

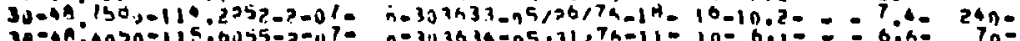

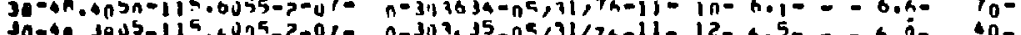

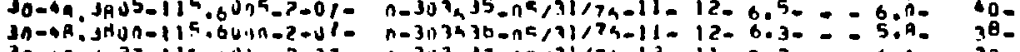

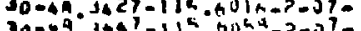

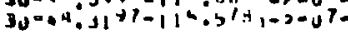
$3000,3033-112,3+61-7-61-$

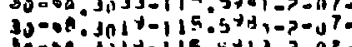

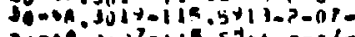

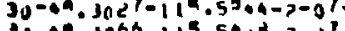

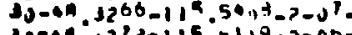

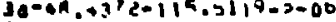
$30-40 .+435-115,5377-7-n)$

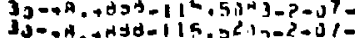

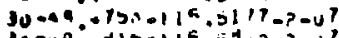

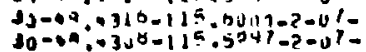

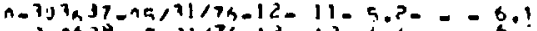
a

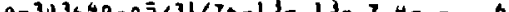
$0-10140$ $n=103703-n 9 / 217 A-15-14-5.5=-5.7=21-$

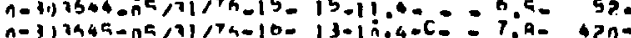

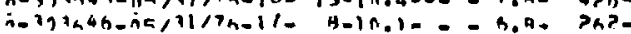

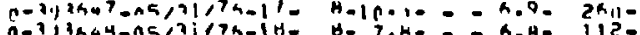

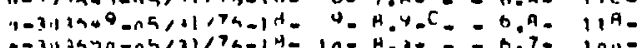
?-31) $3451-n 5,1179-1 d-11-A_{0} 4_{-}=? \cdot 1-145-$

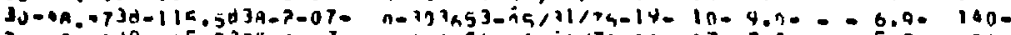

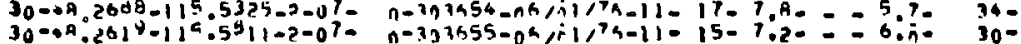

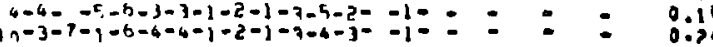
$104--5-6-3-4-1-2-4-3-4-3=-10-0=0$

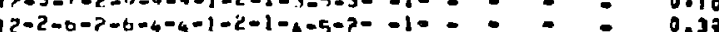

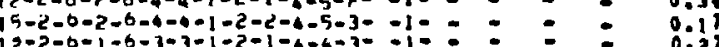
$1>-2-6-2-6-4-4+1-2-1-4-4-3--1-0-0.0 .10$ $4-2-7-7-t-4-6-1-2-1-4-4-5-3--1-=-0.00$ $3-2-7-2-6-4-6-1-2-1-4-4-4-3--1-=-0=0.2$ n-2-7-2-6-4-4-1-2-1-4-4-3--1- - - - - 0.1

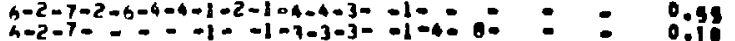
$13=4--5-6-3-5-1-2-1-3-3-3--10-\square=0.64$

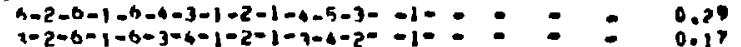
$17-2-1-2-6-4-4-1-2-1-4-4-2--10=0.1 ?$ $15-2-0-3-6-4-4-1-2-1-4-3-2=-10=: 000$ $0-2-7-1-6-4-4-1-2-1-4-4-2--1-=-0=0.82$ $0-4--2-6-4-4-1-2-2-7-3-2=-1-0=0.10$ $6=4--3-6-3-4-1-2-2-2-3-2--1=-0.19$ $3-2-1-2-h-4-3-1-2-1-4-4-7--1-0-0=0.19$ $4-2-7-2-6-4-3-1-2-1-4-4-?-1-=-\quad-\quad 0.42$

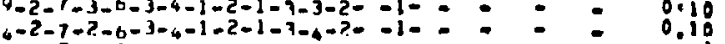
$9-2=7-3-6-1-4-1+2-1-7-3-2=-1-:=:=0.10$ $12-2-7-2-6-3-3-1-2-1-4-4-4--10-0-0.20$

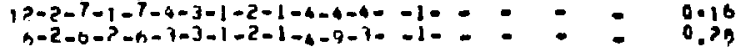

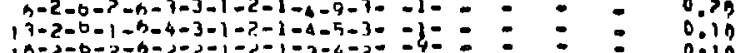

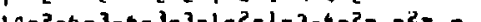

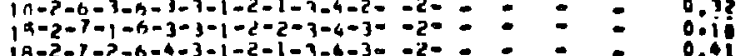
$18-2-7-7-6-4-3-1-2-1-7-4-3--2-:=: 001$ $13-2-7-3-6-3-3-2-2-2-7-3-3--30=: \quad: \quad=0.31$ $1,1-4--3-4-3-3-1-2-1-3-4-4--1-0:-$

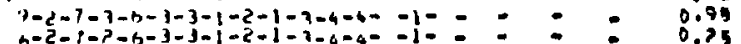
$1>-2-1-1 ;-6->-6-1+2-1-4-h-4=-1-\div:=0.07$ $10-2+7-2-6-1-3-1-2-2-1-4-2--3-:=:=0.45$ 10

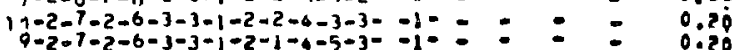




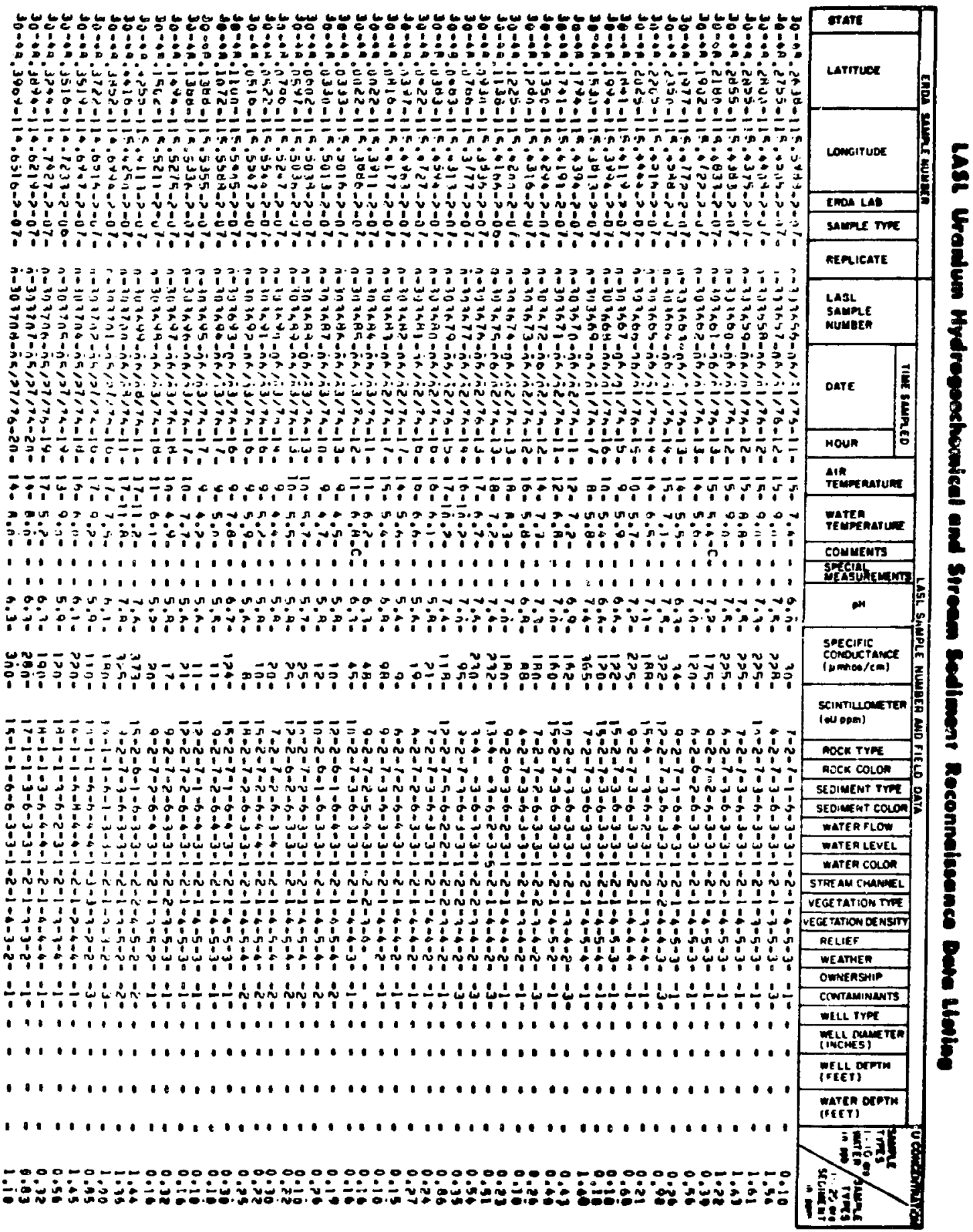




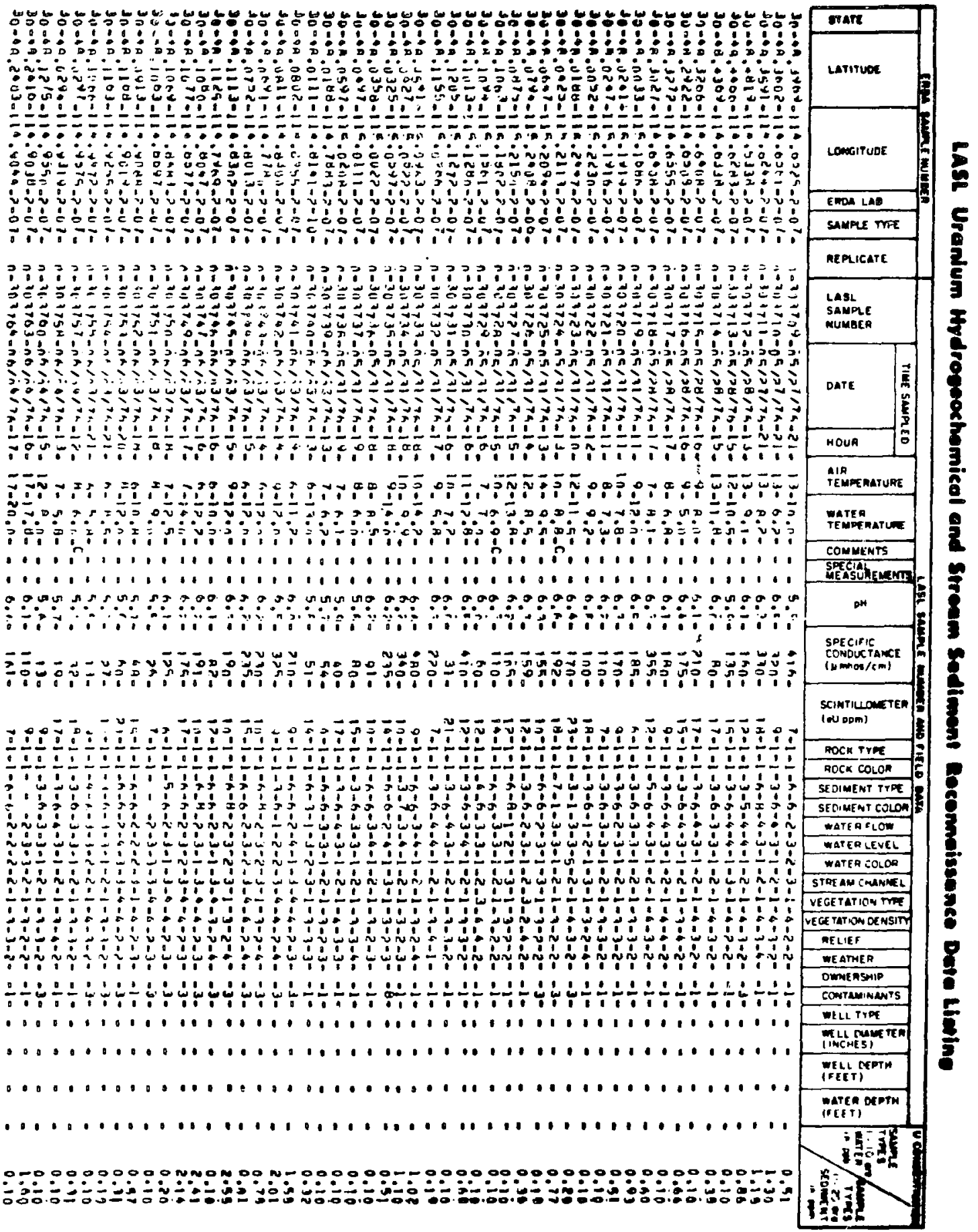




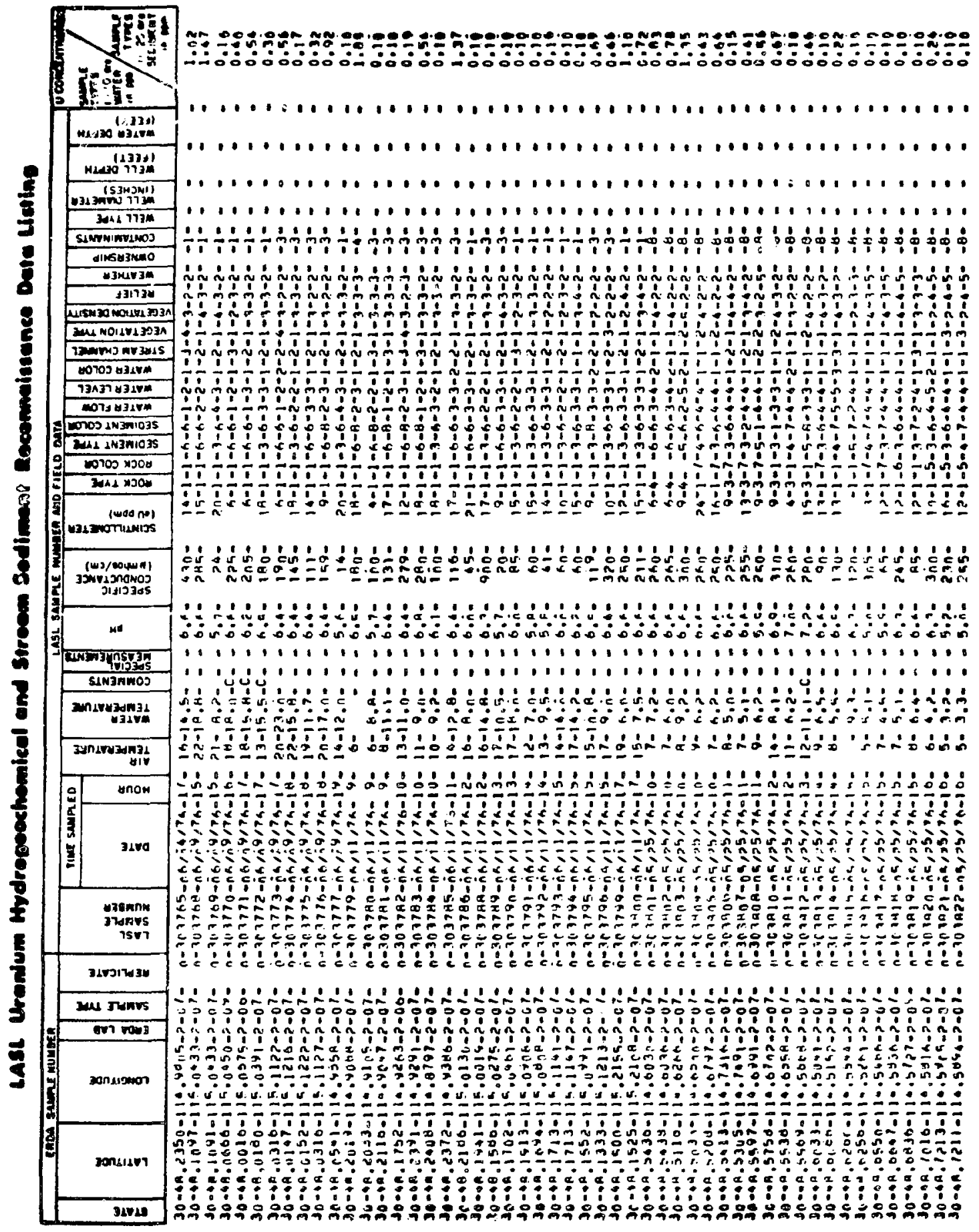




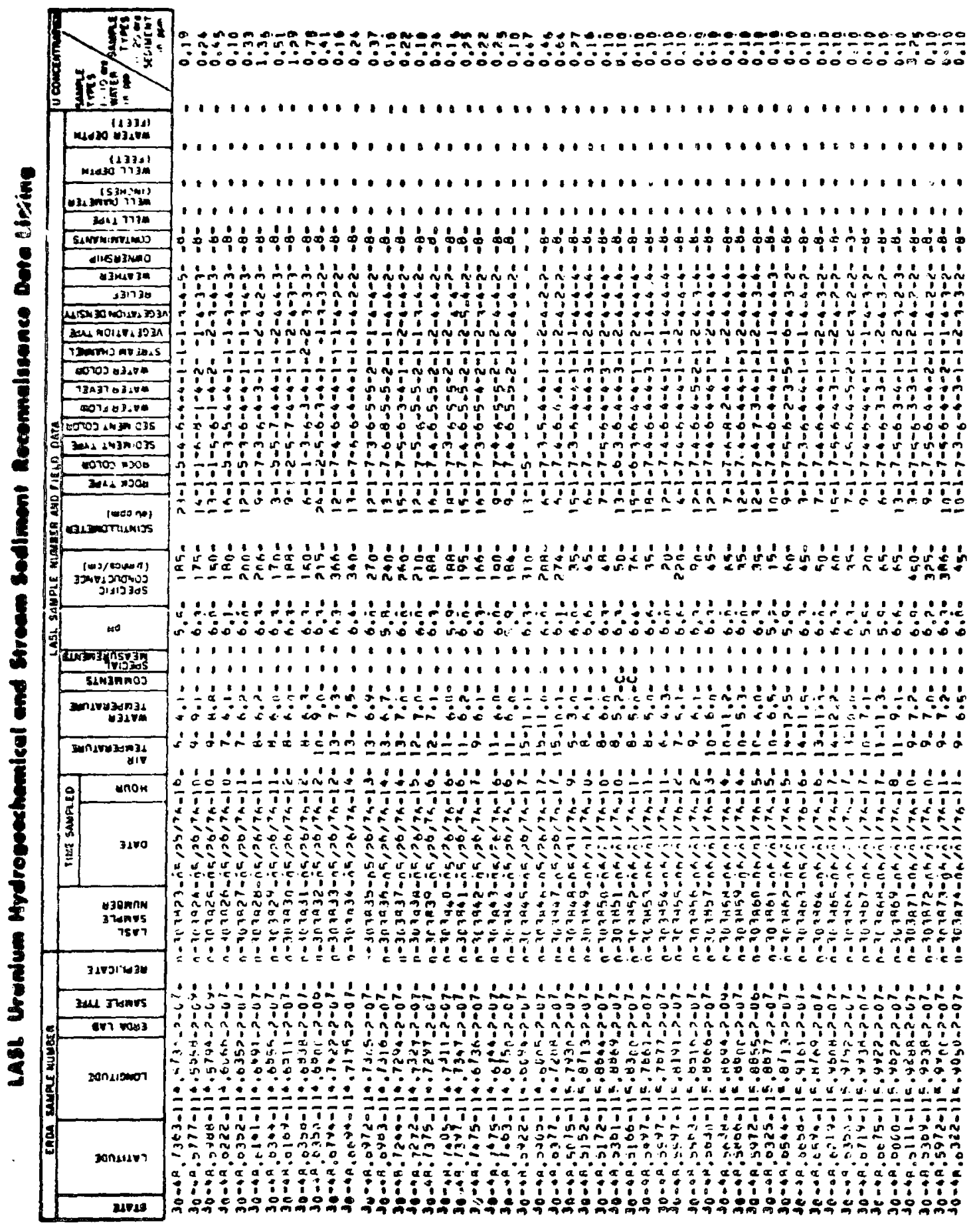




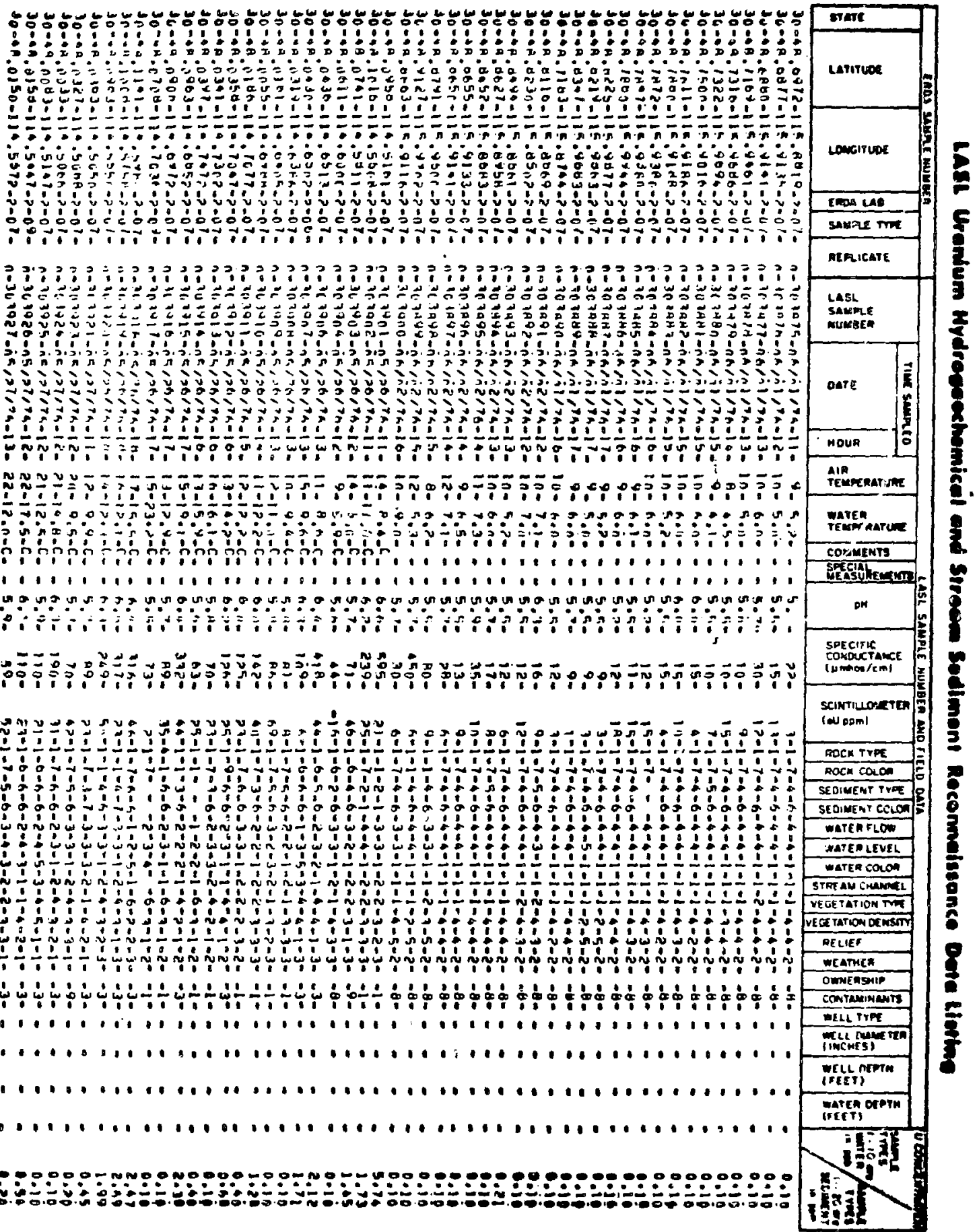




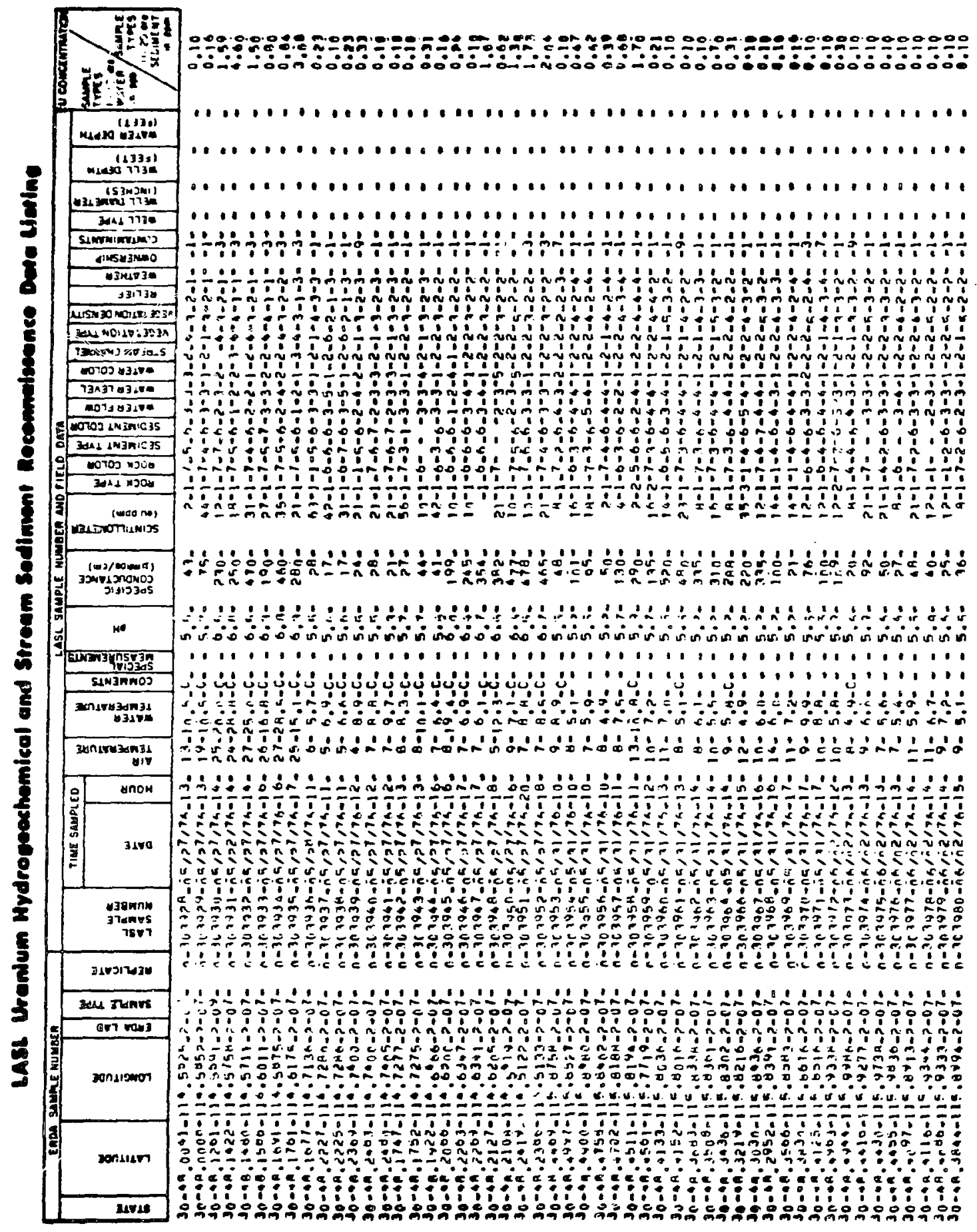




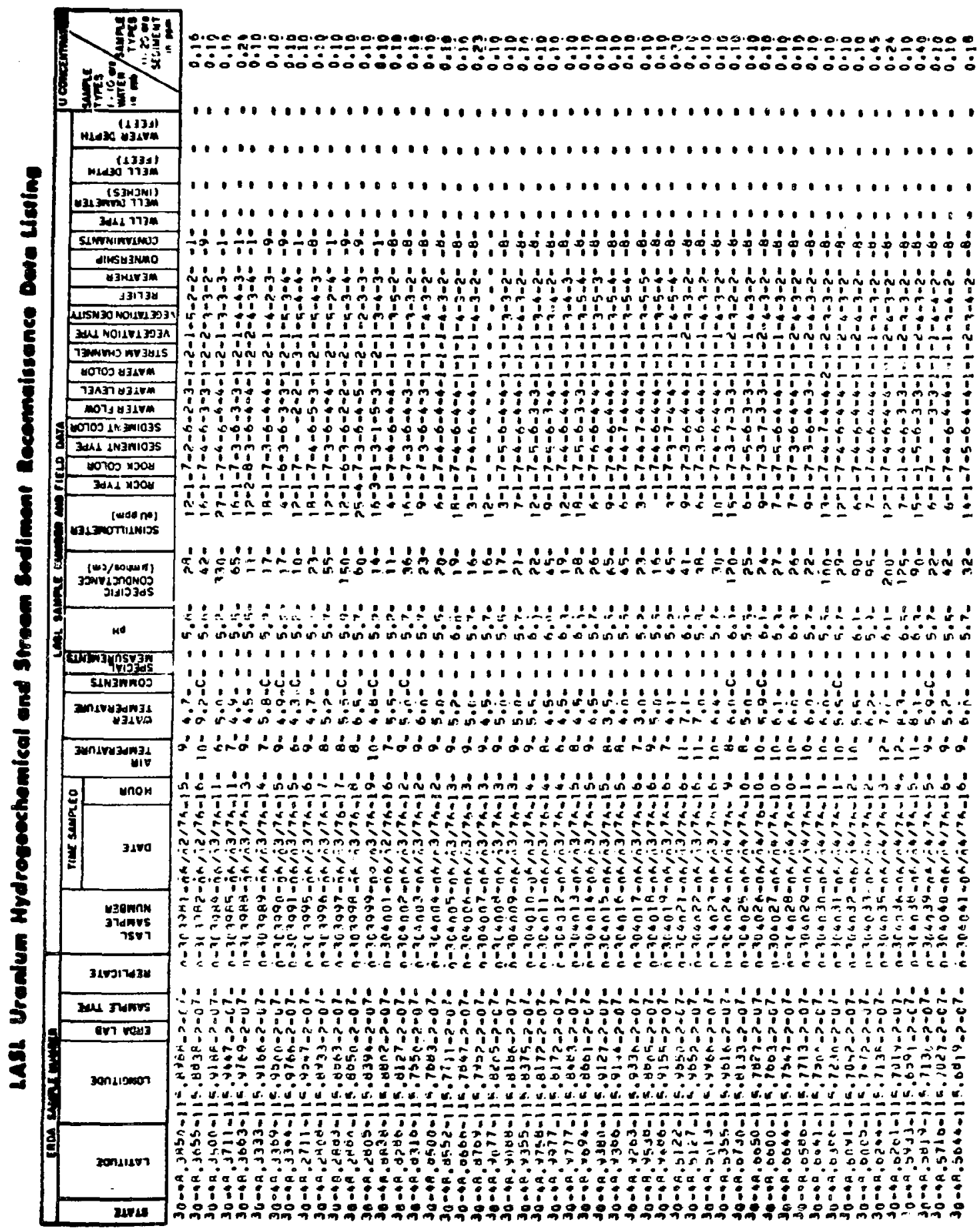




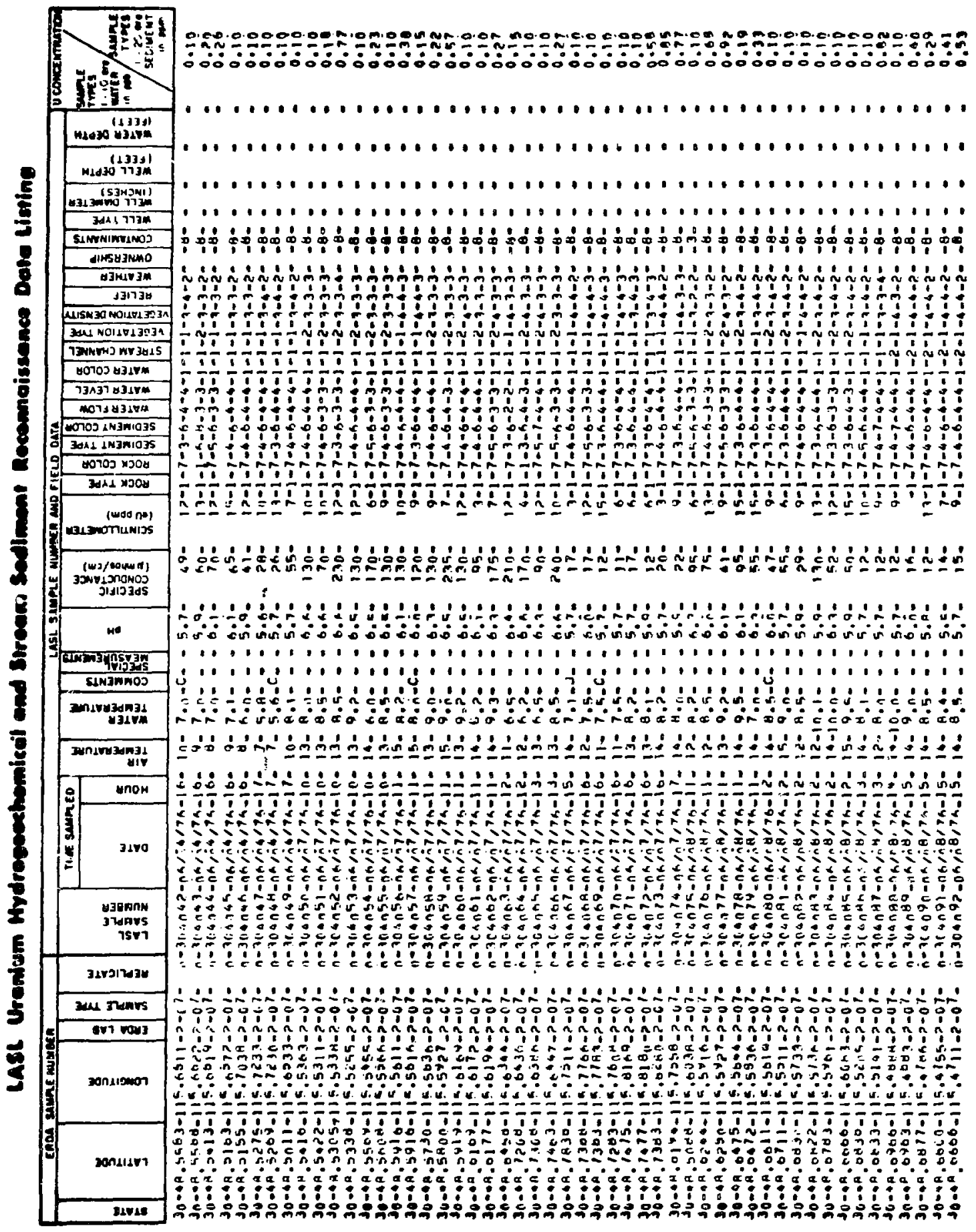




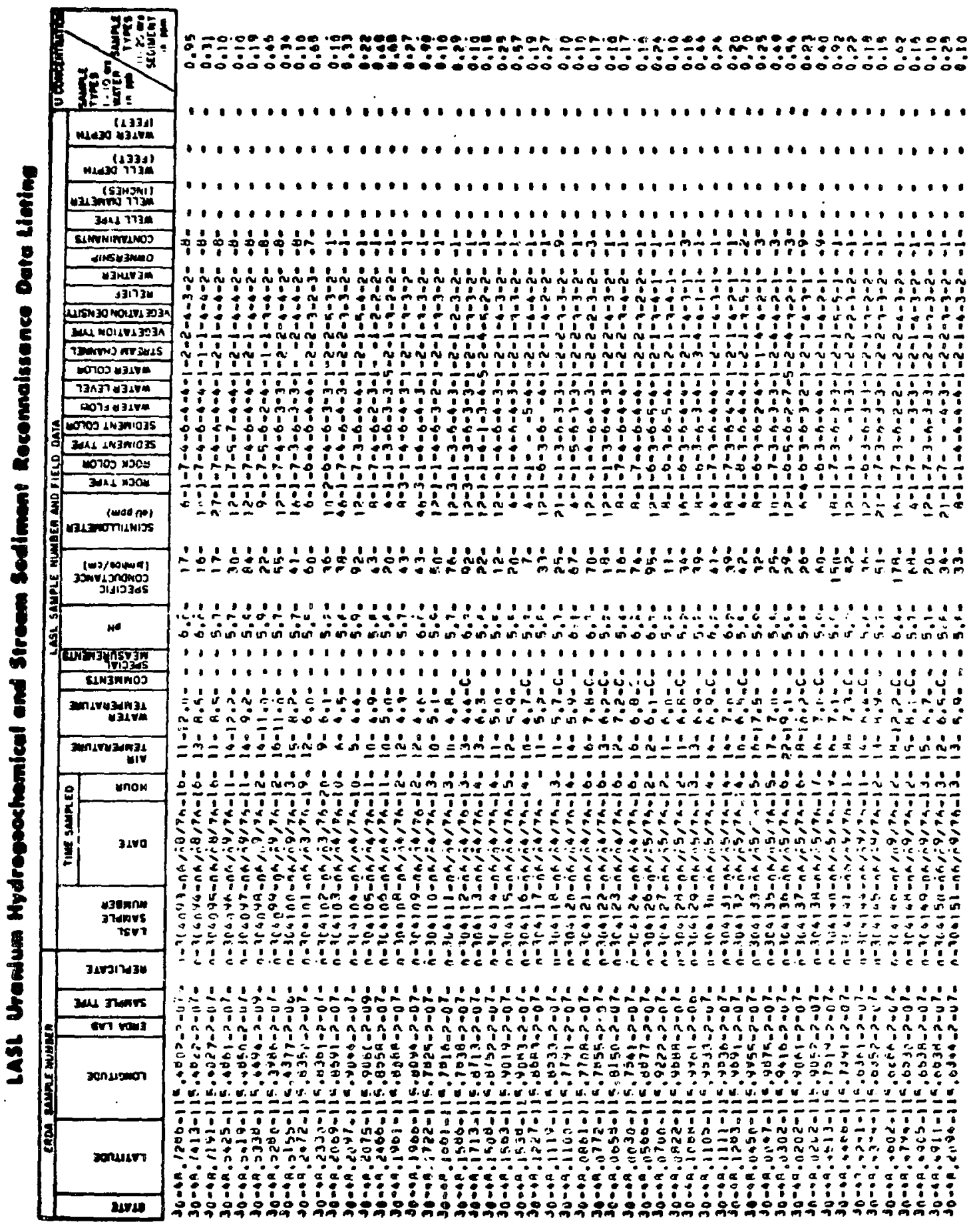




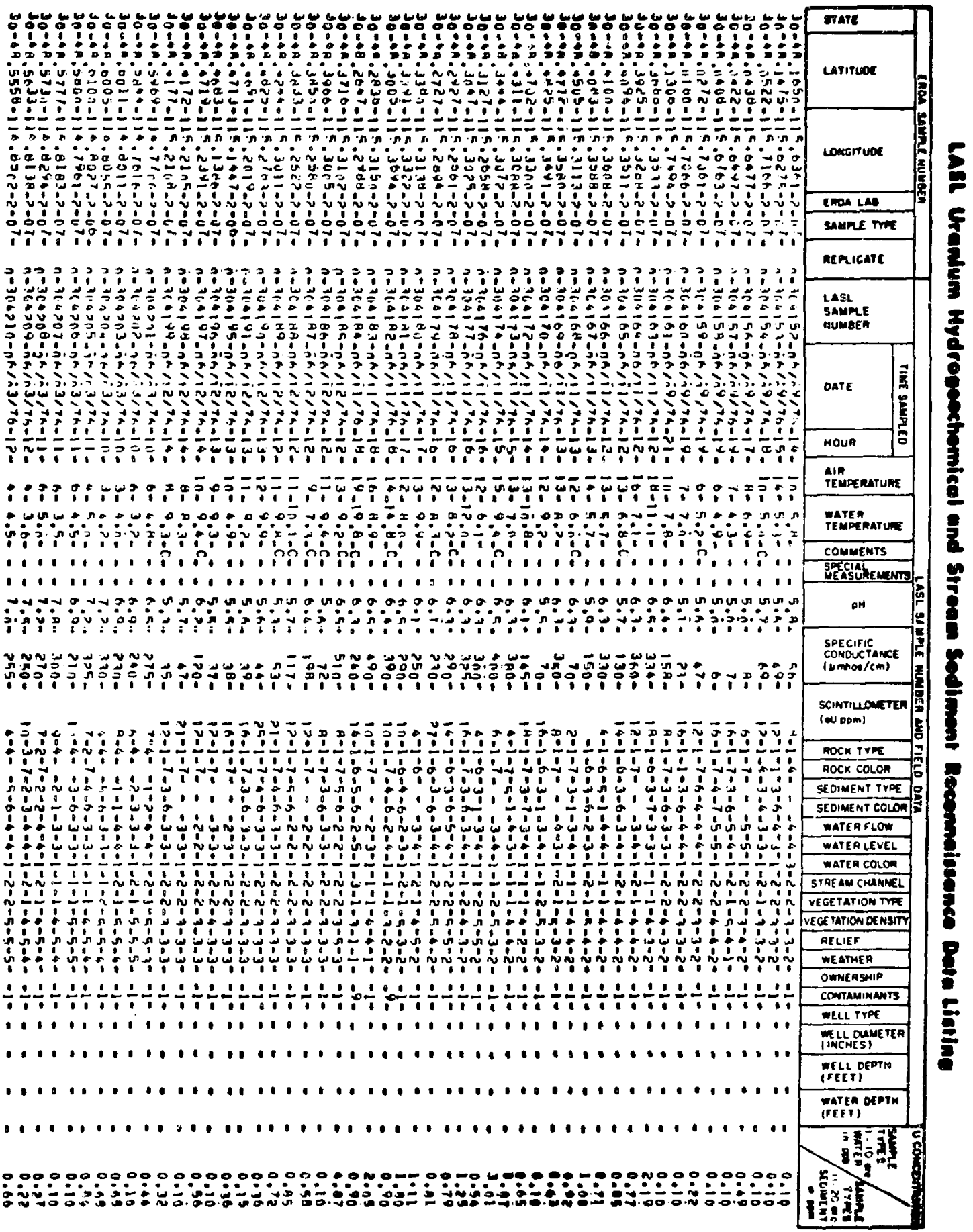




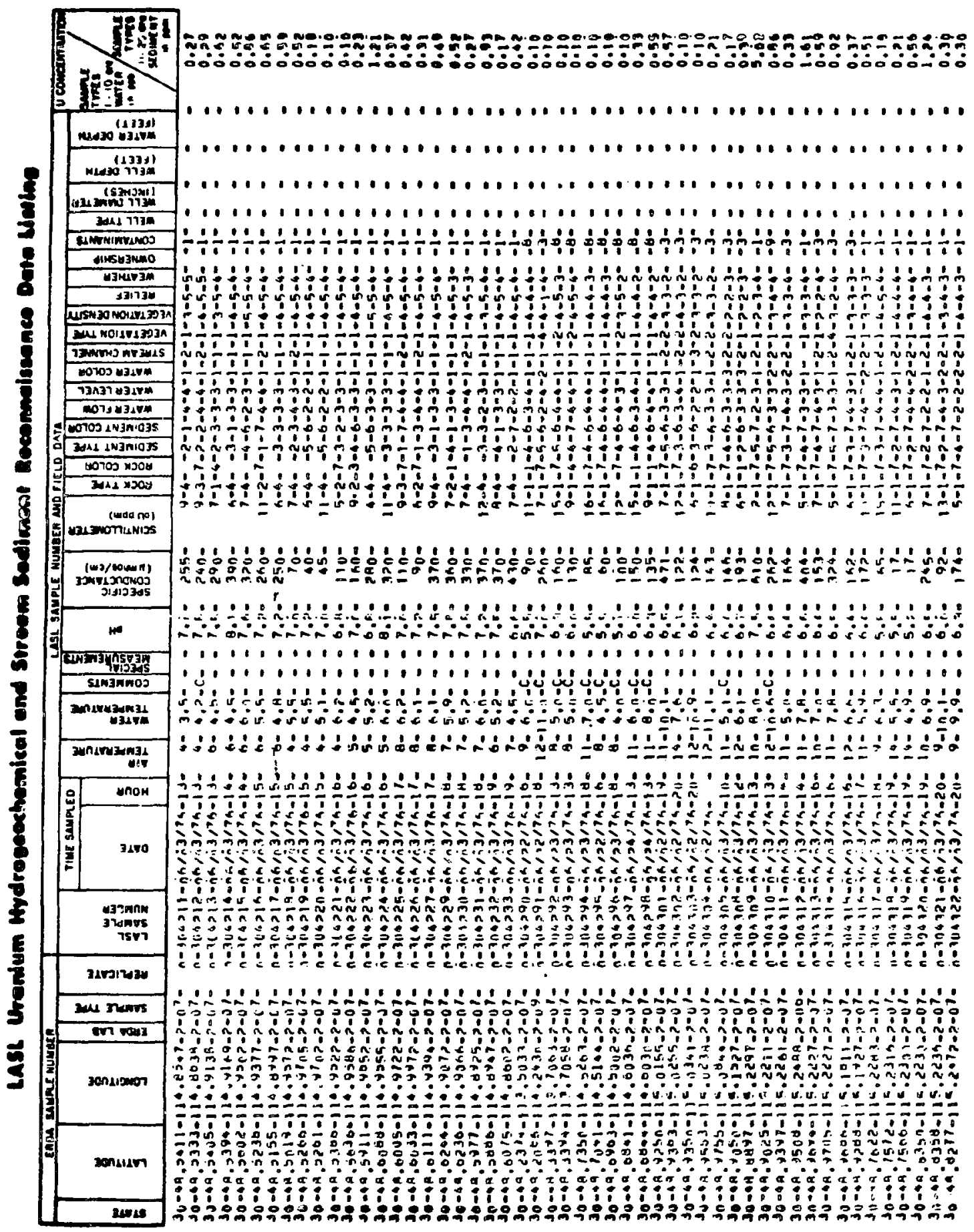




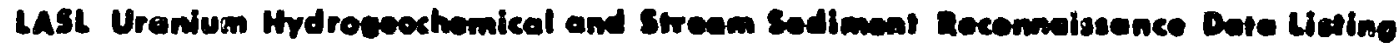

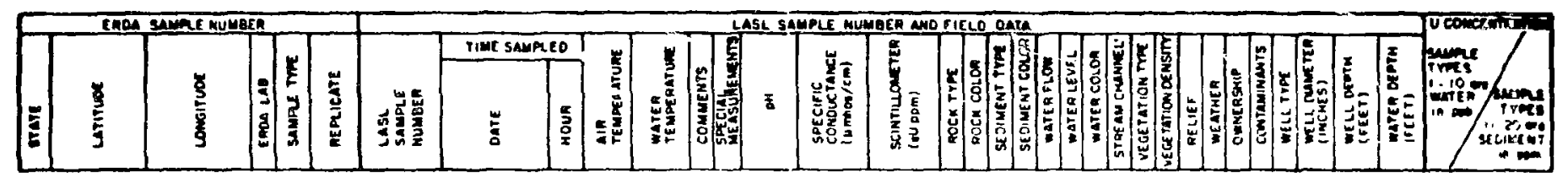

$70=0,0455-116,135,-2-21-$ Ju-49. $1027-115.2359=2-1)$ ?

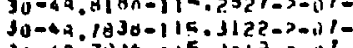

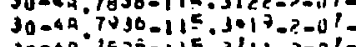
$33-4 a: 1525-115: 3 ! 11=-0-1=$

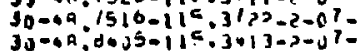

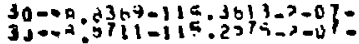
$30-49.970=115,302=-2-110$

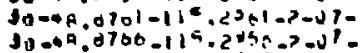

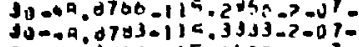
$30=08,7055-115,52537-57=$ $30-66,435,-115.7106->-20$ 30.49. +2? $1115.3325-2-07=$

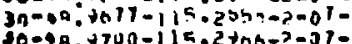

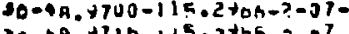

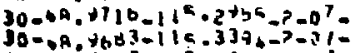

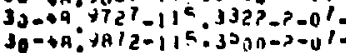

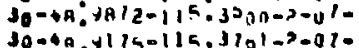

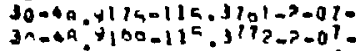
$37=0 ; y 01-11<: 41,3,5=31=$

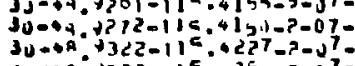

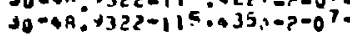

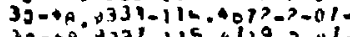

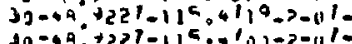

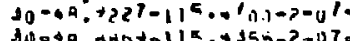

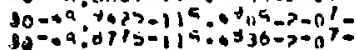

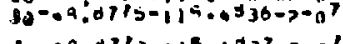

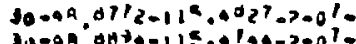

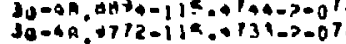

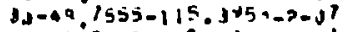

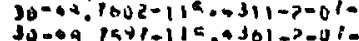
$30-6,1581+11<0,301-3-0,10$

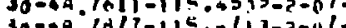

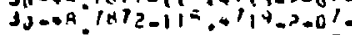
$30-40.1065-115: a 3 n \rightarrow \rightarrow \rightarrow+07=$

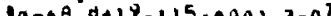
$30=40.000-115,3+0,0-0,0$

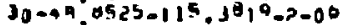

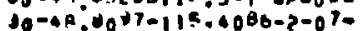

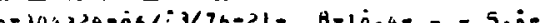

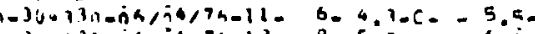

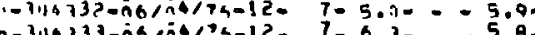

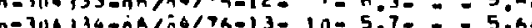

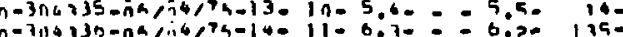

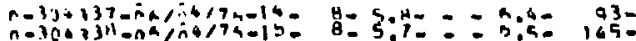

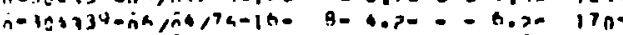

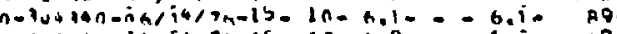

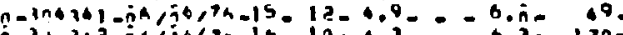
hal nala

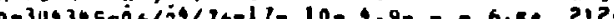

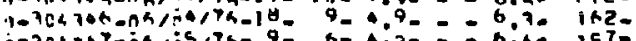

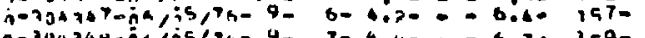

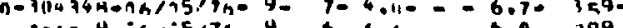

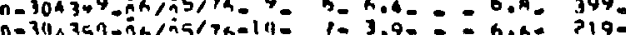

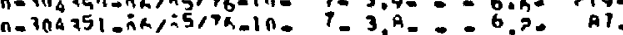

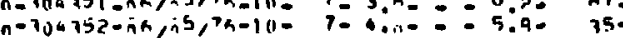

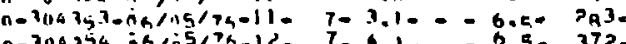

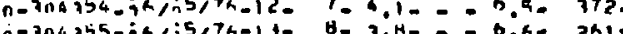
n-3na

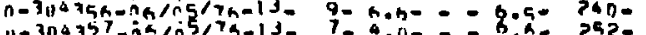

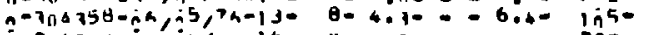

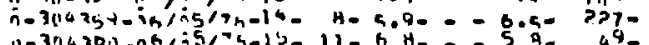

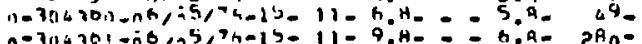

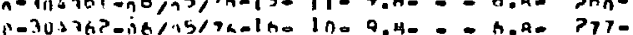

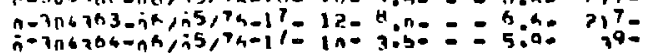

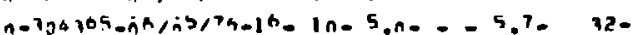
$n=3 n+36 h+n h / 10,1 h-15-15-A, 2-=-5,2-12-$

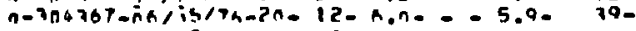

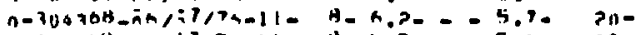

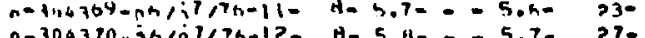

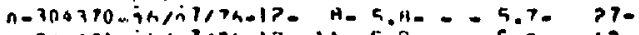

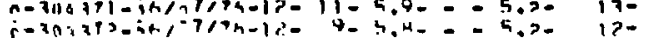

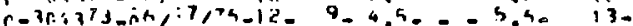

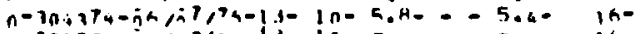

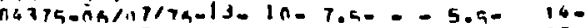

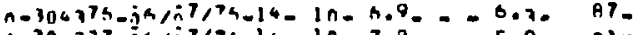
n-304377-16/i7/9h-14= $10=7.8==5.90$ s)

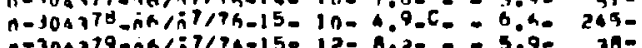

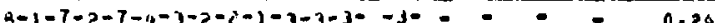

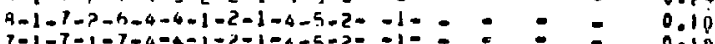
3010 $11-1-7-2-7-3-3-1-2-1-5-5-2=-1-0=0.96$ $14-1+7-1-1-3-3-1-2-1-5-5-3+-10=0.00$ $1>-1-7-1-1-4-4-2-2-1-9-5-3=-1=:=:=0: 10$

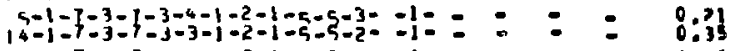
$1,1-1-7-3-1-4-4-1-2-1-4-5-2-1-1-00.96$ $4-1-7-3-7-3-3-1-2-1-5-5-2--1-0.10$

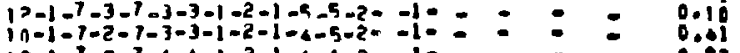
$1,-1-1-2-7-4+4-1+2-1-4-0-2--1-0=\div: 0.8$ $1 n-1-6-2-6-3-3-1-2-1-4-5-3--10=0=0.30$

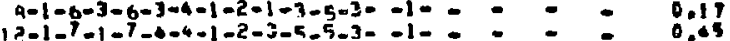

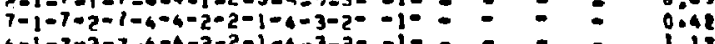
$4-1-7-7-7-4-4-2-2-1-4-3-2--1-\div= \pm=1.17$

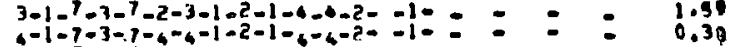

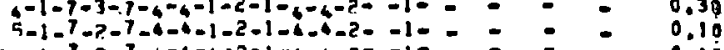

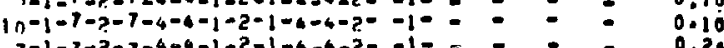
$4-1-7-3-7-4-3-1+2-1-4-4-2--1-\div=0 ; 0.40$

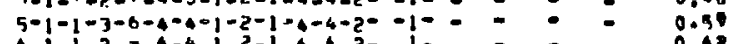

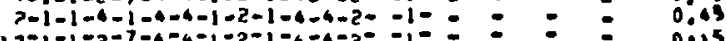

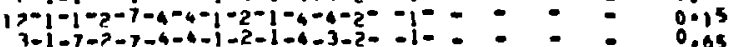
$a^{2}+1-7-2-7-4-4-1-2-4-4-1-2--1==0=0.10$

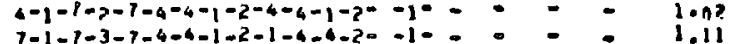

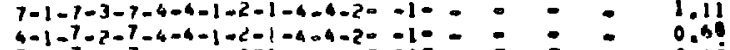
0.18

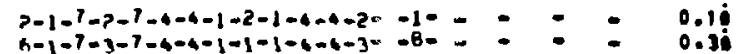

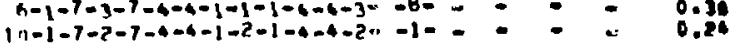
$14-1-7-3-6-3-4-1-2-1-6-5-3--1-=-0=0.43$ $11-1-1-3-7-2-5-1-2-1-a-5-3-10=0.41$

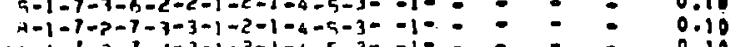
$11-1-2-1-1-3-1-2-1-4-5-3-1=0=0.10$ $14-1-7-2-7-3-6-1-2-1-7-5-3--1-=0 \quad 0.10$ $17-1-5-2-5-3-3-1-2-1-4-5-3-1-1=\div \quad=0.35$ $11-1-6-3-6-3-3-1--1-7-5-3--1=:=\leq: 0.30$ 


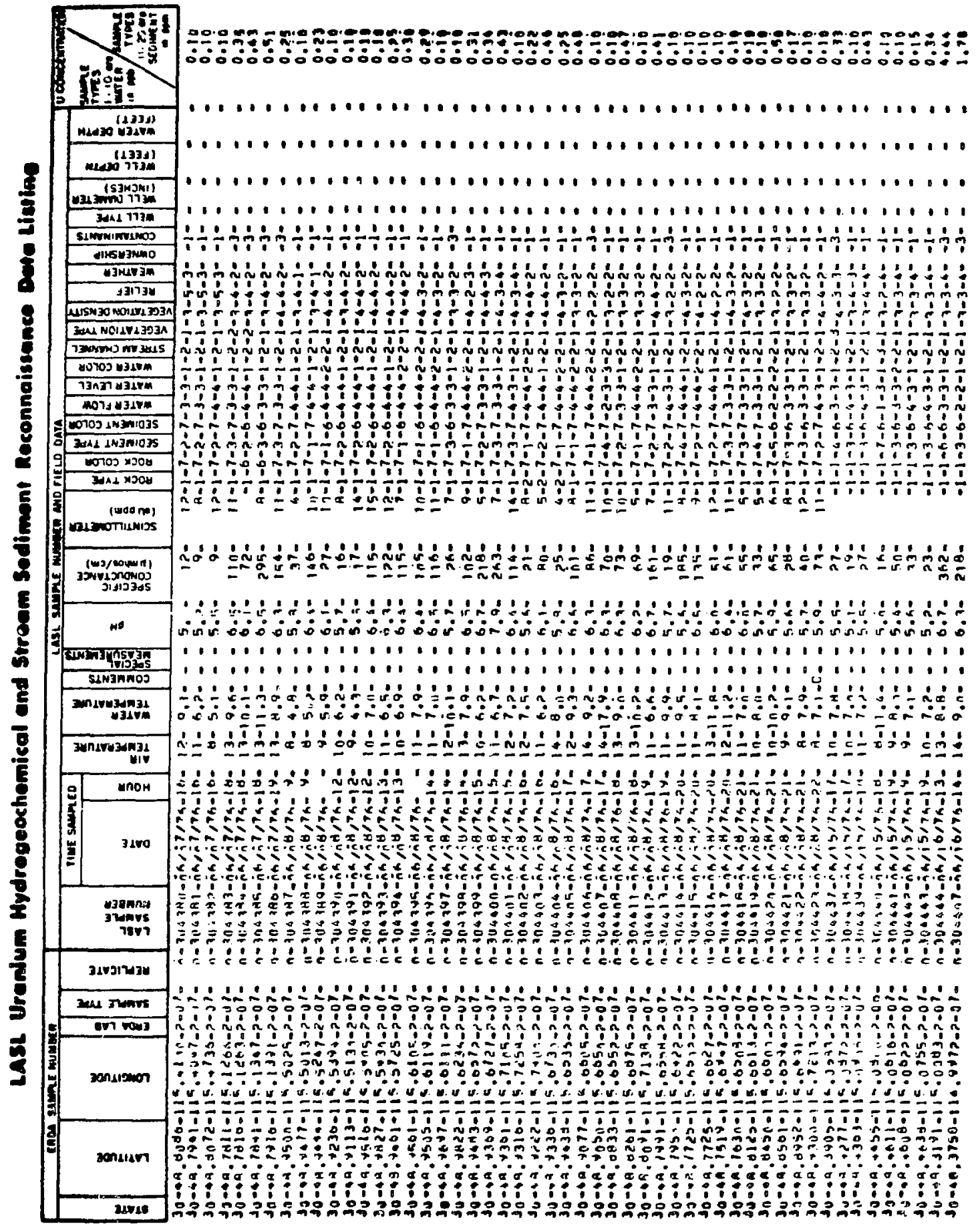




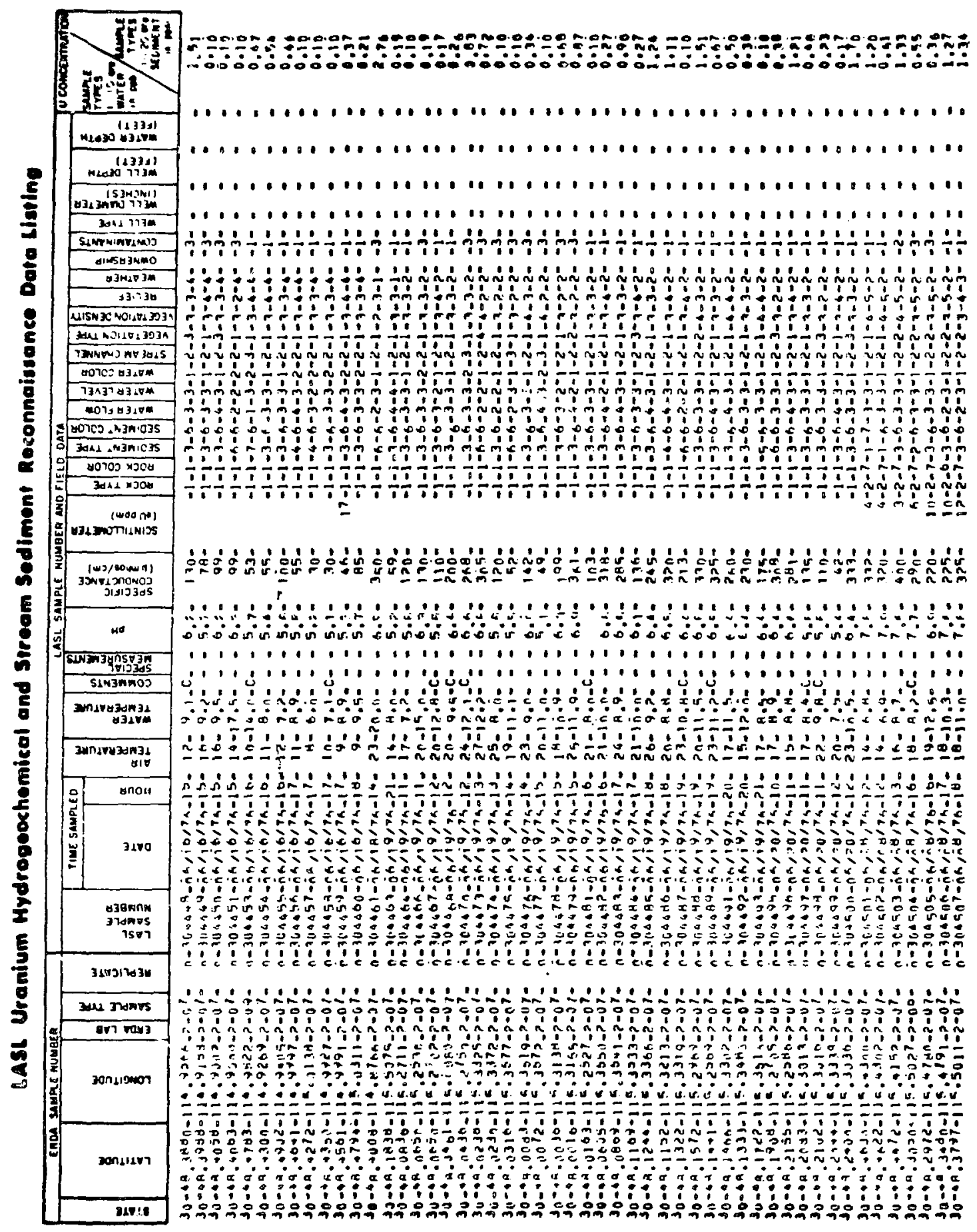




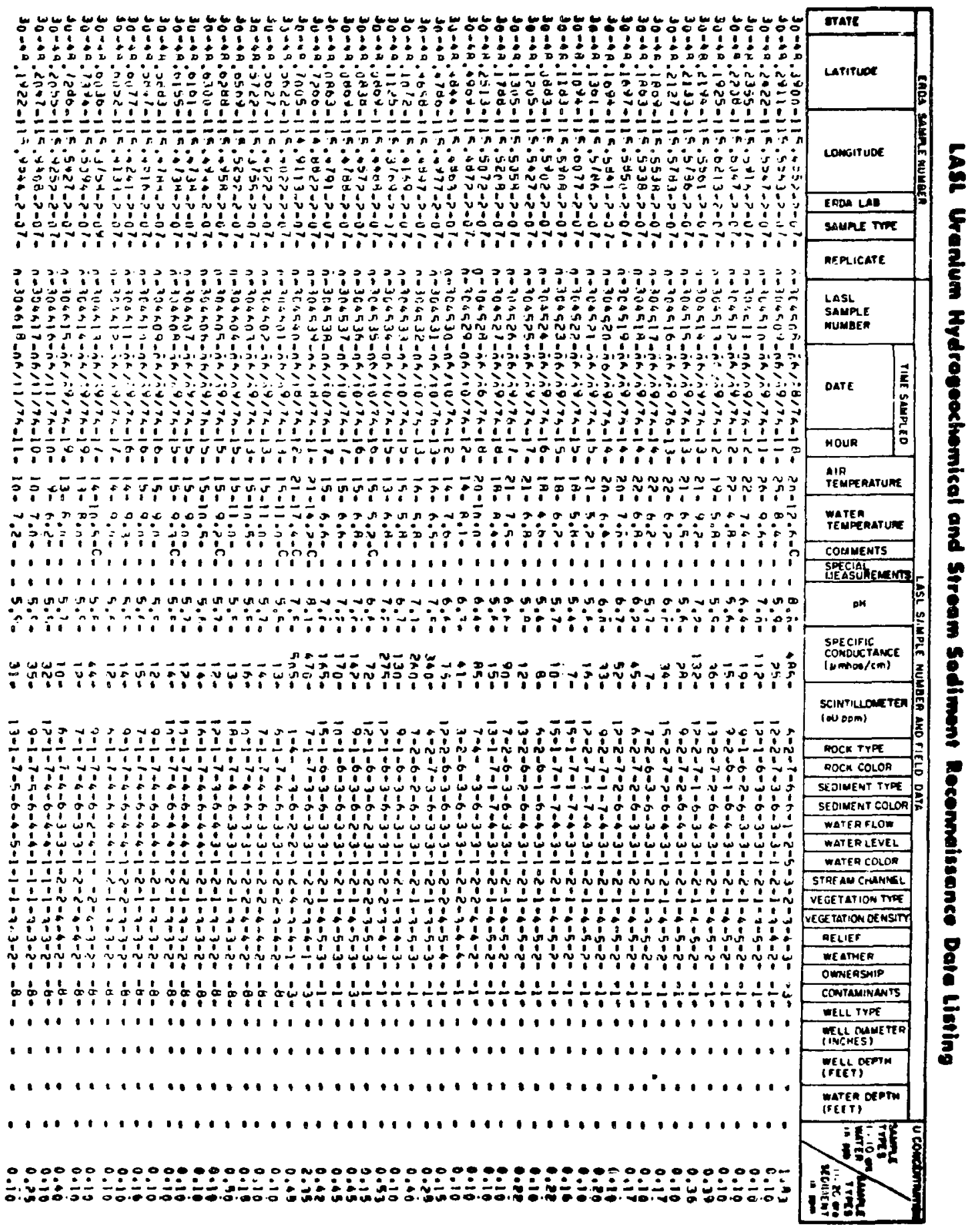




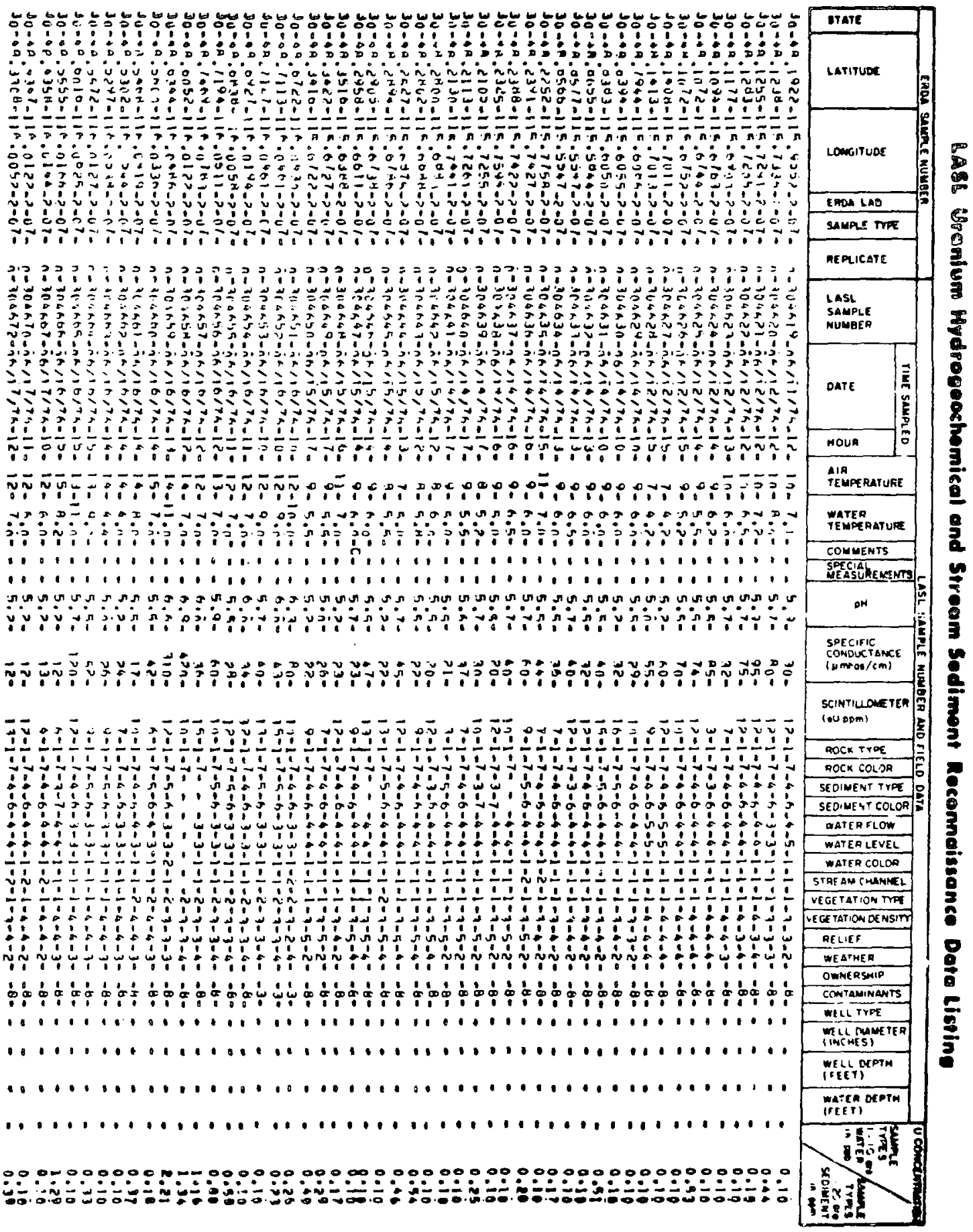




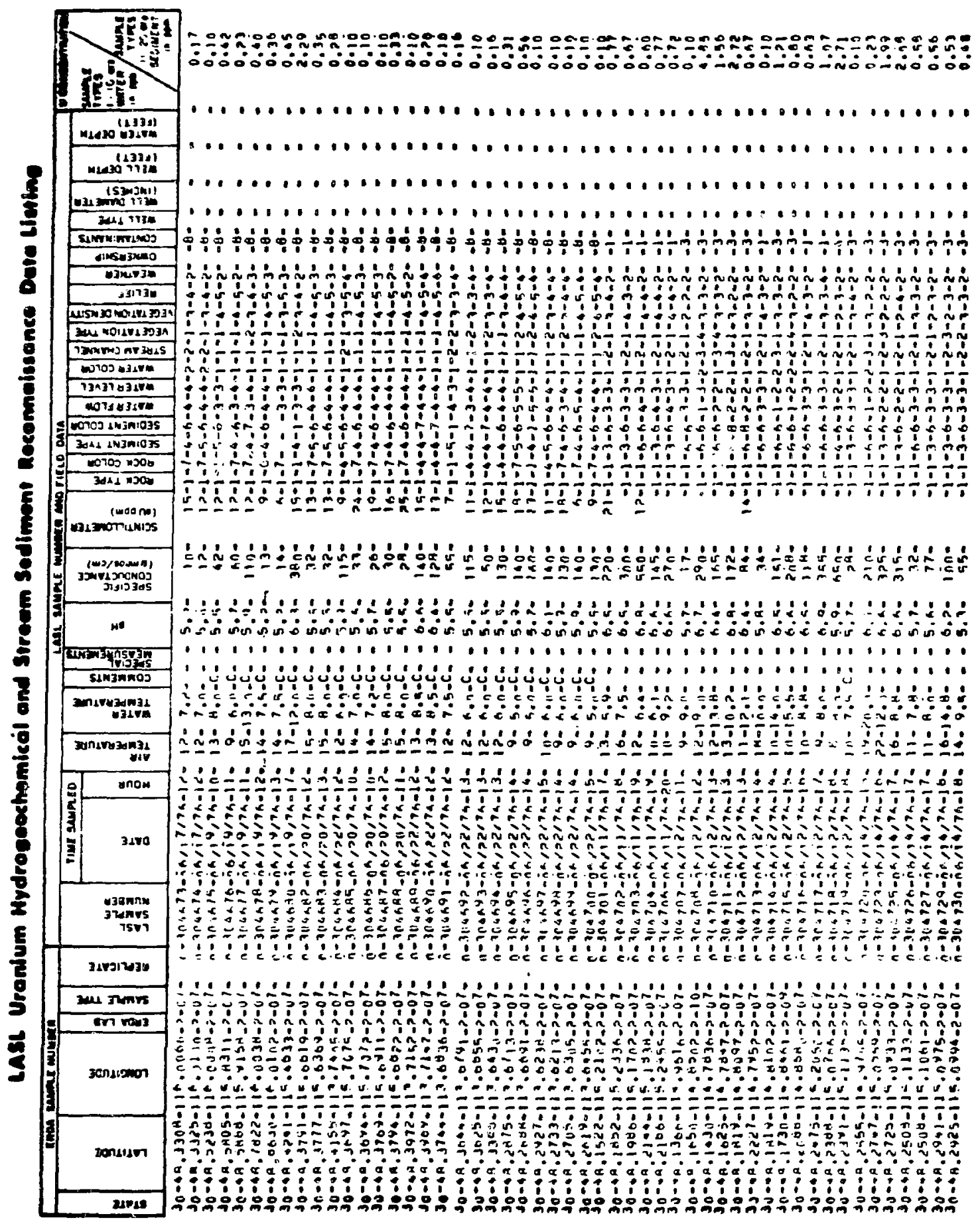




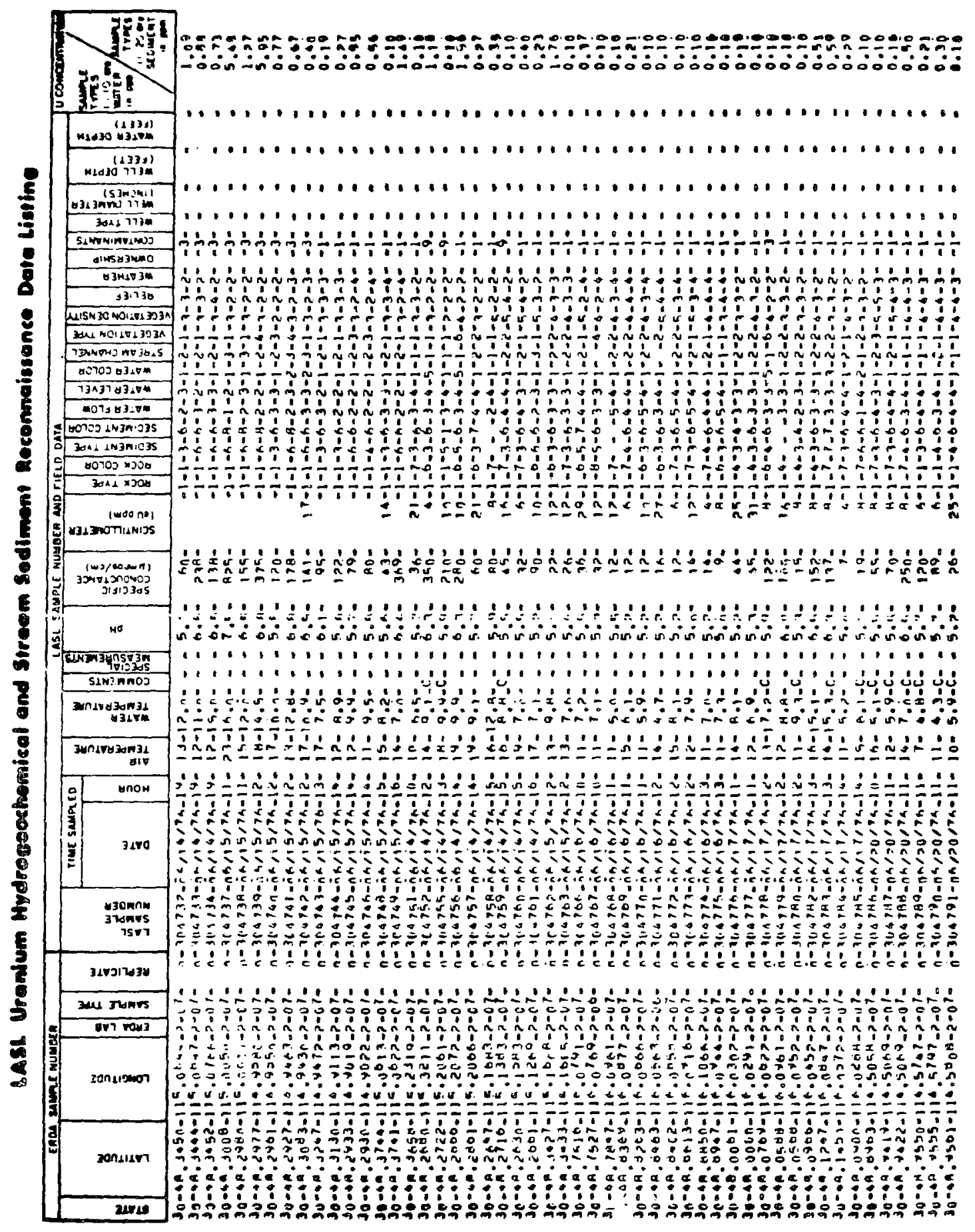




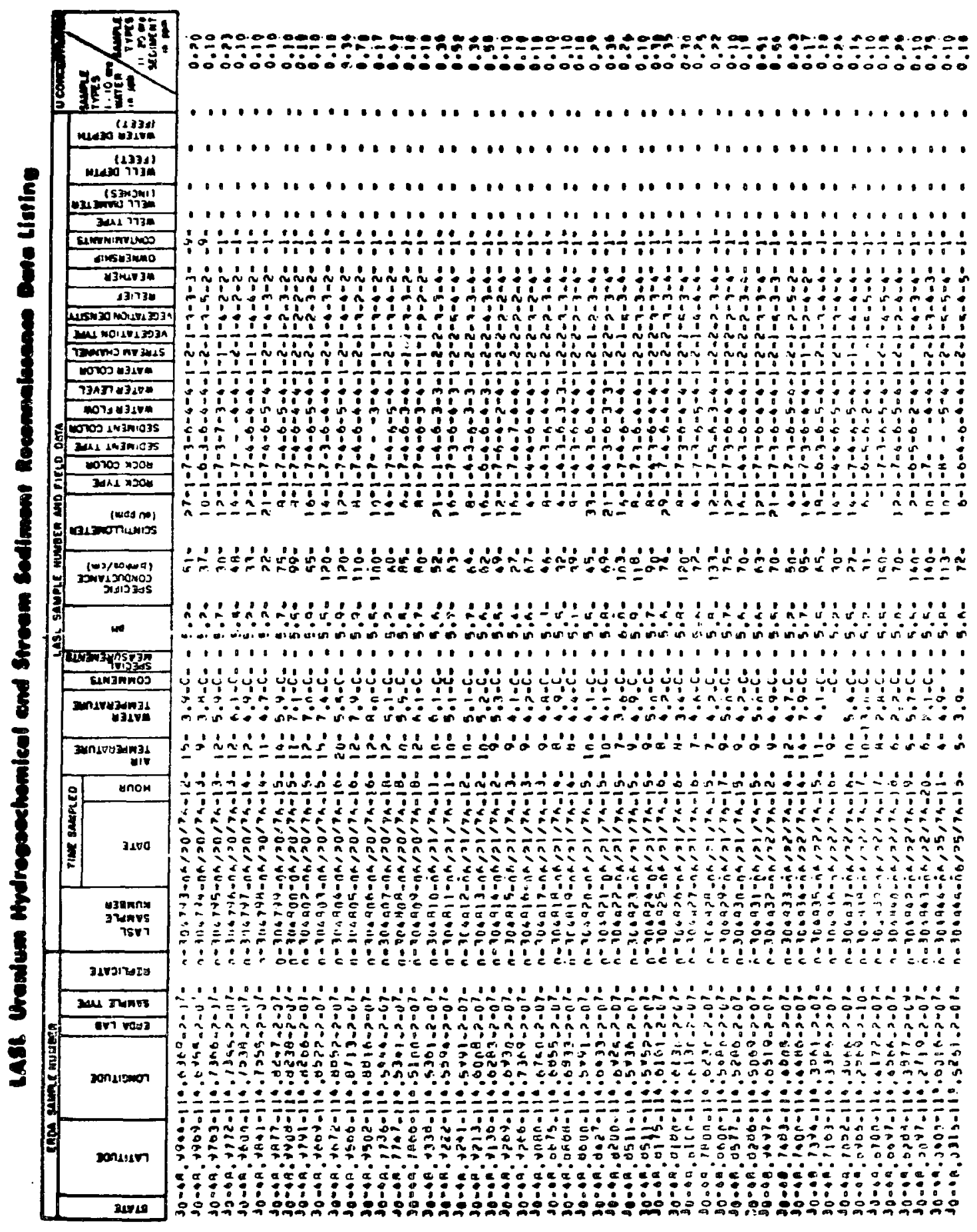




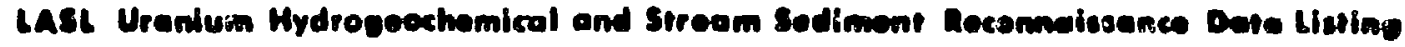

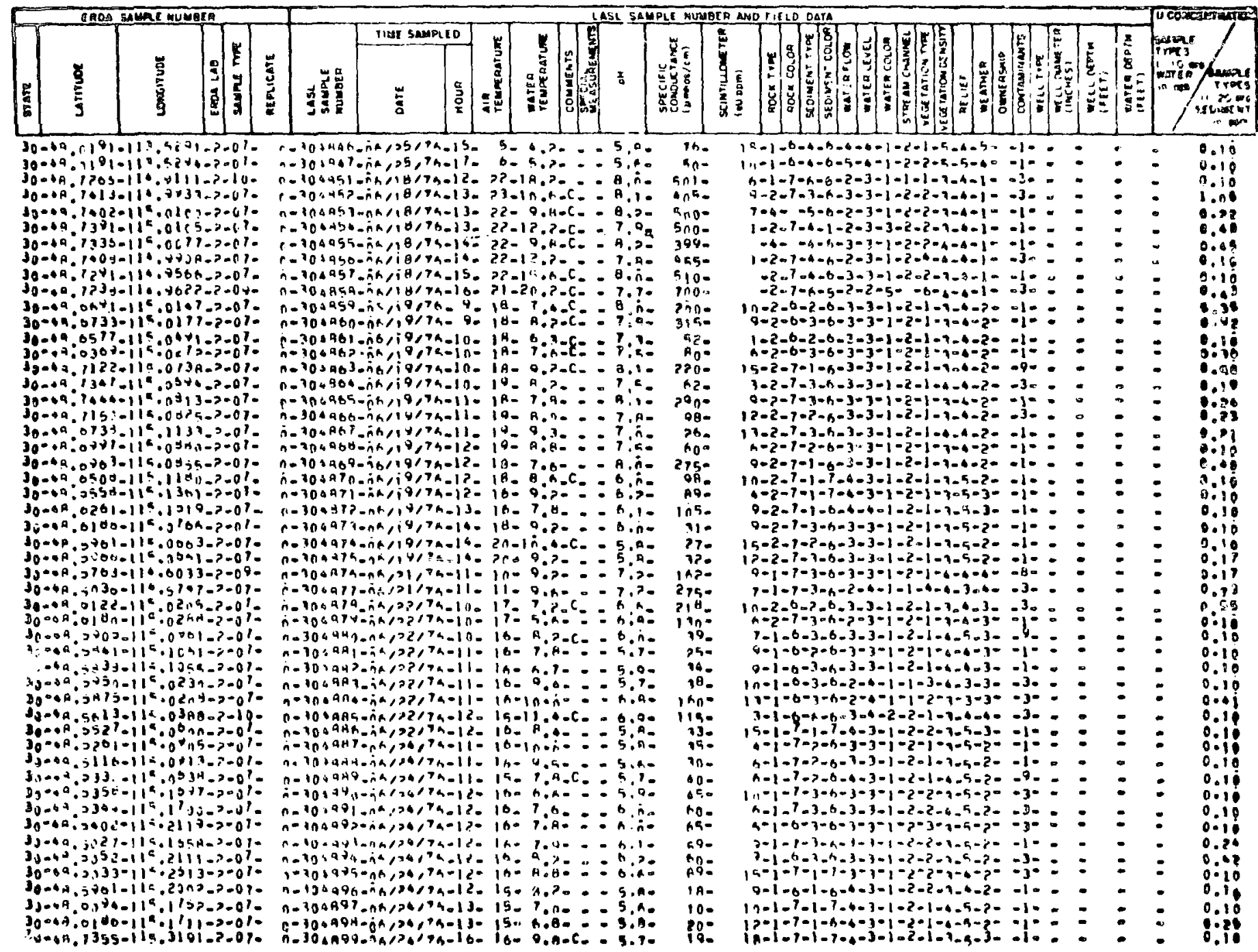




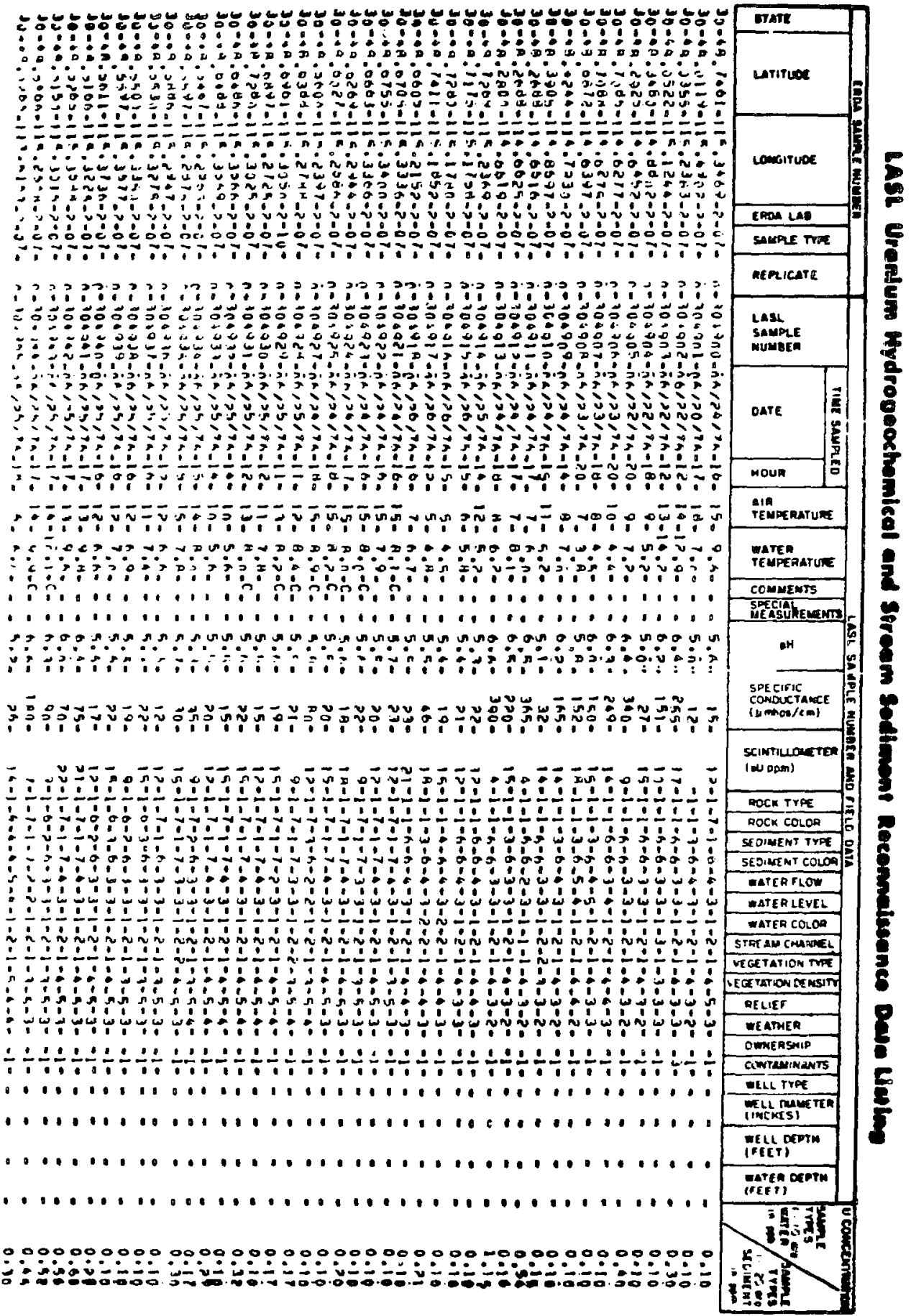


APPENDIX C-II

WATER SAMPLES ANALYZED BY DELAYED-NEUTRON COUNTING

(PAGE C-36) 


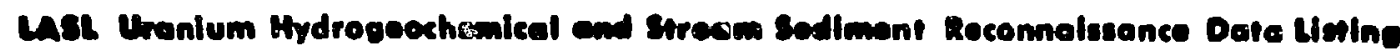

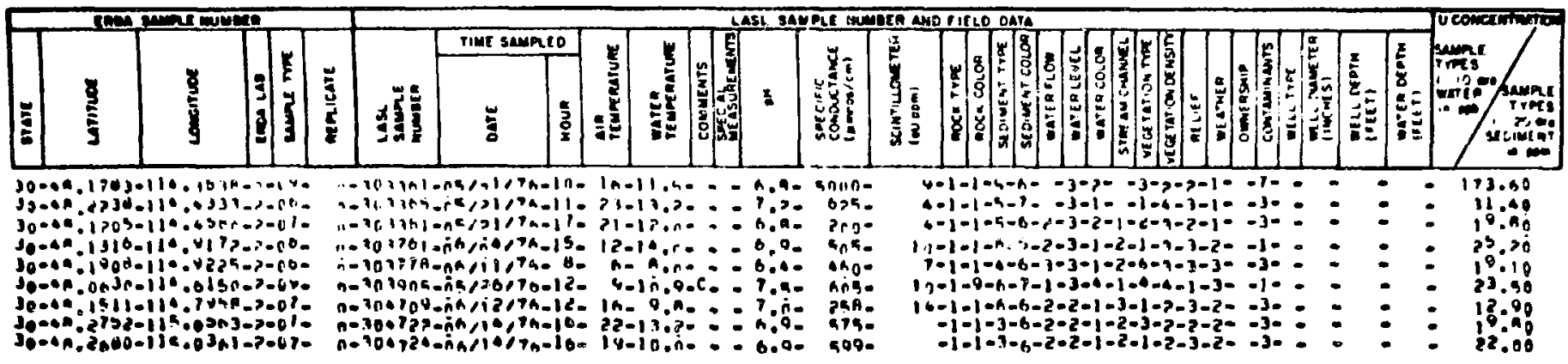


APPENDIX D

LISTINGS OF FIELD DATA AND URANIUM CONCENTRATIONS

FOR

SEDIMENT SAMPLES

SIEVED TO -100 MESH

FROM

LINCOLN AND FLATHEAD COUNTIES, NORTHWEST MONTANA

SAMPLES ANALYZED BY DELAYED-NEUTRON COUNTING

(PAGES D-2 THROUGH D-35)

(See Appendix E for codes to listings) 


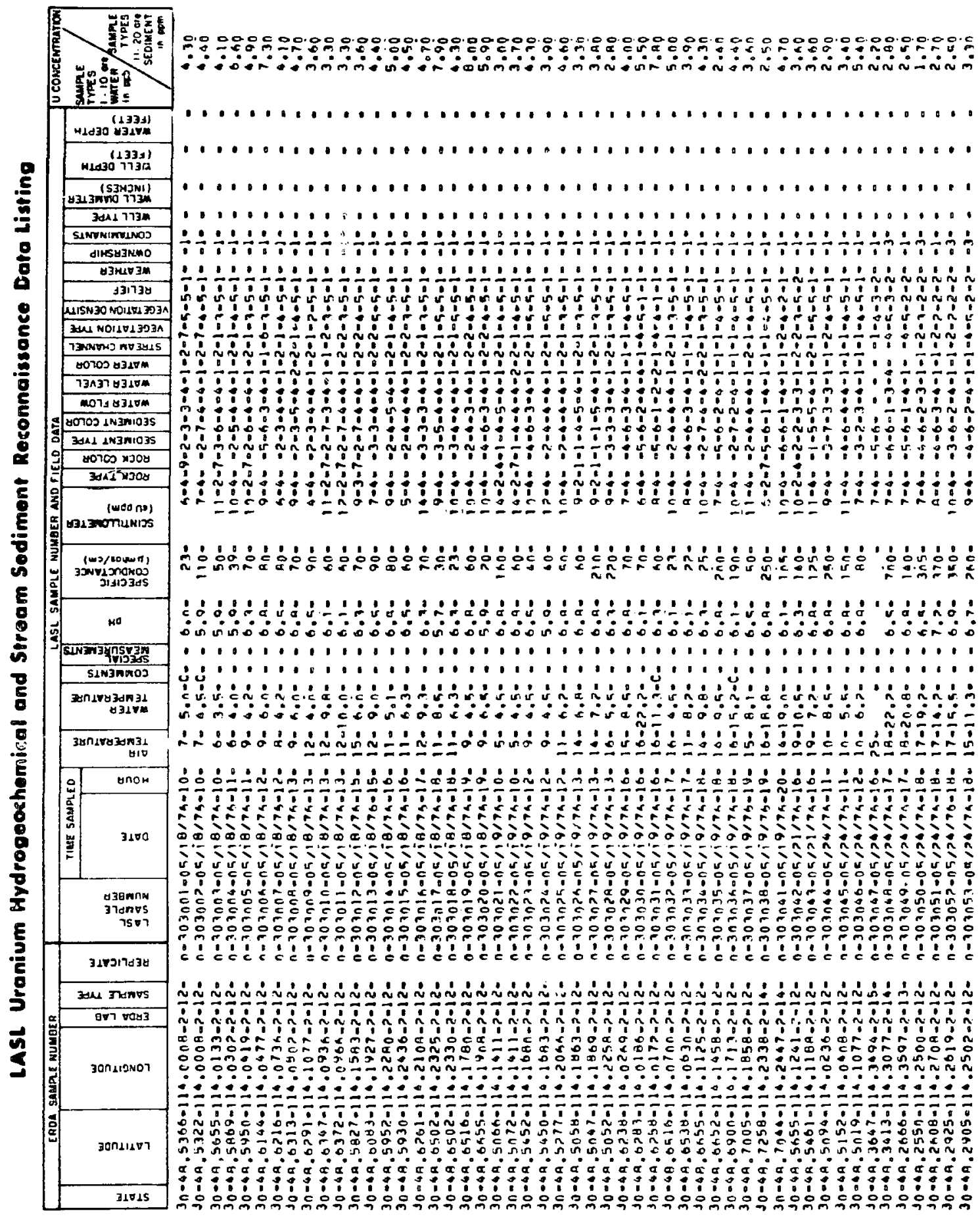




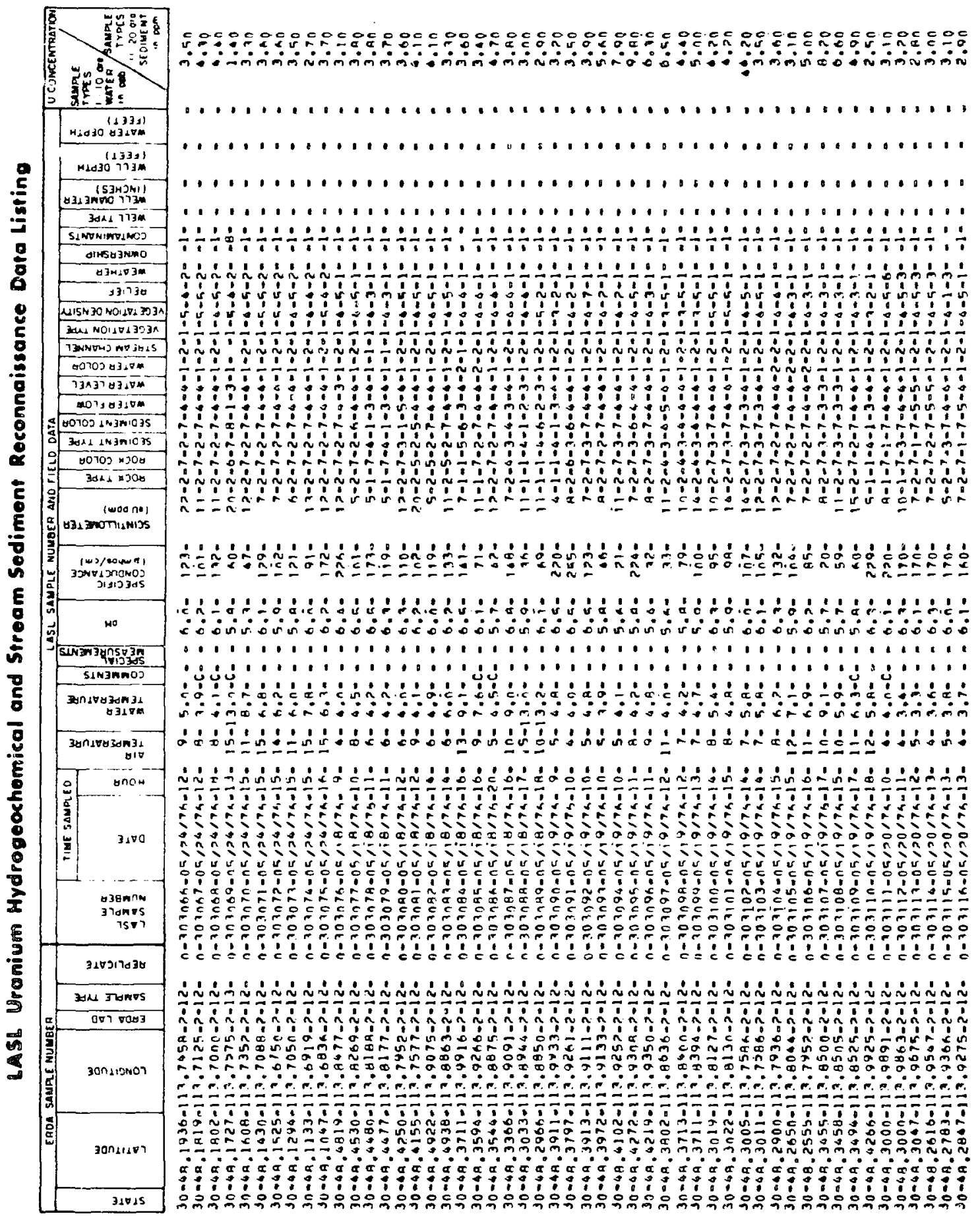




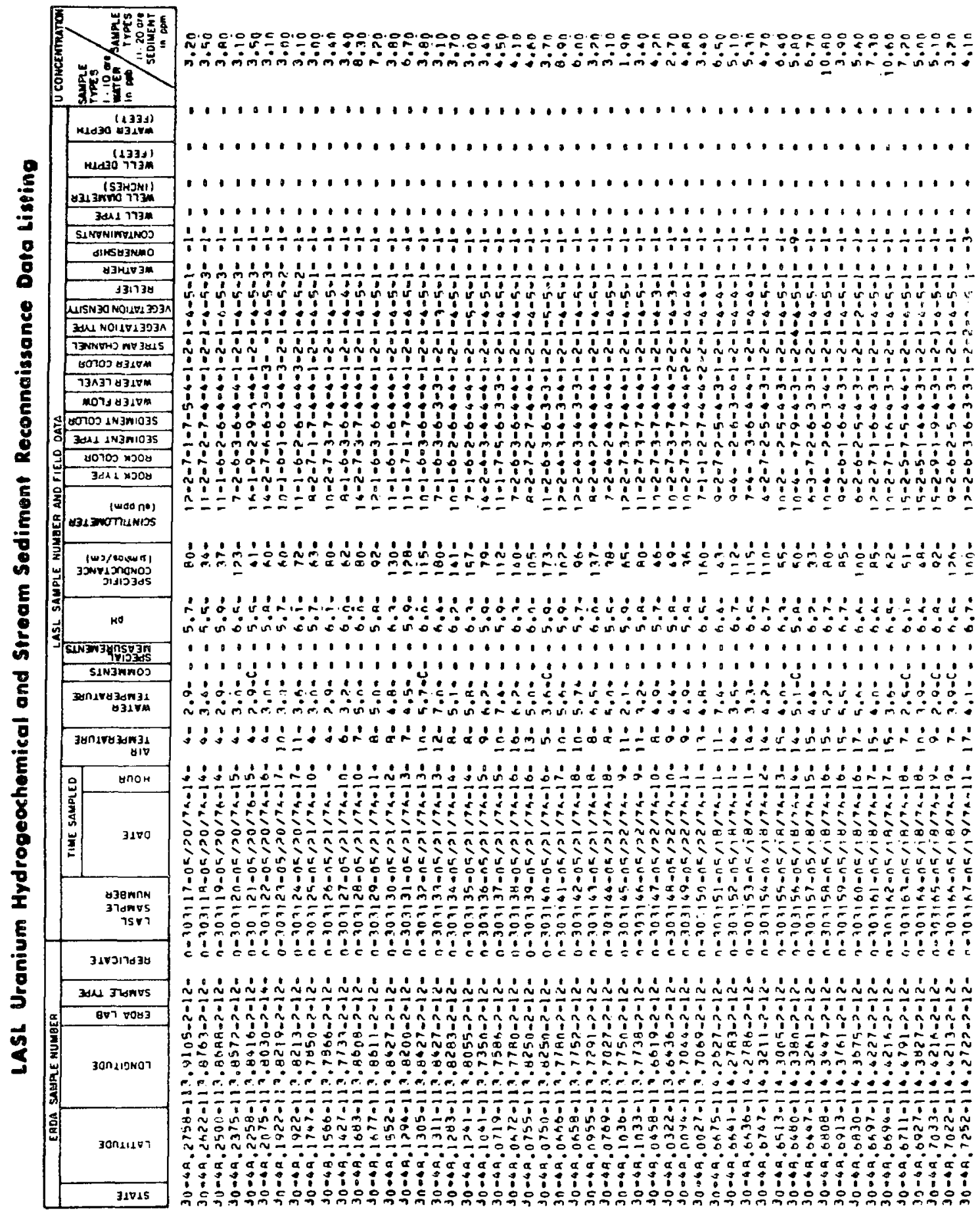




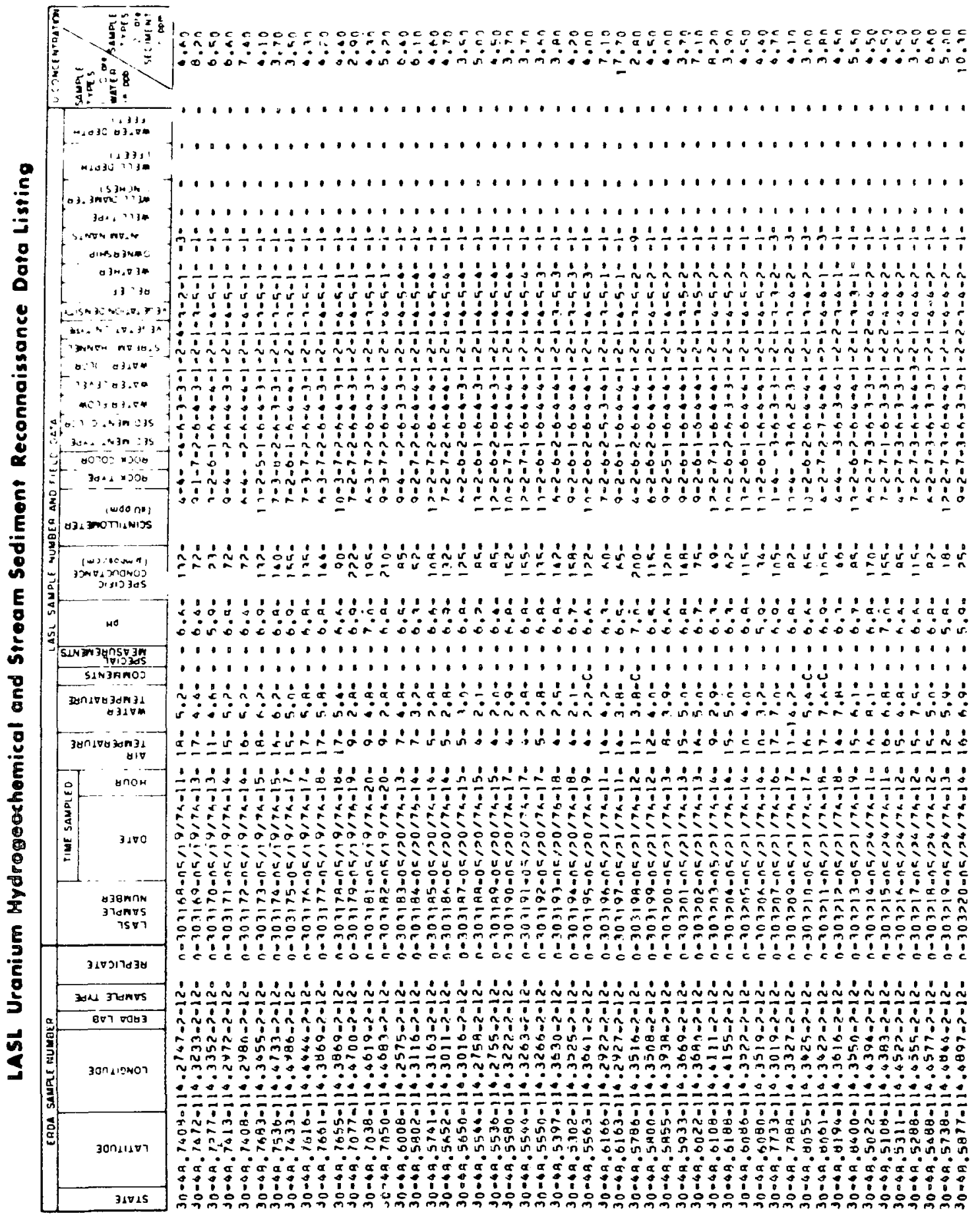




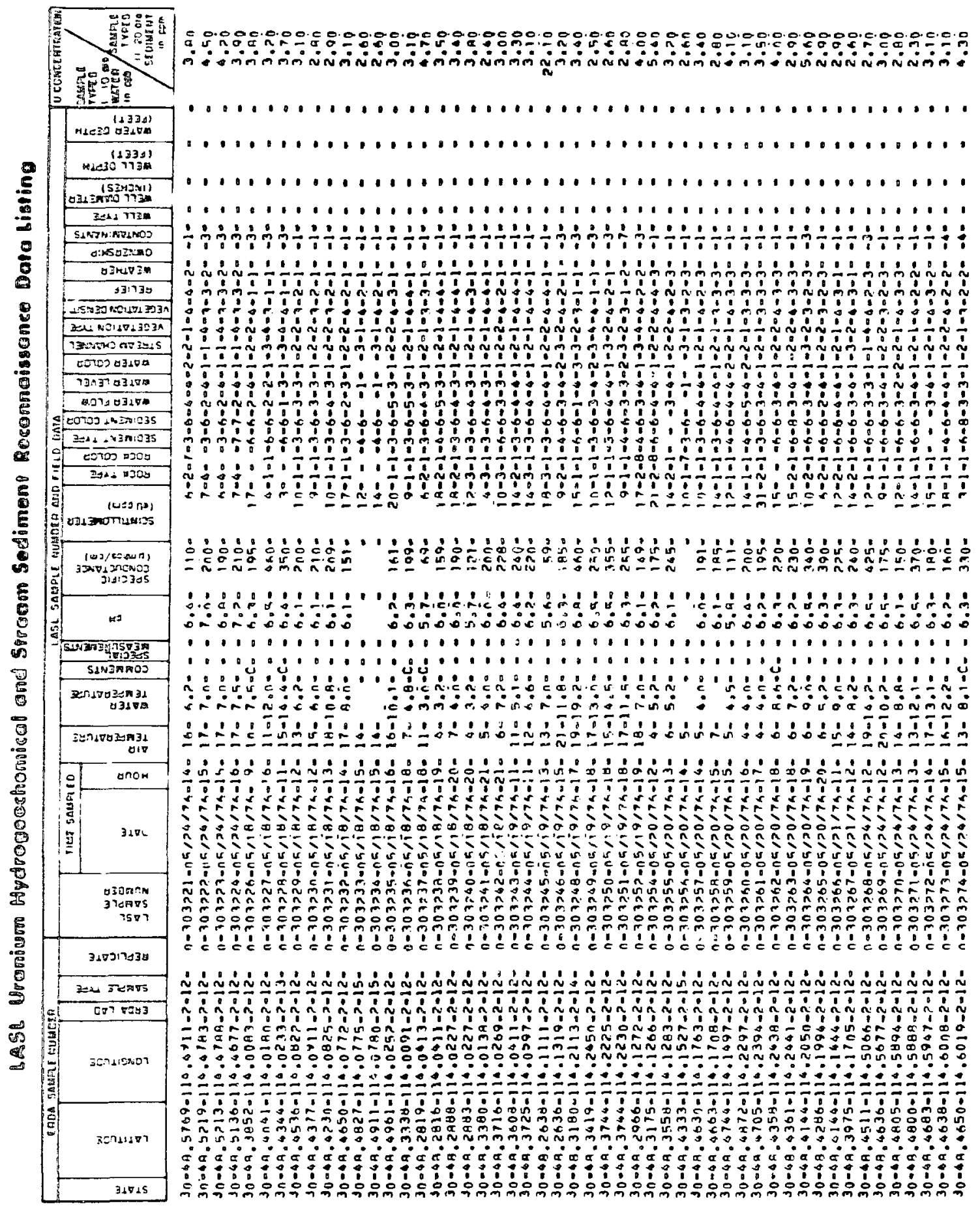




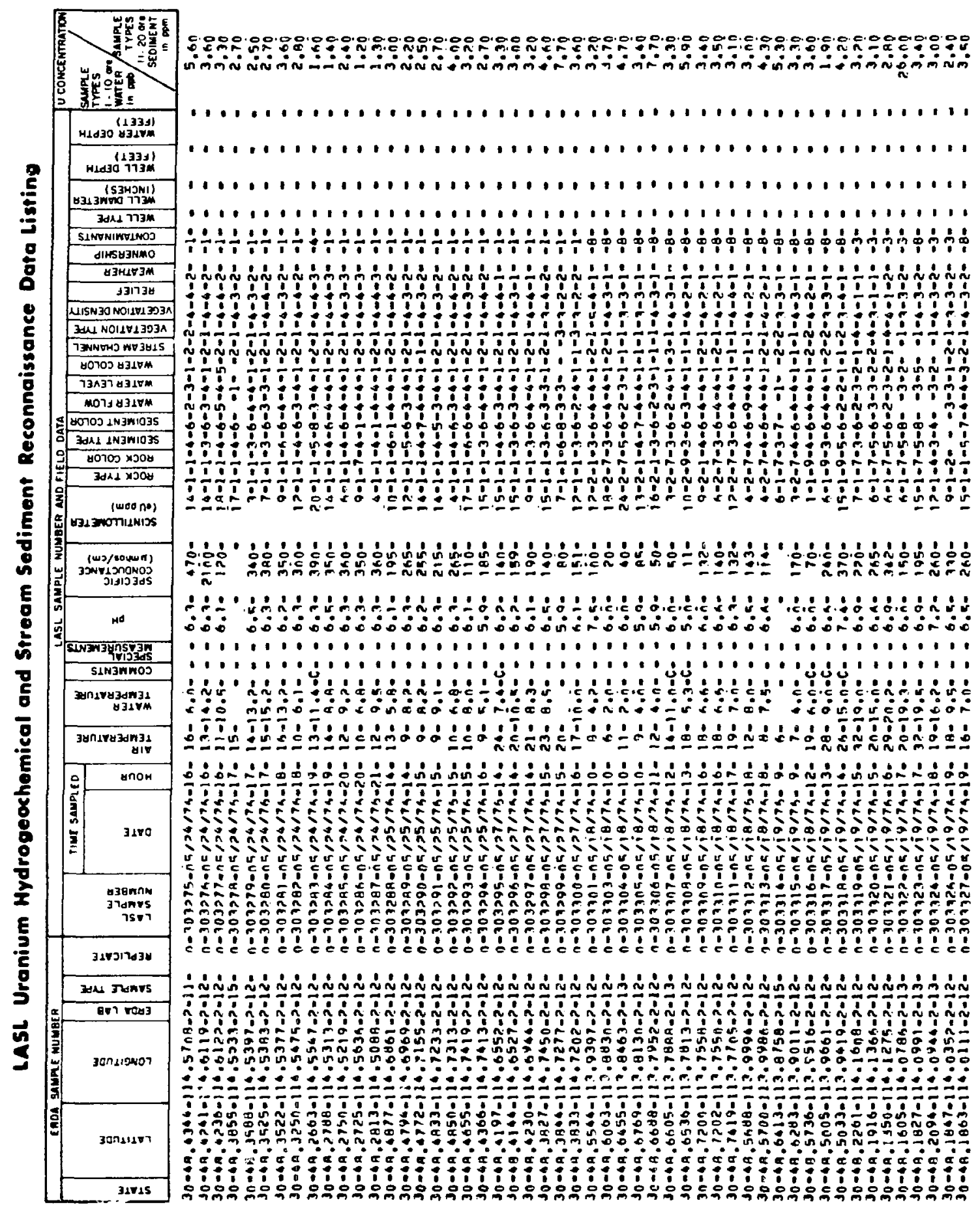




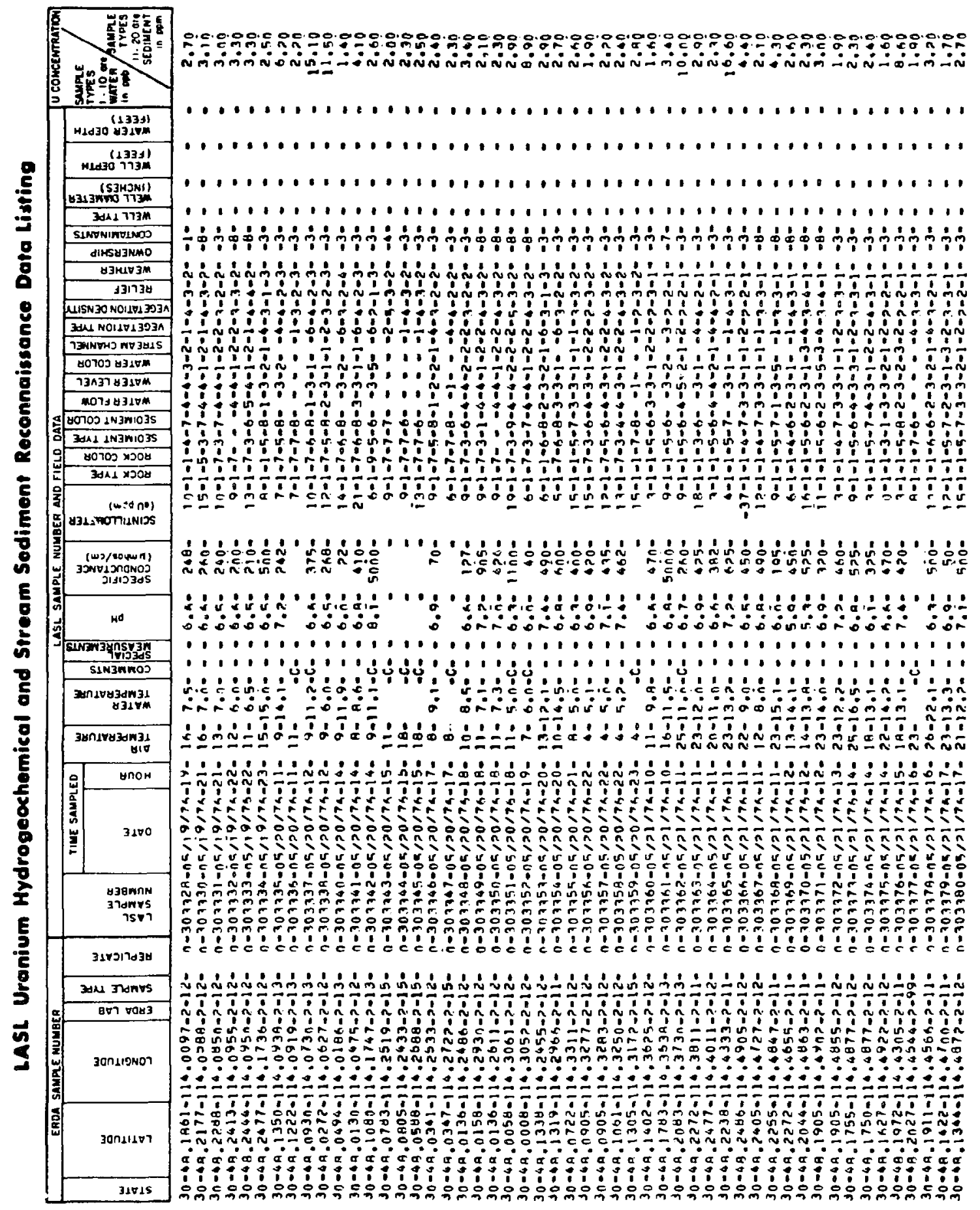




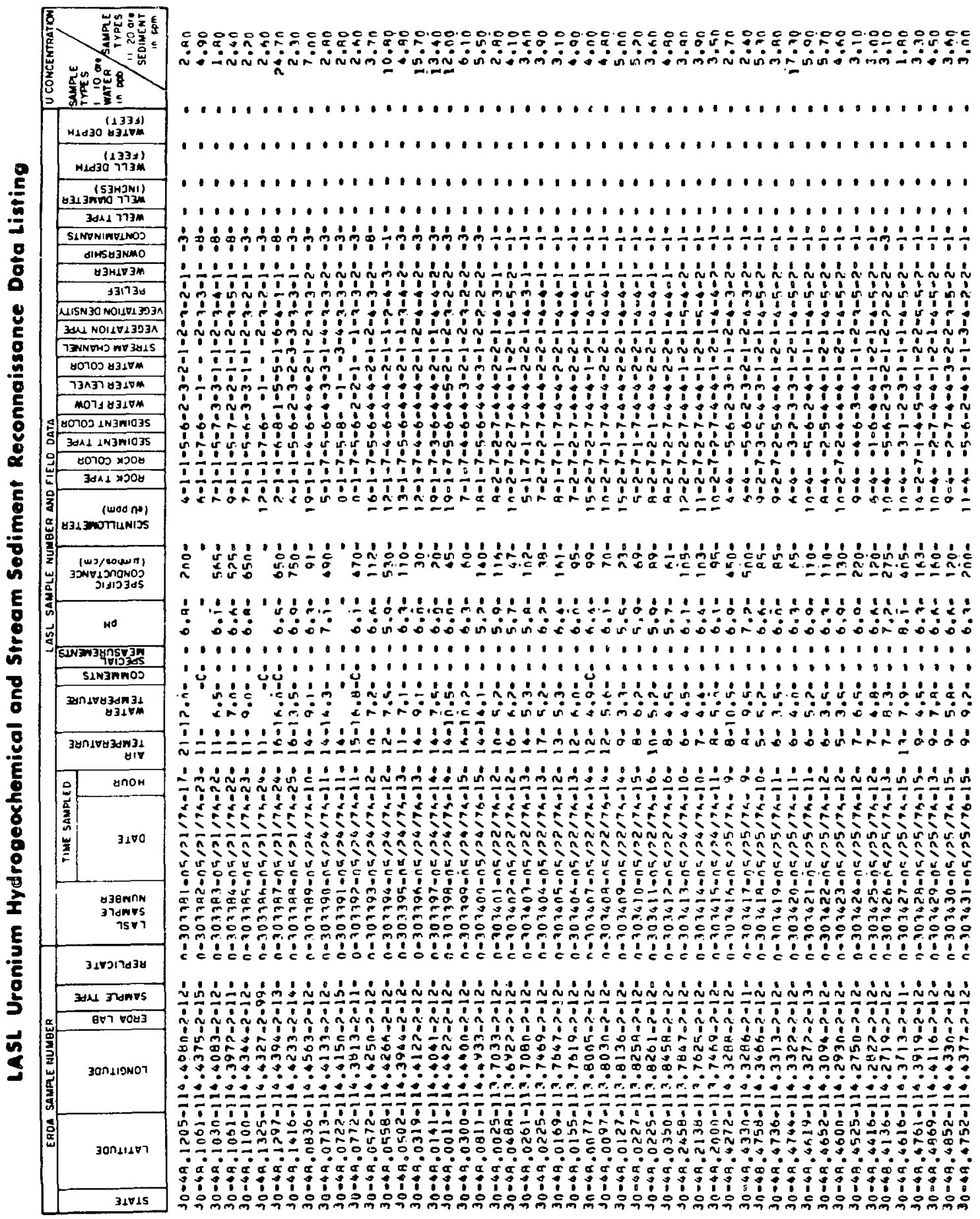




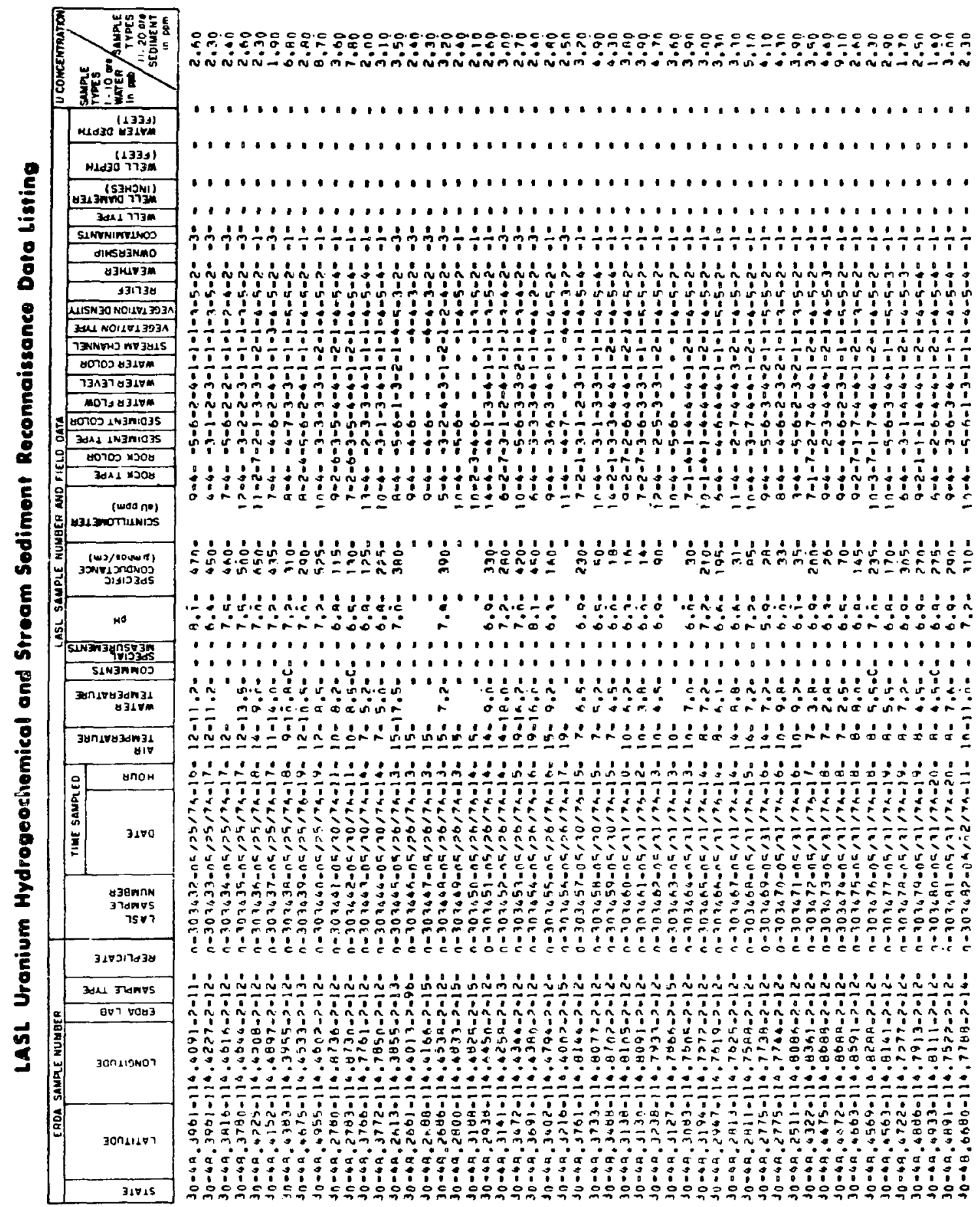




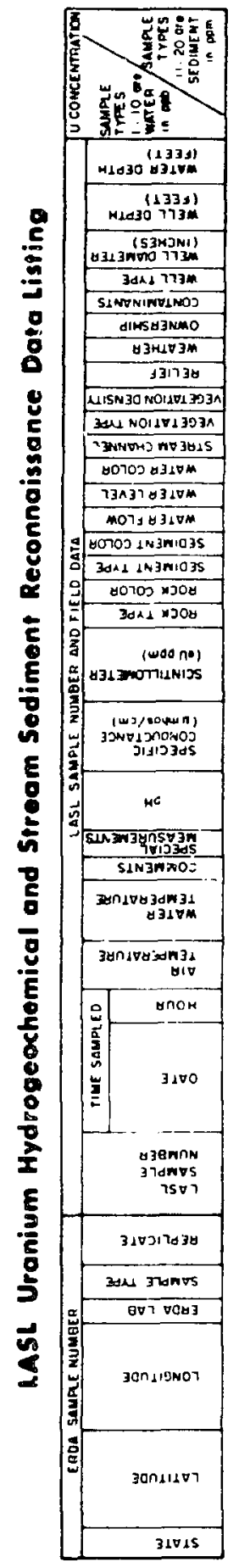

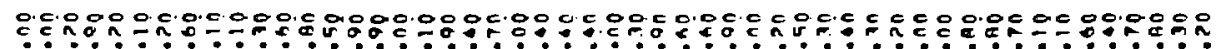
mom-iñ

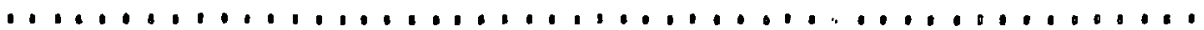

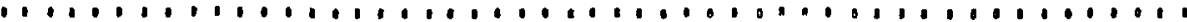

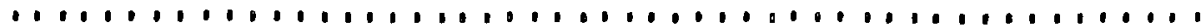

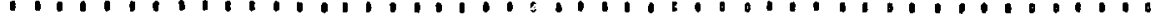
ำำคั

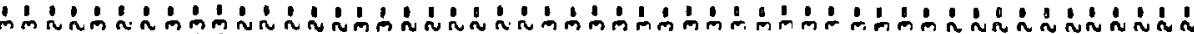

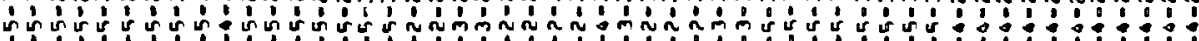

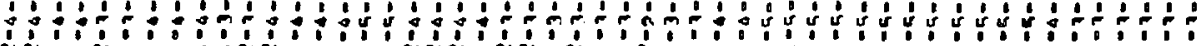

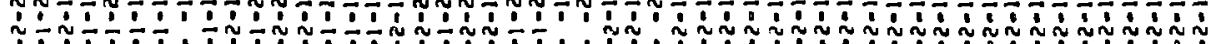

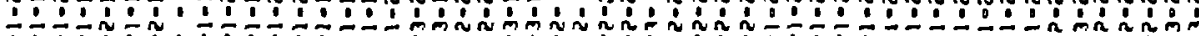

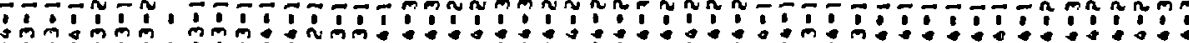

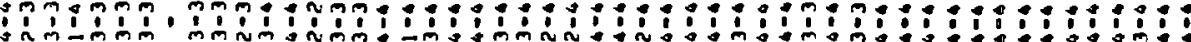

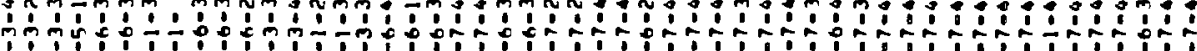
คำ

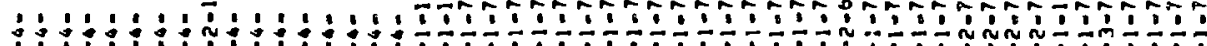

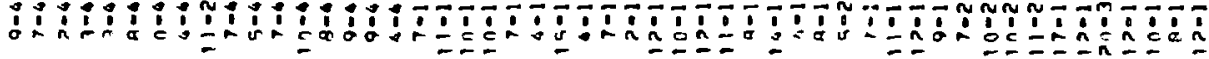

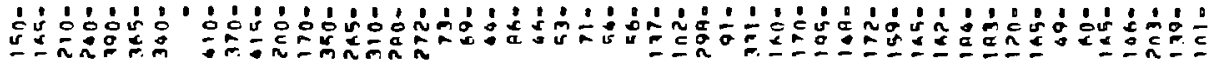

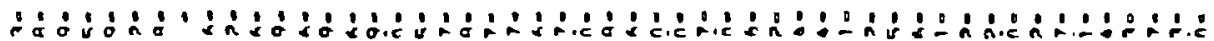

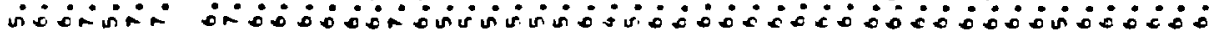

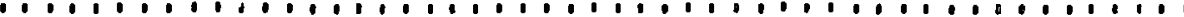

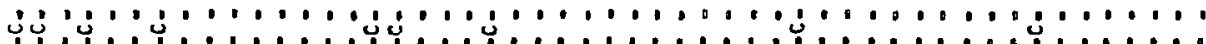

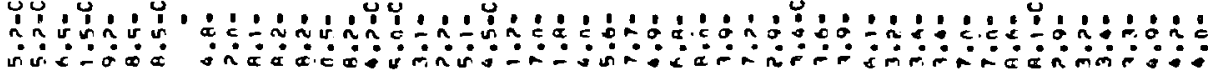

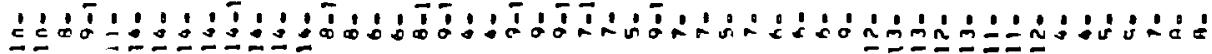

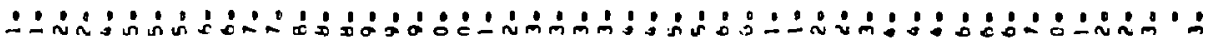

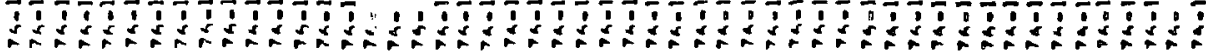

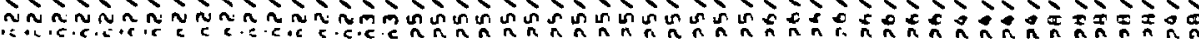

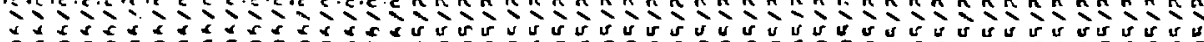

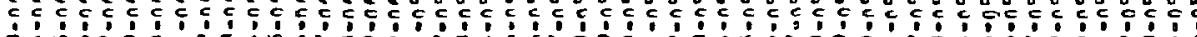

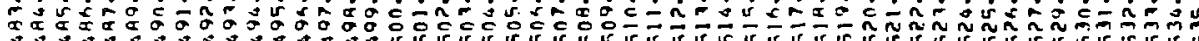

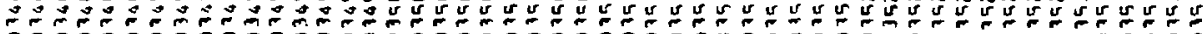

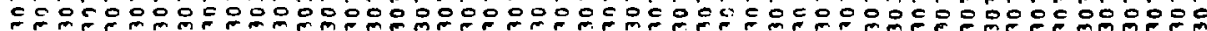

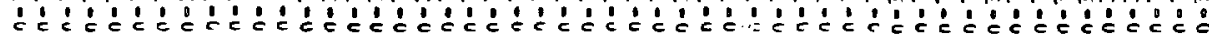

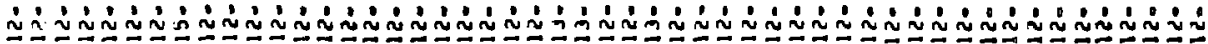

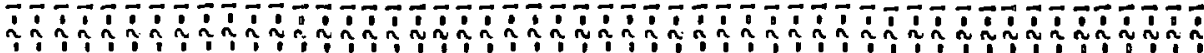

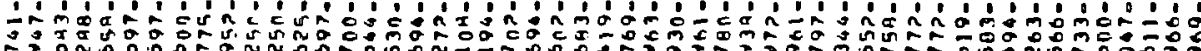

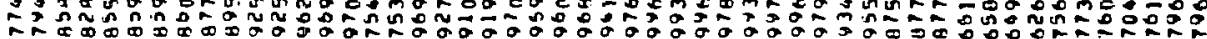

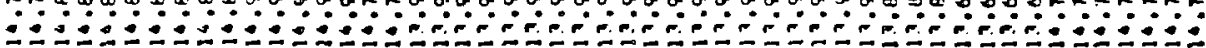

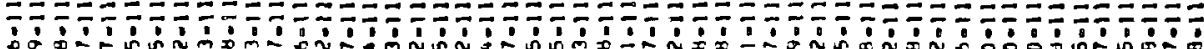

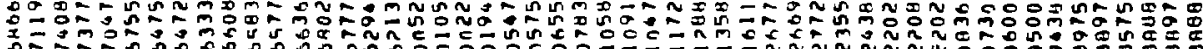

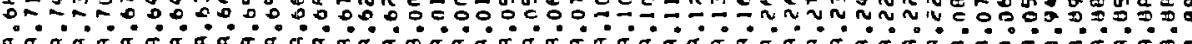

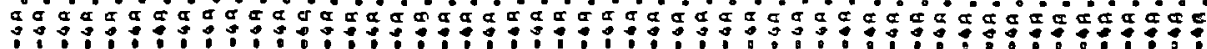

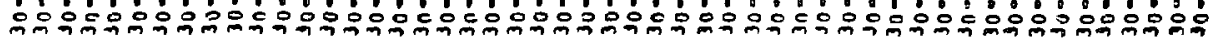




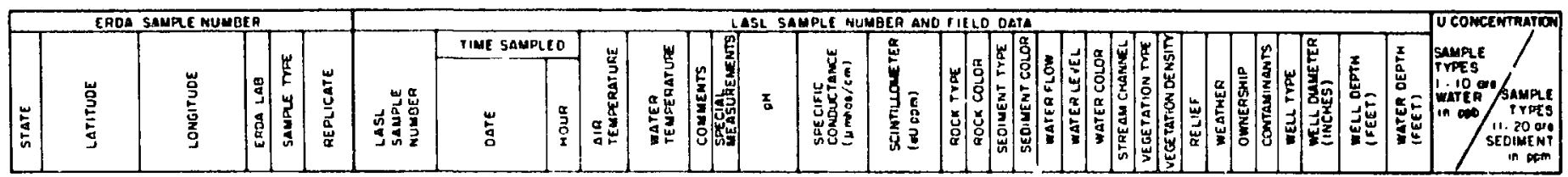

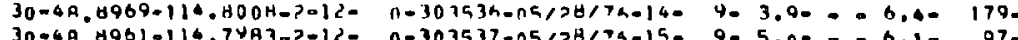

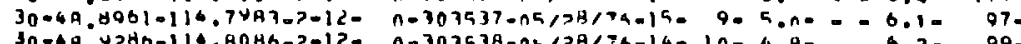

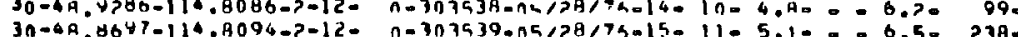

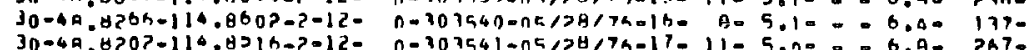
$10-4 A .830 n-114.8405-2-12-$

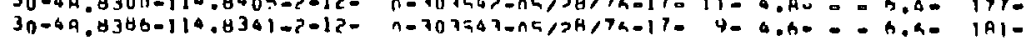

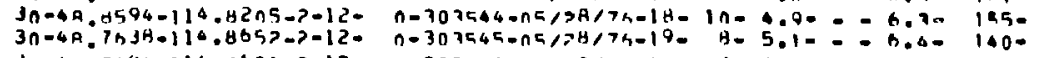

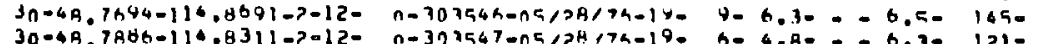

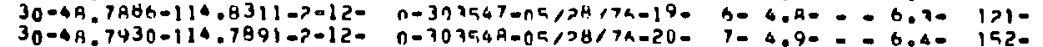

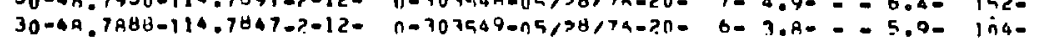
$30-09.7977-114.760 n-7-12-0-20355 n-n 5 / 3817 A-20-5=4.5=\ldots-6.1-75-$

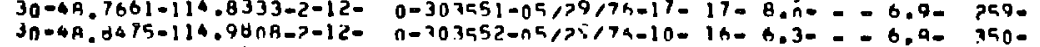

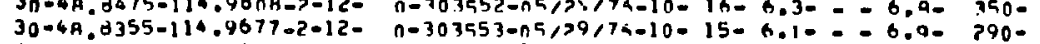

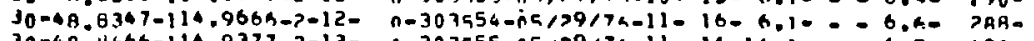

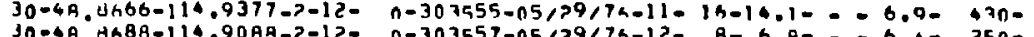

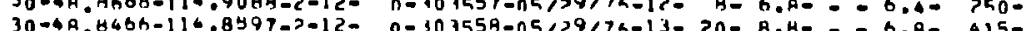

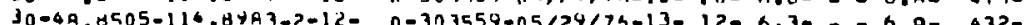

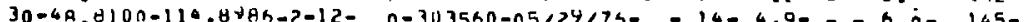

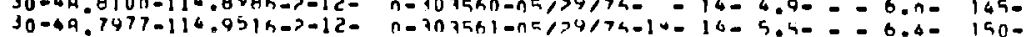
30-4a.1977-114.4527-P-12- n-3n3567-na/79/74-16-12-9.3- - - 6.90 7i5$30-4 R .190 n-114.9794-2-12-n-203567+n 5 / 39 / 7 h-15-16-9 . H-\ldots=0.9-550-$

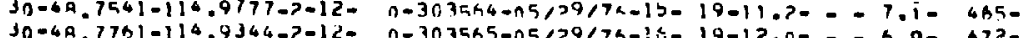

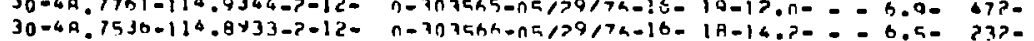

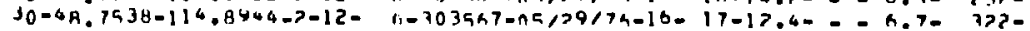

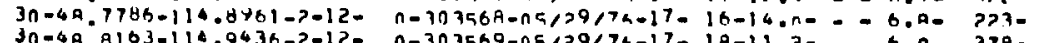

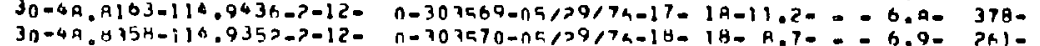

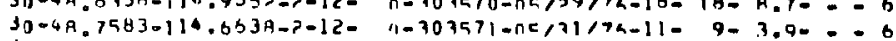
$30=4$ A.7769-114.7055-7-12- n-30757>-nद,71/74-12- 9-3.7-:-6.1- 95-

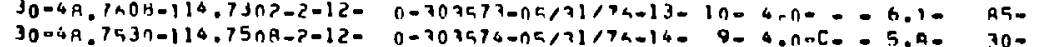

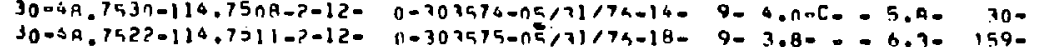

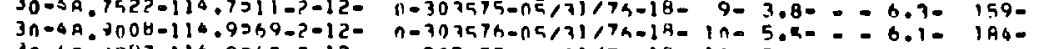
$30-49,0947-116.9347-2-12-0.003577-n a / 31 / 74-18-10-5.90=-0.3-184-$

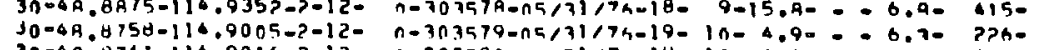
$30-49.8761-114.9016-2-12-0-3075 A 0-09 / 71 / 74-14-10-5.2--6.5-250-$

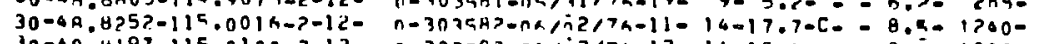

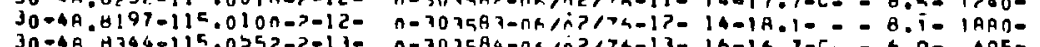

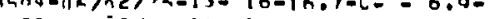

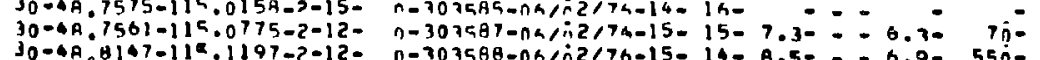

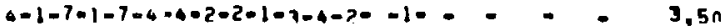
$7-1-7-2-7-3-4-2-2-1-4-4-7--1-=-\quad=\quad .00$

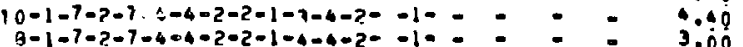
$A=1-7-3-7-4-4-3-2-1-4-3-2--3-=-\quad=\quad 3.10$ $10=1-7-3-2+70,-4-1-5-1=4-3-5=-1-2=0$

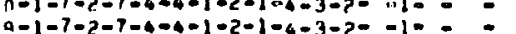

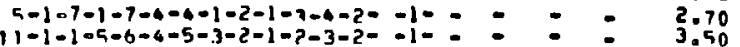

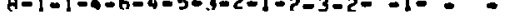

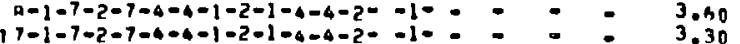
$17-1-7-2-7-4-4-1-2-1-4-4-2--10-5=0$
$19-1-7-2-7-4-4-1-2-1-4-4-2-10-30$ $150 \ldots=5.40$

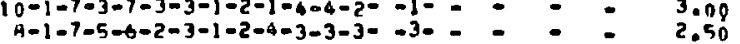

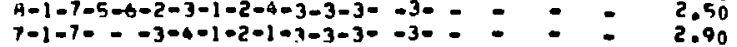
$4-1-7-5-6-3-4-2+1-1-3-3-3-3-3--\infty-2.50$

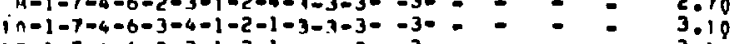
$1>-1-7-4-6-2-2-1-2-1-4-4-3--3-5=0: 3.10$ $10-1-7-4-6-3-3-1-2-2-4-3-3--3-\div \quad 2.90$ $1>-1-7-2-4-4-6-1-2-2-4-3-3--3-:=0 ; 030$ $17-1-7-2-6-4-6-1-2-2-6-3-3-3--10:=0: 03.3 n$ $5-1-7-5-6-2-3-1-2-1-4-3-2--1-\div=-\quad=1.70$

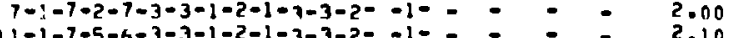

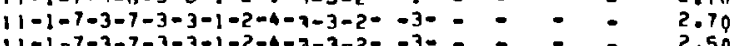
$11-1+7-3-7-3-3-1-2-4-7-3-2--3--\infty \quad-\quad 2.50$

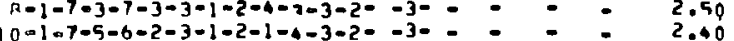

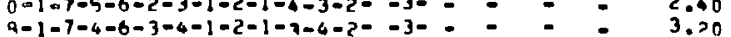
$17-2-7-2-7-4-4-2-2-4-7-4-4--1-=-\quad 030$

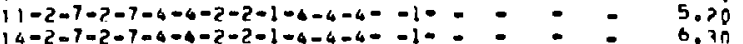
$10-2-7-3-7-4-4-1-2-1-3-4-3--1-=\div \div: 30$ $7-2-7-3-7-4-4-1-2-1-3-4-3--10=-\quad=3 . n 0$

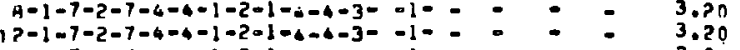
$11-1-7-3-7-4-4-1-2-1-3-4-3--1=$

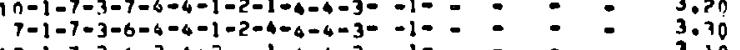
$17-1-7-3-6-3-4-20-1-4-4-3--1-=-\quad-\quad 3.10$

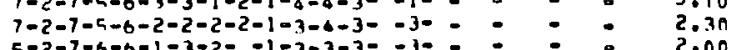
$A-1-7-3-6--1+-2-1+7-9-3--1-=:-2.10$

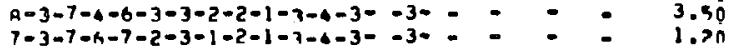




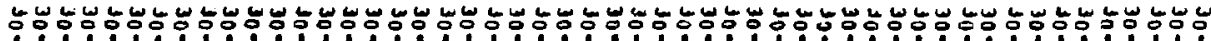
5: : :

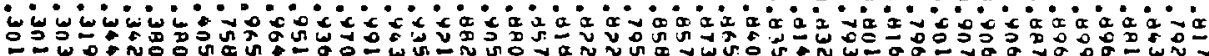

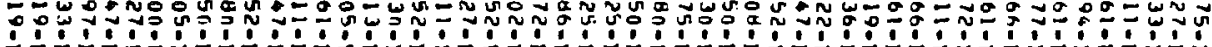

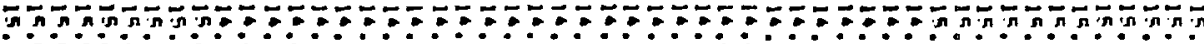
in unajojon:

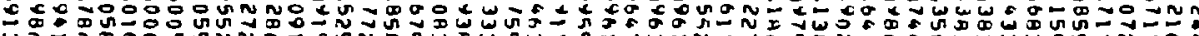
: : : : : : : 1 :

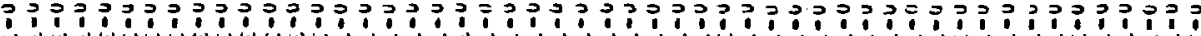

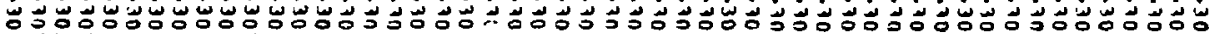

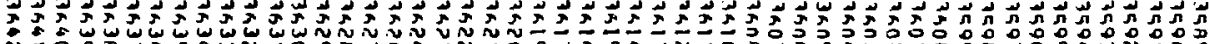

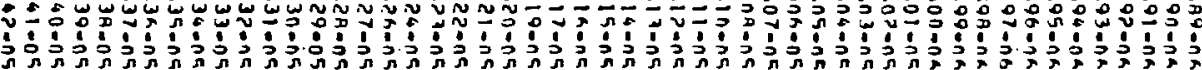

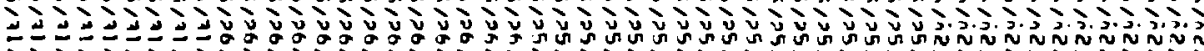

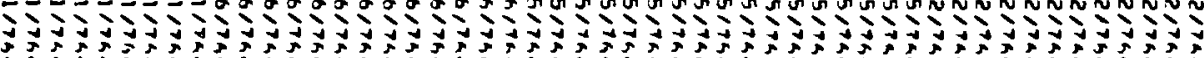

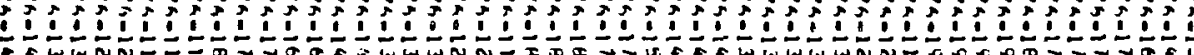

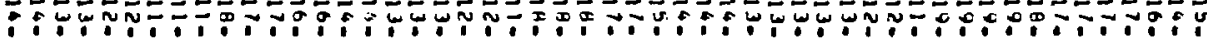

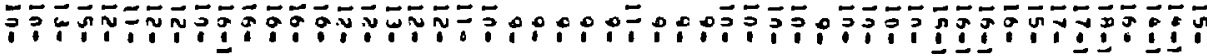

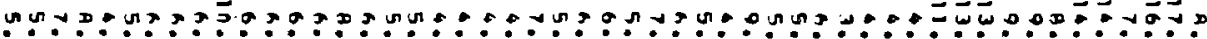

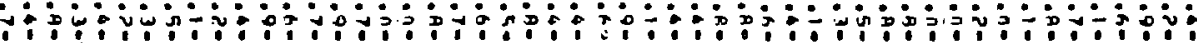
$\ldots, \ldots, \ldots, \ldots, \ldots, \ldots, \ldots, \ldots, \ldots, \ldots, \ldots, \ldots, \ldots, \ldots, \ldots, \ldots$

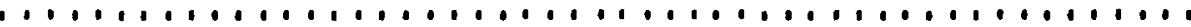

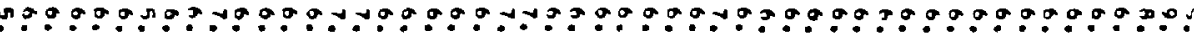
i >

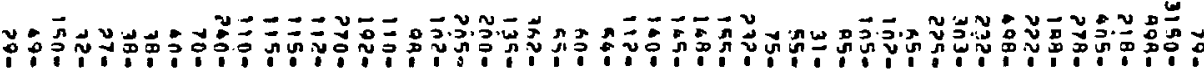

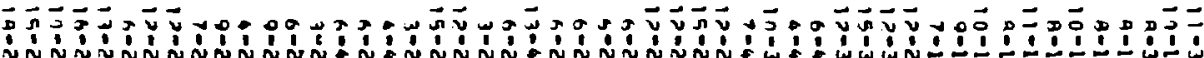

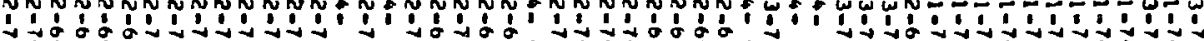

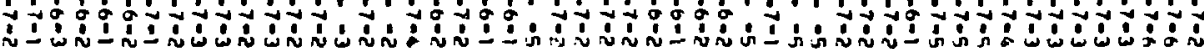

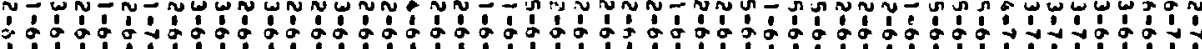
: 1 L

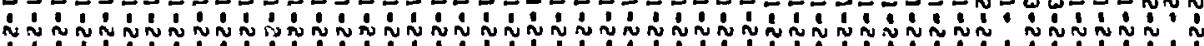

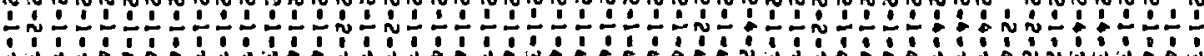
1: : : :

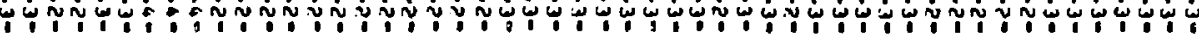

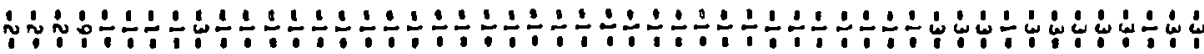

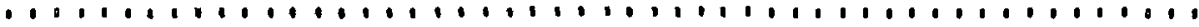

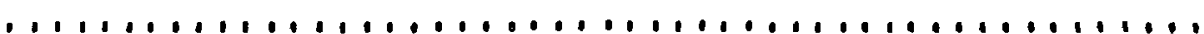

............................................

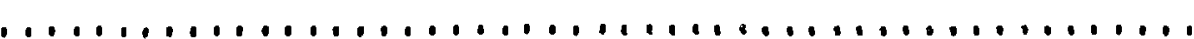

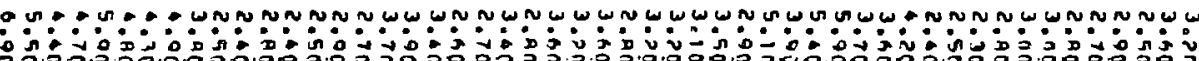

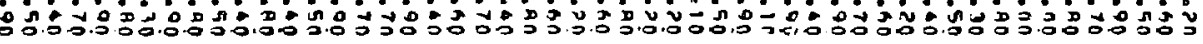

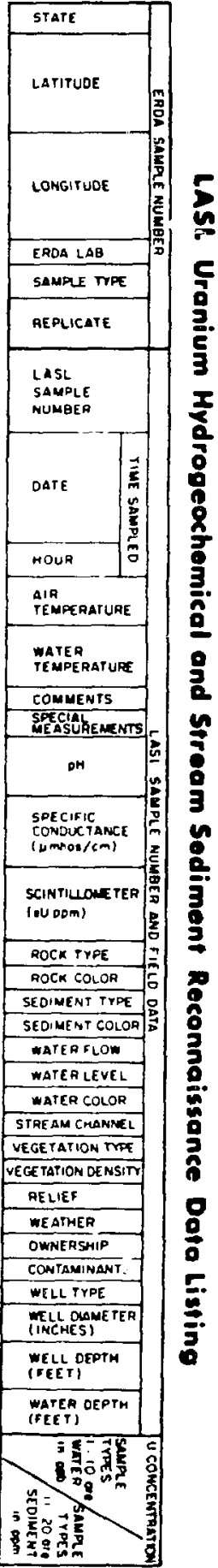




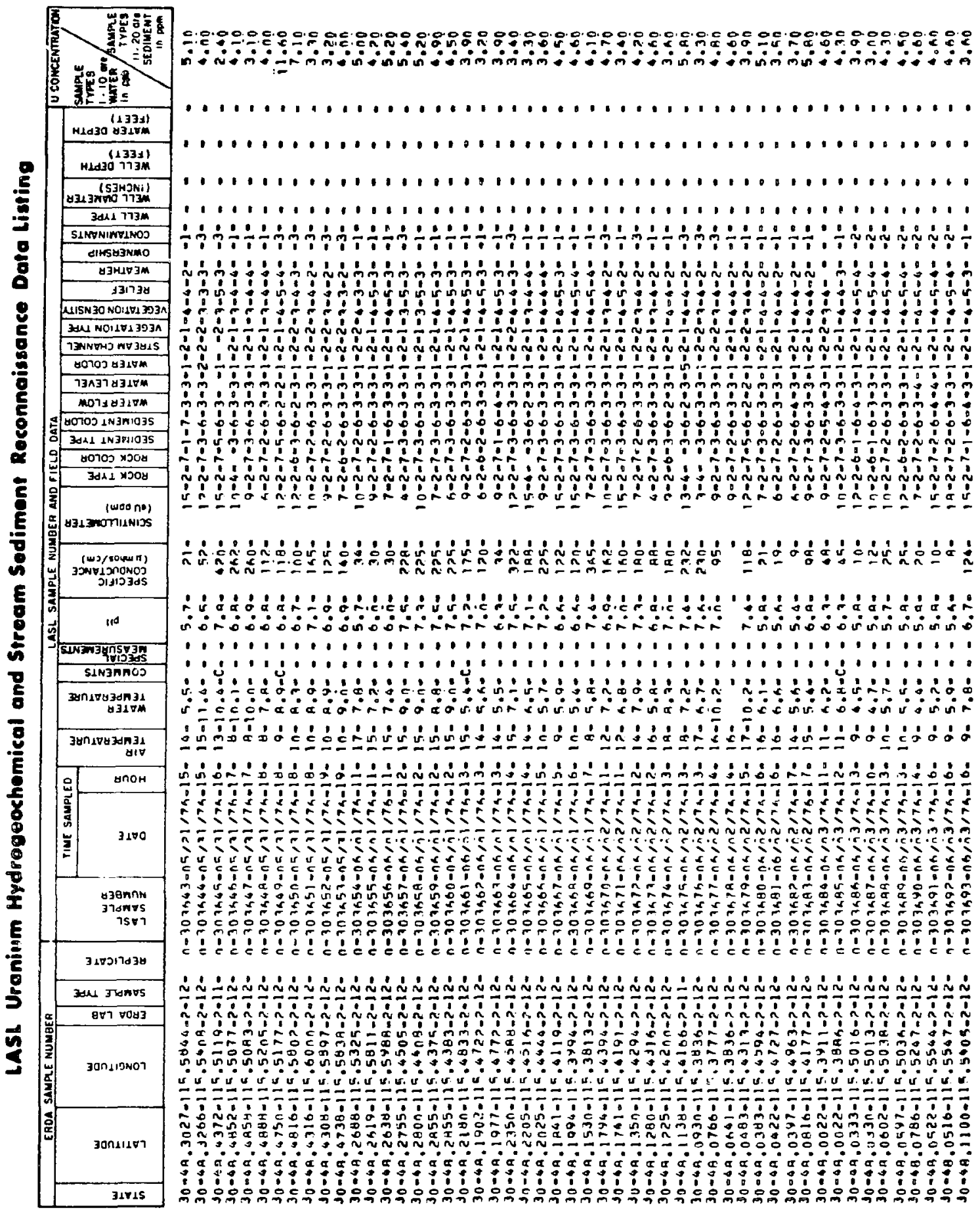


LASI Uranium Hydrogeochemical and Stream Sodiment Reconnaissance Data Listing

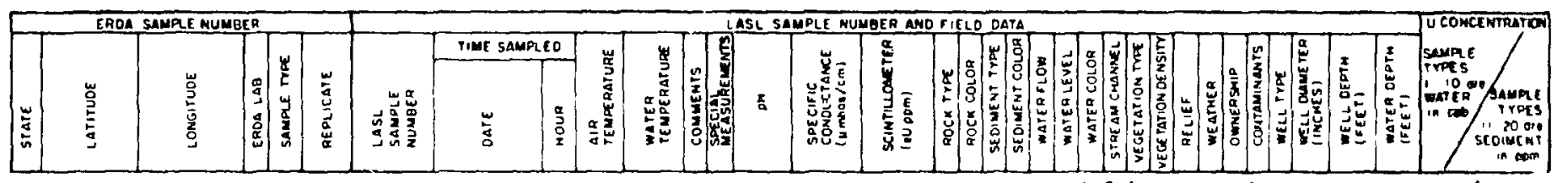

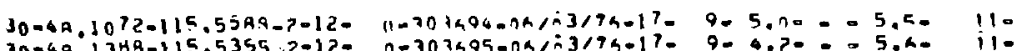

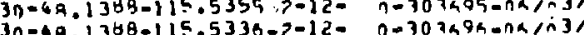

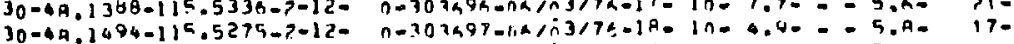

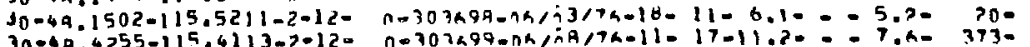

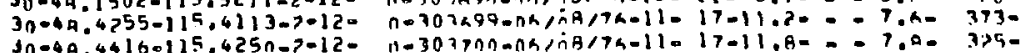

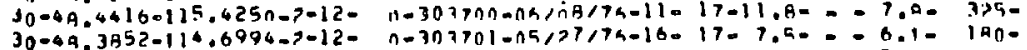

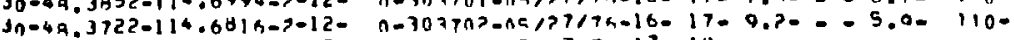
$30-4 R_{0} 3558-114.7094-7-15-0-301703-n 5 / 77,74-17=19-0=-\infty=$ $30=4$, उ5l9-114.6947-7-12

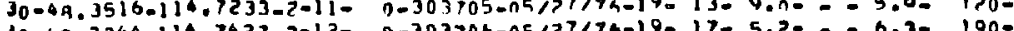
30 -4A.3744-1140.

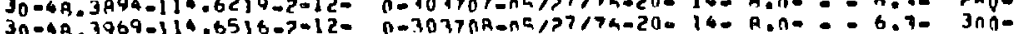

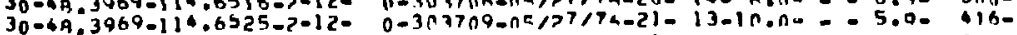
$30-48,3602-114.6561-2-12-0-30371 n-05 / 77 / 76-21=13-6.7-=-6.5=3200$

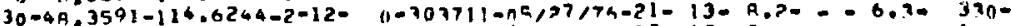

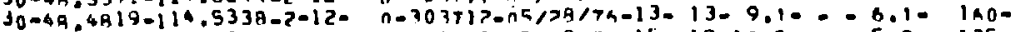

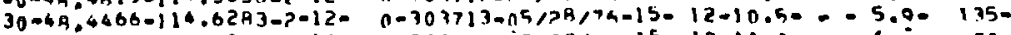

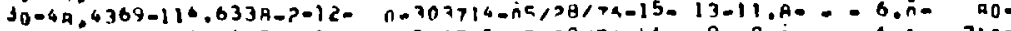

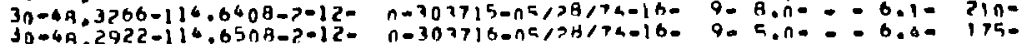

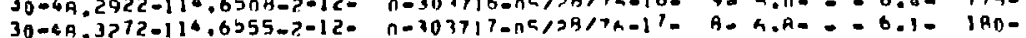

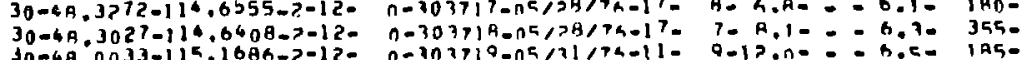

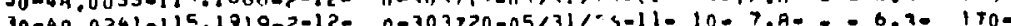

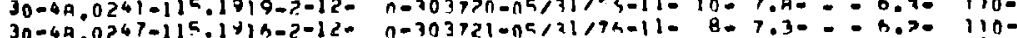

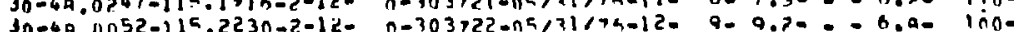

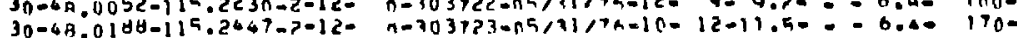
30-4R. 0425-115.2113-7-12- n-303724-05/11/14-13-1n-B.8-C- - 6.4- 10?-

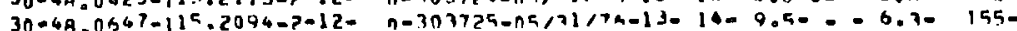

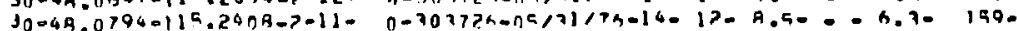

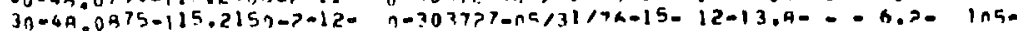

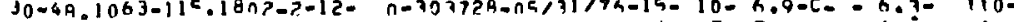

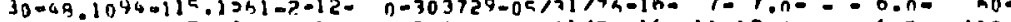

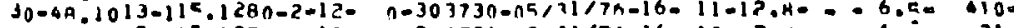

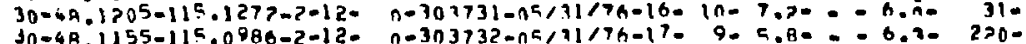

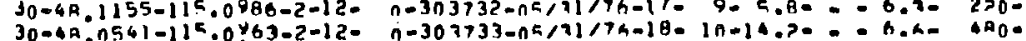

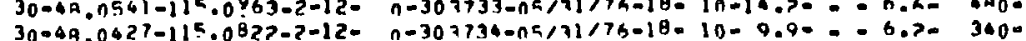

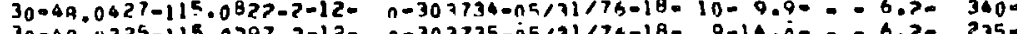

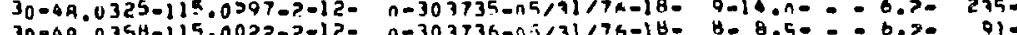

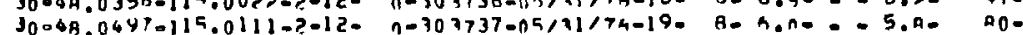

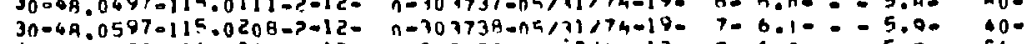

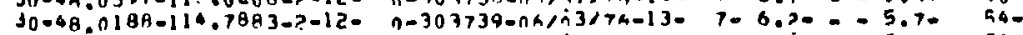

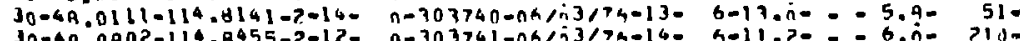

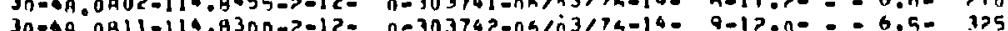

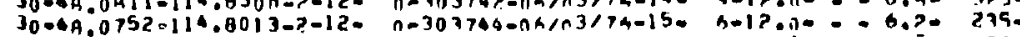

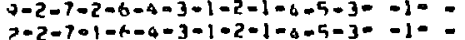

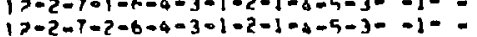
$9=2-7-2-6-3-3-1-2-2-7-5-3--1-$. $9-2-7-2-6-6-4-3-1-2-1-7-5-5-2--1-$
$9-2-7-2-6$

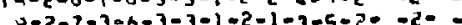
$10-1-1-4=1-3-3-1-2-1-7-3-2--3-0$ 1 1)-1-1-4-6-4-4-1-3-3-3-2-2- - 3- $1>-1=1-5-6--1--2-1-1-6-2=-1=$ $18-1-1-6-A-4-4-1-2-1+3-4-1--1=$

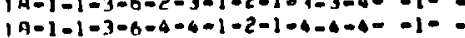

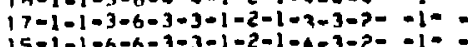

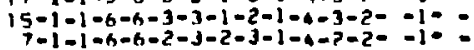
$2-1-1-3-h-4-3-1-2-1-4-3-2--1=$ $1 A-1-1-6-A-4-3-1-2-1-4-3-6--10=$ $17-1-1-3-5-4-4-1-2-1-4-3-2--3=$
$15-1-1-3-6-4-4-1-3-1-4-2-2=-1=$ $17-1-1-3-6-3-3-1-2-1-4-3-2=-1=$ $17-1-1=3-6-4-3-1-2-1-4-3-2--1=$
$15-1-1-3-6-4-3-1-2-1-3-4-2-1=$ $7-1-1-3-6-4-3-1-2-1-4-4-2-1-1=$ $1>-1-1-5-6-4-3-1-2-1-4-3-2--1=$

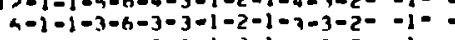
$9-1-1-3-6-2-3-1-2-1-9-3-2--1=$
$7-1-1-3-6-3-3-1-2-1-7-3-2-1$

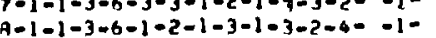
$33-1=1-3-1-3-3-5-5 \cdot 1-4-3-5--3=$ $19-1-1-7-1-3-3-1-2-1-2-2-2-3-3-$
$19-1-1-6-6-2-3-1-3-1-3-7-5=-30$ $1 n-1-1-6-6-2-3-1-3-1-3-7-2=-30$ $12-1-1-3-6-2-3-1-2-3-2-4-2-10-10=$
$13-1-1-6-8-1-2-1-3-1-3-2-5-10$

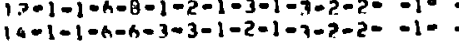

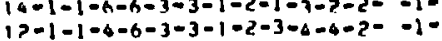

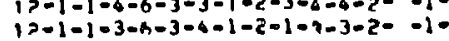
, $1-1-1-3-6-6-3-1-2-1-9-3-2--10$ $1-1-1-3-6-4-4-1-2-1-9-4-1--1-$ $10=1-1-3-7-3-4-1-2=1-3-2+3--1=$ $14-1-1-4-6-2-6-1-3-1-3-2-30-1)=$ $15-1-1-3-6-3-3-1-2-1-7-3-4-010$ $11-1-1-3-6-4-3+1-2-1-4-3-3--1-$

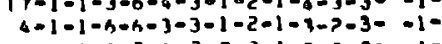

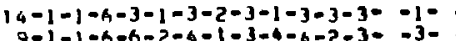

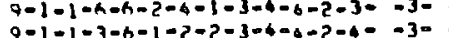

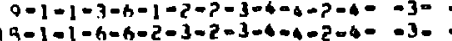

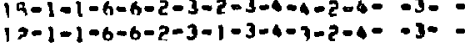

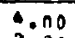

3.00

$\because n$ o

3.90
3.90

5.50

$3.2 n$

5.90

5.20

3.50

$\because 10$

$\because 10$

2.30

3.50

2.7n

5.100
2.80

2. An

5

3.50

3.70

2.60
$\because .80$

$\because-10$

4.90

3.70

3.70

.20
.850

0.50
2.70

12.70

5.Ap

2.00
5.00

5.60
2.40

2.40
2.30

3.10

3.40

3.60

0.30

0.30
2.40

3.40
.90

3.00

3.69
2.60 


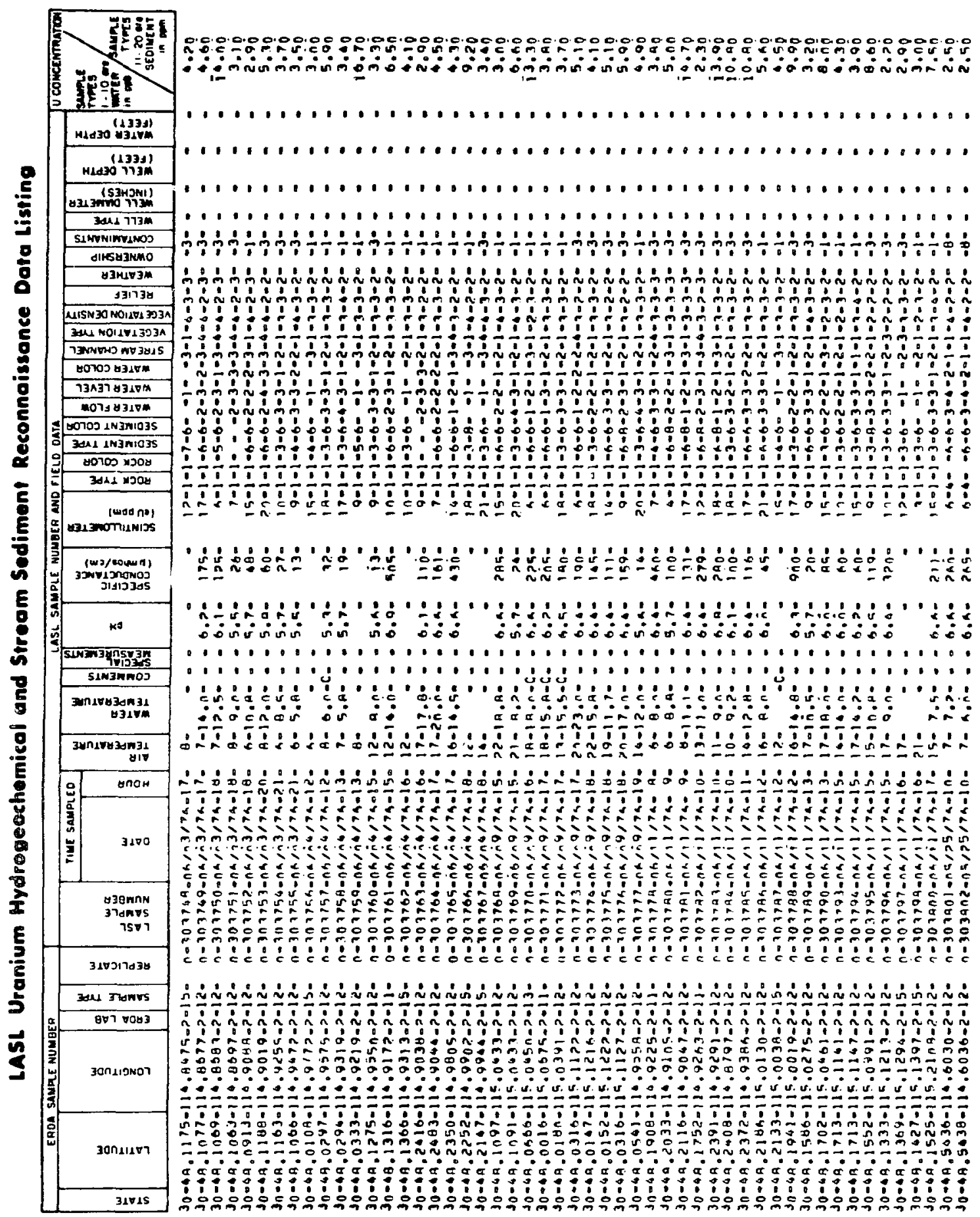




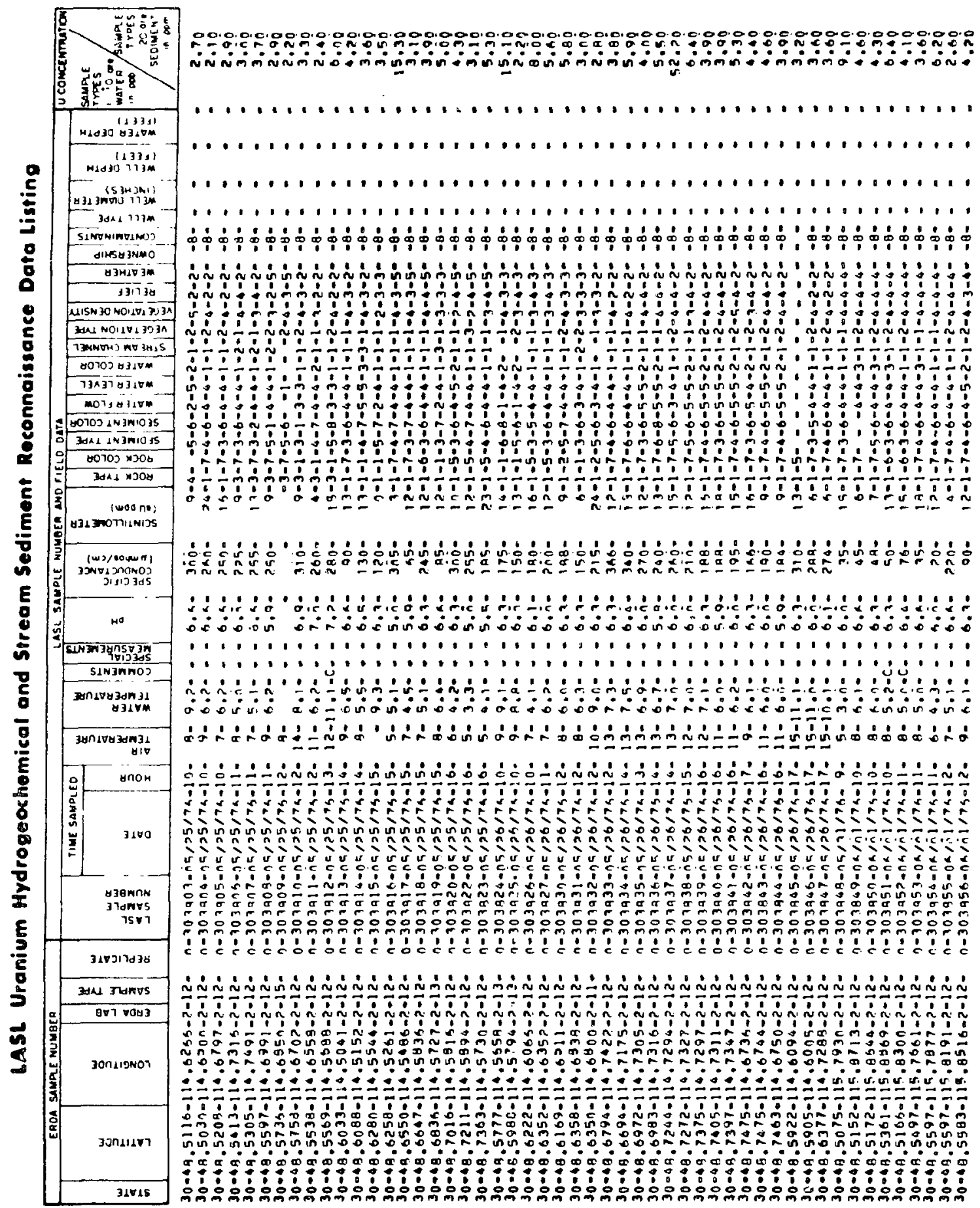




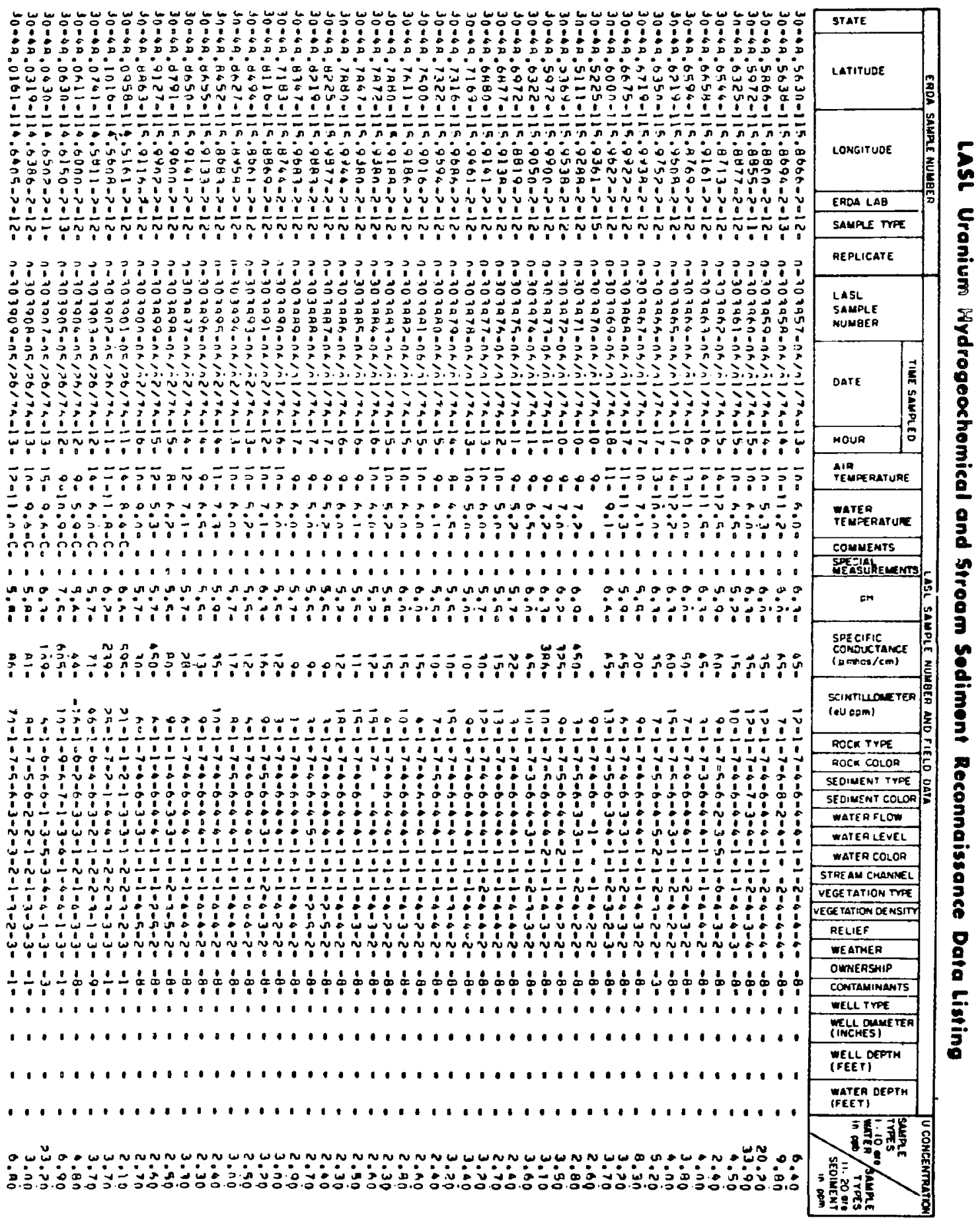




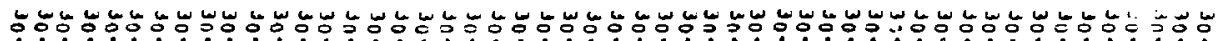

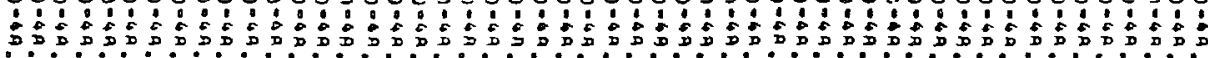

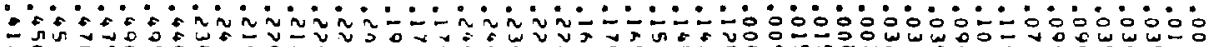

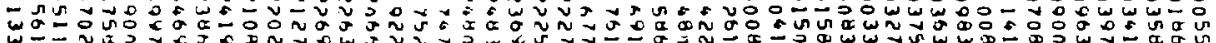

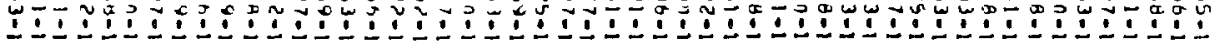

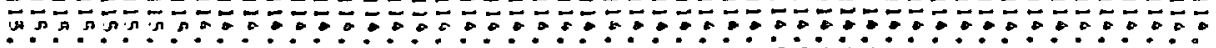

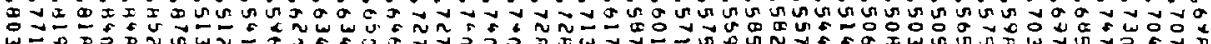

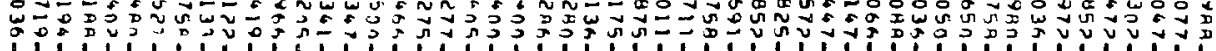

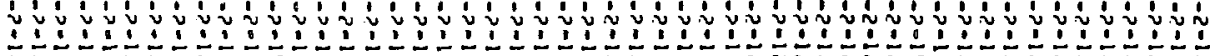

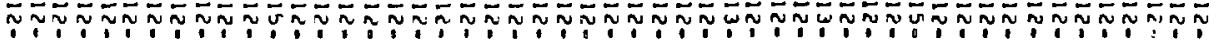

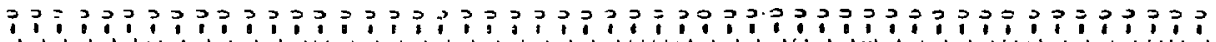

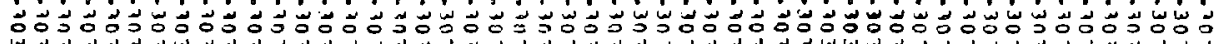

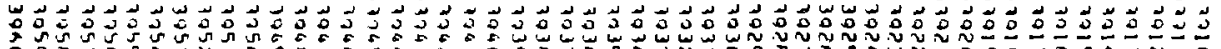

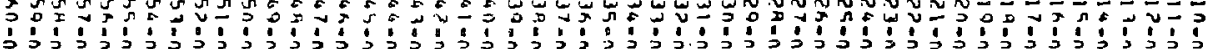

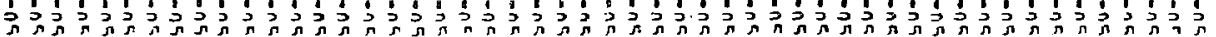

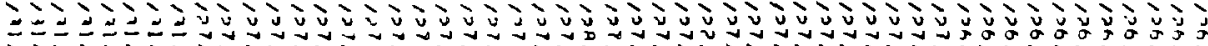

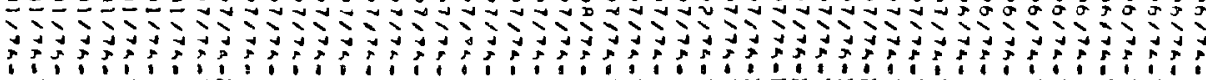

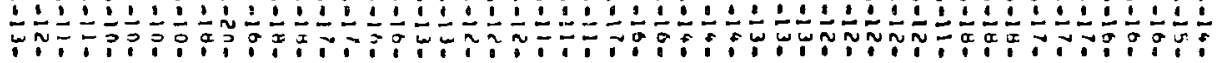

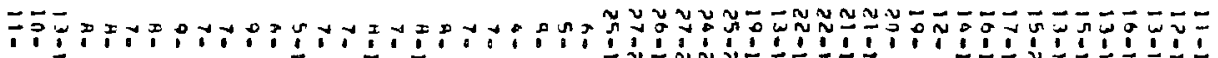

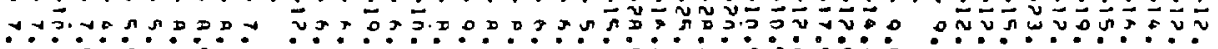
:

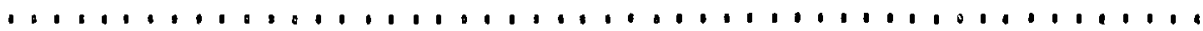
munn

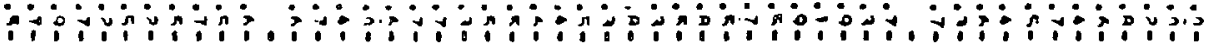

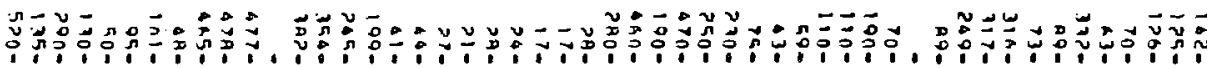

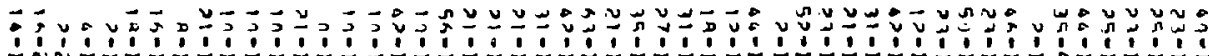

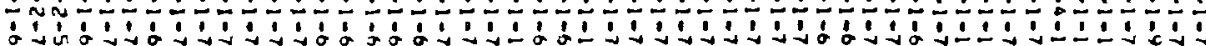

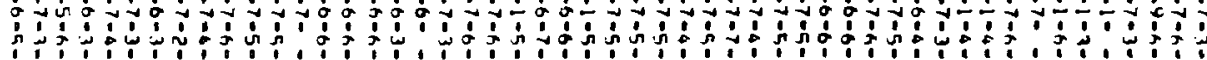

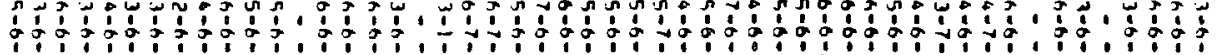

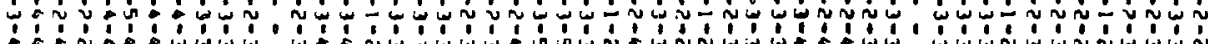

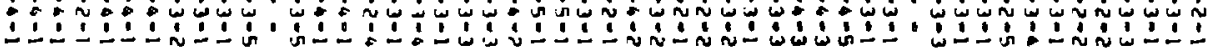

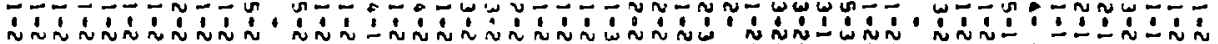

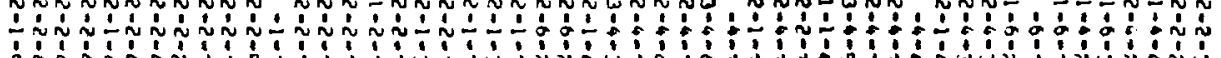

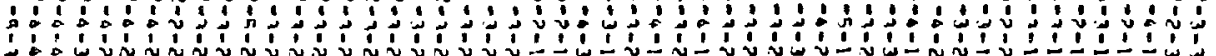

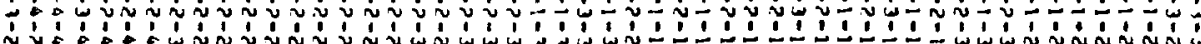

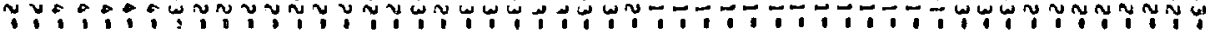

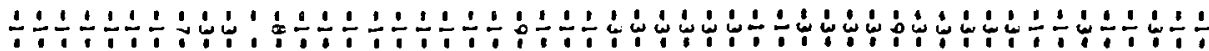

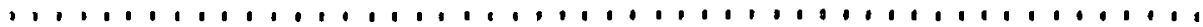

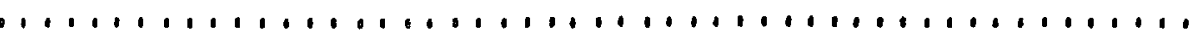
.

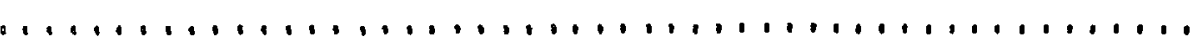

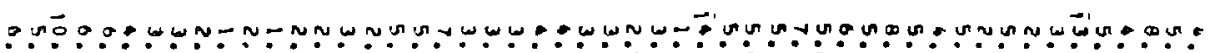

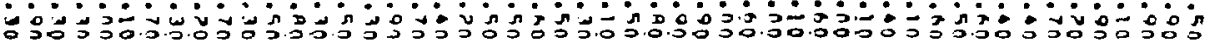

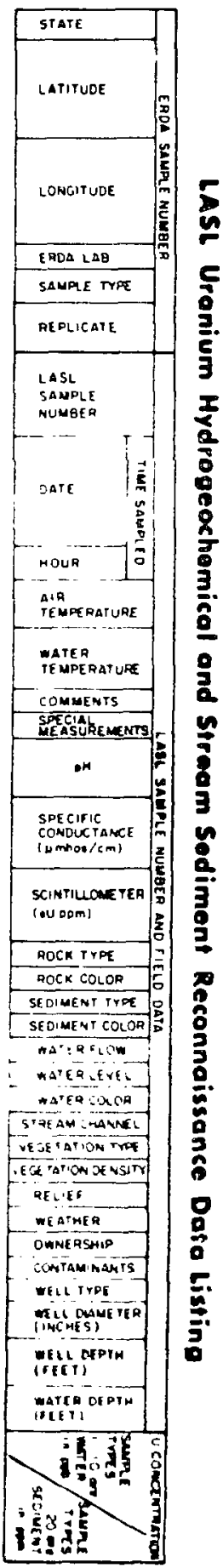




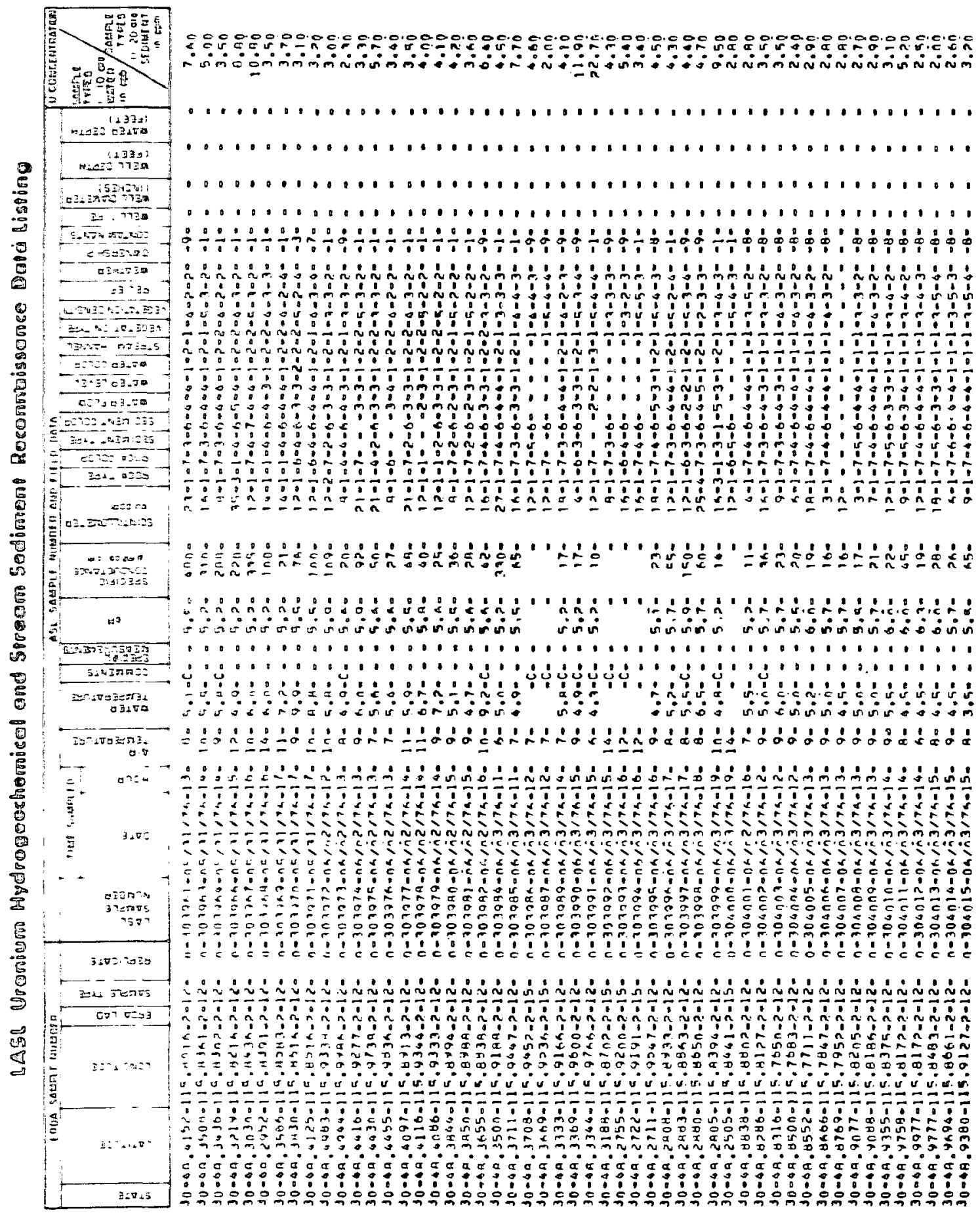


LASL Uranium Hydrogeochemical and Stream Sediment Reconnaissance Data Listing

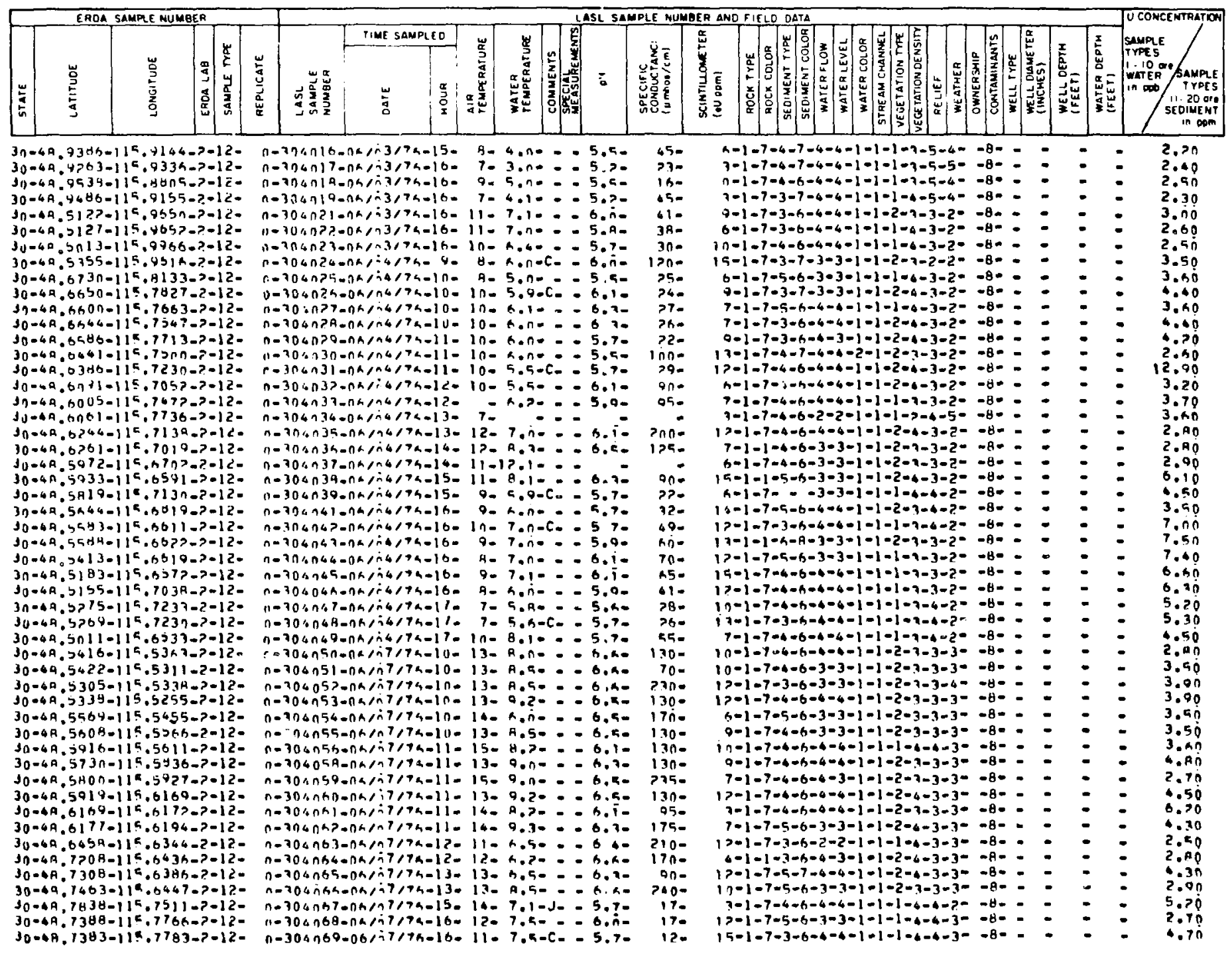




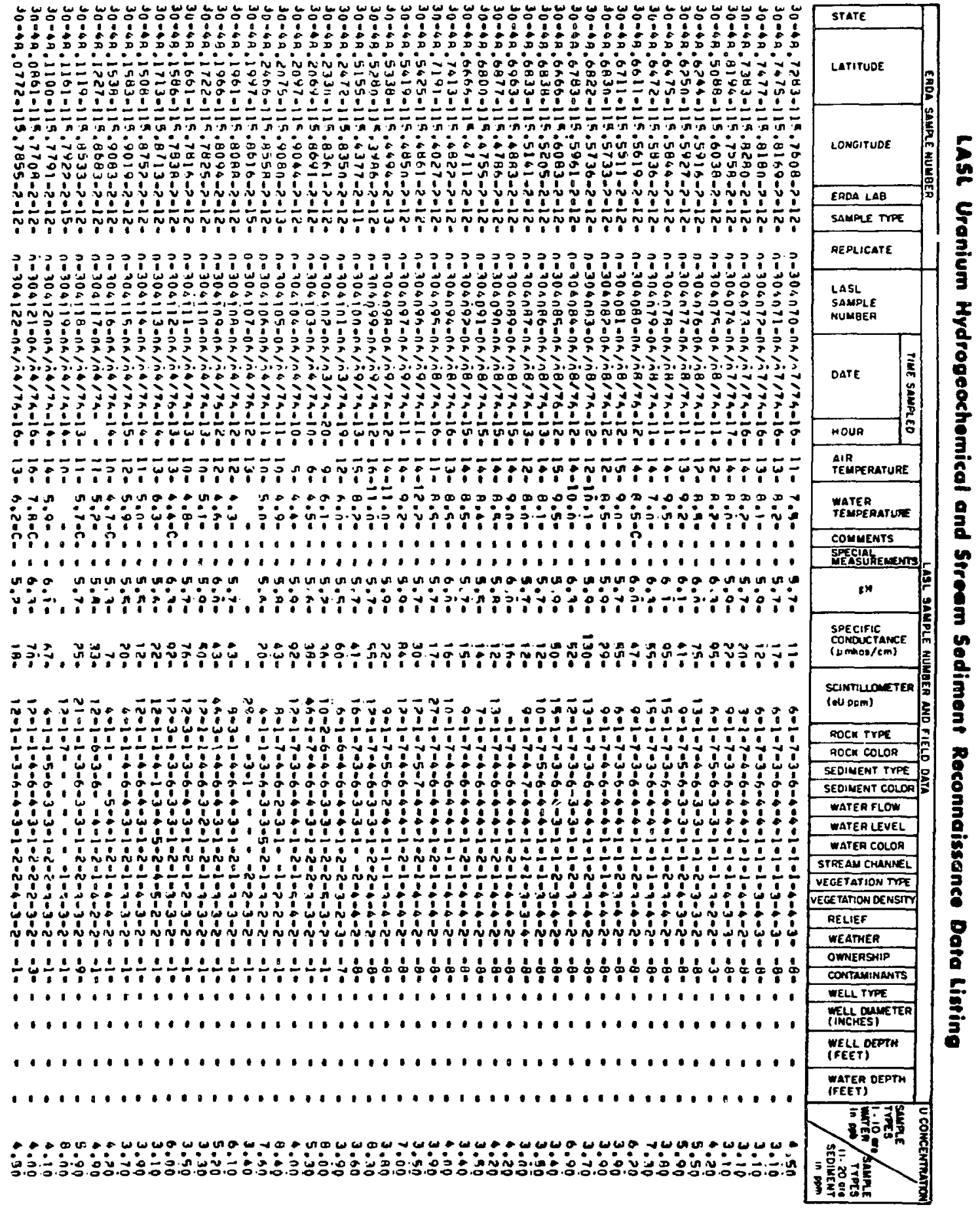




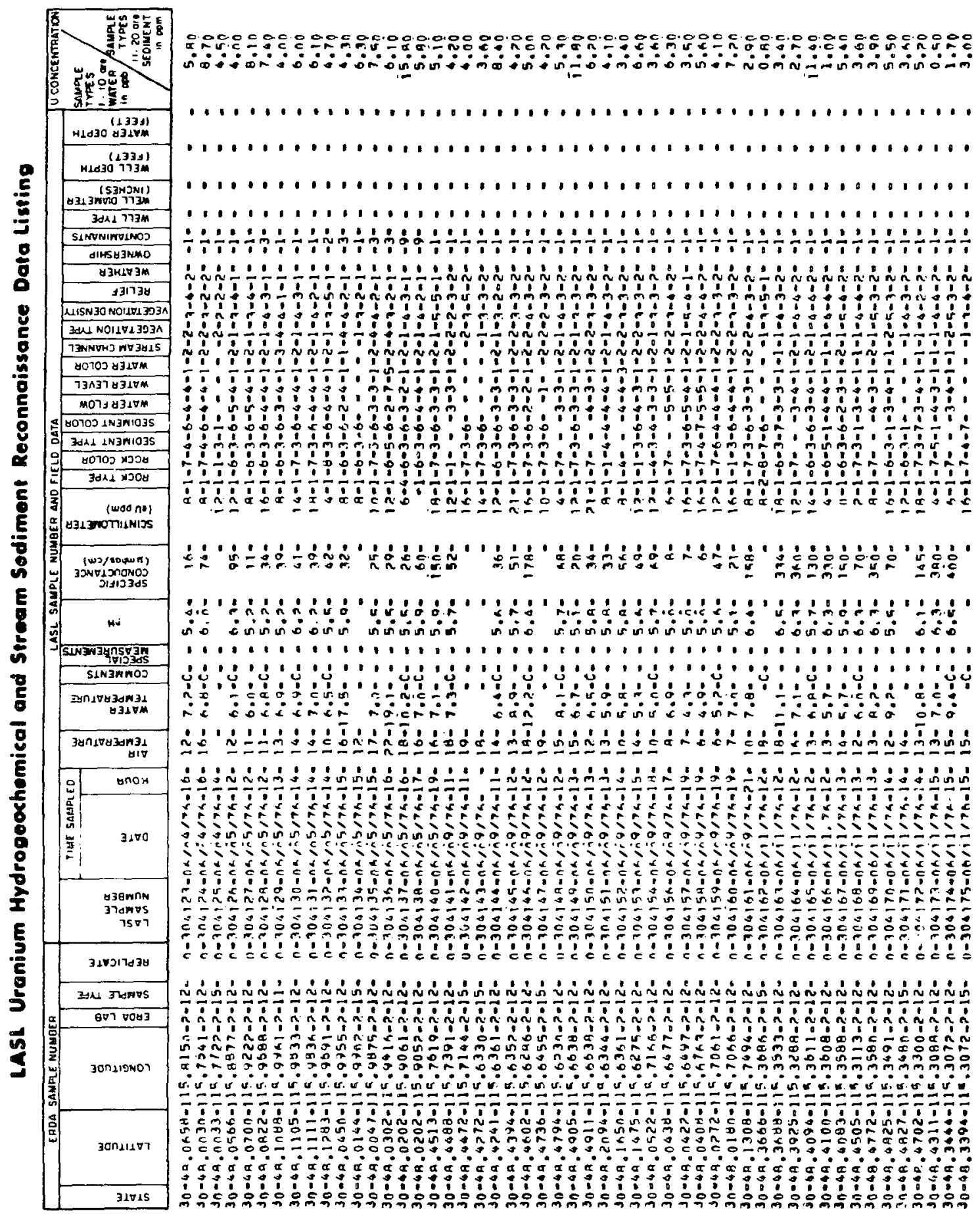




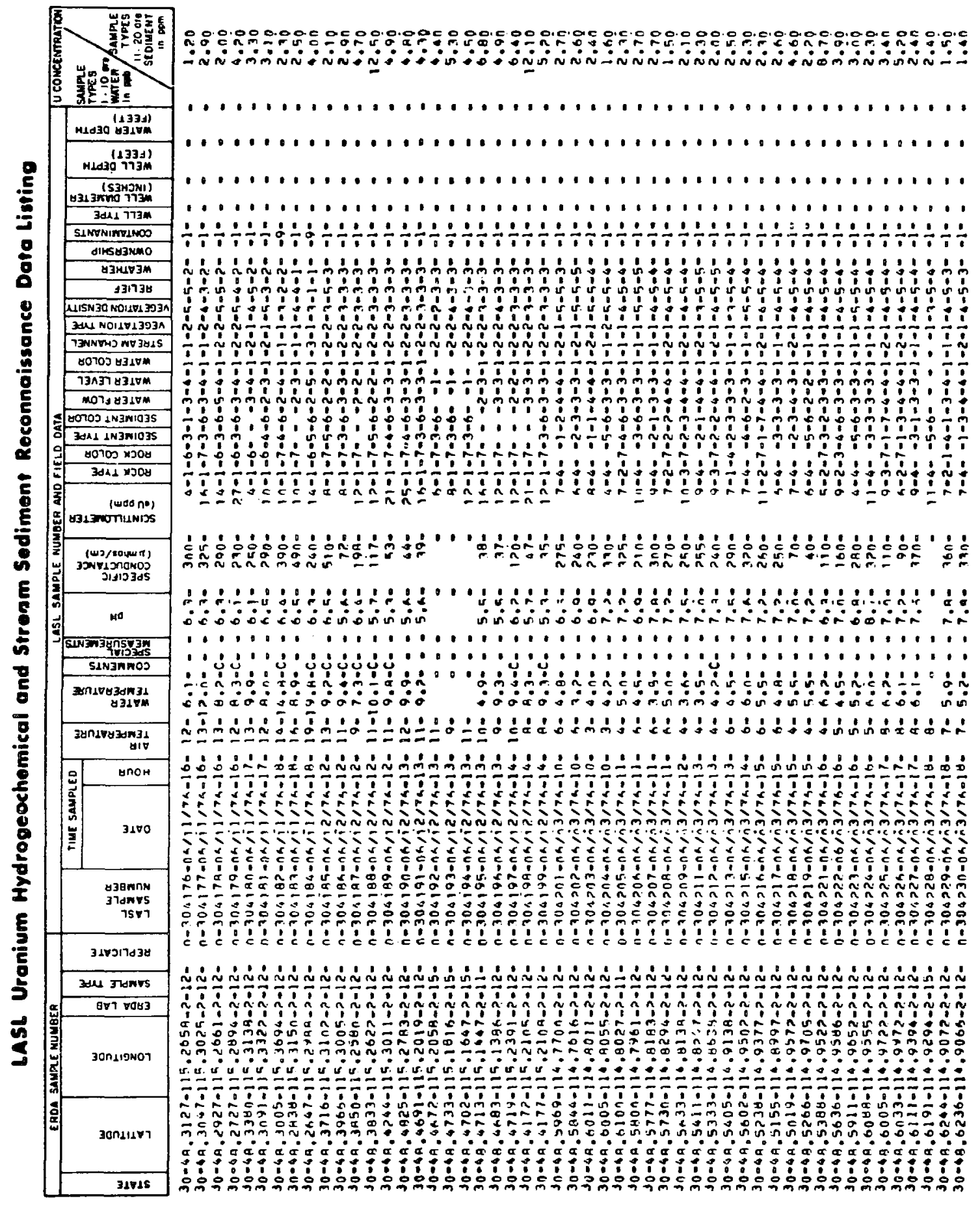




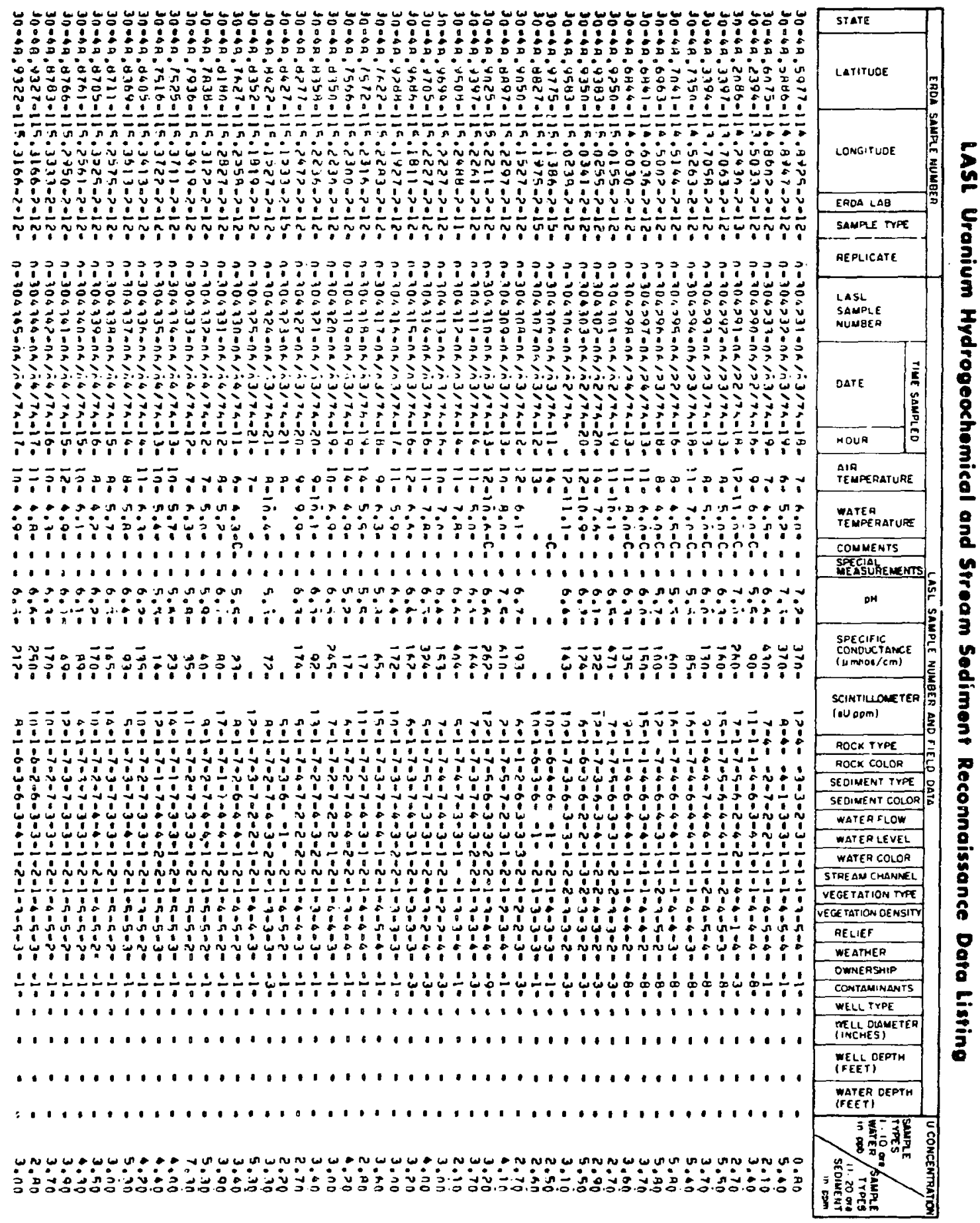




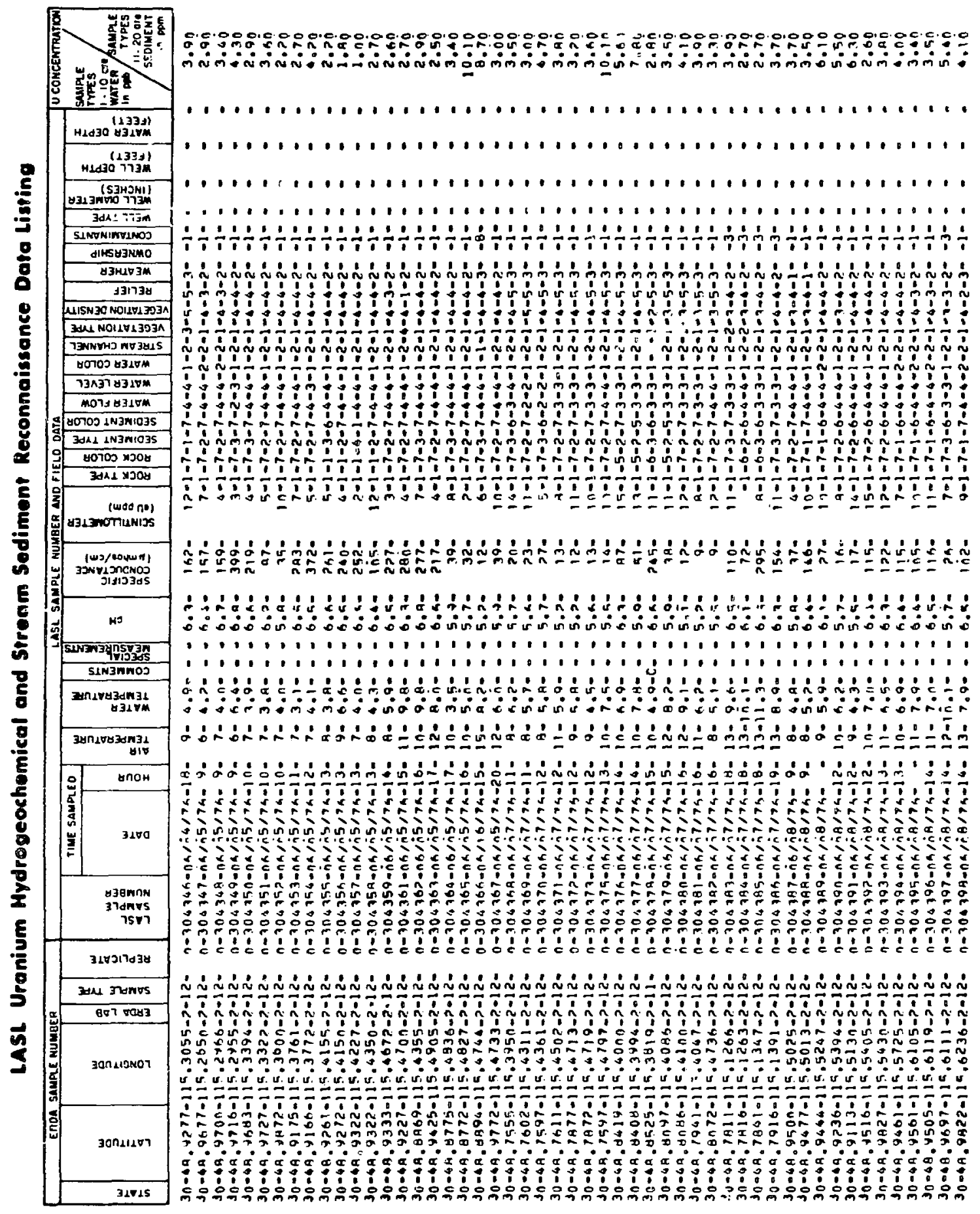




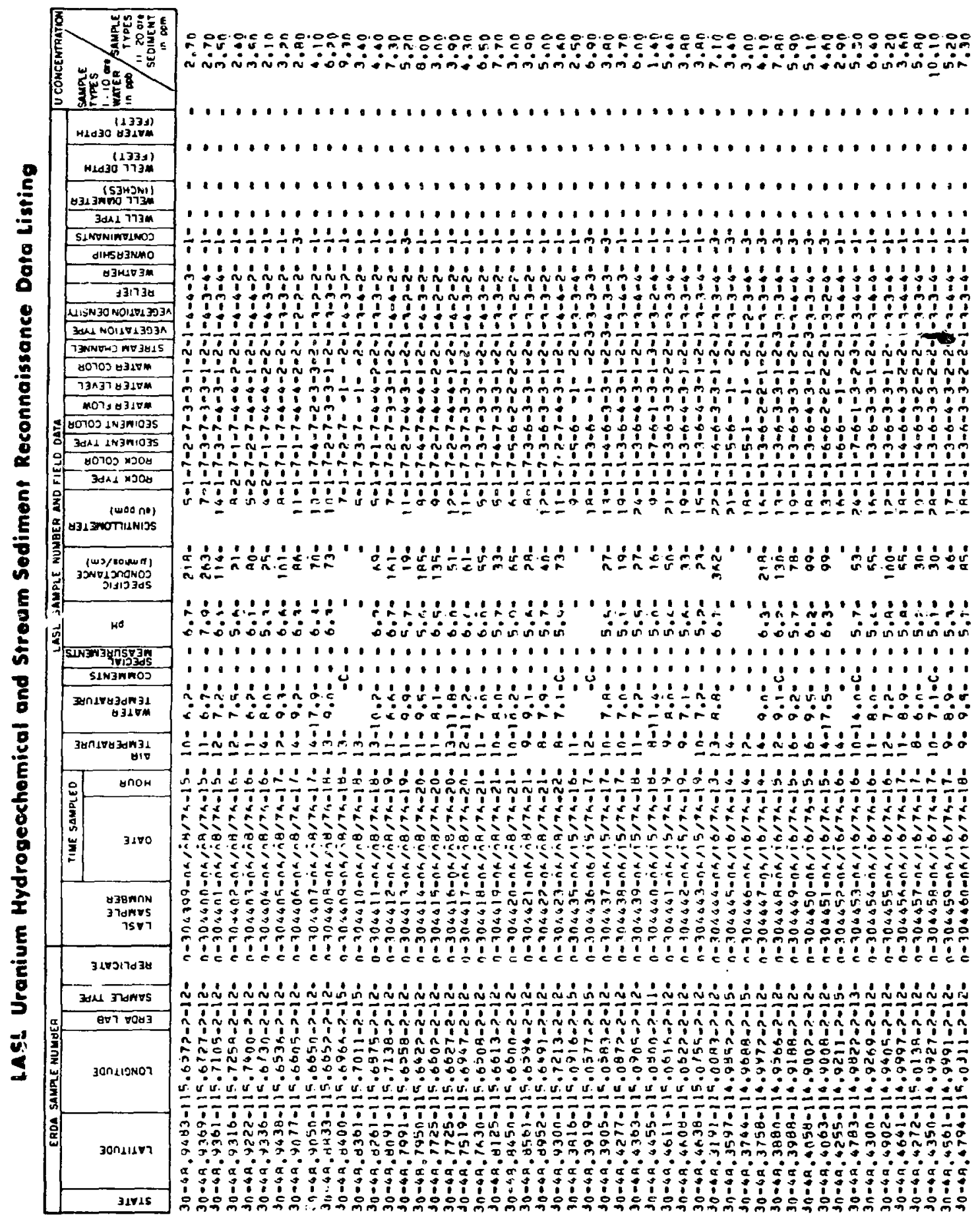




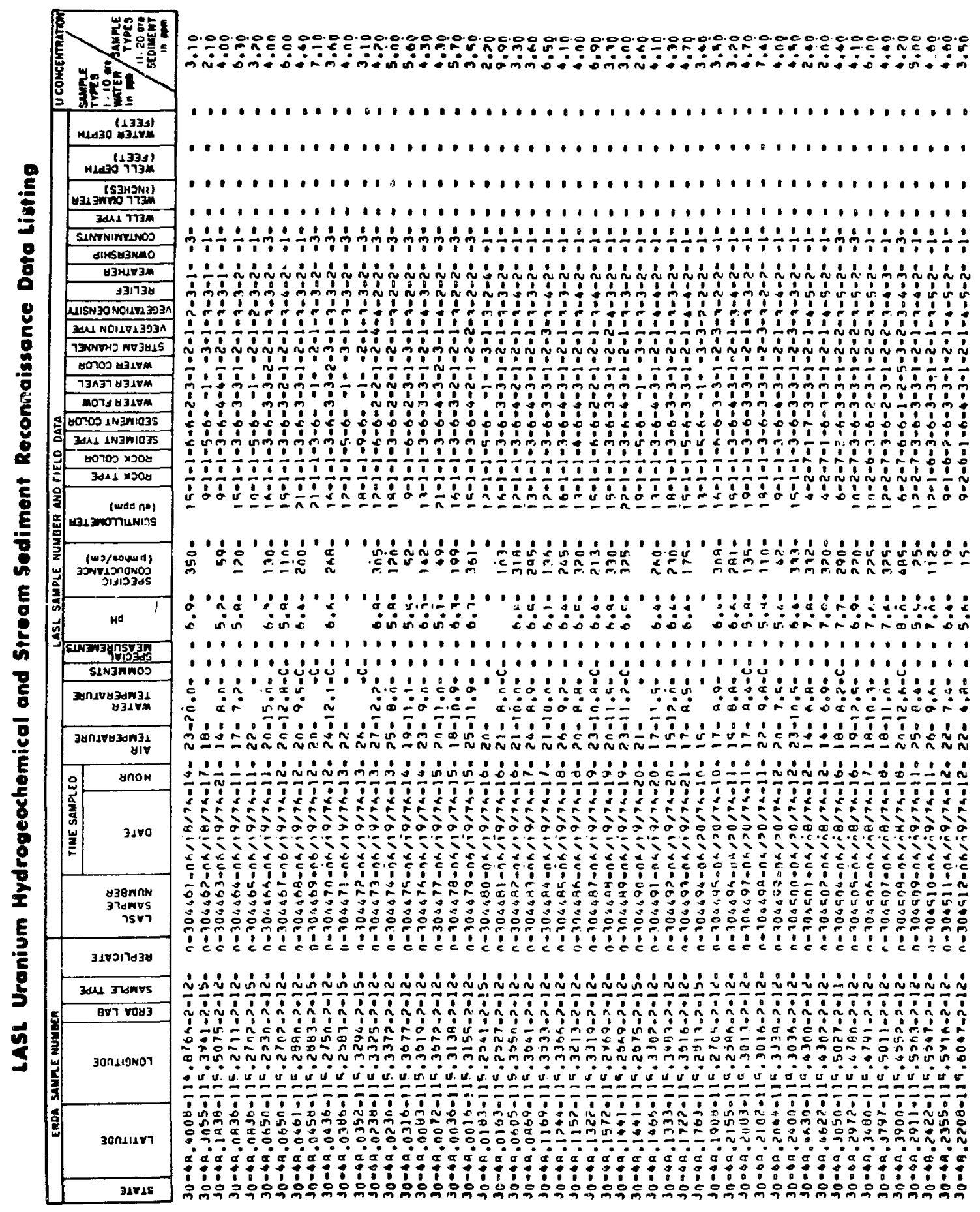


$62-a$

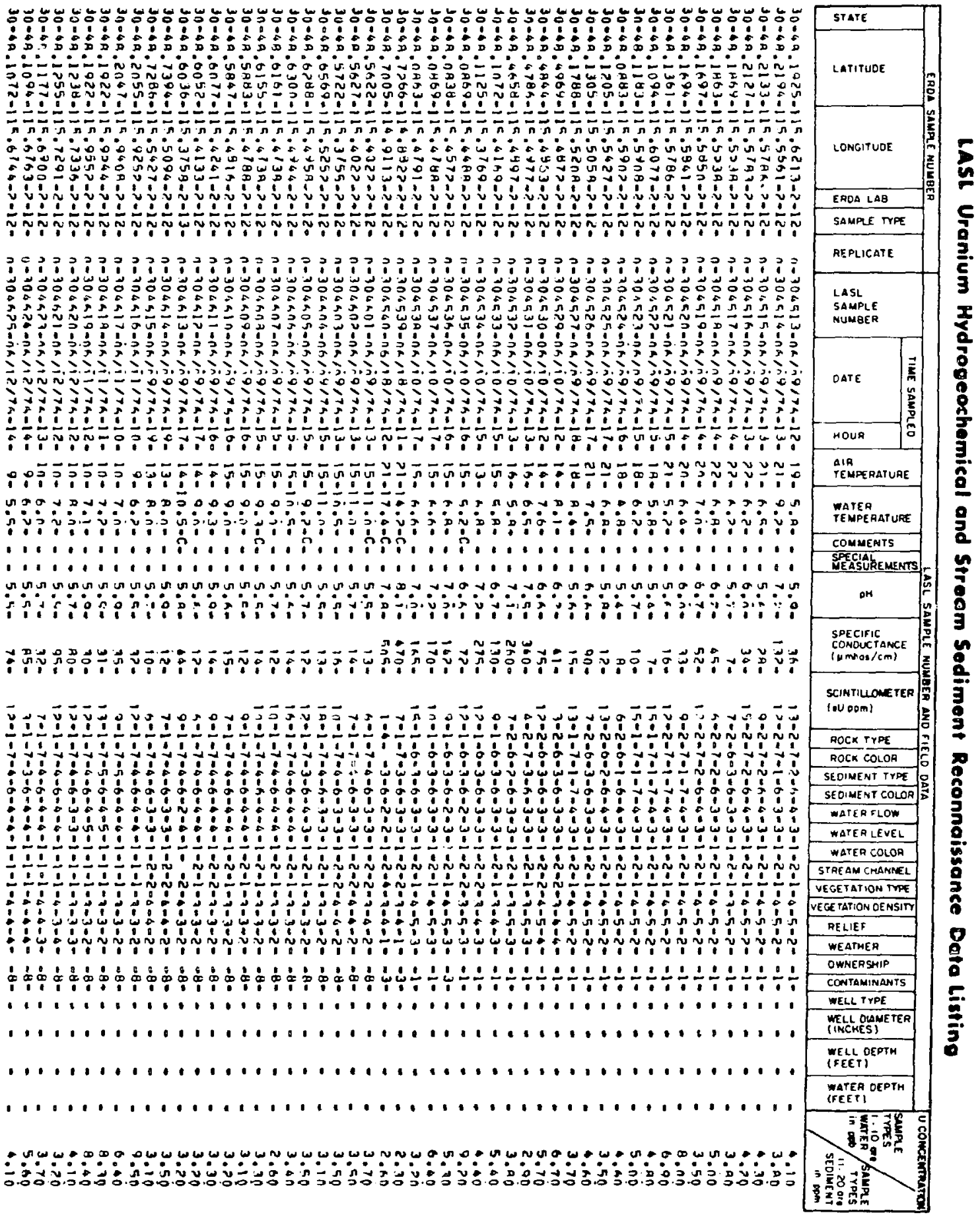




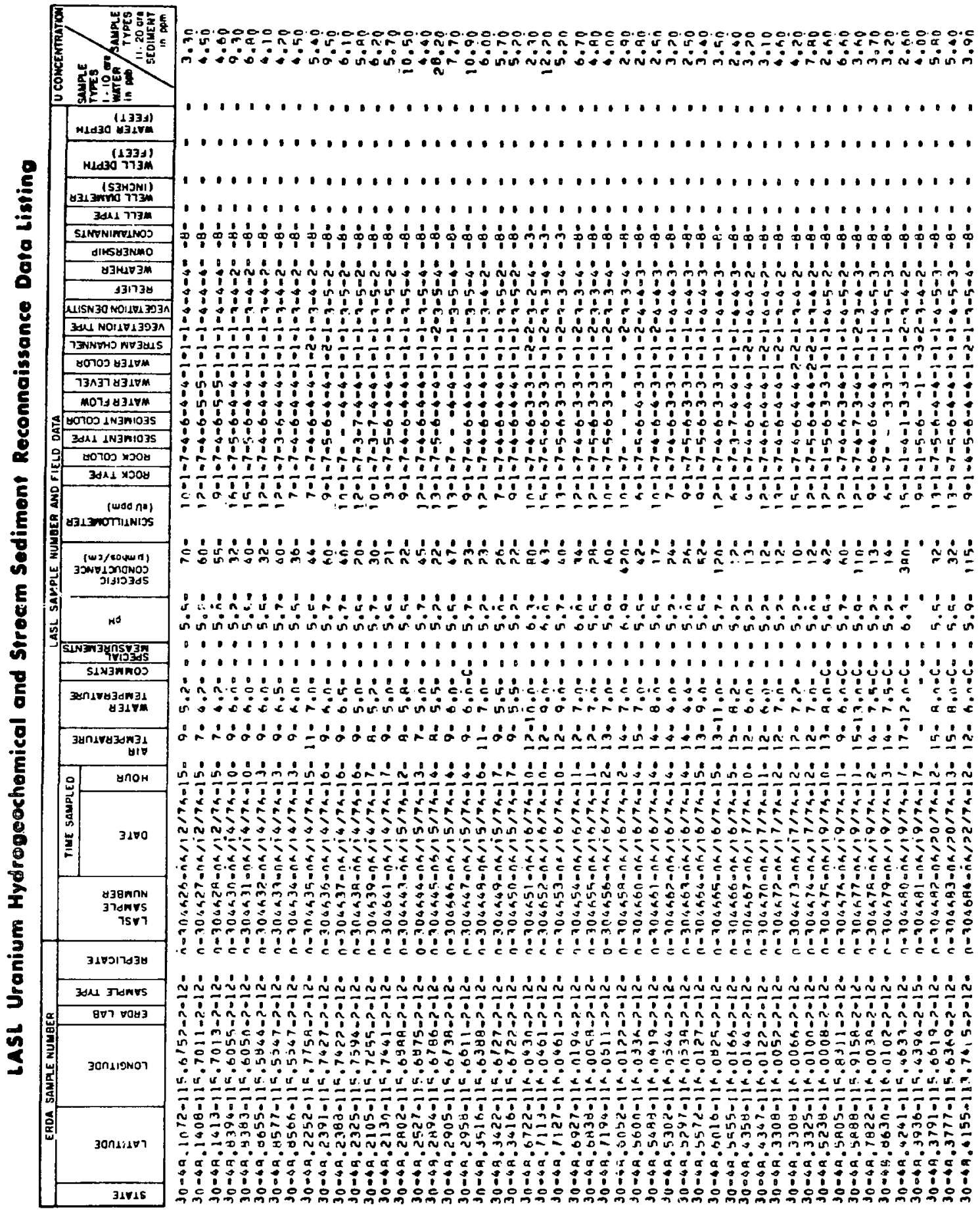




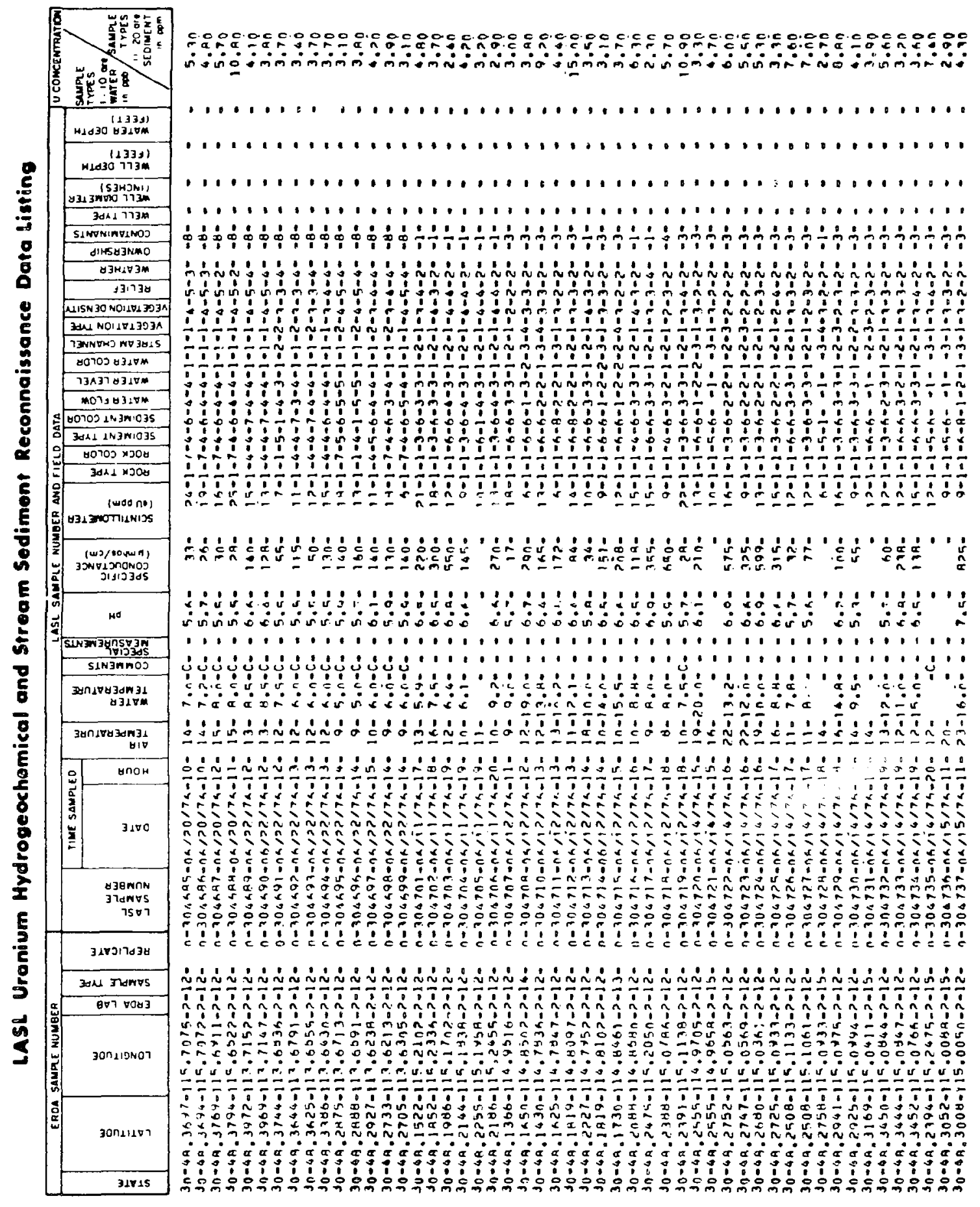




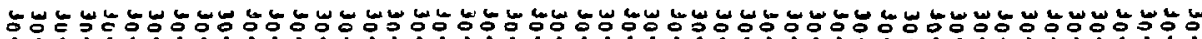

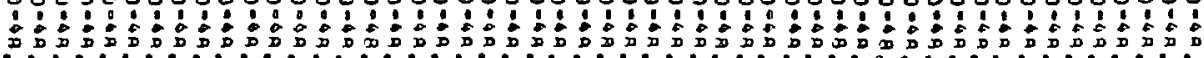

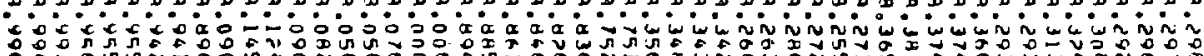

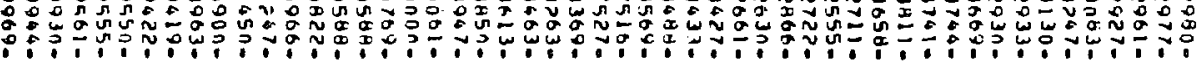

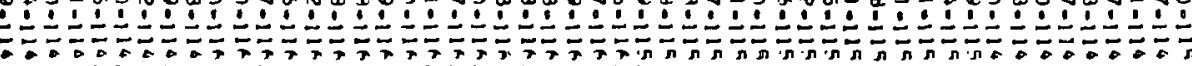

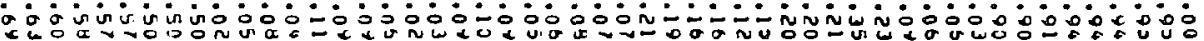

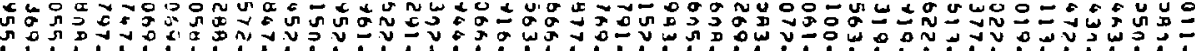

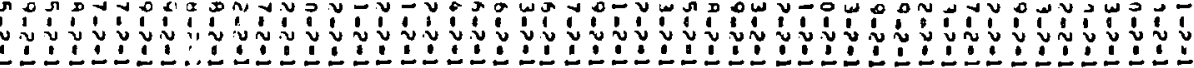
ה

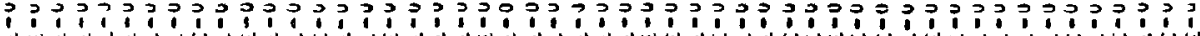

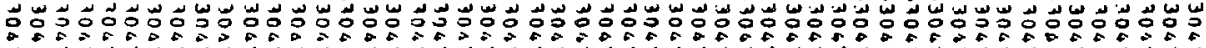

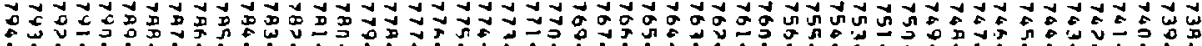

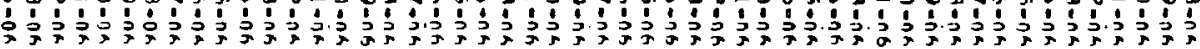
jù

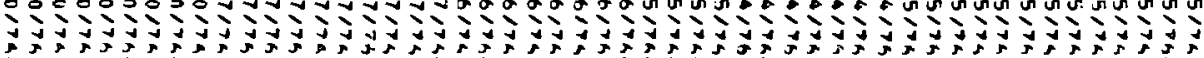

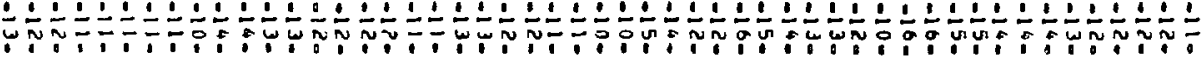

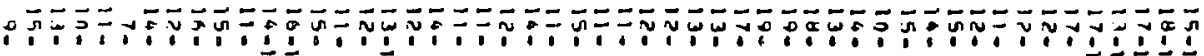
แ 定

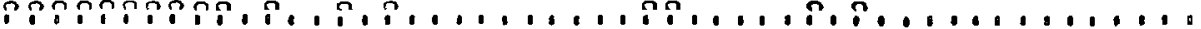

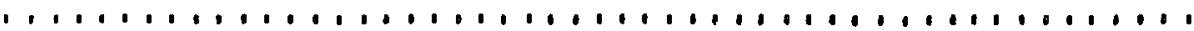
vi v v

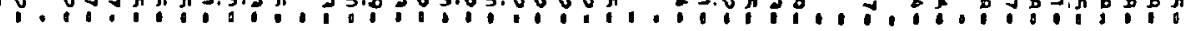

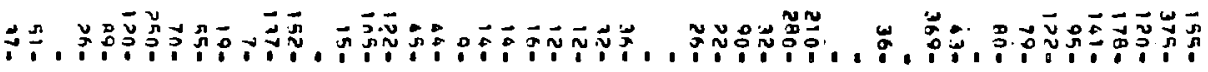

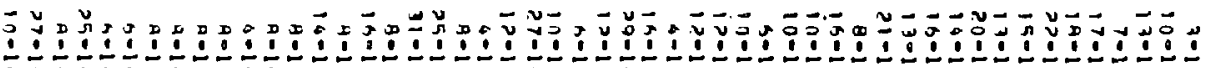

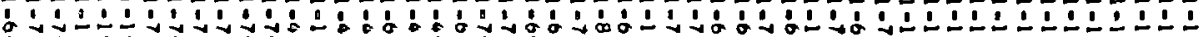

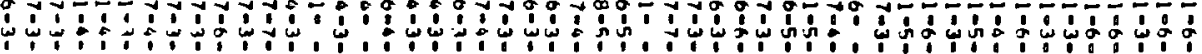

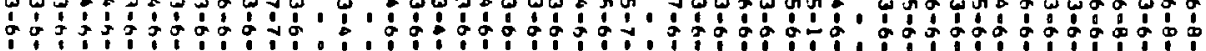
: :

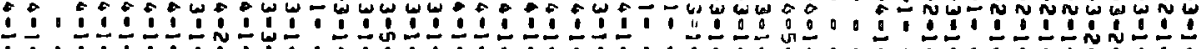

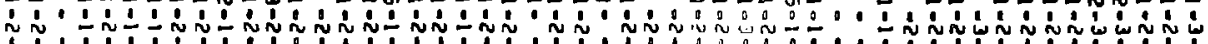

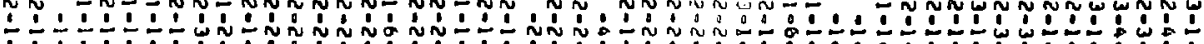
1

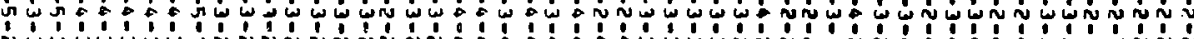

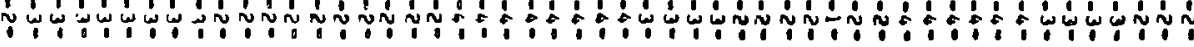
:

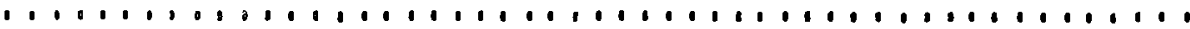
$\ldots, \ldots, 1, \ldots, \ldots, \ldots \ldots \ldots, \ldots, \ldots, \ldots, \ldots, \ldots, \ldots, \ldots, \ldots, \ldots, \ldots$ $, \ldots, \ldots, \ldots, \ldots, \ldots, \ldots, \ldots, \ldots, \ldots \ldots \ldots \ldots \ldots$ $\ldots \ldots \ldots \ldots \ldots \ldots \ldots \ldots \ldots \ldots \ldots \ldots$

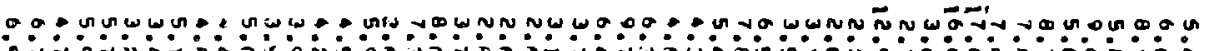
ค.

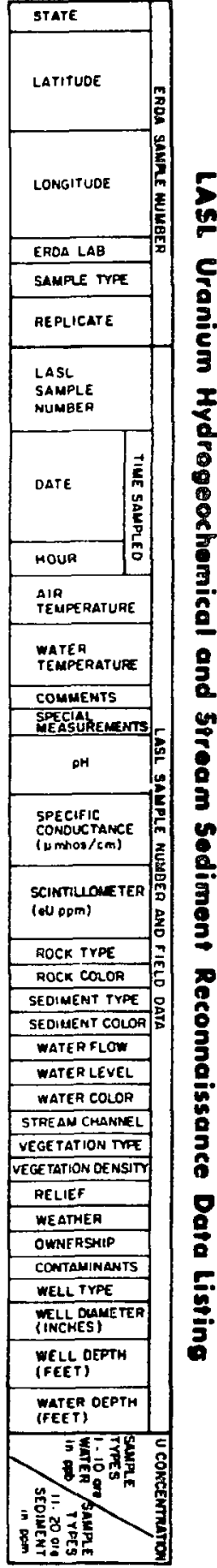




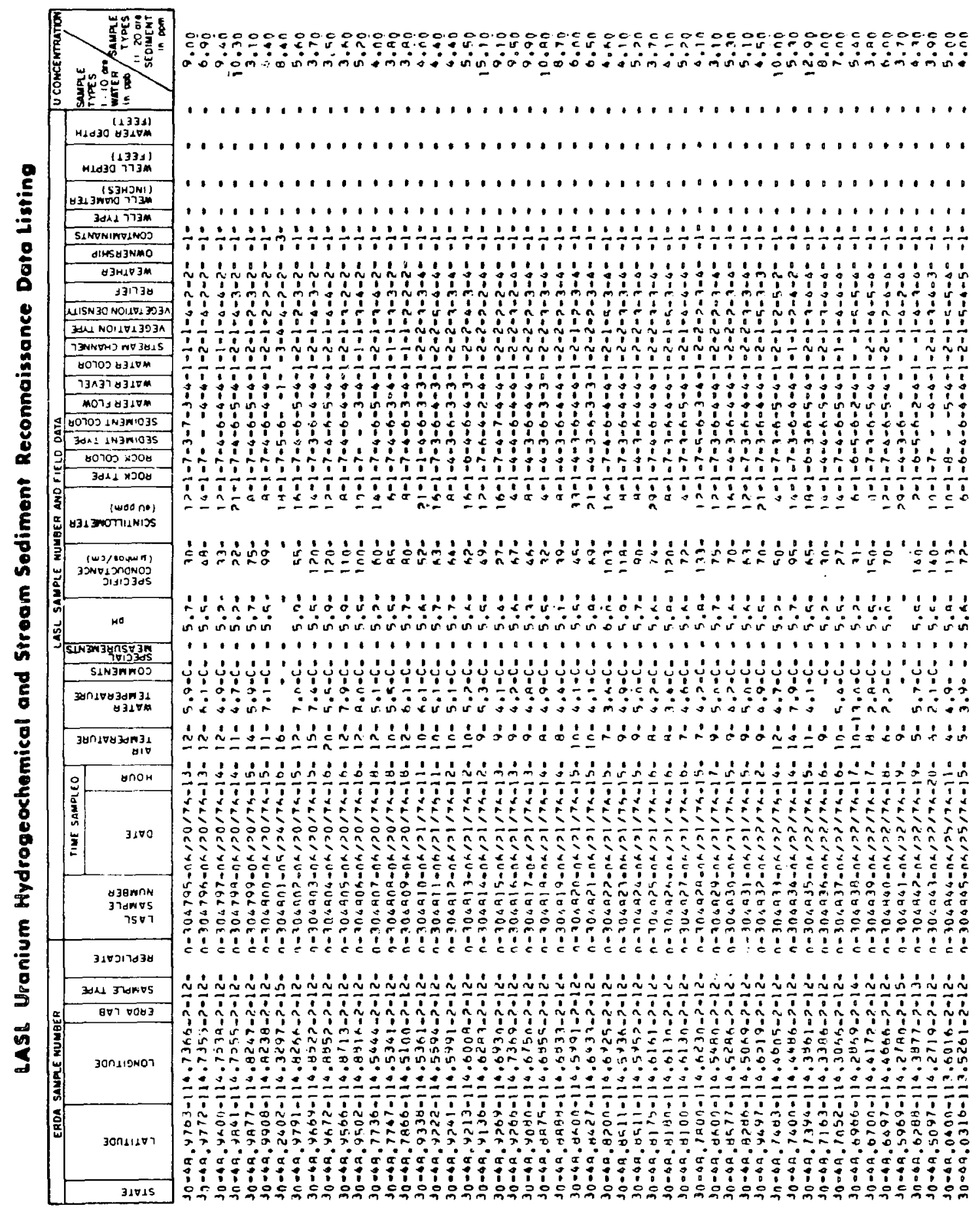




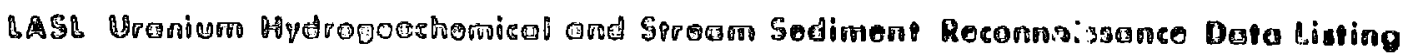

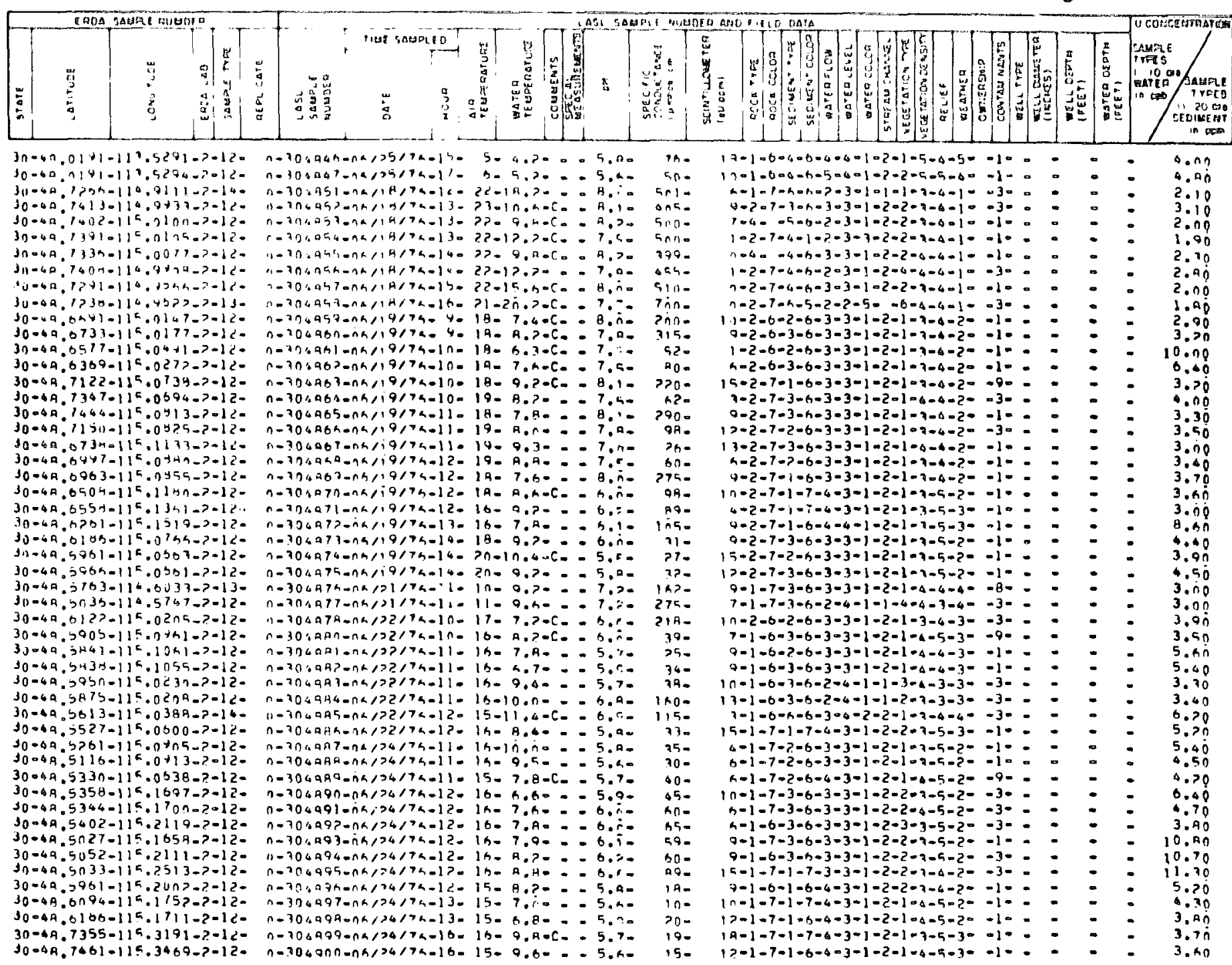


LASL Uronium Hydrogeochemical and Stream Sediment Reconnaissance Data Listing

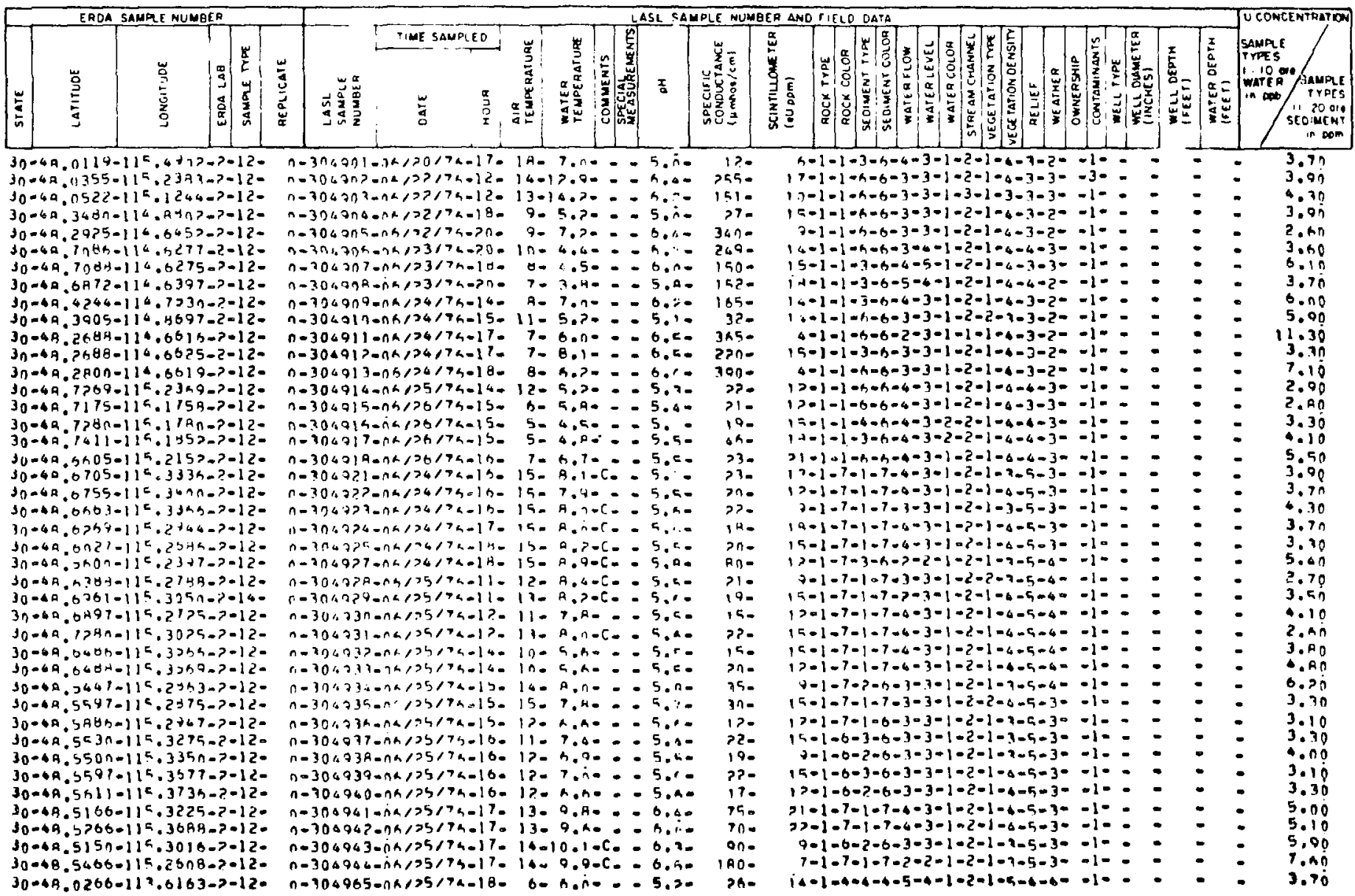


APPENDIX E

CODE TO DATA LISTINGS AND SAMPLE TYPES USED

BY

THE LOS ALAMCS SCIENTIFIC LABORATORY

IN THE

NURE HYDROGEOCHEMICAL AND STREAM SEDIMENT RECONNAISSANCE

ITEYI E-I

EXPLANATION OF CODE USED IN LASL HSSR DATA LISTINGS

(PATES E-1 THROUGH E-5)

ITEM E-II
NUMERICAL KEY AND SPECIFICATIONS
FOR SAMPLE TYPES TAKEN BY THE LASL

(PAGE E-6) 


\title{
APPENDIX ITEM I
}

\author{
EXPLANATION OF CODE USED \\ IN OPEN-FILE LISTINGS OF \\ HYDROGEOCHEMICAL AND STREAM SEDIMENT RECONNAISSANCE DATA \\ PROVIDED BY
}

THE LOS ALAMOS SCIENTIEIC LABORATORY

ERDA SAMPLE NUMBER

STATE: A two-digit Federal Information Processing Standards (FIPS) code, designating the state from which each sample came. For the states being covered by the LASL, the code numbers are:

$\begin{array}{ll}\text { Alaska }=02 & \text { New Mexico }=35 \\ \text { Colorado }=08 & \text { Wyoming }=56\end{array}$

LATITUDE AND LONGITUDE: Sample location, in degrees and decimal degrees to four places. However, though zenerally much better, locational accuracy cannot be guaranteed closer than about $300 \mathrm{~m}$ (1000 ft).

ERDA LAB: An Energy Research and Development Administration (ERDA) one-digit identifier designating the national laboratory responsible for taking the sample and the data shown in the listing, as well as providing the analysis giving the uranium and other elemental concentrations, if any. The LASL is designated by the numeral 2 .

SAMPLE TYPE: A two-digit identifier which specifically designates the pertinent proparties defining the sample type to which the listed data relate. For explanation of the code used, refer to the attached "Numerical Key and Specifications for Sample Types Taken by the LASL."

REPLICATE: A three-digit sequential number assigned to indicate a multiple sample of a single sample type from a single location. The largest number in use indicates the most recent sample taken, and there will always be smaller sequential numbers representing earlier samples back to 000 , which is the initial sample from any given location. Except in the case of special studies, there will be no replicate samples and this entry will therefore be 000 .

\section{LASL SAMPLE NUMBER AND FIELD DATA}

LASL SAMPLE NUMBER: A unique six-digit number permanently assigned by the LASL to every location sampled in each state. For internal use, these numbers are assigned in blocks to the various areas individually treated and reported upon, and therefore serve to generally locate the samples within the various states as follows.

Location Numbers

State

from 000001 through 099999

from 100001 through 199999

from 200001 through 299999

from 300001 through 399999

from 400001 through and above

$\begin{aligned} & \text { State } \\ = & \text { New Mexico } \\ = & \text { Colorado } \\ = & \text { Wyoming } \\ = & \text { Montana } \\ = & \text { Alaska }\end{aligned}$


TIME SAMPLED: The DATE that the sample was taken, in terms of the number of the MONTH, followed by the DAY and finally the YEAR, separated by slashes, and then the TIME it was taken on that data to the nearest whole HOUR on a military (24-hour) clock.

AIR TEMPERATURE: The temperature that was measured in the shade at the time of sampling, to the nearest whole degree Celsius $\left({ }^{\circ} \mathrm{C}\right)$.

WATER TEMPERATURE: The temperature that was measured in the sample water (in situ whenever possible) at the time of sampling, to the nearest one-tenth of a degree Celsius $\left(0.1^{\circ} \mathrm{C}\right)$.

COMMENTS: A "C" in this column indicates that some secondary comment not included in the listing was recorded at the sample location. This information will be used by the LASL in evaluating the data and, if appropriate, it will be mentioned in the final report.

SPECIAL MEASUREMENTS: An "S" in this column indicates that one or more field measurements in addition to those listed were made at the sample location. A description of any special parameters measured and the measured value at each sample location will be included in the final HSSR survey report on the area.

$\mathrm{pH}$ : The $\mathrm{pH}$, to the nearest one-tenth $(0.1)$ of a $\mathrm{pH}$ unit, that was measured in the water at the sample location at the time of sampling.

SPECIFIC CONDUCTANCE: The conductivity, in $\mu$ mhos $/ \mathrm{cm}$, that was measured in the water at the sample location at the time of sampling.

SCINTILLOMETER: The equivalent uranium ( $\mathrm{eU}$ ), in parts per million ( $\mathrm{ppm}$ ), as measured on a flat ground surface within $10 \mathrm{~m}$ of the sample location using a scintillometer fitted with a differential gamma sampler (DGS). The effect of the DGS is to introduce a fixed geometry into the measurement and remove the background.

ROCK TYPE: The single digit in this column provides a general description of the dominant lithologic regime at or near the sample location, as given below.

$$
\begin{array}{ll}
1=\text { Sedimentary } & 3=\text { Igneous } \\
2=\text { Metamorphic } & 4=\text { Unknown }
\end{array}
$$

KOCK COLOR: The single digit in this column provides an indication of the observed dominant color of local bedrock exposures at or near the sample location, as given below.

$$
\begin{array}{lll}
1=\text { White/Buff } & 4=\text { Pink/Red } & 7=\text { Gray } \\
2=\text { Yellow } & 5=\text { Green } & 8=\text { Black } \\
3=\text { Orange } & 6=\text { Brown } & 9=\text { Other }
\end{array}
$$

SEDIMENT TYPE: The single digit in this column provides a subjective evaluation of the dominant sediment type at the sample location, as given below.
$1=$ Boulders
4 = Sand
$7=$ Other
2 = Cobbles
$5=$ Mud
3 = Gravel
15 = Muck 
SEDIMENT COLOR: The single digit in this column indicates the observed dominant color of the bottom sediment (stream channel, lake bed, etc.) at the sample location at the time of sampling, as given below.

$$
\begin{array}{lll}
1=\text { White/Buff } & 4=\text { Pink/Red } & 7=\text { Gray } \\
2=\text { Yellow } & 5=\text { Green } & 8=\text { Black } \\
3=\text { Orange } & 6=\text { Brown } & 9=\text { Other }
\end{array}
$$

WATER FLOW: The single digit in this column provides a subjective evaluation of the wter movement at the sample location at the time of sampling, as given below.
1 = Stagnant
3 = Moderate
5 = Torrent
$2=$ Slow
4 = Fast

WATER LEVEL: The single digit in this column provides a subjective estimate of water quantity at the time of sampling, relative to its usual condition at the sample location, as given below.
$1=$ Dry
$3=$ Norinal
2 = Low
4 = High
5 Flood

WATER COLOR: The single digit in this column provides a subjective evaluation of suspended load in the sample water as, given below.
$1=\mathrm{Clear}$
2 = Murky
$3=$ Cloudy
$5=$ Algal
$6=$ Other

STREAM CHANNEL: The single digit here gives a subjective evaluation of stream channel character at the sample location at the time of sampling, as given below.

$$
1=\text { Depositing } \quad 2 \text { = Eroding } \quad 3 \text { = Unknown }
$$

VEGETATION TYPE: The single digit in this column provides a subjective evaluation of the dominant plant type in the vicinity of the sample location, according to the key below.
$1=$ Conifers
$4=$ Grass
$7=$ Other
2 = Deciduous
$5=$ Moss
3 = Brush
$6=$ Marsh

VEGETATION DENSITY: The single digit in this column provides a subjective estimate of the amount of plant cover in the vicinity of the sample location, according to the key below.
1 = Barren
$3=$ Moderate
$5=$ Very Dense
2 = Sparse
$4=$ Dense

RELIEF: The single digit in this column provides a subjective evaluation of the topography within a few hundred meters of the sample location, according to the key below.

$$
\begin{aligned}
& 1=\text { Flat } \\
& 2=\text { Low }(<15 \mathrm{~m})
\end{aligned}
$$

$3=$ Gentle $(15-60 \mathrm{~m})$

4 = Moderate $(60-300$
$5=\operatorname{High}(>300 \mathrm{~m})$

m) 6 - other 
WEATHER: The single digit in this column gives the observed climatic condition at the sample location at the time of sampling, as given by the key below.

$$
\begin{array}{lll}
1=\text { Clear } & 3=\text { Overcast } & 5=\text { Snowy } \\
2=\text { Partly cloudy } & 4=\text { Rainy } & 6=\text { Other }
\end{array}
$$

OWNERSHIP: The single digit here gives a broad classification of administrative responsibility or general ownership of the land at the sample location, according to the key below.
$1=$ Federal
3 = Private
$5=$ other
2 = State
4 = Indian

CONTAMINANTS: The single digit here indicates known or suspected local factors likely to influence analytical results, according to the key below.
$1=$ None
4 = Industry
$2=$ Mining
3 = Agriculture
5 = Sewage
7 = Urban
$6=$ Power generation
8 = Recreation
$9=$ other

WELL TYPE: The single digit in this column provides a general description of the type of water well from which the sample was taken (if, in fact, it was a well sample), according to the key below.
1 = Windmill-stock
4 = Suction pump
$7=$ Hand bail
2 = Windmill-domestic
$5=$ Jet pump
8 - Unknown
3 = Submersible pump
6 = Large turbine
$9=$ Other

WELL DIAMETER: The one or two digits (if any) in this column give the measured or estimated inside diameter, in inches, of the casing of the well from which the sample (if taken from a well) came.

WELL DEPTH: The one, two, or three digits (if any) in this column give the total drilled depth from the surface, in feet, of the well from which the sample: (if taken from a well) came. Three $9 \mathrm{~s}$ in this column indicates a well depth greater than $1000 \mathrm{ft}$.

WATER DEPTH: The one, two, or three digits in this column give the depth, in feet, from the surface to the standing water in the well, if known (if the sample was taken from a well). A - I in this column indicates a flowing artesian well.

URANIUM CONCENTRATION: The value given in this column is the analytically derived value of the uranium concentration found in the water sample in parts per billion (ppb), or in the sediment sample in parts per million ( $\mathrm{ppm}$ ).

Sample Types No. 1 through 10 and 21 through 30 are water samples, with their uranium concentrations given in ppb, w.ile Sample Types No. 11 through 20 and 31 through 40 are sediment samples, with their uranium concentration given in ppm. 


\title{
APPENDIX ITEM II
}

\author{
ABBREVIATED NUMERICAL KEY AND SPECIFICATIONS \\ FOR COMMON SAMPLE TYPES TAKEN BY \\ THE LOS ALAMOS SCIENTIFIC LABORATORY (LASL) \\ IN THE NATIONAL URANIUM RESOURCE EVALUATION (NURE) \\ HYDROGEOCHEMICAL AND STREAM SEDIMENT RECONNAISSANCE (HSSR)
}

This numerical key provides the necessary tie between the specific type or form of each sample taken in the LASL HSSR program and each individual suite of field and laboratory data to which the sample relates. It defines the various sample typei generally to be collected by the LASL in the ERDA HSSR for uranium.

The two-digit key number assigned to each sample type herein designates three distinct properties of the most common types of samples taken by the LASL in the NURE HSSR project. These properties are: (a) The general sample source (spring or stream or dry stream, etc.); (b) The sample medium (water or sediment, etc.); and (c) The treatment given the sample in the field or laboratory prior to its analysis by the LASL.

The key numbers are inserted in the appropriate columns of the specially formatted ERDA sample numbering system to positively identify the sample type for all LASL sample data submitted. An expanded version of this key, which includes sample types less commonly used by the LASL, will be provided whenever data from such samples are submitted.

\section{KEY NO. $\quad$ SOURCE / MEDIUM / TREATMENT}

01 - Spring water sample untreated.

02 - Stream water sample untreated.

03 - Well water sample untreated.

04 - Natural pond water sample untreated.

05 - Artifinial pond water sample untreated.

06 - Spring water sample filtered thrcugh an $0.45-\mu$ membrane filter and acidified to a $\mathrm{pH}$ of $\leq 1$ with reagent-grade nitric acid ( $\mathrm{HNO}_{3}$ ).

07 - Stream water sample filtered through an $0.45-\mu$ membrane filter and acidified to a $\mathrm{pH}$ of $\leq 1$ with reagent-grade nitric acid ( $\mathrm{HNO}_{3}$ ).

08 - Hell water sample filtered through an $0.45-\mu$ membrane filter and acidified to a $\mathrm{pH}$ of $\leq 1$ with reagent-grade nitric acid ( $\mathrm{HNO}_{3}$ ).

09 - Natural pond water sample filtered through an $0.45-\mu$ membrane filter and acidified to a $\mathrm{pH}$ of $\leq 1$ with reagent-grade nitric acid ( $\mathrm{HNO}_{3}$ ).

10 - Artificial pond water sample filtered through an $0.45-1$ membrane filter and acidified to a $\mathrm{pH}$ of $\leq \lambda$ with reagent-grade nitric acid ( $\mathrm{HNO}_{3}$ ). 
11 - Wet spring sediment sample dried at $\leq 100^{\circ} \mathrm{C}$ and sieved to -100 mesh through stainless steel sieves.

12 - Wet stream sediment sample dried at $\leq 100^{\circ} \mathrm{C}$ and sieved to $=100$ mesh through stainless steel sieves.

13 - Wet natural pond sediment sample dried at $\leq 100^{\circ} \mathrm{C}$ and sieved to -100 mesh through stainless steel sieves.

14 - Wet artificial pond sediment sample dried at $\leq 100^{\circ} \mathrm{C}$ and sieved to -100 mesh through stainless steel sieves.

15 - Dry stream sediment sample dried at $\leq 100^{\circ} \mathrm{C}$ (if necessary) and sieved to -100 mesh through stainless steel sieves.

96 - Dry natural pond sediment sample dried at $\leq 100^{\circ} \mathrm{C}$ (if necessary) and sieved to -100 mesh through stainless steel sieves.

97 - Dry artificial pond sediment sample dried at $\leq 100^{\circ} \mathrm{C}$ (if necessary) and sieved to -100 mesh through stainless steel sieves.

98 - Other water

99 - Other sediment
These key numbers are to be used only for water (98) or sediment (99) samples coming from a special source and/ or given a special treatment not described for any of the types of samples above. When used in the listings published herein, the source and treatment given the samples so designated are described in the text. 


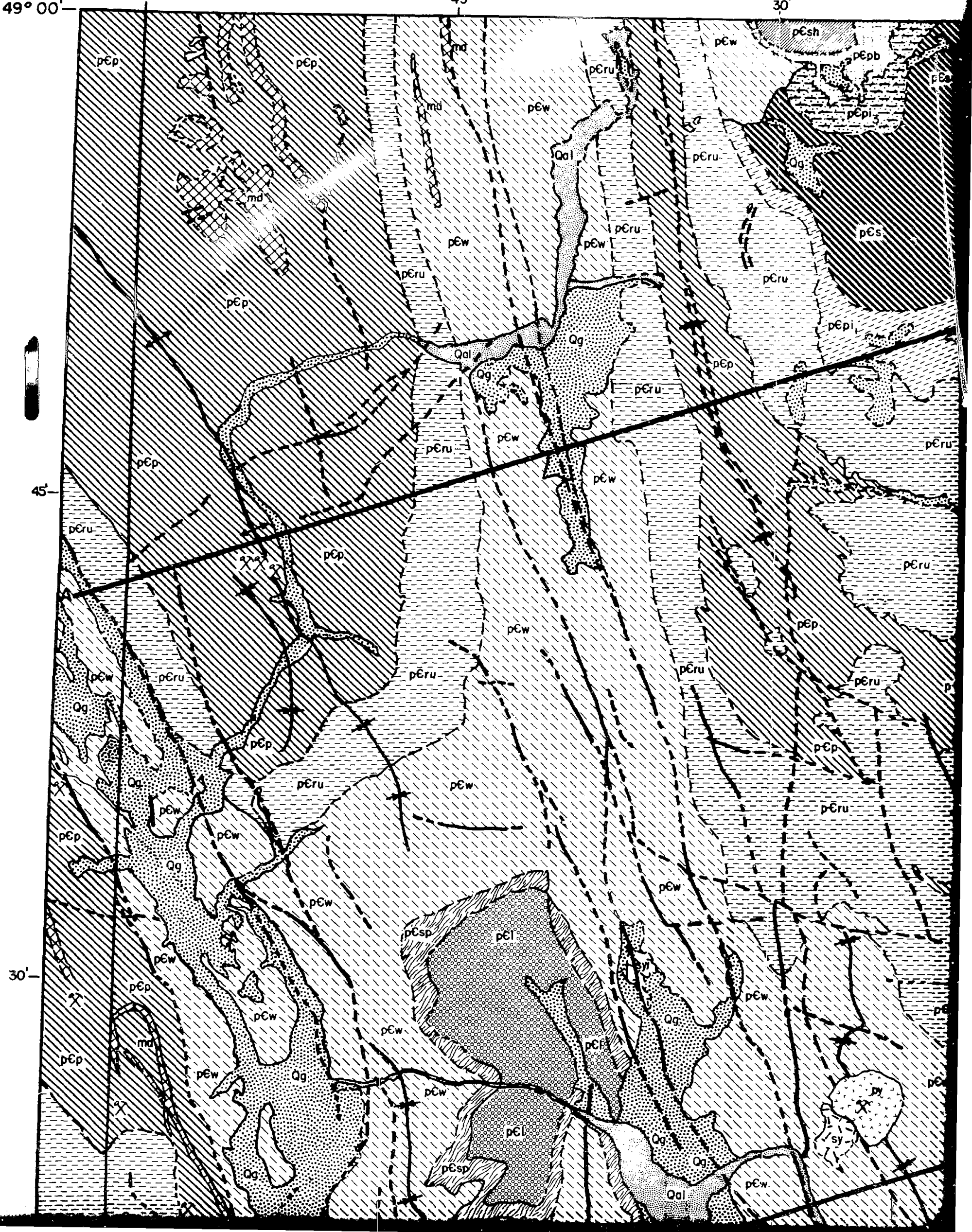




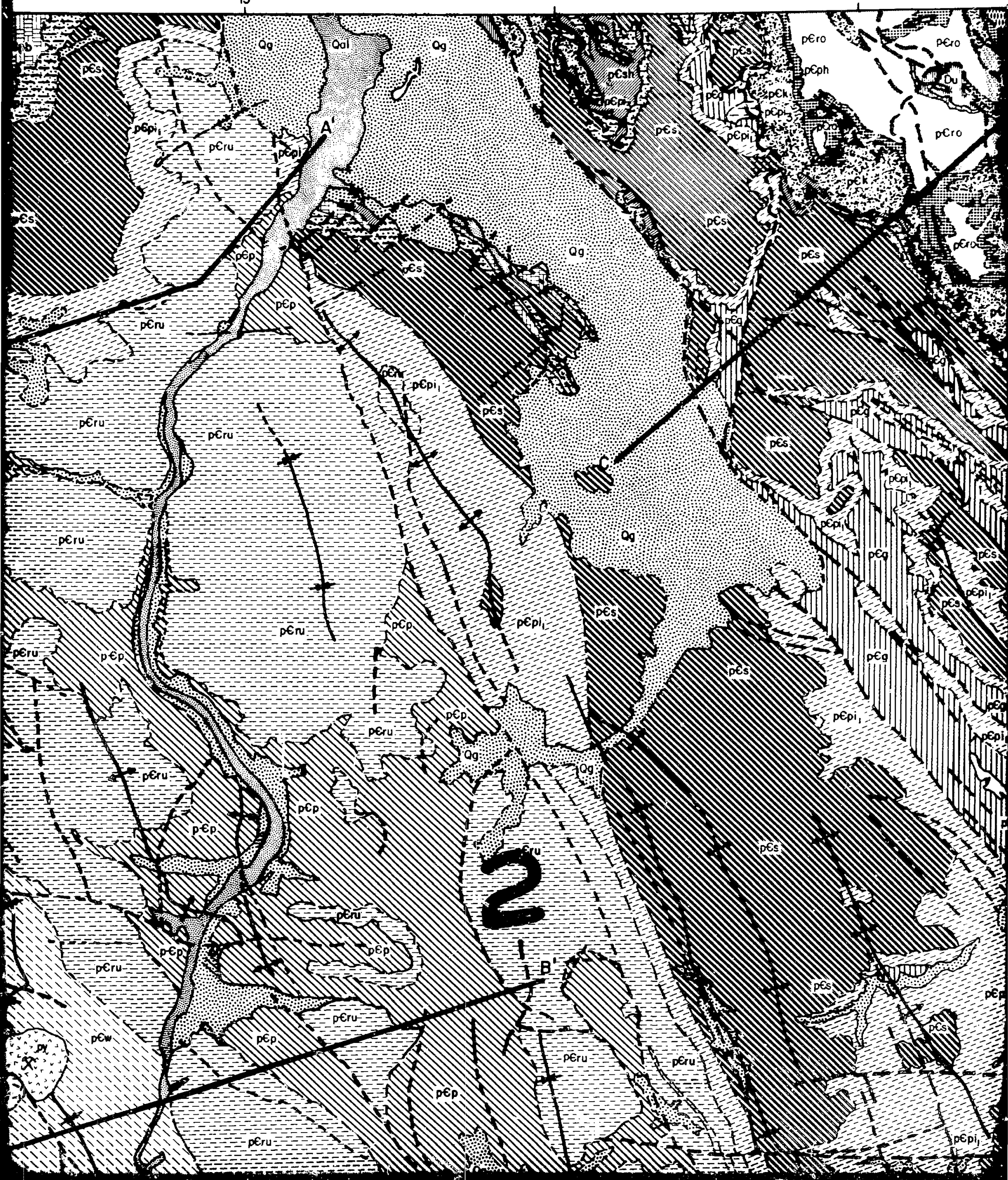




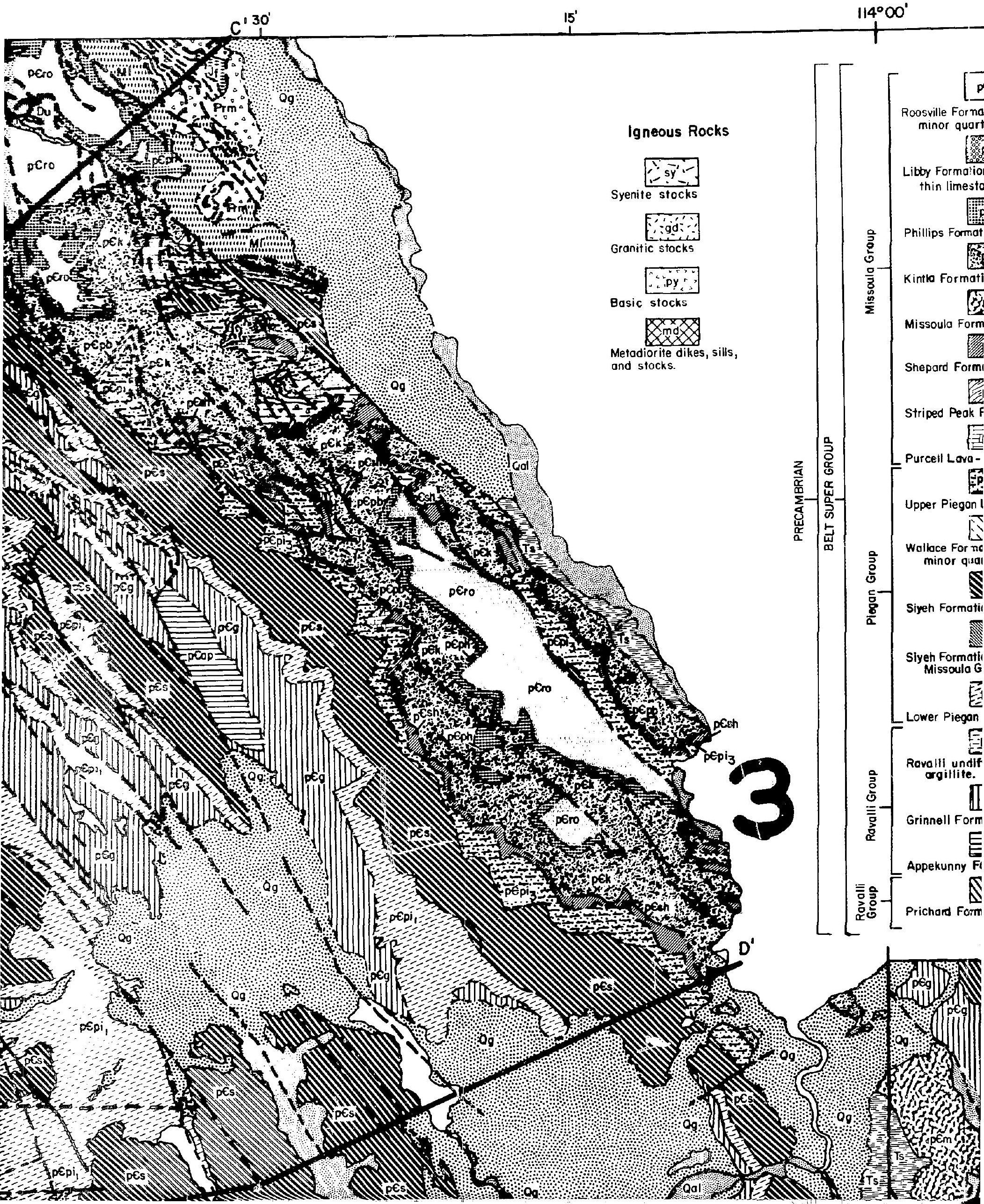




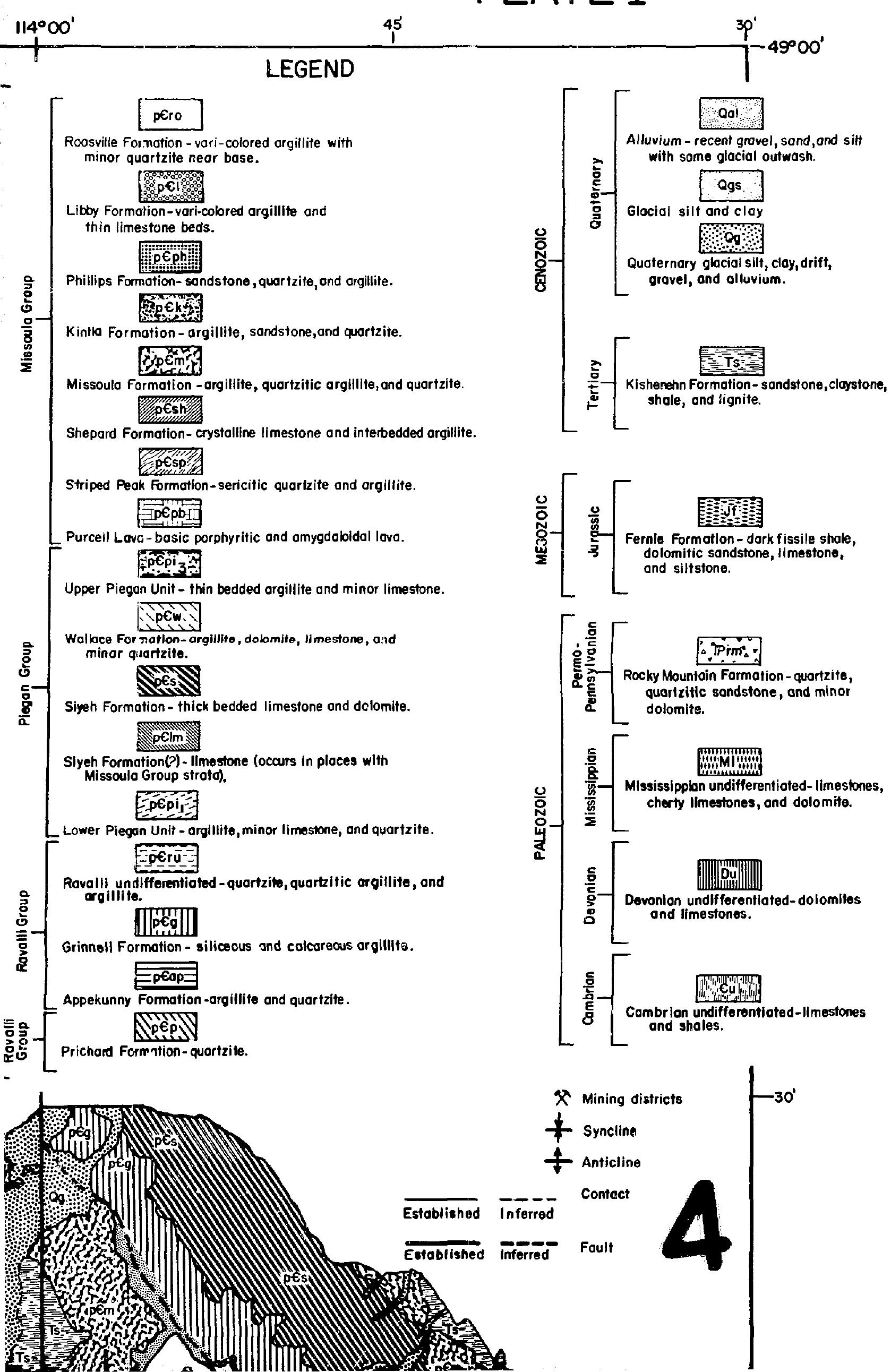




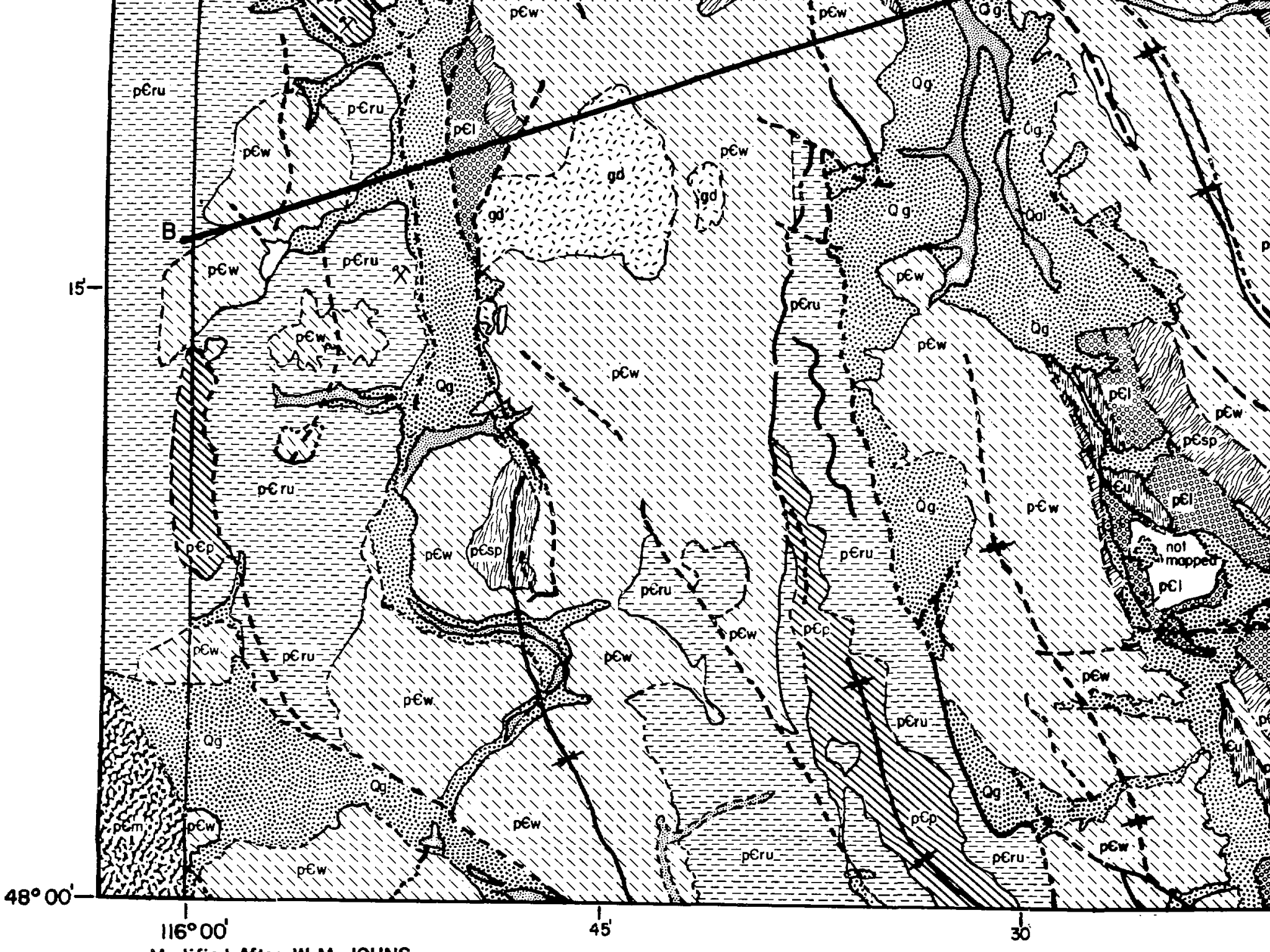

Modified After W. M. JOHNS

and others

(1970)
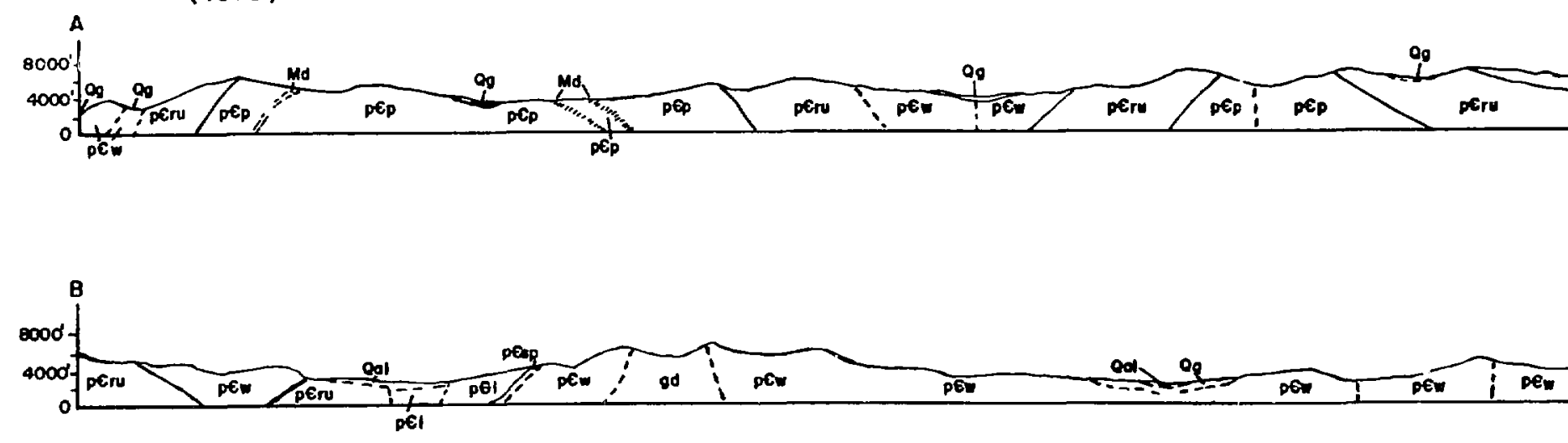


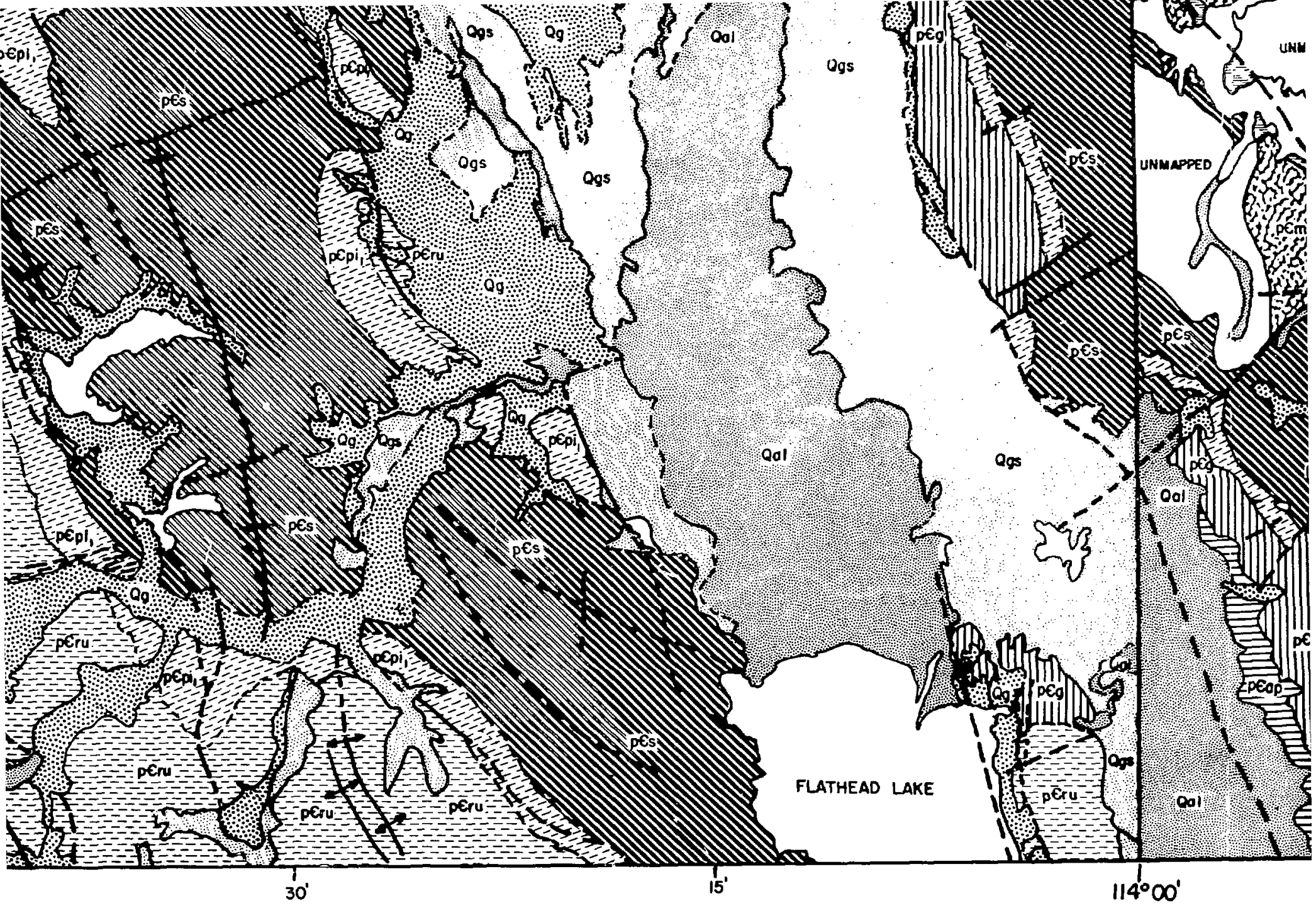

(1)

SCALE I: 250 (

$\begin{array}{lllll}5 & 0 & 5 & 10 \\ 5 & 0 & 5 & 10 \\ 5\end{array}$

:

\section{ILOGY}

THEAD COUNTIES)

TANA 


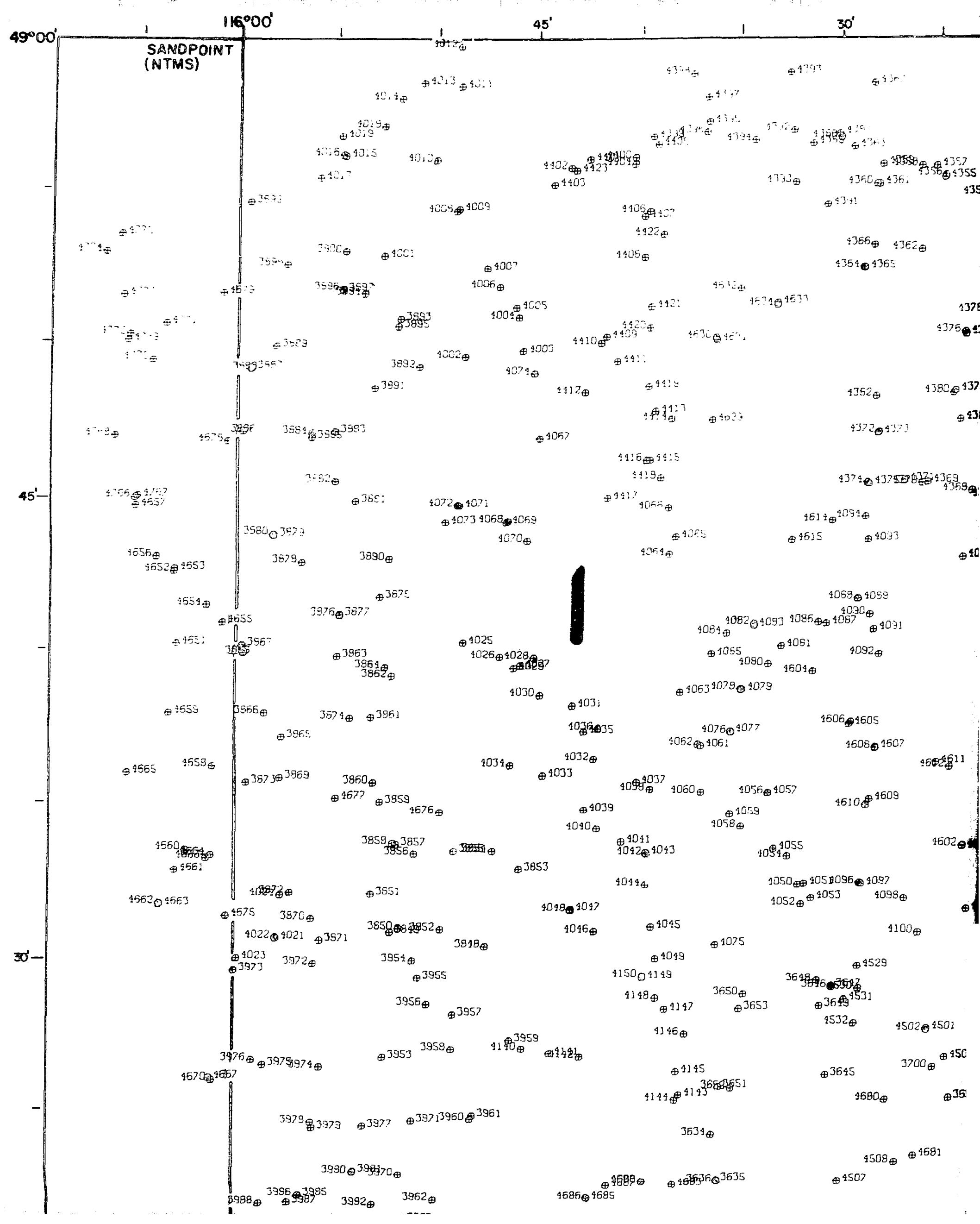




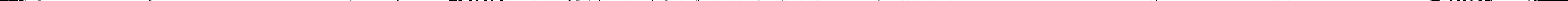




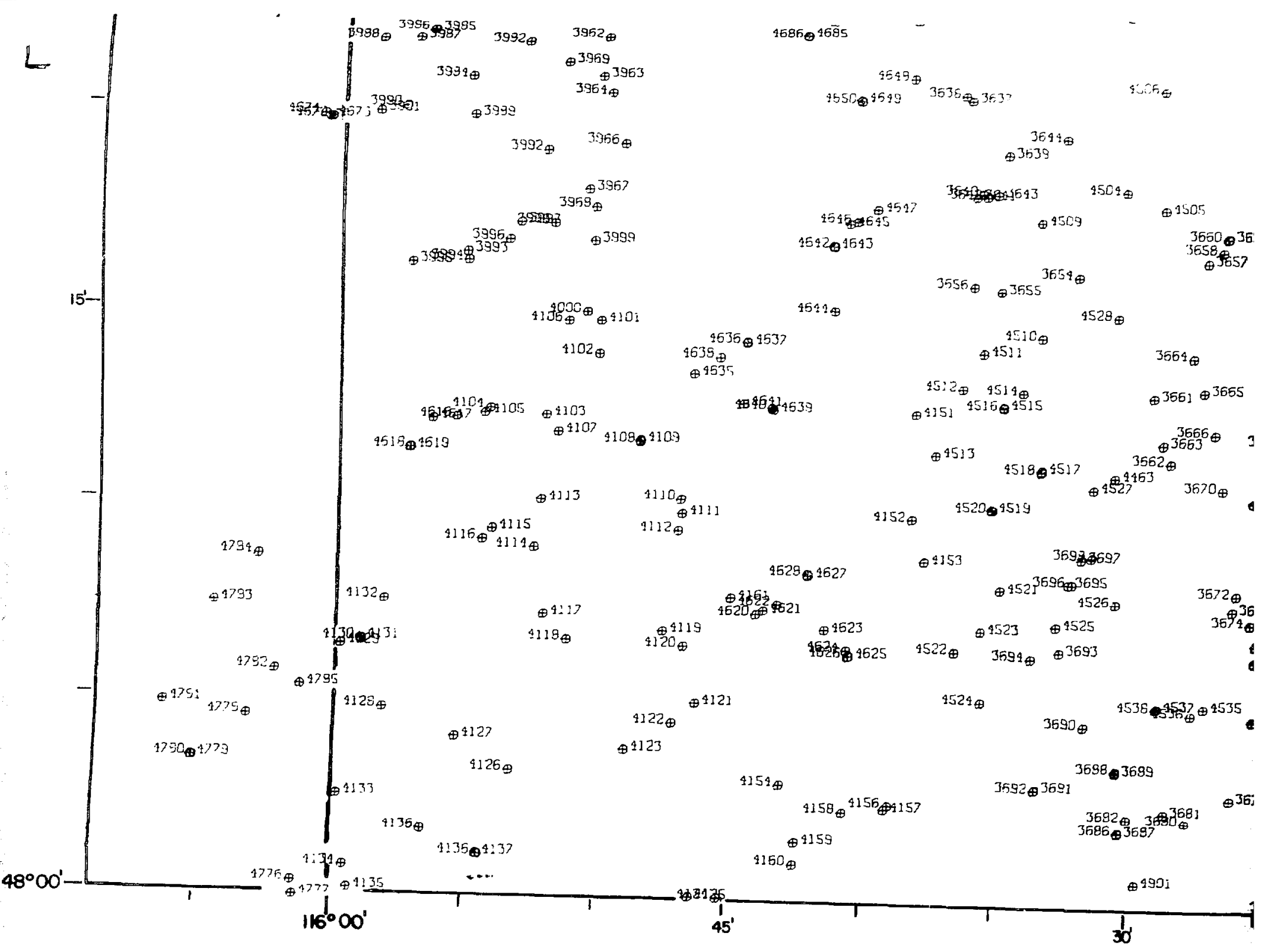




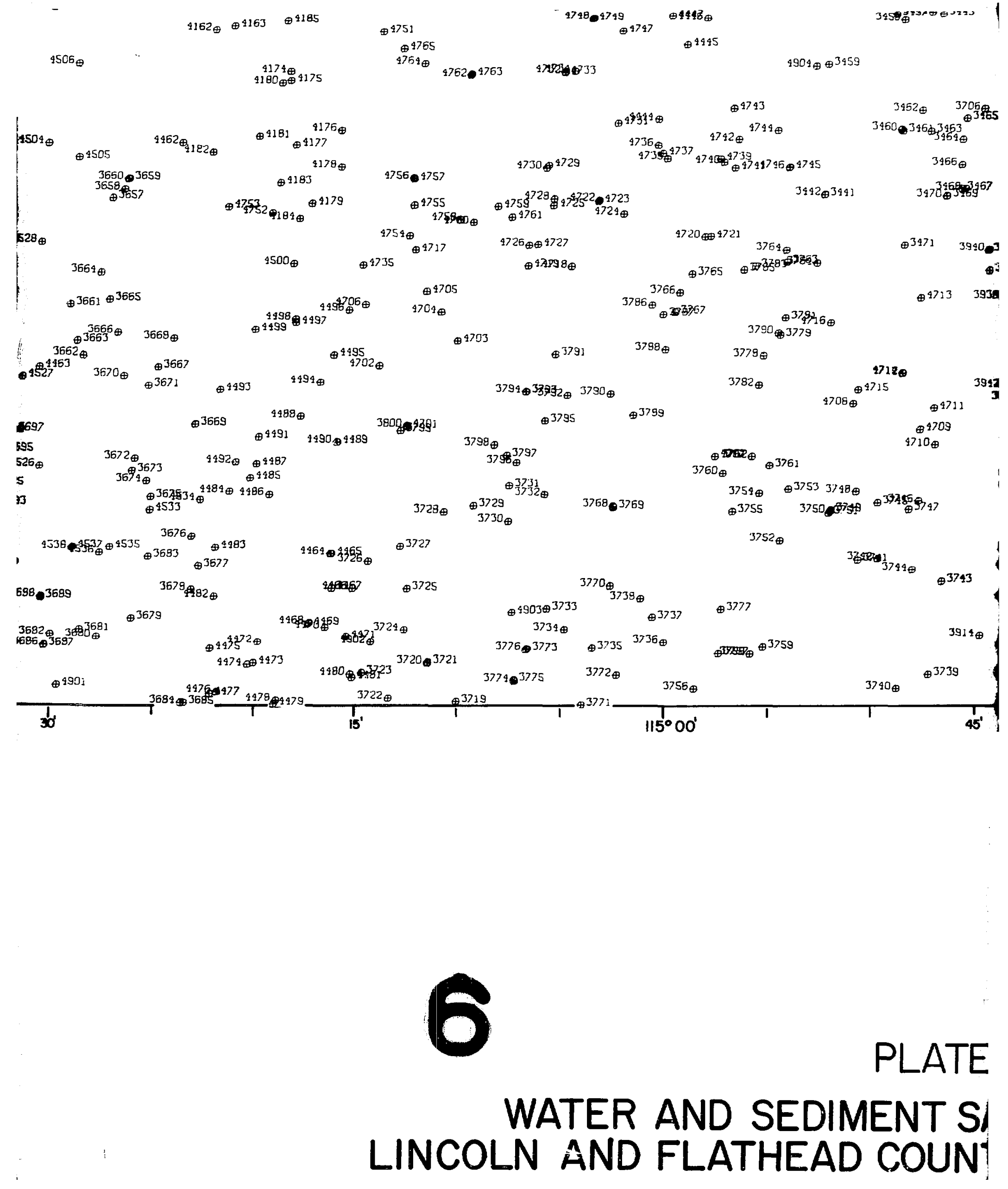




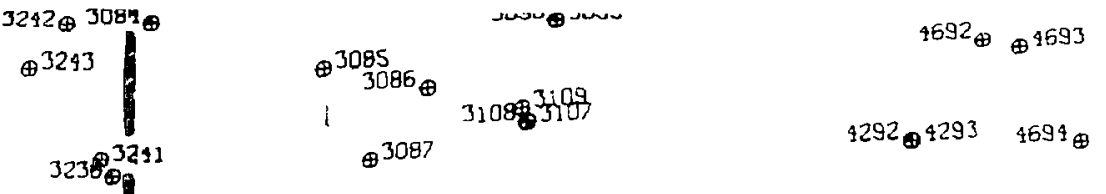

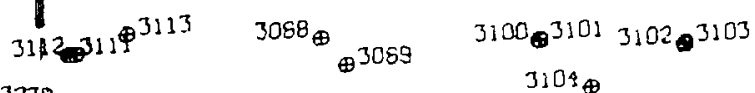

$$
{ }_{323 \theta^{324037}}^{3239} 4518_{\oplus}^{3116^{9}} \oplus^{315} \oplus^{3117}
$$

$$
\mid \begin{array}{ll}
3533 \\
33513517 \\
3330_{\oplus}
\end{array}
$$$$
\text { 甲3325 }
$$$$
3323 \quad 33256^{3328} 3423
$$$$
322 \oplus
$$$$
\text { @3335 }
$$

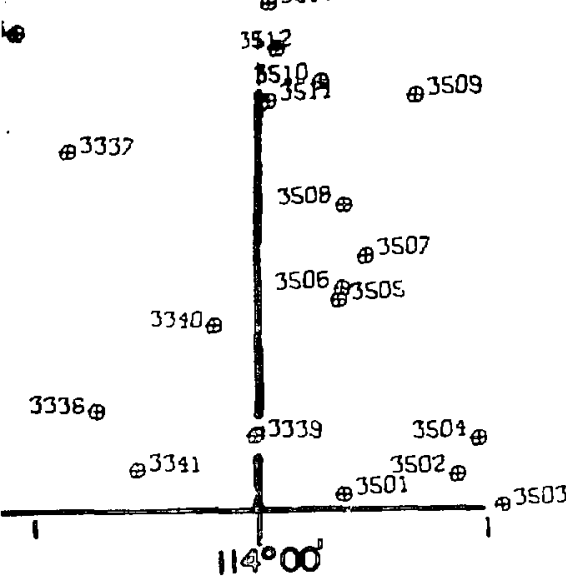

$$
3110_{\oplus}
$$

$3520 \oplus$$$
\oplus^{3519} \quad 3120_{\oplus}^{3115} \quad \oplus^{3413}
$$$$
63105
$$$$
3522 \oplus^{3121}
$$$$
3529^{\oplus}
$$$$
3 i 22 \oplus \quad 3914 \oplus
$$$$
3124 \oplus^{3123} 306 \oplus^{3415}
$$$$
4595 \oplus^{4697}
$$

$$
4700_{\oplus}^{4599} 9599
$$$$
1290_{\oplus}
$$

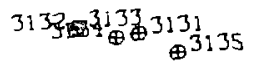

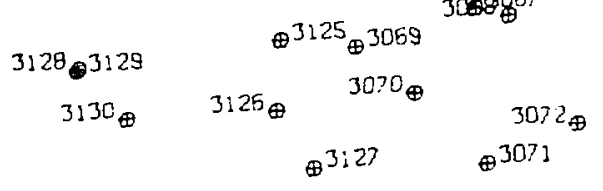

$$
\begin{aligned}
& \oplus^{3073}
\end{aligned}
$$

$$
3 i 463^{3135} \sin ^{3 i 43} \oplus^{3075}
$$

$$
3140,3139
$$

$$
\begin{aligned}
& 3524 \oplus \\
& 3902 \oplus \oplus^{3197} \oplus^{35227}
\end{aligned}
$$

$3412 \oplus$

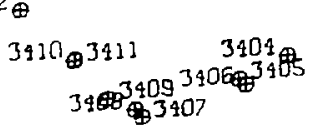

$\oplus^{3403}$

$\oplus^{4955}$

$\oplus^{4845}$

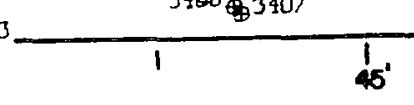
$3150 \div 340$ $484 E_{\oplus}^{4847}$

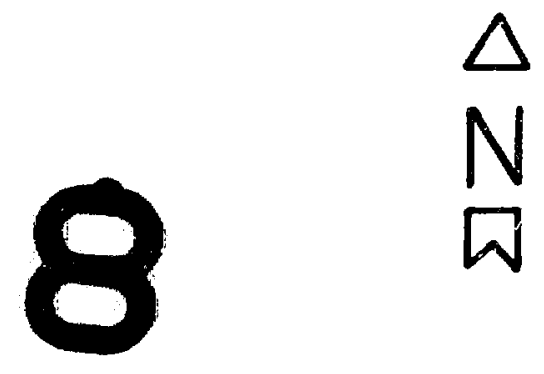




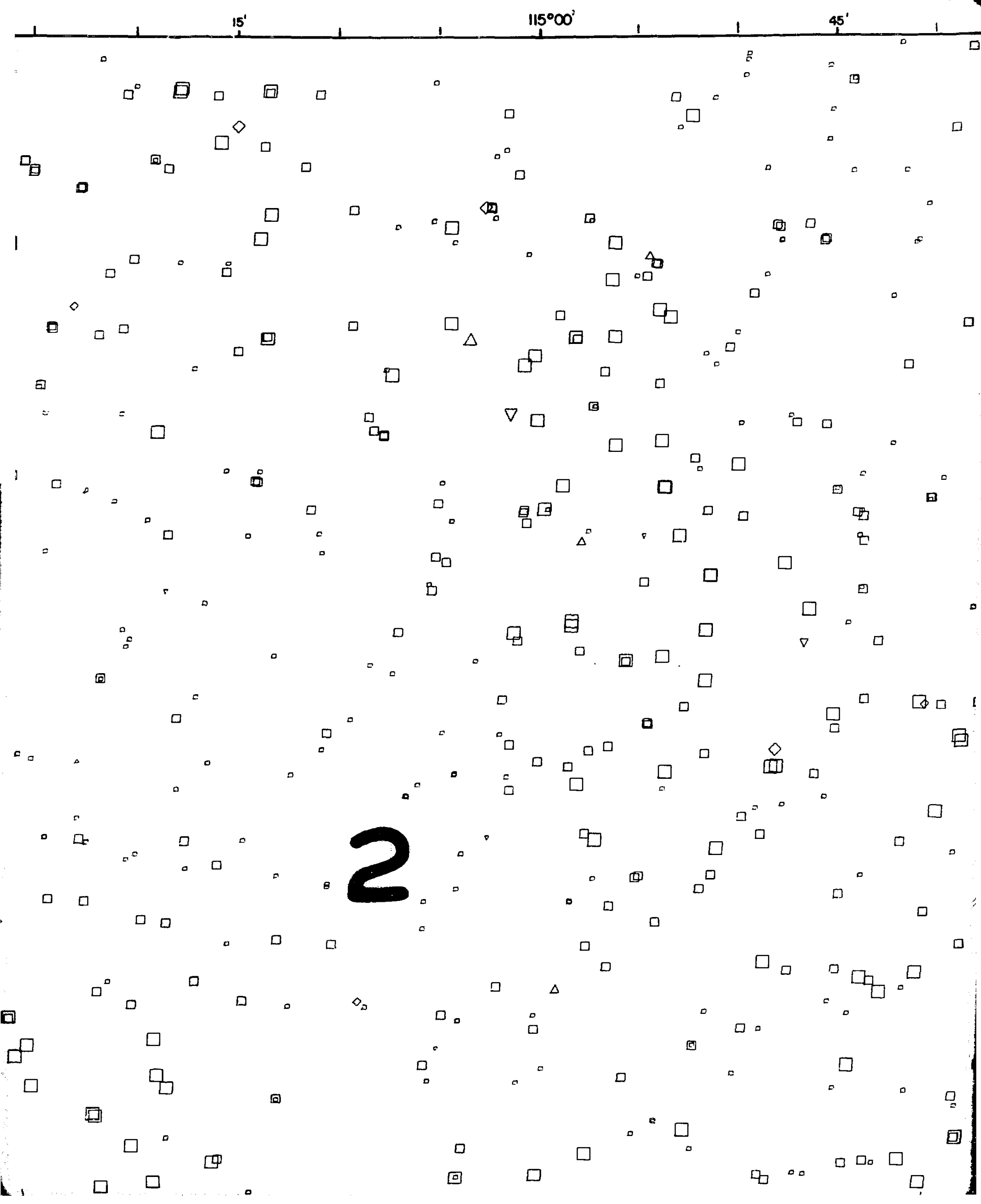




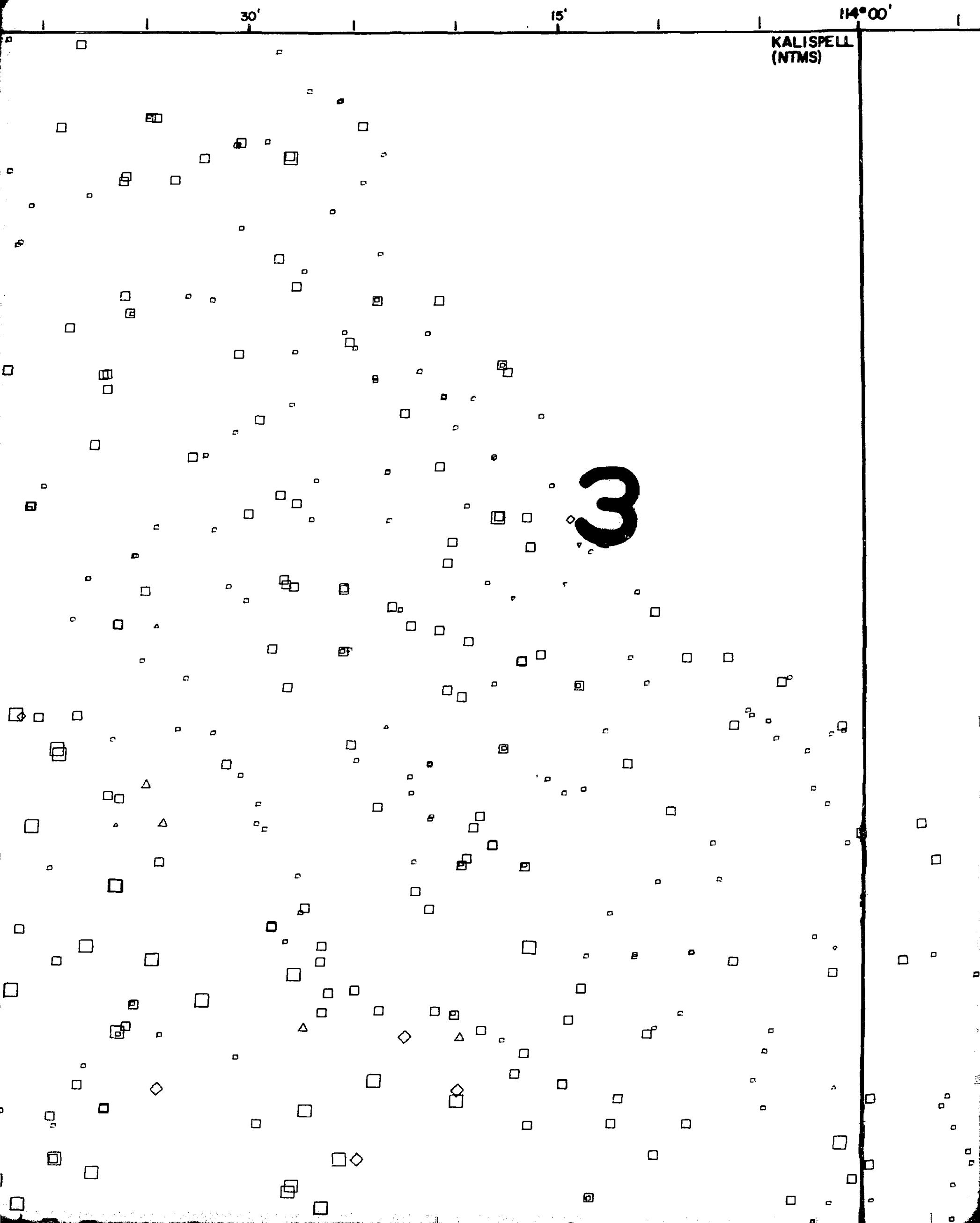


PLATE III

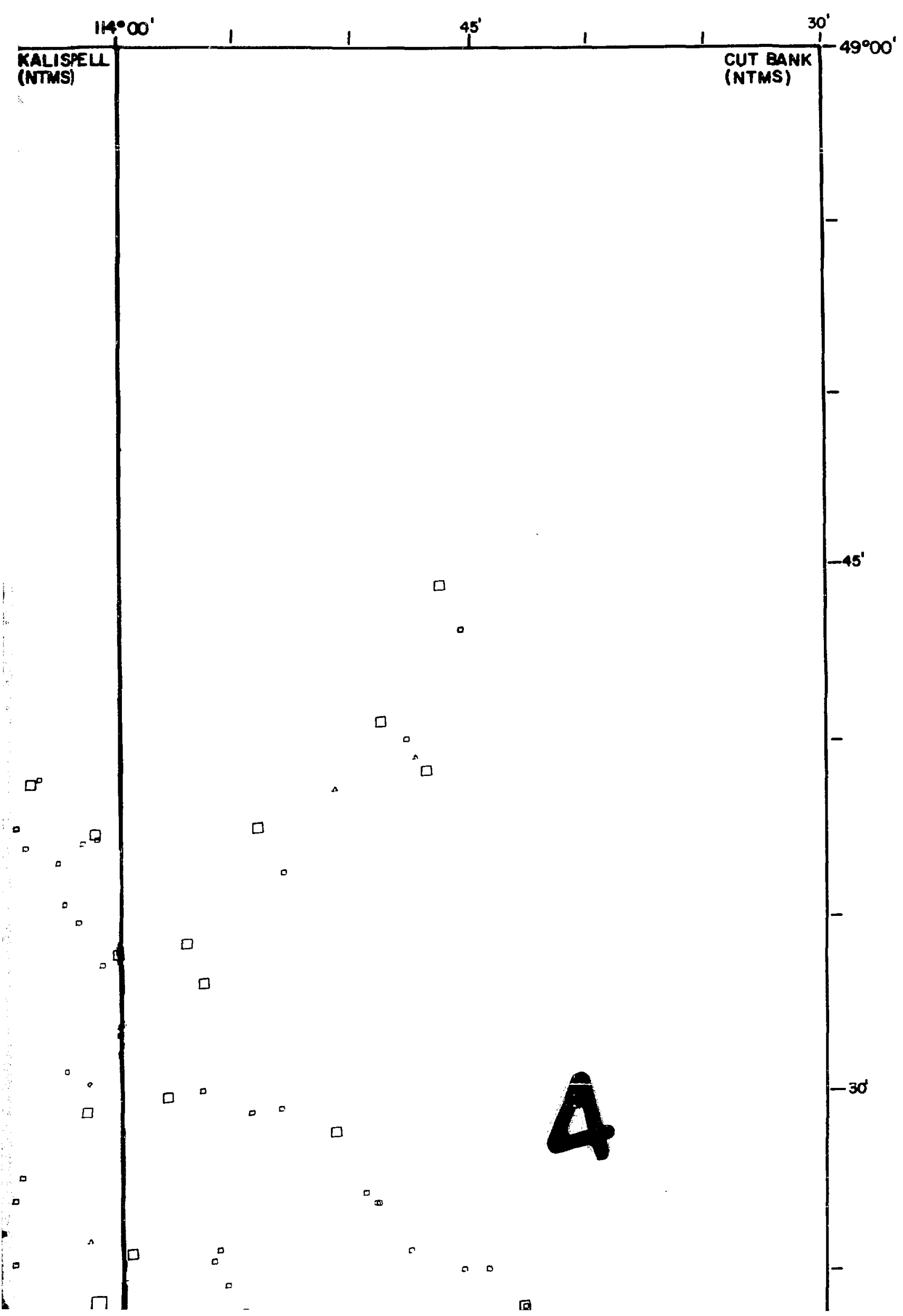




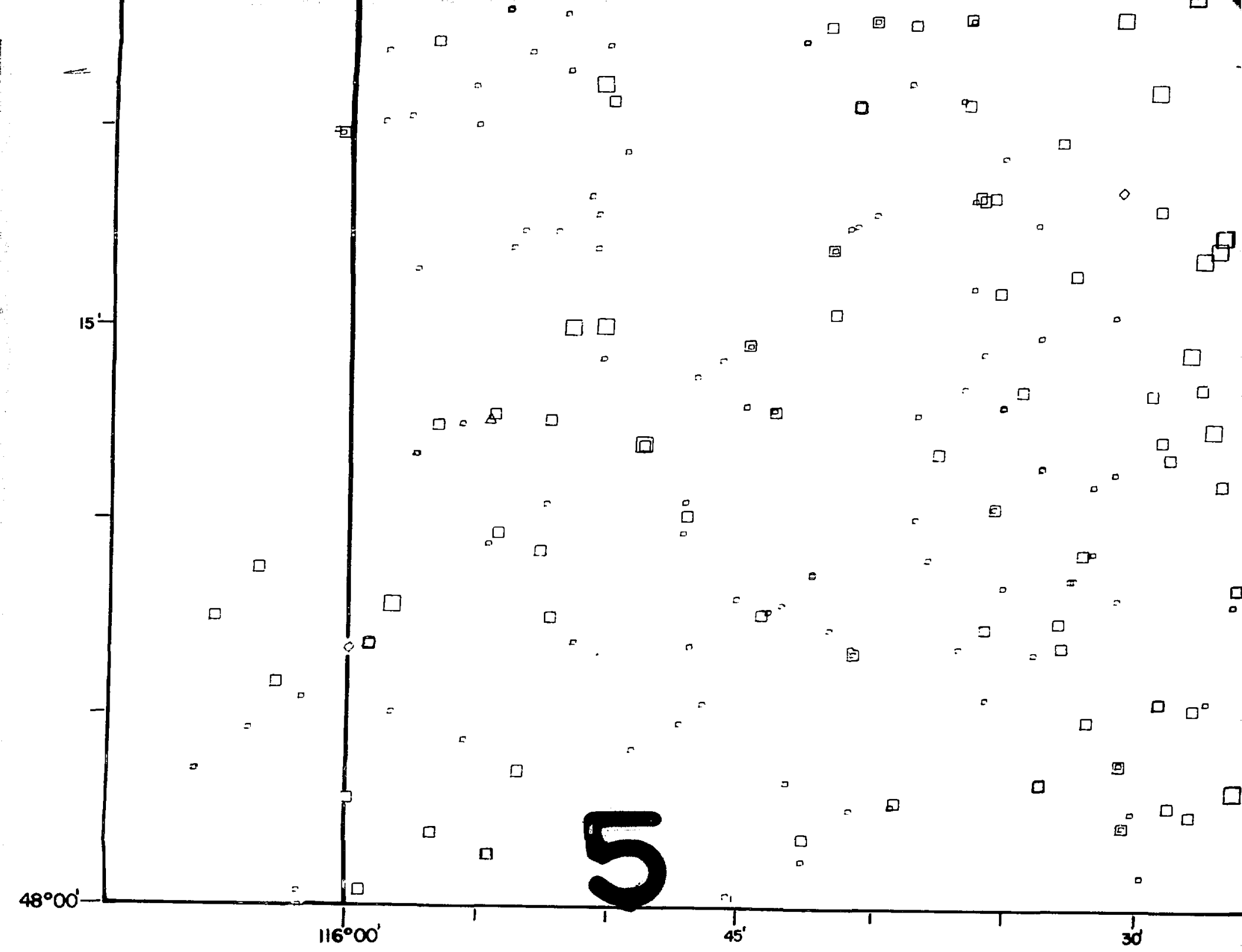

LEGEND

\begin{tabular}{|c|c|c|c|c|c|}
\hline & & & & & 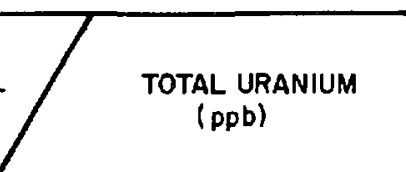 \\
\hline ○ & • & 0 & $\Delta$ & 0 & [<LOWER DETECTION LIMIT] \\
\hline 0 & $\diamond$ & $\nabla$ & $\Delta$ & $\square$ & $\begin{array}{l}0.20-0.66 \\
(0.20 \text { to M) }\end{array}$ \\
\hline O & $\diamond$ & $\nabla$ & $\Delta$ & $\square$ & $\begin{array}{l}0.66 \overrightarrow{5} 5.19 \\
0 M \text { to }(M+1 \sigma)]\end{array}$ \\
\hline 0 & $\diamond$ & $\nabla$ & $\Delta$ & $\square$ & $\begin{array}{c}5.19-7.46 \\
[M+1 \sigma)+10(M+1.5 \sigma)]\end{array}$ \\
\hline 0 & $\diamond$ & $\nabla$ & $\triangle$ & $\square$ & $\begin{array}{l}7.46 \cdot 9.72 \\
{[(M+1.5 \sigma) \text { to }(M+2 \sigma)]}\end{array}$ \\
\hline 0 & $\diamond$ & $\nabla$ & $\triangle$ & $\square$ & $\begin{array}{c}9.72 \rightarrow 11.59 \\
{[(M+2 \sigma) \text { io }(M+25 \sigma]}\end{array}$ \\
\hline 0 & $\diamond$ & $\nabla$ & $\triangle$ & & $\begin{array}{c}11.99-14.25 \\
{[(M+2.5 \sigma)+0(M+3 \sigma)]}\end{array}$ \\
\hline ( & $\widehat{\rangle}$ & $\bar{\nabla}$ & $\triangle$ & & $\begin{array}{l}>14.25 \\
{[>(M+3 \sigma)]}\end{array}$ \\
\hline
\end{tabular}

NOTE:

$M=0.66 \mathrm{ppD}=\mathrm{MEN}$ y YNUE FOR AL WATER SAMFL
COMBINED.

$(\sigma)$ STANDARD DEVIATION $=4.53$

SAMPLES $\leq 10 \mathrm{pDb}$ WERE ANALYZE BY FLUOROMETRY, SAMPLES > 10 WERE ANALYZED BY DELAYED NEUTRON COUNTING. 
Ta

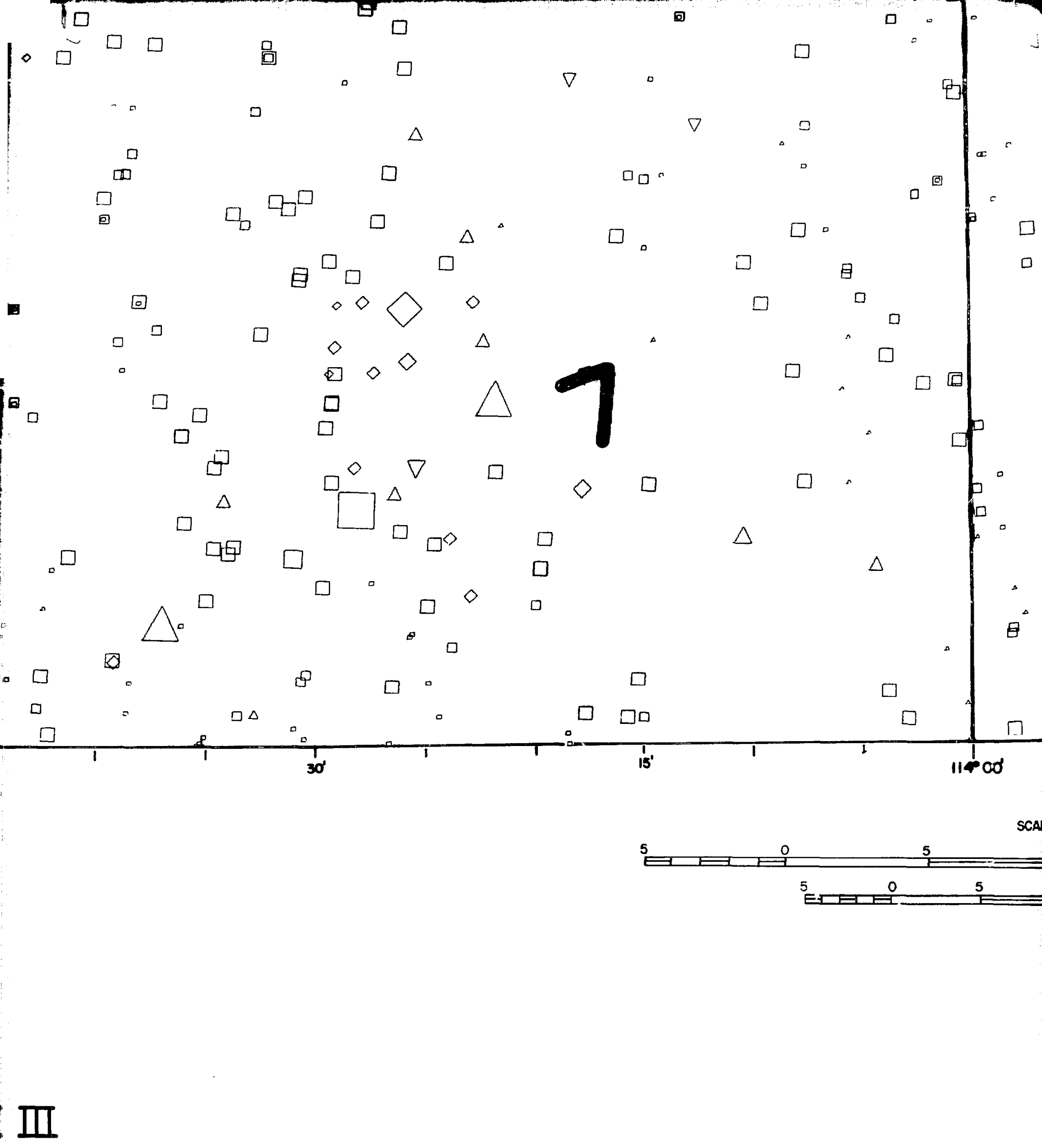




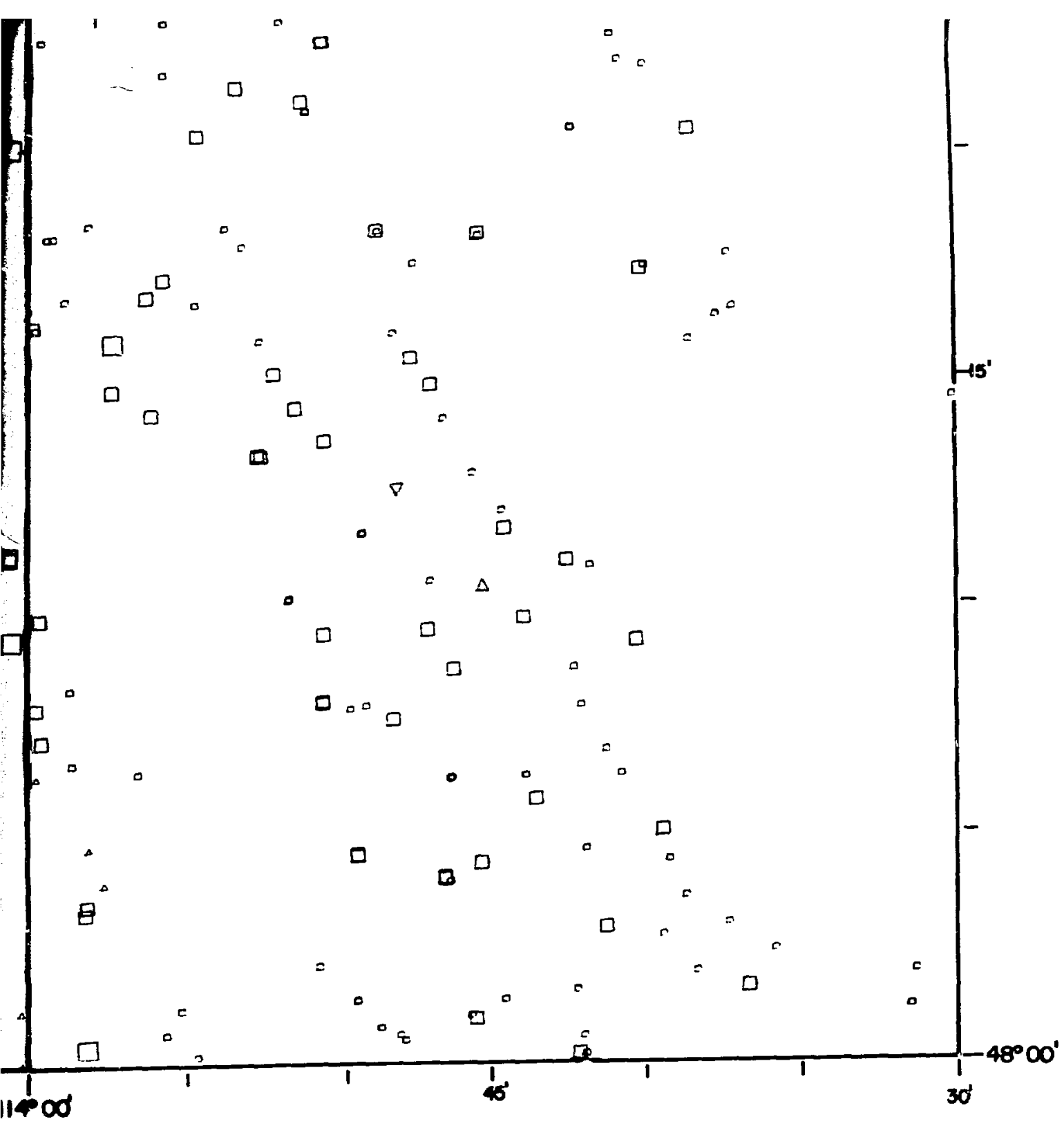

SCALE : 250000

5 $10 \quad 15$ 25 KILOMETERS
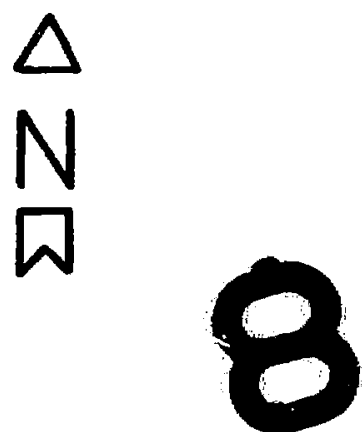


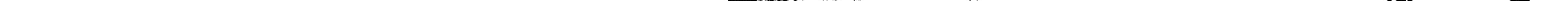




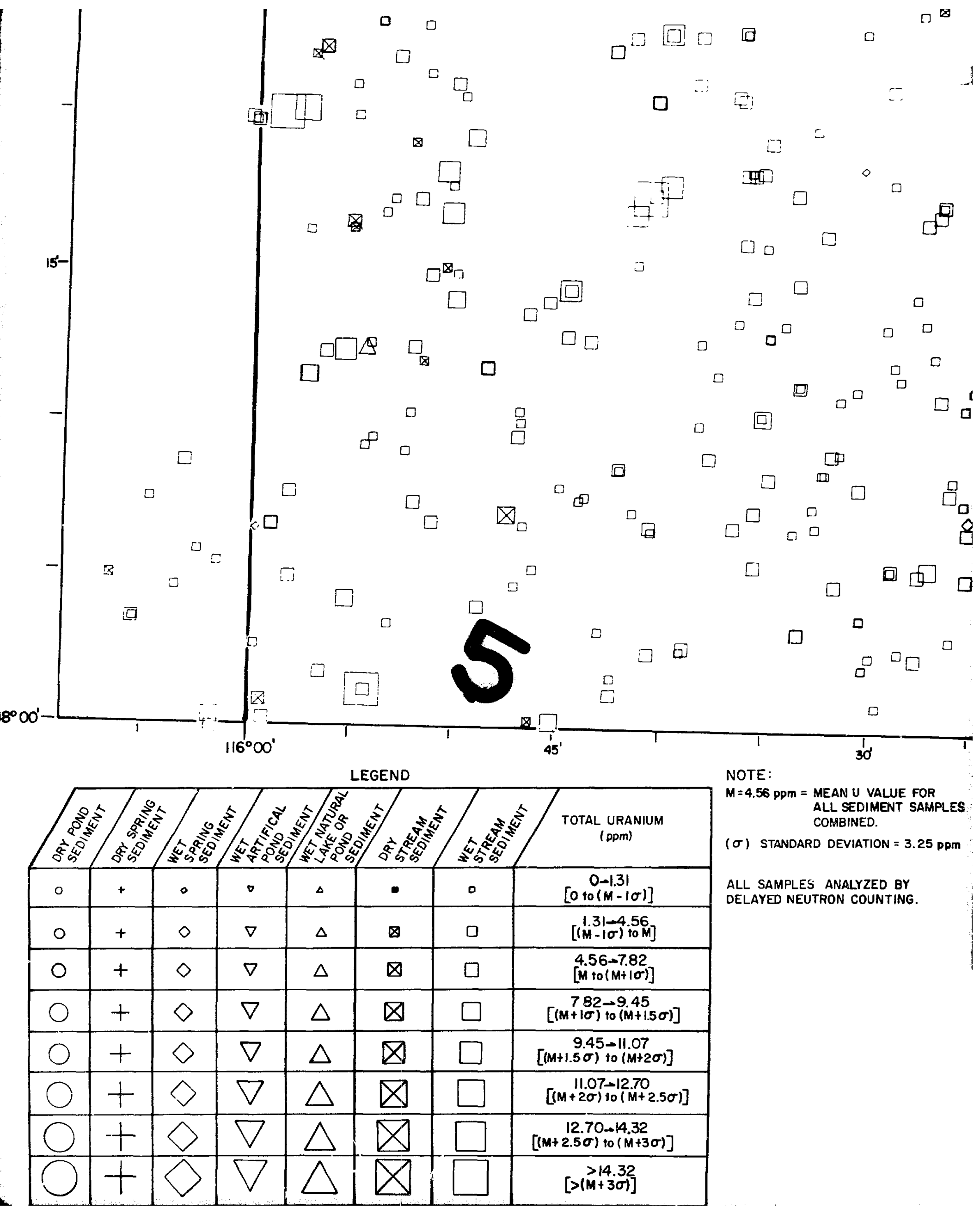




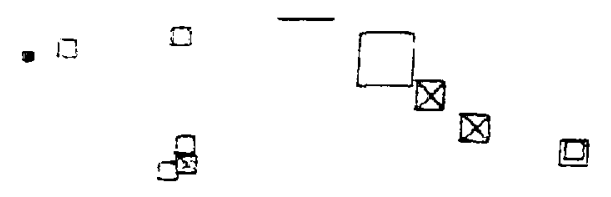

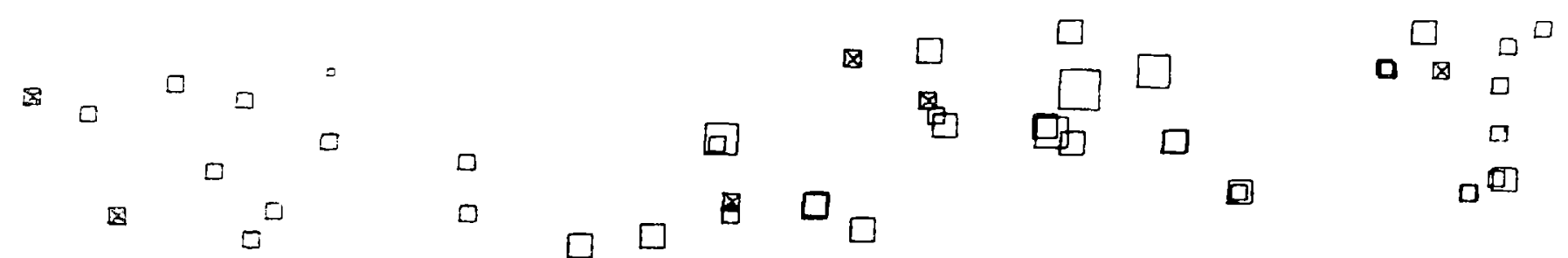

$\sigma^{9}$

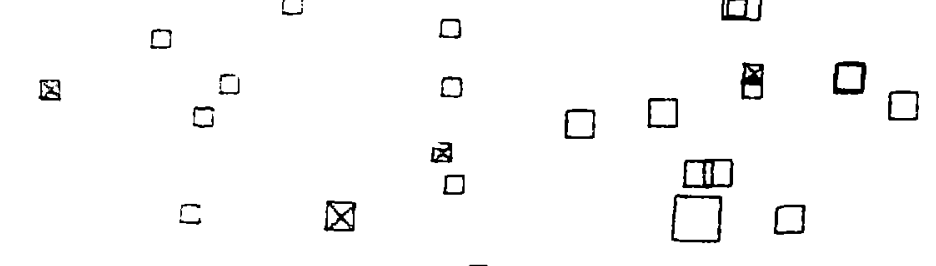

口

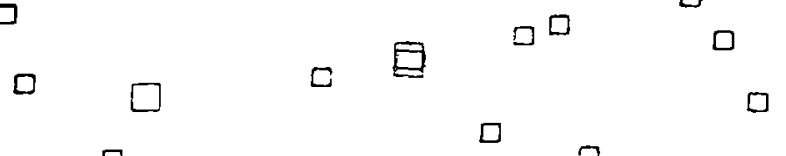

$\square a_{\square}^{\square} \quad \square \quad \square$

$\begin{array}{lll}a & 0 \\ 0 & 0 & 0 \\ 0 & 0\end{array}$

且
$\Delta$<smiles>O[AlH2]</smiles>

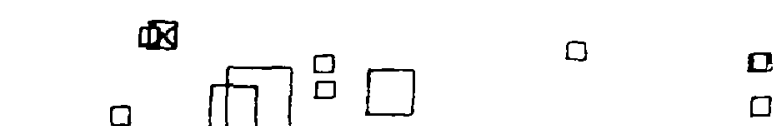<smiles>[Al]C1CCCC1C1CCCC1</smiles>

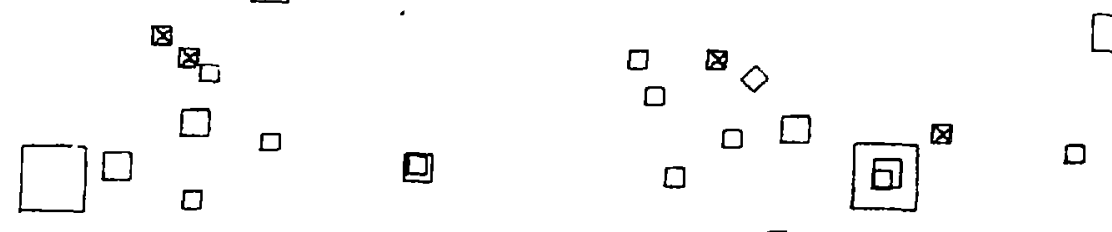

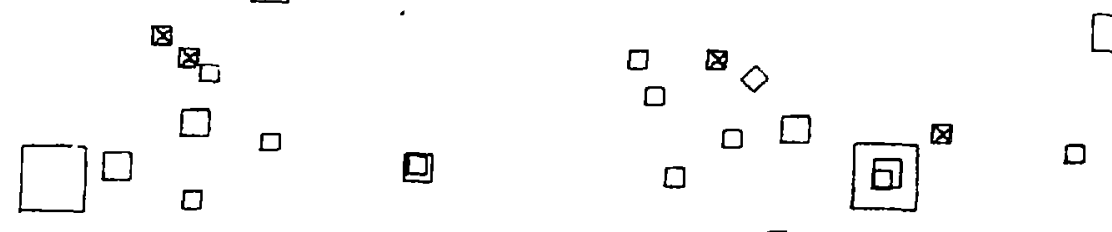

圆。口

$\square$ ᄃ. $\square$

$\Delta \square_{\square} \square_{\square}$

$\left[\begin{array}{lll}1 \\ 1\end{array}\right.$

$\square$

$\square$

$\square \square \square$

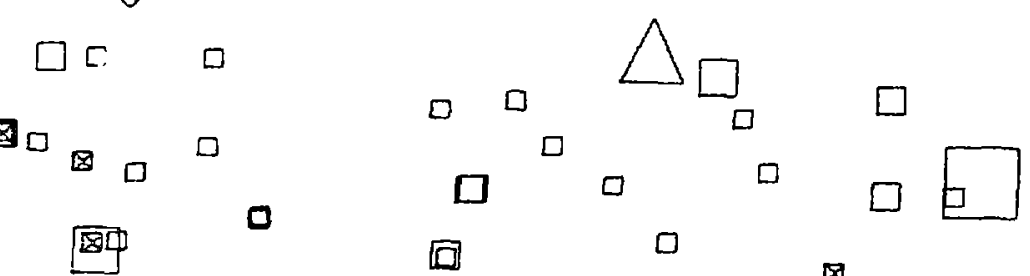

而然 


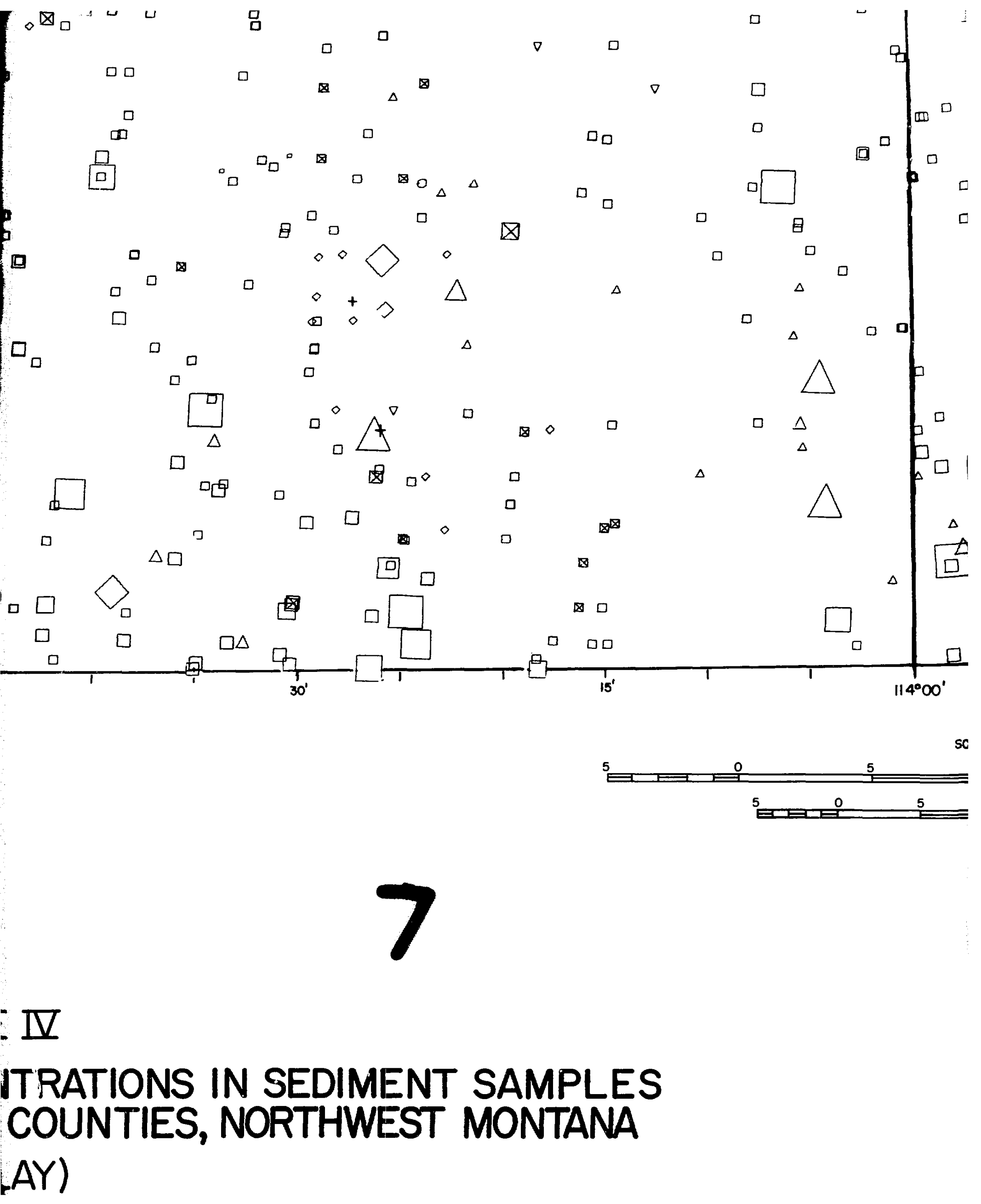


